\title{
Archaeological Testing of Four Sites on Camp Bowie, Brown County, Texas
}

Jason D. Weston

Raymond P. Mauldin

Center for Archeological Research, University of Texas at San Antonio

Follow this and additional works at: https://scholarworks.sfasu.edu/ita

Part of the American Material Culture Commons, Archaeological Anthropology Commons, Environmental Studies Commons, Other American Studies Commons, Other Arts and Humanities Commons, Other History of Art, Architecture, and Archaeology Commons, and the United States History Commons

Tell us how this article helped you.

This Article is brought to you for free and open access by the Center for Regional Heritage Research at SFA ScholarWorks. It has been accepted for inclusion in Index of Texas Archaeology: Open Access Gray Literature from the Lone Star State by an authorized editor of SFA ScholarWorks. For more information, please contact cdsscholarworks@sfasu.edu. 


\section{Archaeological Testing of Four Sites on Camp Bowie, Brown County, Texas}

Creative Commons License

(c) (i) (8)

This work is licensed under a Creative Commons Attribution-NonCommercial 4.0 International License 


\section{Archaeological Testing of Four Sites on Camp Bowie, Brown County, Texas}

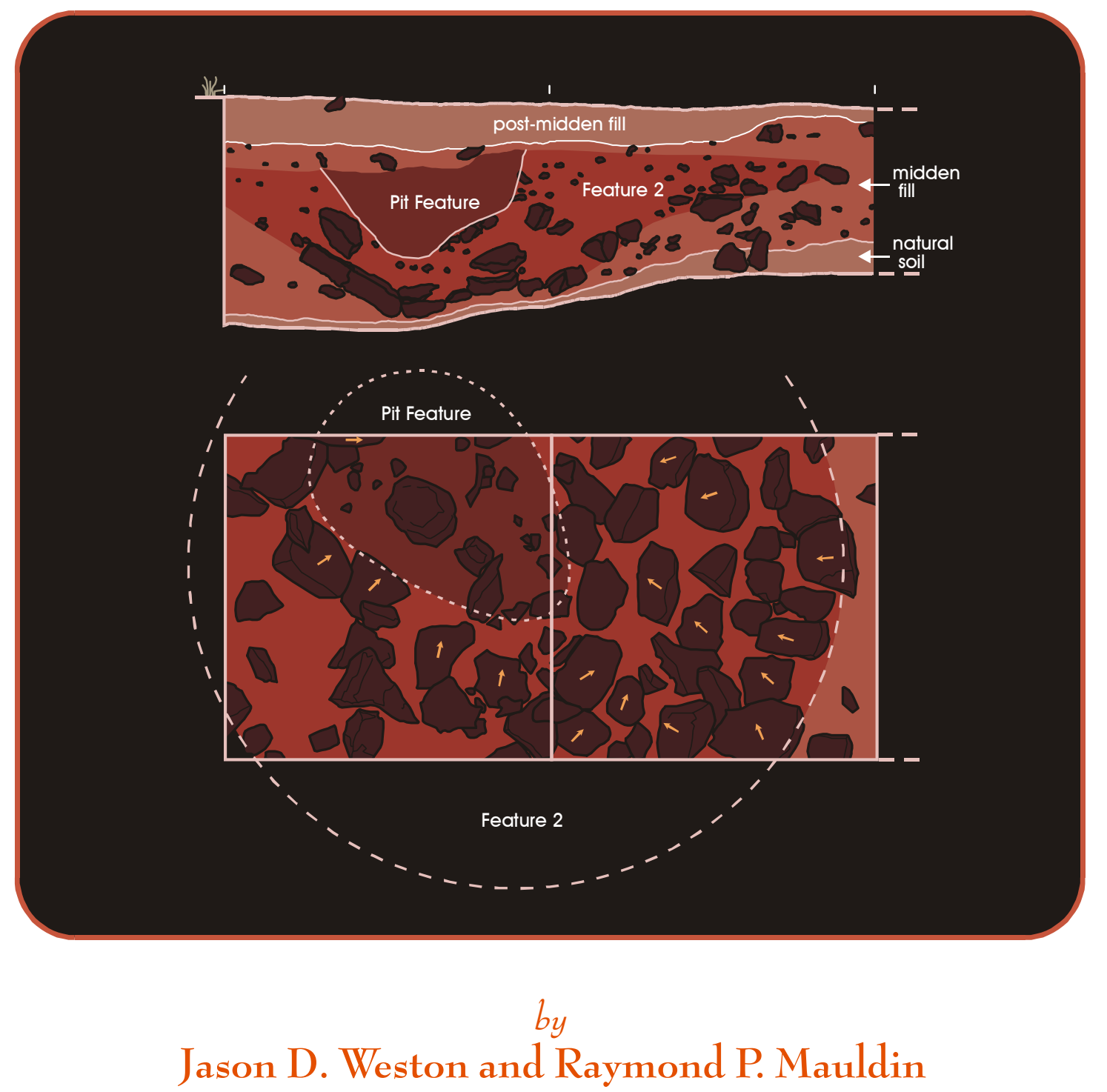

with Contributions by

J. Philip Dering, Russell D. Greaves, and Bryant Saner, Jr.

Adjutant General's Department of Texas Directorate of Facilities and Engineering Environmental Branch, Austin, Texas
Center for Archaeological Research The University of Texas at San Antonio Archaeological Survey Report, No. 335 


\title{
Archaeological Testing of Four Sites on Camp Bowie, Brown County, Texas
}

\author{
by \\ Jason D. Weston and Raymond P. Mauldin
}

with Contributions by

J. Philip Dering, Russell D. Greaves, and Bryant Saner, Jr.

Texas Antiquities Committee Permit No. 2926

Raymond P. Mauldin

Principal Investigator

Prepared for:

Adjutant General's Department of Texas

Directorate of Facilities and Engineering Environmental Branch, Austin, Texas
Prepared by:

Center for Archaeological Research

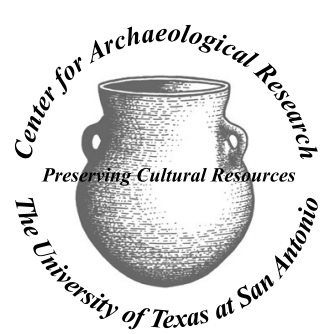
The University of Texas at San Antonio Archaeological Survey Report, No. 335 
A list of publications offered by the Center for Archaeological Research is available. Call (210) 458-4378; write to the Center for Archaeological Research, The University of Texas at San Antonio, 6900 N. Loop 1604 W., San Antonio, Texas 78249-0658; e-mail to car@lonestar.utsa.edu; or visit CAR's web site at http://car.utsa.edu. 


\section{Abstract}

In August of 2002, a crew from the Center for Archaeological Research (CAR) of The University of Texas at San Antonio tested four sites at Camp Bowie in Brown County Texas. Three sites, 41BR471, 41BR500, and 41BR522, were prehistoric and one site, 41BR392, had both historic and prehistoric components. This work was done under Texas Antiquities Permit No. 2926 for the Adjutant General's Department of Texas. Testing at these sites was done based on recommendations made for 41BR500 by Mauldin and Broehm (2001) and recommendations made for 41BR392, 41BR471 and 41BR522 by Greaves (2002).

Testing at 41BR392 centered on a prehistoric burned rock midden. Excavations took place in and around the midden. A few bifaces and a considerable amount of lithic debris were recovered. The size, location and density of burned rock within the midden were examined as a means of investigating the internal midden structure. Analysis of these data suggest that the midden represents an earth oven. Ethnobotanical recovery revealed the presence of geophytes. Radiocarbon dates place the feature within the Late Prehistoric period.

Testing at 41BR471 involved surface collection and excavation. Excavations confirmed that the site is deflated with sub-surface deposits being shallow and very minor. What remains of this site is a moderate to dense surface scatter of unmodified debitage and a few lithic cores.

Testing at 41BR500 centered on a suspected buried burned rock feature discovered during the spring 2001 survey. Excavations recovered unmodified lithic debitage, biface fragments and a scraper. Excavations in a separate area of the site where high debitage density was noted recovered a Nolan dart point dating to the Middle Archaic along with a number of bifaces and a considerable amount of unmodified lithic debitage. This additional testing uncovered a single charcoal stain, and radiocarbon dates place this feature within the Late Prehistoric period. Our analysis of the distribution of the diagnostic points, the distribution of debitage, and the radiocarbon date, suggest that much of this material is in secondary context.

Test excavations at 41BR522 showed very little debitage in or around the prehistoric burned rock midden. This small midden is nearly a perfect ring of burned rock surrounding a central hearth depression. Preservation was excellent for the recovery of both charred botanical remains and for examination of the midden structure. A Montell dart point, dating to the Late Archaic was recovered. As with 41BR392, the size, location and density of burned rock within the midden was examined as a means of investigating the internal midden structure. Analysis revealed the midden to be a central hearth/earth-oven type burned rock midden. Ethnobotanical recovery revealed the presence of geophytes. Radiocarbon dates place the feature within the Late Prehistoric period.

Based on the results of this testing, it is recommended that sites 41BR471 and 41BR500 are not eligible to the National Register of Historic Places and do not warrant status as State Archeological Landmarks. The sites have data that are of questionable integrity, and CAR's testing work has effectively exhausted any remaining research potential. Sites 41BR392 and 41BR522 are recommended as eligible to the National Register of Historic Places and do warrant status as State Archeological Landmarks. Both recommended sites have data with good integrity. In addition, both sites have charcoal present, and good recovery of ethnobotanical material. Data from these sites can be used to consider a variety of research questions that are significant for understanding the prehistory of the region. 


\section{Table of Contents}

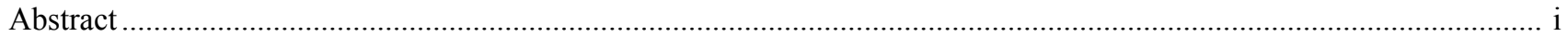

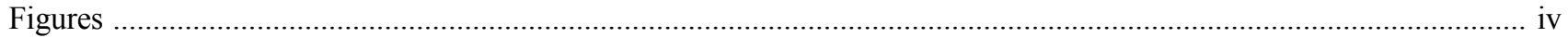

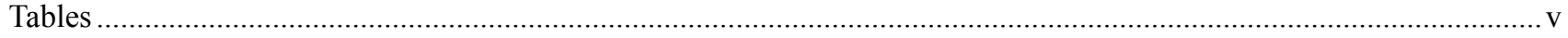

Acknowledgments ............................................................................................................................................ vi

Chapter 1: Introduction and Project Summary by Jason D. Weston

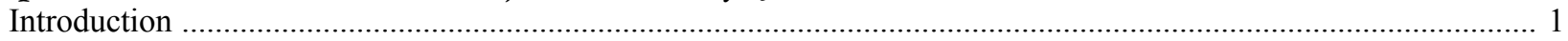

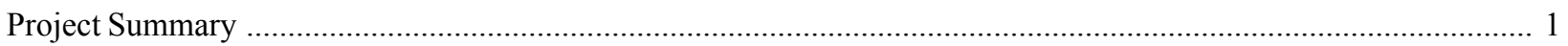

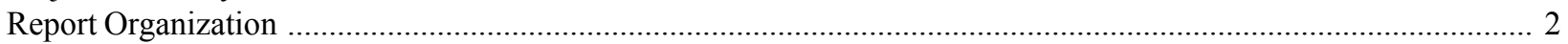

Chapter 2: Environmental Setting by Jason D. Weston

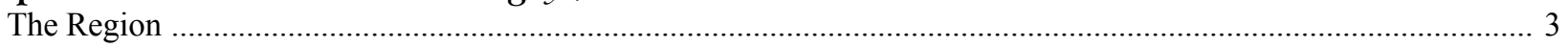

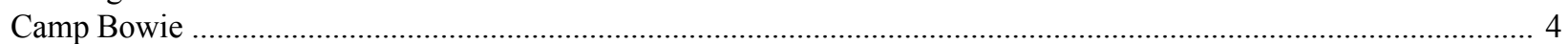

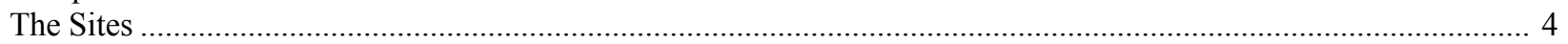

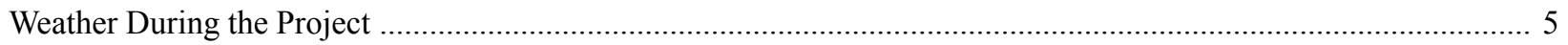

Chapter 3: Cultural Background and Previous Investigations by Jason D. Weston and

Raymond P. Mauldin

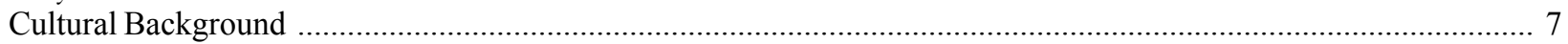

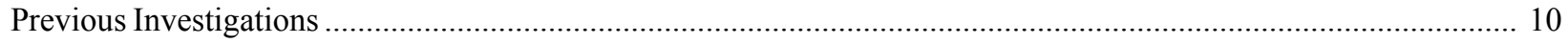

Chapter 4: Research Issues by Raymond P. Mauldin and Jason D. Weston

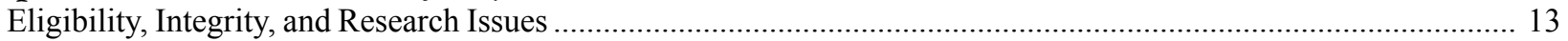

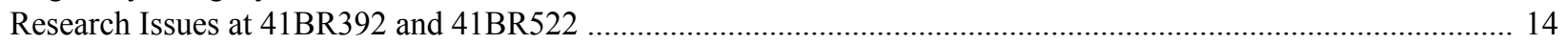

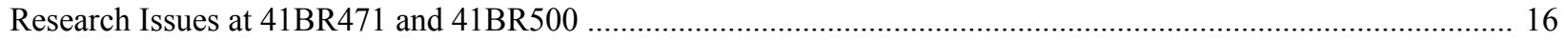

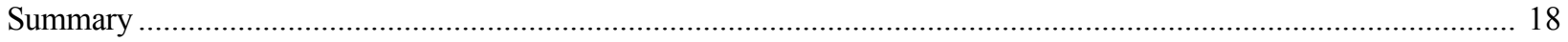

Chapter 5: Methodology and Theory by Jason D. Weston

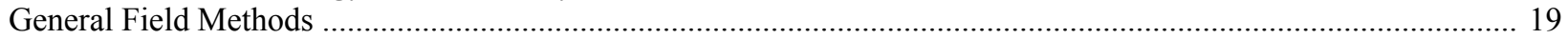

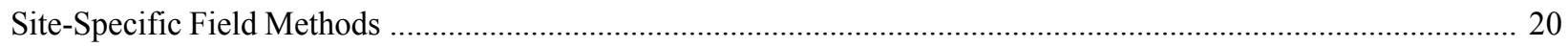

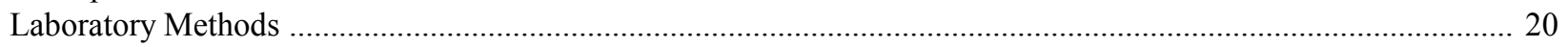

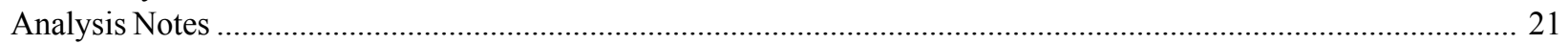

Chapter 6: Testing Results at Site 41BR392 by Jason D. Weston, Raymond P. Mauldin, and Bryant Saner

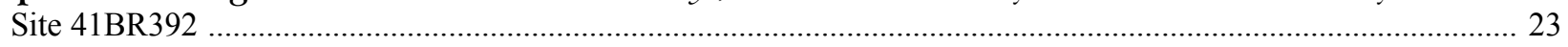

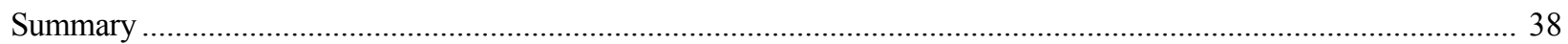

Chapter 7: Testing Results at Site 41BR47 1 by Jason D. Weston and Raymond P. Mauldin

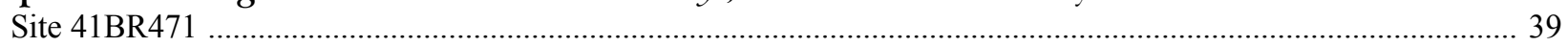

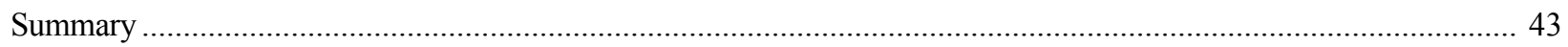

Chapter 8: Testing Results at Site 41BR500 by Jason D. Weston and Raymond P. Mauldin

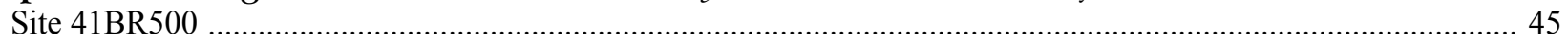

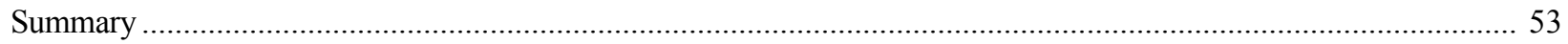

Chapter 9: Testing Results at Site 41BR522 by Jason D. Weston and Raymond P. Mauldin

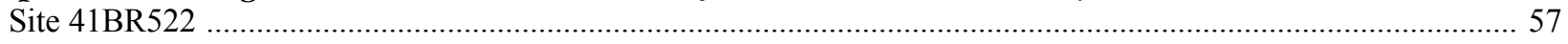

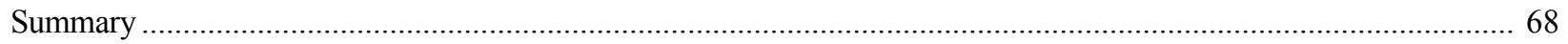

Chapter 10: Summary and Recommendations by Jason D. Weston and Raymond P. Mauldin

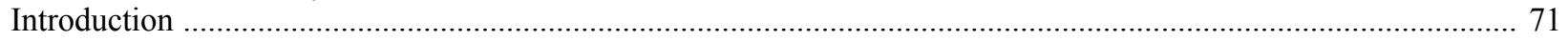

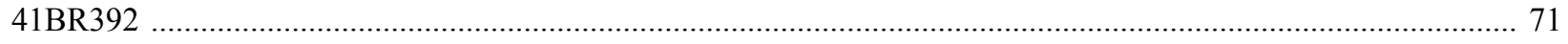

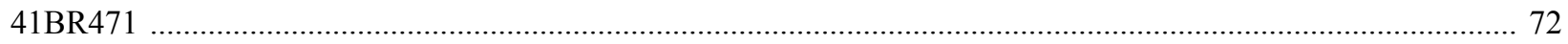

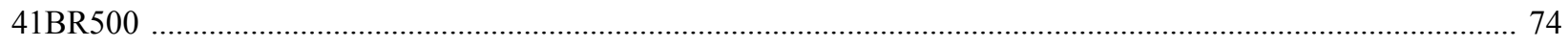

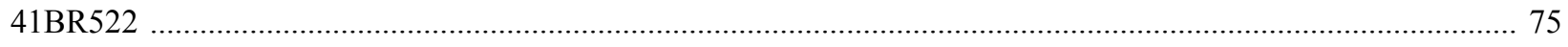

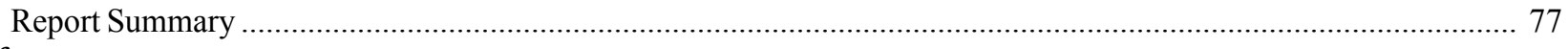

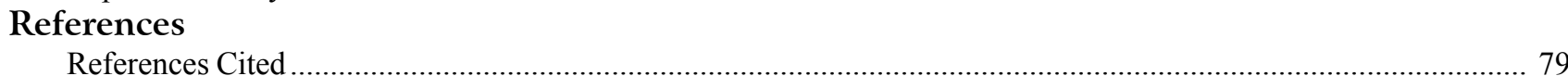


Appendix A: Radiocarbon Dating Results

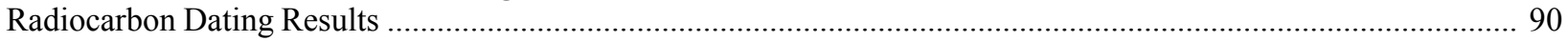

Appendix B: Ethnobotanical Remains by J. Philip Dering

Plant Remains from Sites 41BR392, 41BR500, and 41BR522 Located on Camp Bowie ......................................... 98

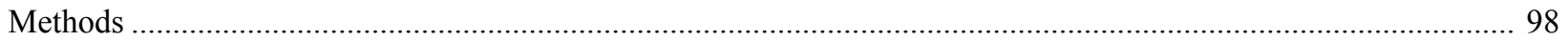

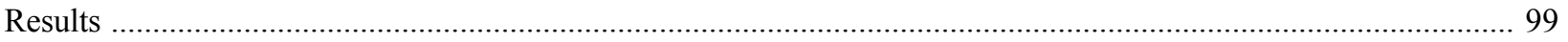

Ethnographic References to Geophytes on the Southern Plains Periphery .......................................................... 101

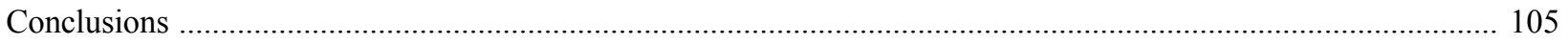

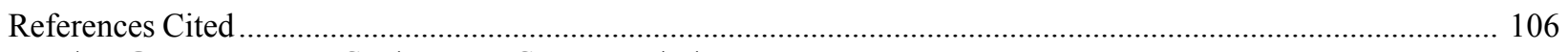

Appendix C: Magnetic Sediment Susceptibility by Raymond P. Mauldin

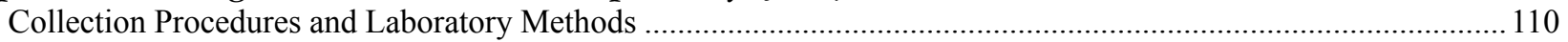

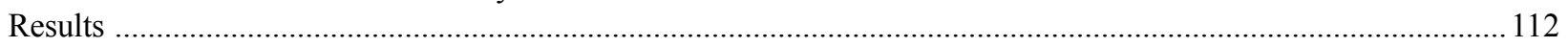

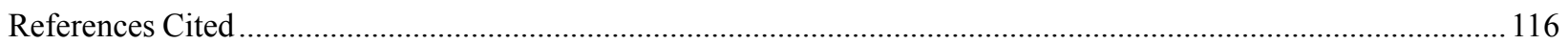

Appendix D: Geoarchaeological Investigations by Russell D. Greaves

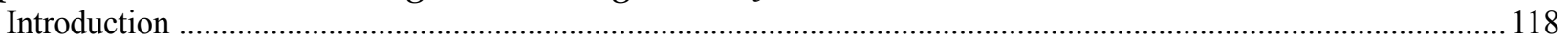

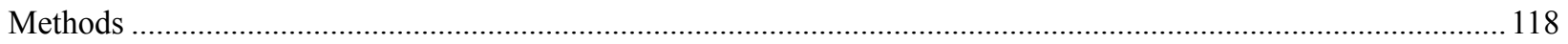

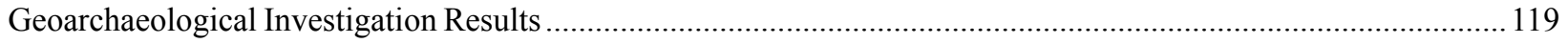

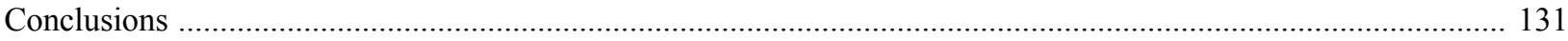

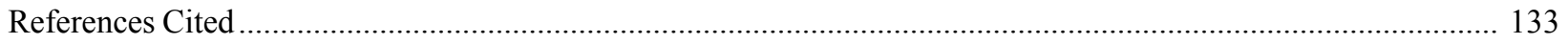




\section{Figures}

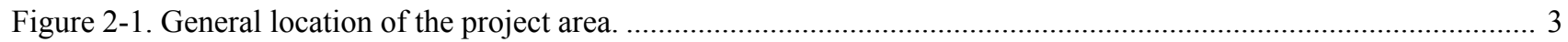

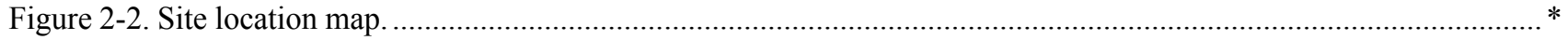

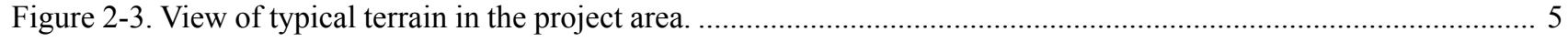

Figure 6-1. Site boundary and previous work at 41BR392. ................................................................................. 24

Figure 6-2. Shovel test and test unit locations for current work at 41BR392 .......................................................... 25

Figure 6-3. Percentages of chipped stone and mussel shell by level from shovel tests at 41BR392 _........................... 26

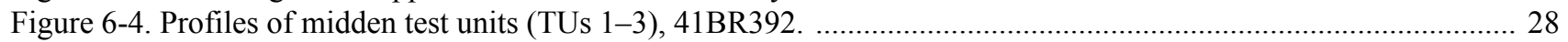

Figure 6-5. Percentages of chipped stone and mussel shell by level from non-midden test units at 41BR392................ 30

Figure 6-6. Distribution of mussel shell weight and chipped stone by level for Test Unit 3 at 41BR392 ....................... 31

Figure 6-7. Standardized number of rocks by level for Test Unit 3 at 41BR392. .................................................... 31

Figure 6-8. Standardized magnetic sediment susceptibility values for midden portion of Test Unit 3 at 41BR392. ........ 32

Figure 6-9. Earth oven model of midden formation. ............................................................................................... 33

Figure 6-10. Distribution of medium-sized rock groups by unit within the burned rock midden at 41BR392. ................ 34

Figure 6-11. Distribution of burned rock (6 inches or greater) by test unit for midden units at 41BR392 ..................... 34

Figure 6-12. Weight of small $(<1 \mathrm{inch})$ burned rock by test unit at 41BR392. ......................................................... 35

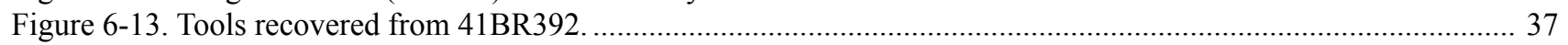

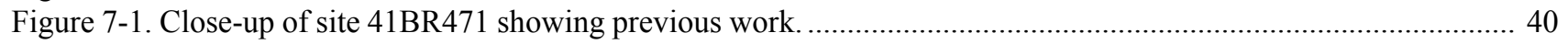

Figure 7-2. Locations of test units and collection areas at 41BR471. ................................................................... 41

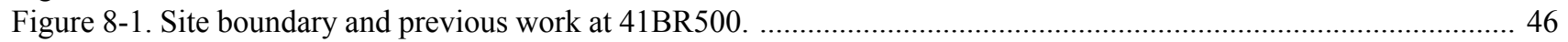

Figure 8-2. Locations of shovel tests and test units for current work at 41BR500 ..................................................... 47

Figure 8-3. Distribution of debitage from shovel tests at 41BR500....................................................................... 48

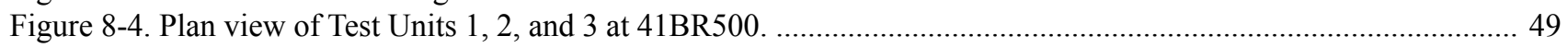

Figure 8-5. Magnetic sediment susceptibility values for Test Units 1, 2, and 3 at 41 BR500 ................................... 50

Figure 8-6. Distribution of chipped stone from Test Unit 4 at 41BR500 .............................................................. 50

Figure 8-7. Magnetic sediment susceptibility values from Test Unit 4 at 41BR500 ............................................... 51

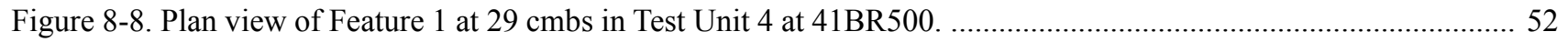

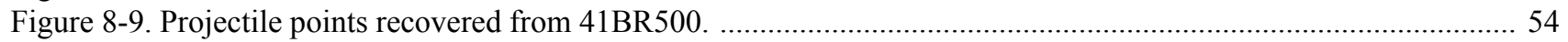

Figure 8-10. Selected tools recovered from 41BR500.

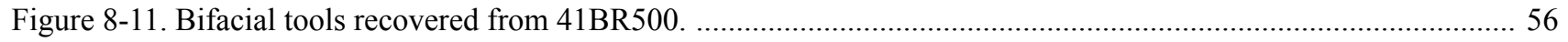

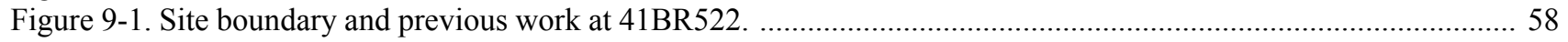

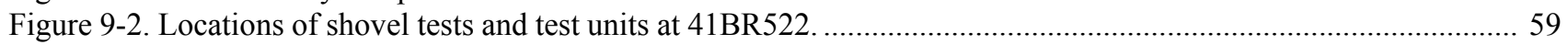

Figure 9-3. Percentages of chipped stone and mussel shell from shovel tests at 41BR522. .......................................... 60

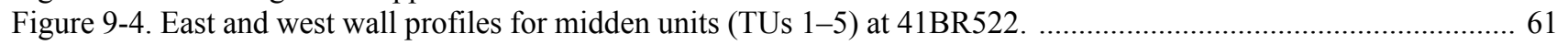

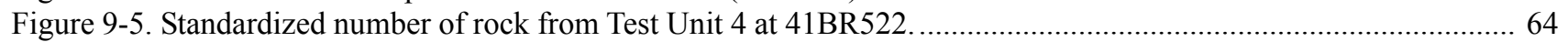

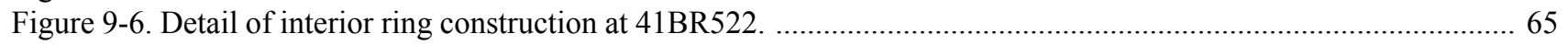

Figure 9-7. Fire-cracked rock size in midden units, 41BR522.

Figure 9-8. Number of fire-cracked rocks 6 inches or greater in size from midden units at 41BR522 .......................... 66

Figure 9-9. Weights of fire-cracked rocks less than 1 inch in size from midden units at 41BR522 ............................... 67

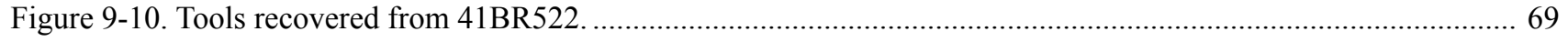

Figure 10-1. Proposed data recovery excavations on 41BR392 ......................................................................... 73

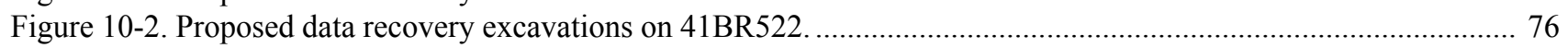

Figure D-1. Soil profile of Test Unit 4 (west wall) at 41BR392 .............................................................................. 119

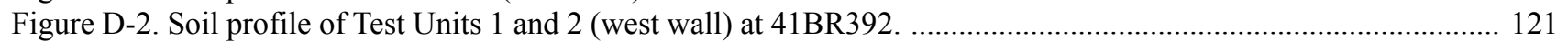

Figure D-3. Soil profile of Test Unit 3 (west wall) at 41BR392 ........................................................................ 123

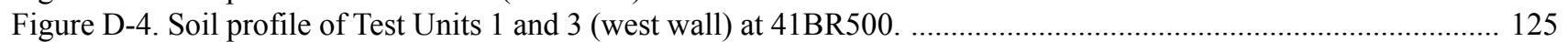

Figure D-5. Soil profile of Test Unit 4 (east wall) at 41BR500 ........................................................................ 125

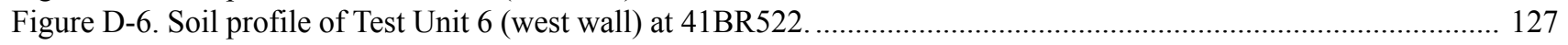

Figure D-7. Soil profile of Test Units 3 and 4 (west wall) at 41BR522. .................................................................. 129

* Figure 2-2 is located at the back of this report. 


\section{Tables}

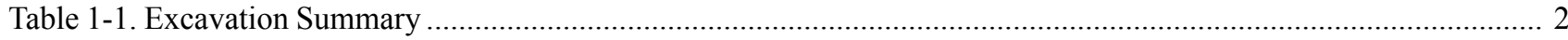

Table 6-1. Counts and Adjusted Residual Values for Cortex Patterns, 41BR392 and Remaining Sites .......................... 35

Table 6-2. Counts and Adjusted Residual Values for Flake Types, 41BR392 and Remaining Sites .............................. 36

Table 7-1. Counts and Adjusted Residual Values for Cortex Patterns, 41BR471 and Remaining Sites .......................... 42

Table 7-2. Counts and Adjusted Residual Values for Flake Types, 41BR471 and Remaining Sites ............................. 42

Table 8-1. Counts and Adjusted Residual Values for Cortex Patterns, 41BR500 and Remaining Sites .......................... 52

Table 8-2. Counts and Adjusted Residual Values for Flake Types, 41BR500 and Remaining Sites ............................... 53

Table 9-1. Counts and Adjusted Residual Values for Cortex Patterns, 41BR522 and Remaining Sites ........................... 68

Table 9-2. Counts and Adjusted Residual Values for Flake Types, 41BR522 and Remaining Sites ............................... 68

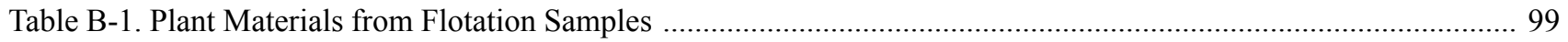

Table B-2. Macrobotanical (screen or point-collected) Samples ............................................................................ 100

Table B-3. Occurrence of Geophyte Remains from Archaeological Sites in Texas ................................................... 102

Table C-1. Magnetic Sediment Susceptibility Data for a Variety of Substances .......................................................... 111

Table C-2. Presence/absence of Cultural Material and Susceptibility Scores for Shovel Tests at 41BR473 ................... 112

Table C-3. Sediment Susceptibility Samples from 41BR392 ……....................................................................... 113

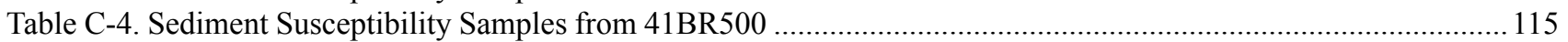

Table D-1. Soil Description for Test Unit 4 (West Wall Profile), 41BR392 ……...................................................... 120

Table D-2. Soil Description for Test Units 1 and 2 (West Wall Profile), 41BR392 ….................................................. 122

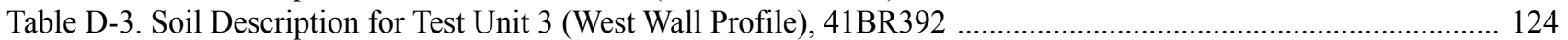

Table D-4. Soil Description for Test Units 1 and 3 (West Wall Profile), 41BR500 ................................................... 126

Table D-5. Soil Description for Test Unit 4 (East Wall Profile), 41BR500 ................................................................ 126

Table D-6. Soil Description for Test Unit 6 (West Wall Profile), 41BR522 ............................................................. 128

Table D-7. Soil Description for Test Units 3 and 4 (West Wall Profile), 41BR522 ................................................. 130 


\section{Acknowledgments}

First and foremost we would like to thank the field crew. Rebecca Galdeano, David Hafernik, Leonard Kemp, Bruce Moses, Jason Perez, Bryant Saner, Matthew Senn and Stacy Wagner all did great work. Thanks also to Sergeant Major M. Pilkington and his staff at the Camp Bowie HQ, and Shellie Sullo at Texas Army National Guard Environmental Resources Management Branch for their cooperation and assistance. Russell D. Greaves conducted and wrote the geomorphology research, and Bryant Saner contributed the analysis and write-up on the historic components recovered at 41BR392. Philip Dering provided the analysis of all botanical samples and Raymond Mauldin conducted the soil susceptibility analysis. Barbara Meissner identified the faunal remains. Laboratory processing, overseen by Marybeth Tomka, was conducted by Rebecca Galdeano, Carol Villalobos and Cindy Muñoz. The skilled drafting of the figures in this report was performed by Rick Young and Bruce Moses and the editing was done by Johanna Hunziker. 


\title{
Chapter 1: Introduction and Project Summary
}

\author{
Jason D. Weston
}

\section{Introduction}

In August 2002, crews from the Center for Archaeological Research of The University of Texas at San Antonio tested four prehistoric sites within Camp Bowie, Brown County Texas. This work was carried out under Texas Antiquities Permit No. 2926 and done in accordance with the proposal for eligibility testing approved by the Adjutant General's Department of Texas (AGTX). This was done to determine the eligibility of the four sites for inclusion to the National Register of Historic Places (NRHP) and qualification as State Archeological Landmarks (SALs).

Located in Brown County just south of Brownwood, Texas, on the Brownwood and Indian Creek USGS 7.5' quadrangles, Camp Bowie serves as a training area for the Texas Army National Guard. The facility is home to a variety of training activities; these include tank maneuvers, small arms training, and air-drops (Nature Conservancy of Texas 1996). Although originally over 100,000 acres in size, property liquidation since 1947, coupled with a number of other changes, has reduced the base to about 9,300 acres (Mauldin and Broehm 2001). Roughly $58 \%$ of the military base is state-owned, with the remaining 3,887 acres $\left(15.73 \mathrm{~km}^{2}\right)$ being owned by the federal government (Wormser and SulloPrewitt 2001). In addition to military training, a variety of other activities, including cattle and sheep grazing, hunting leases, the construction of stock ponds and earthen dams, and support facilities for livestock and hunting, have resulted in the extensive alteration of the natural vegetation (Environmental Assessment, Camp Bowie 1992; Wormser and Sullo-Prewitt 2001).

\section{Project Summary}

This project involved the archaeological testing of the prehistoric components on four sites - 41BR392, 41BR471, 41BR500, and 41BR522. The testing was designed to determine the eligibility of these sites for NRHP inclusion, as well as to make recommendations for possible designation of these sites as SALs.

Site 41BR392 has both prehistoric and historic components. At this site, testing focused on the prehistoric component centered on and around a burned rock midden. Twenty-five shovel tests were excavated around the midden. A total of five test units was excavated within and around the midden. Based on a high recovery in several shovel tests, a 1-x-1-m unit was placed to investigate that high-density area. A second off-midden 1-x-1-m unit was excavated to test deposits farther from the midden. Three 1-x-1-m units were placed in the midden. One was located on the talus ring and two adjoining units were placed in the central depression.

Site 41BR471 is characterized by surface concentrations of lithics. The testing of this site made use of six collection areas for controlled, surface collection. To test for buried deposits, two 1-x-1-m units were excavated in areas of the highest surface artifact density.

At 41BR500, the intact, undisturbed western edge of the site was tested using 10 shovel tests and four 1-x-1-m units. Three of the units were placed to examine a buried burned rock concentration noted during a previous survey (Mauldin and Broehm 2001). The fourth 1-x-1-m unit was placed next to the highest recovery shovel test to examine artifact density.

A prehistoric burned rock midden was the focus of our work at site 41BR522. Off-midden testing consisted of 21 shovel tests and one $1-\mathrm{x}-1-\mathrm{m}$ unit. On the midden, a total of five $1-x-1-m$ units was excavated contiguously from the central depression through the talus ring. This created a long profile for a thorough examination of the structure and central hearth feature within the midden. Table 1-1 summarizes the work performed at each site.

Sites 41BR392 and 41BR522 contain a variety of data sets, including recovery of both charcoal and ethnobotanical information from good contexts. Based on that recovery, we recommend that both these sites are eligible for NRHP nomination and for designations as SALs. As such, data recovery efforts to mitigate any impacts to these two locations as a result of training activities should be initiated. If mitigation is not conducted, then procedures to avoid impact to these two sites should be initiated. Conversely, we suggest that sites 41BR471 and 41BR500 lack significant data. Consequently, we do not recommend these two sites for nomination to the NRHP, nor do we recommend that they receive SAL designations. No additional work is recommended for sites 41BR471 and 41BR500. 


\section{Report Organization}

This draft report consists of 10 chapters and four appendices. After this introductory chapter, Chapter 2 provides an overview of the environment in the region. Chapter 3 summarizes the cultural background of the region and previous archaeological investigations conducted at Camp Bowie. Chapter 4 discusses research issues, while Chapter 5 outlines the field and laboratory procedures used during this project. Chapter 6 presents the results of testing at site 41BR392, the first of the two burned rock midden sites. Chapters 7 and 8 discuss the results of testing at sites 41BR471 and 41BR500, respectively - the two sites without burned rock middens. The results of testing at site 41BR522, the second burned rock midden site, are discussed in Chapter 9. Chapter 10 provides site assessments and recommendations for NRHP eligibility and SAL designation of the sites. Those recommendations are primarily based on our assessment of the research potential of these four sites using criteria outlined in Chapter 4 . The final chapter also provides a summary of the project.

The four appendices provide supporting data. Appendix A presents the radiocarbon results and calibrated dates from charcoal samples. Appendix B reports the results of research on the botanical specimens recovered during this project. Appendix $C$ summarizes the methods and results of research on magnetic sediment susceptibility. Appendix D presents the results of the geoarchaeological investigations.

The overall project map (Figure 2-2), which includes site locations, is not included in this report due to the sensitivity issues involved with archaeological sites. The map is provided in a pocket in the back of this report. If the map is not present, it may be obtained by writing to AGTX-EV, Cultural Resources, P.O. Box 5218, Austin TX 78763-5218.

Table 1-1. Excavation Summary

\begin{tabular}{|c|c|c|c|c|}
\hline Sites & $\begin{array}{c}\text { Number of } \\
\text { Shovel Tests }\end{array}$ & Min/Max Depth & $\begin{array}{c}\text { Number of } \\
\text { Test Units }\end{array}$ & Min/Max Depth \\
\hline 41BR392 & 25 & $40 / 50 \mathrm{cmbd}$ & 5 & $50 / 100 \mathrm{cmbd}$ \\
\hline 41BR471 & $* 0$ & $0 / 0 \mathrm{cmbd}$ & 2 & $40 / 58 \mathrm{cmbd}$ \\
\hline 41BR500 & 10 & $22 / 60 \mathrm{cmbd}$ & 4 & $30 / 70 \mathrm{cmbd}$ \\
\hline 41BR522 & 21 & $24 / 60 \mathrm{cmbd}$ & 6 & $50 / 72 \mathrm{cmbd}$ \\
\hline
\end{tabular}

*Six surface collection areas used in place of shovel tests. 


\title{
Chapter 2: $\quad$ Environmental Setting
}

\author{
Jason D. Weston
}

This chapter provides an introduction to the regional environment, along with details of Camp Bowie and the specific sites. Reviews of paleoenvironmental data, which are primarily available for areas to the south of the Camp Bowie area, can be found in Bousman (1998) and Johnson and Goode (1994). Additional information on these topics is available in Mauldin et al. (2003).
Characterized as subtropical sub-humid, the climate of the area is one of hot summers and mild winters. The average yearly temperature is $65^{\circ} \mathrm{F}$. The growing season averages about 239 days a year, with the average first freeze occurring on November 16 and the last freeze on March 21. Annual precipitation at Brownwood is approximately 26.1 inches $(66 \mathrm{~cm})$. The highest annual rainfall was recorded in 1959

\section{The Region}

Camp Bowie is located in north-central Texas in Brown County, just south of the town of Brownwood (Figure 2-1). The major hydrological feature in the roughly 615,000-acre county is Pecan Bayou, a river that enters the county from the northwest and exits in the southeast, into the Colorado River (Clower 1980). The Colorado marks the southern boundary of the county. Very shallow to deep, loamy and clayey soils cover the uplands of Brown County and deep, loamy and clayey soils cover the floodplains (Clower 1980).

Physiographically, the area is within the Rolling Plains subdivision, with the Edwards Plateau located just to the east and the Llano Uplift located to the south (see Gould 1975; Nance and Wermund 1993). The terrain of the Rolling Plains is characterized as gently sloping to hilly as a result of varying erosion of primarily Paleozoic rock formations (Fenneman 1931). The Edwards Plateau has a more rugged, stream-eroded topography, underlain by Cretaceous limestone. The Llano Uplift is essentially an eroded basin composed of Precambrian granitic and metamorphic rock (Swanson 1995).

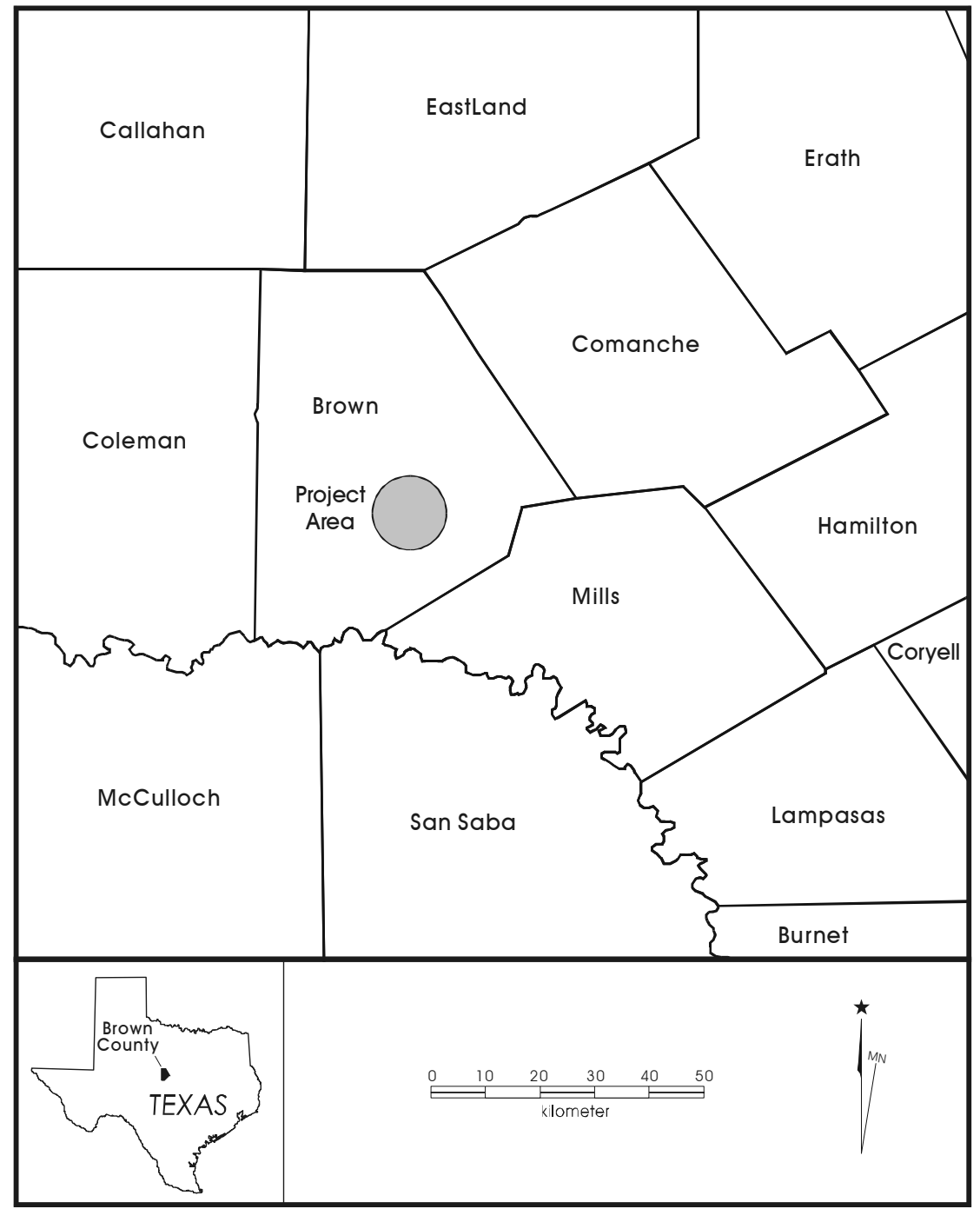

Figure 2-1. General location of the project area. 
when 42.3 inches $(107.4 \mathrm{~cm})$ of precipitation fell. The driest year on record was 1954 with only 12.8 inches $(32.5 \mathrm{~cm})$ of rainfall. Throughout the year, rainfall tends to be bimodal, with peaks in May and September. December and January are, on average, the driest months of the year (Bomar 1999; Nance and Wermund 1993).

The general vegetation is a Live Oak, Mesquite, Ashe Juniper Parkway dominating in the southwestern portion of the county, with an Oak, Mesquite, Juniper Parkway bracketing the Pecan Bayou drainage area. Silver bluestem and Texas wintergrass are present along the eastern edge of the county. Much of the county has been cleared for crops and grazing.

\section{Camp Bowie}

Camp Bowie covers an area of approximately 9,300 acres. Elevation within the camp ranges from 1,290 feet (393 m) above mean sea level (AMSL) to just over 1,590 feet (485 m) AMSL. A major topographic feature of the area is a northwest to southeast oriented high ridge of Cretaceous age deposits identified as the Travis Peak Formation (Wormser and SulloPrewitt 2001). This major sedimentary deposit includes limestone, sandstone, and conglomerate. Underlying Permian and Pennsylvanian formations, referred to as the Strawn Group, are exposed at various points on the landscape (Nance and Wermund 1993).

Soils of the Camp Bowie area are calcareous sandy loams, silty loams, and clay loams. Upland soils are thin and sandier, with low water-holding capacity. Lowland soils tend to be dominated by clay, with low permeability and high waterholding capacity (Nance and Wermund 1993; Wormser and Sullo-Prewitt 2001). Wormser and Sullo-Prewitt (2001) classified the USDA soil units at Camp Bowie into three general groups designed to monitor their potential to contain buried, intact cultural deposits. The tripartite distinction was based on their evaluation of the soil age and formation history. Essentially, the likelihood of buried, intact sites is greater in the lowlands where soil is likely to be deposited from eroding ridge tops, covering sites in the lowlands. On the ridge tops, the chances of buried sites is reduced or nonexistent due to the erosional factor. Site-specific soil descriptions are discussed in Appendix D.

Cutting through the soils in Camp Bowie are seasonally active streams. In the generally dry environment of the area, even the main creek channels (Lewis Creek and Devils River) are quite small as they flow to Pecan Bayou in the north. More detailed information on climate, geology and soils of the area can be found in Gould (1975), Mauldin et al. (2003), Nance and Wermund (1993), and Wormser and Sullo-Prewitt (2001).

A biological inventory of Camp Bowie, prepared by Texas Parks and Wildlife (TPW 1994), provides an extended discussion of both plants and animals observed, or expected to be present, at Camp Bowie. In short, the plant communities appear to have been altered by a variety of land uses, including attempts to increase grass cover for livestock. Much of the area can be characterized as a Live OakMesquite-Ash Juniper community. Major tree and shrub species present include a variety of oaks, ashe juniper, mesquite, pecan, cedar elm, American elm, lotebush, and whitebush. Grasses, including Texas grama and buffalo grass, with a variety of cacti are also present (Environmental Assessment, Camp Bowie 1992; Nature Conservancy of Texas 1996; TPW 1994). While the above-mentioned biological inventory provides a complete list of the fauna at Camp Bowie, several species are present in noticeable abundance. Fauna seen each day during the fieldwork, aside from the implacable, ever-present domestic cattle (Bos taurus), were white-tailed deer (Odocoileus virginianus; Davis 1974) and a species of tiny green-bodied, reddishtailed lizard, unidentifiable by the archaeologists present in the field. Turkey (Meleagris gallopavo), Roadrunners (Geococcyx californianus; Robins et al. 1983) and very large Yellow Garden Spiders (Arigope aurantia; Jackman 1997) were seen almost daily.

\section{The Sites}

All four sites tested on this project (41BR392, 41BR471, 41BR500 and 41BR522) are lowland, and several are located near the northwest to southeast running high ridge (Figure 2-2, located at back of report). Figure 2-3 shows a typical view of Camp Bowie in this area. The unnamed drainages near 41BR392, 41BR471 and 41BR522 all flow into Devils River, while 41BR500 sits just off of Lewis Creek. Both Lewis Creek and Devils River are intermittent streams draining into Pecan Bayou.

The drainage next to 41BR392 passes between the site and a man-made pond $15 \mathrm{~m}$ to the west. The ground is level, covered with a carpet of grasses interspersed with a thin stand of mesquite trees and an occasional oak. Overall, surface visibility ranged from 0 to $60 \%$. The cactus and whitebush present are largely confined to the surface of the 


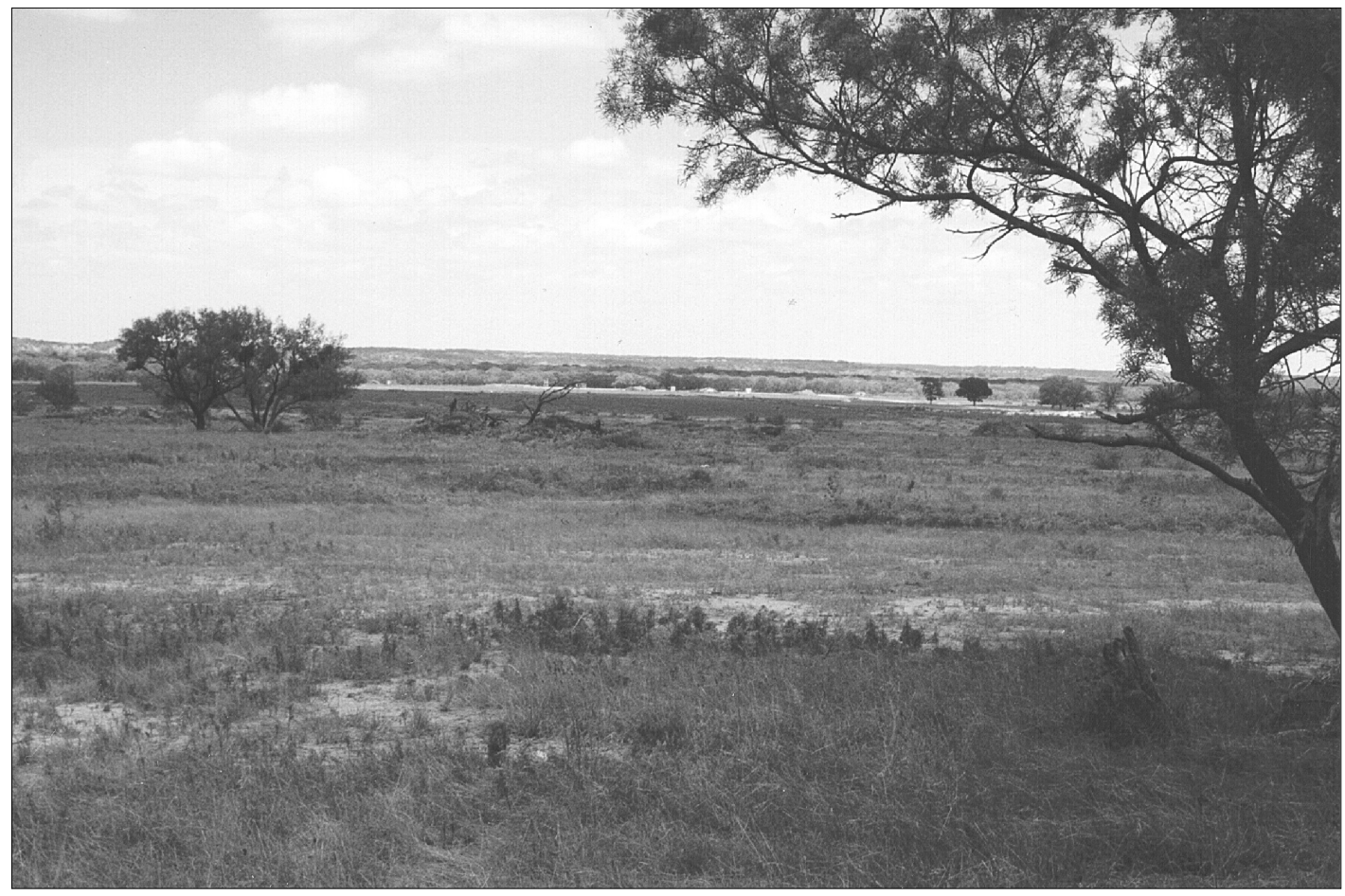

Figure 2-3. View of typical terrain in the project area.

burned rock midden at the north end of the site. Sitting at the receiving end of a firing range, the site is littered with spent projectile rounds, but the midden seems unharmed. The rounds consist of .30-caliber copper alloy bullets, still untarnished, and large, solid aluminum rounds labeled $C T G$ 40mm Practice M385E4.

At site 41BR471, the ground surface slopes gently to the north and west. Grasses are sparse leaving patches of exposed earth allowing for $75 \%$ to $100 \%$ surface visibility. Surrounding the open area of the site is a mix of juniper and mesquite with cactus, lotebush, whitebush and grasses making up the understory vegetation. A man-made pond lies $20 \mathrm{~m}$ to the west of the site.

Site 41BR522 sits abutting the ridge base and is covered with whitebush and cactus huddled next to the mesquite trees growing on and around the burned rock midden. While just 10-15 $\mathrm{m}$ away, thick grasses dominate the undergrowth obscuring the surface from view, the area of the midden has roughly $60 \%$ surface visibility.
Site 41BR500 is separated from the other sites by a northnortheast running ridge jutting out like a finger from the main line of high ridges. Most of 41BR500 is in a heavily plowed field, now gone to pasture, which has been modified by berms. The area tested during this project is on the extreme western edge of the site and does not seem to have been disturbed by plowing or other earth working. Most of this area is covered in oak and a few mesquite trees with an understory of grasses. Mesquite, lotebush and whitebush grow dense near the margins abutting the disturbed area.

\section{Weather During the Project}

The environmental/weather conditions at Camp Bowie during the time of this project $\left(14^{\text {th }}-29^{\text {th }}\right.$ of August 2002) were dry, sunny, and hot with a mild breeze making most days manageable if not comfortable. In short, the weather in no way interfered with excavations. 



\title{
Chapter 3: Cultural Background and Previous Investigations
}

\author{
Jason D. Weston and Raymond P. Mauldin
}

Brown County/Camp Bowie is located in the northwest corner of the Central Texas archaeological region (Collins 1995; Turner and Hester 1999). The major cultural periods identified in this region, and specifically Brown County, are described in this chapter along with a summary of previous archaeological research conducted at Camp Bowie. Changes in technological patterns are the prime movers in the division of the past into archaeological regions and the major cultural periods described below. These divisions serve to organize our knowledge of the past. Additional information on the Central Texas archaeological region may be found in Collins (1995) and Johnson and Goode (1994).

\section{Cultural Background}

\section{Paleoindian}

The Paleoindian period, beginning around 12,500 years ago, marks the first appearance of humans in the New World, although the exact date for their arrival is unclear. Traditionally, the Paleoindian period is first marked by the appearance of Clovis points in North America, which are later replaced by Folsom points. The later part of the Paleoindian period $(10,000-8000 \mathrm{BP})$ is characterized by a variety of dart point types, including Plainview, Dalton, Angostura, Scottsbluff, and Golondrina (Black 1989a, 1989b). The geographic range of these various projectile point types through North America is widespread.

Artifacts from this period, particularly projectile points, often occur only as isolated finds. Known site types include campsites, lithic procurement, kill, cache, ritual and burial sites (Collins 1995). Early Paleoindian peoples have generally been conceptualized as hunter-gatherers ranging over wide areas in pursuit of now-extinct megafauna, such as mammoth and Bison antiquus. This view of Paleoindian peoples, much like the dating of this period, is now being reassessed (Collins 1995). While certainly exploiting Late Pleistocene megafauna, these peoples are perhaps better characterized as more generalized hunter-gatherers. Certainly by the later Paleoindian time frame, after the extinction of the megafauna, the hunting aspect of subsistence shifted to exploitation of herbivores like deer and the smaller, modern bison (Bison bison).

\section{Archaic}

The Archaic period can be broadly defined by changes in projectile point types, an increase in the number and types of sites (including burned rock hearths and middens), and by an increase in the variety of artifact styles, with many artifacts having more limited geographical distribution relative to the Paleoindian period. While a number of finer subdivisions exist for the Archaic (e.g., Prewitt 1981; Weir 1976), this period can be broadly divided into the Early, Middle, and Late Archaic.

\section{Early Archaic}

Collins (1995) dates the Early Archaic from 8800 to 6000 BP in Central Texas, with three divisions based on projectile point types, while Hester (1995) identifies the Early Archaic with Early Corner Notched and Early Basal Notched dart points roughly dating between 7950 and 4450 BP. The Early Archaic on the Southern Great Plains is approximated at 8000-5000 BP (Hofman 1989), although Johnson and Holliday (1986) offer more fine-grained dates of 8500-6400 BP for the Llano Estacado, based on data from the Lubbock Lake site. The extinction of large herds of megafauna and the changing climate at the beginning of the Holocene appears to have stimulated a behavioral change in the Prehistoric inhabitants of Texas. While the basic huntergatherer adaptation probably remained intact, an economic shift away from big game hunting was necessary. In general, more intensive exploitation of local resources in Central Texas, such as deer, fish and plants, is indicated by greater densities of ground stone artifacts, fire-cracked rock cooking features, and more specialized tools such as Clear Fork gouges and Guadalupe bifaces (Turner and Hester 1999).

Weir (1976) speculates that Early Archaic groups were small and highly mobile, an inference based on the fact that Early Archaic sites are thinly distributed and that diagnostic projectile point types are seen across a wide area, including most of Texas and northern Mexico. Hurt (1980) suggests that the decline in the number of bison on the plains forced the inhabitants to broaden their diets and pursue plants and animals which would produce the same amount of calories and protein with the same or slightly more effort expended. Story (1985) suggests that population densities, at least in 
some regions, were low during this period, and that groups consisted of related individuals in small bands with "few constraints on their mobility" (Story 1985).

\section{Middle Archaic}

Collins (1995) defines this intermediate interval of the Archaic as lasting from about $6000 \mathrm{BP}$ to $4000 \mathrm{BP}$ in Central Texas, but Hester (1995) suggests that the period between 4450 and 2350 BP more correctly reflects the Middle Archaic in South Texas. The Southern Plains Middle Archaic complex, as derived from changes in climate and subsistence, is recognized generally as the period between $5000 \mathrm{BP}$ and $3000 \mathrm{BP}$ (Hofman 1989), and more specifically as 6400-4500 BP on the Llano Estacado (Johnson and Holliday 1986). The Middle Archaic appears to have been a time of increased population, based on the large number of sites from this period in South and Central Texas (Story 1985; Weir 1976). The reasons for this increase are not known, but the decreased severity of a very dry period (Altithermal) during the Early Archaic is often seen as the main cause (Story 1985).

A wide variation in projectile point styles at the Jonas Terrace site in Medina County suggests "a time of ethnic and cultural variety, as well as group movement and immigration" (Johnson 1995). Hurt (1980) postulates that the quantity of diversified game animals on the Southern Great Plains decreased, and led to an intensified, less broad diet. On the South Texas Plain, exploitation of widely scattered, yearround resources such as prickly pear continued (Campbell and Campbell 1981), as did hunting deer and rabbit. However, a shift to concentrated, seasonal nut harvests in the riverine environments of the Balcones Escarpment may have occurred (Black 1989a, 1989b). Weir (1976) believes that an expansion of oak on the Edwards Plateau and Balcones Escarpment led to intensive plant gathering and acorn processing. He also believes that the widely scattered bands prevalent in the Early Archaic began to coalesce, at least during the acorn-gathering season, into larger groups who shared the intensive work of gathering and processing the acorn harvest (Weir 1976). Many researchers believe burned rock middens, one of the principal feature types investigated on the current project, are a result of this endeavor (Creel 1986; Prewitt 1991; Weir 1976). Other investigators doubt this conclusion (Black et al. 1997; Goode 1991) and the exact processes that formed the burned rock middens are still a matter of controversy (see Hester 1991; Leach and Bousman 2001).
The common presence of deer remains in some burned rock middens encourages the view that deer processing took place at burned rock midden sites (Black and McGraw 1985; Nickels et al. 2001; Weir 1976). Bison bone is encountered in archaeological sites in Central and South Texas, at least occasionally, during all but the earliest part of the Middle Archaic (Dillehay 1974). There has been a tendency to equate presence of burned rock middens with absence of bison (Prewitt 1981); however, examinations of several recent faunal reports show that after about 4500 BP bison and burned rock middens are contemporaneous, though not at the same sites, at least in the southern Edwards Plateau and northern South Texas Plain (Meissner 1993).

\section{Late Archaic}

Collins (1995) dates the final interval of the Archaic in Central Texas to approximately $4000-800$ BP. Hester believes the Late Archaic in South Texas may be better defined as between 2350-1250 BP, while Hofman's (1989) synthesis of these data places the Late Archaic on the Southern Plains at 3000-2000 BP, and possibly later. Johnson and Holliday (1986) specify 4500-2000 BP as the Late Archaic period on the Llano Estacado. Some researchers believe populations increased throughout the Late Archaic (Prewitt 1985), while others feel populations remained the same or fell during this period (Black 1989a). Prewitt (1981) asserts that the accumulation of burned rock middens nearly ceased during the course of this period; however, excavations at a number of sites (e.g., Johnson 1995; Houk and Lohse 1993) provide evidence that large cooking features up to 15 meters in diameter were still very much in use. Subsistence assumably became less specialized during the Late Archaic (Black 1989a). Hurt (1980) asserts that bison began returning to the Southern Great Plains area, and we see an increase in intensive processing of bison, as well as freshwater mussels during the Late Archaic. However, by about $1450 \mathrm{BP}$, bison had again disappeared (Dillehay 1974).

The proliferation of distinguishable human cemeteries has been attributed to this period, with the earliest occurrences dating to the South Texas Middle Archaic (Hester 1995). At Loma Sandia, the cemeteries date between about 2550 and 2750 BP (Taylor and Highley 1995). Story (1985) believes the presence of cemeteries at sites such as Ernest Witte (Hall 1981), Hitzfelder Cave (Givens 1968), and Olmos Dam (Lukowski 1988) indicates that Late Archaic populations in Central and South Texas were increasing and becoming more territorial. 
Although inhabitants of the South Texas Plain near Brownsville and Rockport had begun to make pottery by about $1750 \mathrm{BP}$, the northern part of the plain remained "preceramic" until 1,000 years later (Story 1985). Late Archaic points tend to be much smaller than Middle Archaic points. The most common are Ensor and Frio types (Turner and Hester 1999), both of which are short, triangular points with side notches. The Frio point type also has a notched base (Turner and Hester 1999).

A late subperiod or interval of the Late Archaic is frequently referred to as the Terminal Archaic or Transitional Archaic. Weir (1976) defines the Terminal Archaic as 1650-1150 BP, while Turner and Hester (1999) cite data placing the Transitional Archaic at 2250-1250 BP. Although Hester may lump current data into a Late Archaic period, he cautions that more evidence will likely result in what may be termed a "Terminal Archaic" period during the latter part of the Late Archaic in South Texas. This Terminal Archaic period is represented by diagnostics such as Ensor, Frio, and Matamoros points which appear to overlap the Late Archaic and the subsequent Late Prehistoric period (Hester 1995). Weir (1976) believes this marked a transition period to localized area sites, a disappearance of burned rock middens and bison, and a reappearance of highly mobile hunters and gatherers. Others (Black and McGraw 1985; Skelton 1977) argue that in some locations burned rock middens did not disappear and sites were more intensely occupied during the Transitional Archaic period. During the Early Neo-Indian period (early Late Prehistoric) on the Southern Great Plains (circa 950-1450 BP), Hurt (1980) presents evidence for a decrease in bison processing. This decrease is consistent with Dillehay's (1974) contention that there were fewer bison available in the area due to climatic changes.

\section{Late Prehistoric}

The term Late Prehistoric is commonly used to designate the period following the Late Archaic in Central and South Texas. Collins (1995) recognizes that the commonly used date of 1200 BP for the end of the Archaic and beginning of the Late Prehistoric in Central Texas is arbitrary, and Hester (1995) acknowledges the problematic issue of selected tools appearing at both Late Archaic and Late Prehistoric sites. A series of distinctive traits mark the shift from the Archaic to the Late Prehistoric, including the technological shift to the bow and arrow and the introduction of pottery to Central Texas and the northern South Texas Plain (Black 1989a; Story 1985). Two complexes following the Late Archaic in the Southern Great Plains region are the Plains Woodland from about 2000-1150 BP, and the Plains Village from 1150-450 BP (Hofman 1989). Most researchers agree the early Late Prehistoric period was a time of population decrease (Black 1989a). Though small burned rock middens associated with Scallorn and Edwards points have been found (Goode 1991; Houk and Lohse 1993), most researchers argue that they are rare. Settlement in rockshelters is increasingly common, with occupations in shelters such as Scorpion Cave in Medina County (Highley et al. 1978) and Classen Rockshelter in northern Bexar County noted (Fox and Fox 1967; Skinner 1981). Remains from cemeteries from this period often reveal evidence of conflict (Black 1989a).

Beginning rather abruptly at about $650 \mathrm{BP}$, a shift in technology occurred. This shift is characterized by the appearance of Perdiz arrow points, alternately beveled bifaces, the first ceramics in Central Texas (bone-tempered plainwares), and the introduction of blade technology (Black 1989a; Huebner 1991). Prewitt (1985) suggests this technology encroached from north-central Texas. Patterson (1988), however, notes the Perdiz point was first seen in southeast Texas by about $1350 \mathrm{BP}$, and was introduced to the west some 600-700 years later. Hester (1995) recognizes this phase as the "best documented Late Prehistoric pattern" throughout South Texas, with dates ranging from about 650/ $700 \mathrm{BP}$ to $300 / 350 \mathrm{BP}$.

Steele and Assad Hunter (1986) argue for the occurrence of a distinct change in diet between the Late Archaic and the Late Prehistoric components at two sites in the Choke Canyon Reservoir area in South Texas. Analysis of the number of identified specimens (NISP) shows a marked increase in artiodactyl elements during the late Late Prehistoric, an increase largely due to the addition of bison to the "menu" (Steele and Assad Hunter 1986). Huebner (1991) suggests that the sudden return of bison to South and Central Texas resulted from a more xeric climate in the plains north of Texas, and increased grass in the CrossTimbers and Post Oak Savannah in north-central Texas, forming a "bison corridor" into the South Texas Plain along the eastern edge of the Edwards Plateau. Sites from this period frequently have associated bison (Black 1986; Black and McGraw 1985; Prewitt 1974).

\section{Historic}

In North America, the Historic period can be seen as having two major divisions. First is the Colonial period, a time of rule and colonization by Europeans from the 1500s to the 
late 1700 s in the east and early 1800 s in the west and south of North America (ending with the expulsion of Spain from Mexico). The second is the more recent historic from the end of the Colonial period up to 50 years ago. Thus far, the post-Colonial historic stands archaeologically as a single span of time that encompasses everything from the Texas Revolution through the advent of television.

The Historic period anywhere in the world begins with the presence of a written record. In North America this is synonymous with the beginning of European immigration/ conquest. The impact of this immigration for the Brown County region was erratic to nonexistent for several centuries after European arrival in the Americas. In the A.D. 1530s Cabeza de Vaca passed far to the south (Chipman 1992) and in A.D. 1541 Coronado passed far to the north (de Castañeda et al. 1990) of what is now Brown County. This area did not become a part of historically recorded events until the early 1700s when Spain came into conflict with the Lipan Apache. As time went on, the governments of Spain, Mexico, and the Republic of Texas each had their turn at sporadic, often violent contact with native groups living in the region (Wormser and Sullo-Prewitt 2001). For the purposes of archaeological investigation, the Historic period did not clearly begin in the Brownwood area until the A.D. 1850s (Wormser and Sullo-Prewitt 2001). At that time, full-scale colonization by farmers and ranchers from the United States of America began. The first settlers arrived in the mid-1850s and this settlement led to the establishment of Brown County in 1856. The primary use of the land was agriculture with ranches springing up in the later half of the 1800s. The railroad arrived in Brown County in the 1880s bringing more people that derived an income from ranching. They occupied the land as owners or tenants until 1940 when Camp Bowie was established (Leffler 2002). Aside from old ranches and farmsteads, there are also numerous remains of World War II era training facilities on Camp Bowie, consisting of concrete structures and earthworks related to weapons practice (Wormser and Sullo-Prewitt 2001).

\section{Previous Investigations}

A review of the archaeological literature for the Camp Bowie area produced limited results. Only a handful of excavation projects have been conducted, and with the exception of the two recent surveys of Camp Bowie (Mauldin and Broehm 2001; Wormser and Sullo-Prewitt 2001), few small surveys have been carried out. Archaeological research in the Brown County area dates to the early portion of the twentieth century with the excavations of J. E. Pearce at the burned rock midden site of Pitman (41BR3) conducted in 1919 (Campbell 1952; Kirby and Moir 1976). Pearce trenched two middens, both of which appeared to have been ring or crescent-shaped. While both contained large quantities of charcoal and fire-cracked limestone and a few fragments of bone and shell, it appears that neither midden contained any tools (Campbell 1952).

From the early work of Pearce in 1919 until the 1970s, no substantial archaeological investigations seem to have occurred in Brown County. Beginning in the early 1970s, a series of survey projects were conducted, including two by archaeologists from Texas A\&M University (Shafer et al. 1975a, 1975b). This spurt of activity involved a survey of Cordell and Camp Bowie City Park Sites in Brownwood by Kegley and Black (1978), a survey conducted by Southern Methodist University along Pecan Bayou north of Brownwood (Kirby and Moir 1976), and a survey by Prewitt and Associates for the City of Brownwood sanitary landfill site (Prikryl 1983). All of these surveys consistently recorded lithic scatters and burned rock features, including the presence of large ring and dome-shaped middens.

In 1979, the Texas Archeological Society Field School was located near Cross Cut in the far northwest corner of Brown County. Gearhart and Voellinger (1986) report that work was conducted on both ring and mound burned rock middens. In addition, Howard (1991) references excavations of three burned rock midden sites in Brown County (41BR72, 41BR105, and 41BR110). However, additional information on these projects could not be located.

In 1986, Espey, Huston \& Associates conducted testing at 41BR313 and 41BR314 (Gearhart and Voellinger 1986), two sites originally documented by Prikryl (1983) as a result of the sanitary landfill survey mentioned previously. A total of four 1-x-1-m units was excavated at these two sites. Testing did not reveal stratified deposits, and no additional work was conducted.

Prior to the 1993-1997 inventory survey of Camp Bowie (Wormser and Sullo-Prewitt 2001), little systematic work had been conducted on the installation. A portion of the Brownwood Laterals Watershed survey, conducted by Texas A\&M University in 1975 (Shafer et al. 1975b), was acquired by the Texas Army National Guard (TXARNG). Three sites (41BR65, 41BR66, and 41BR68) were incorporated into Camp Bowie as a result of that acquisition. In addition, 
Wormser and Sullo-Prewitt (2001:13) reference small-scale survey work on the camp conducted by Briggs (1992) as well as two TXARNG staff reports (Wormser et al. 1994, 1997).

TXARNG archaeologists conducted an inventory survey of 98.5\% of the total Camp Bowie area between 1993 and 1997 (Wormser and Sullo-Prewitt 2001). A total of 186 prehistoric and historic sites was recorded. A variety of prehistoric site types were identified, including open campsites, lithic workshops, lithic procurement sites, and burned rock midden sites. On the basis of that survey, Wormser and Sullo-Prewitt recommended 18 prehistoric sites as requiring testing to determine NRHP and SAL eligibility.

More recently, Mauldin et al. (2003) tested those 18 prehistoric sites recommended after the inventory survey (Wormser and Sullo-Prewitt 2001). On the basis of that testing effort, Mauldin et al. (2003) recommended that 12 sites (41BR65, 41BR87, 41BR228, 41BR246, 41BR250, 41BR253, 41BR420, 41BR433, 41BR473, 41BR478, 41BR492, and 41BR493) should be considered eligible for inclusion to the National Register of Historic Places and warranted designations as State Archeological Landmarks. The six remaining sites either lack clear evidence of significant data (41BR261 and 41BR276) or have data of questionable integrity (41BR415, 41BR441, 41BR474, and 41BR480). These sites were not recommended for NRHP inclusion, nor were they thought to warrant designation as State Archeological Landmarks.

During the TXARNG survey (Wormser and Sullo-Prewitt 2001), an area of 90 acres was under cultivation and not investigated at that time. The Center for Archaeological Research conducted the archaeological survey of the 90-acre area in 2001 (Mauldin and Broehm 2001) and discovered three prehistoric sites (41BR499, 41BR500, and 41BR501). Possible Late Archaic affiliation of 41BR500 was suggested from a single point and this site was recommended for additional testing. CAR continued its work in 2001 with the survey of three additional parcels totaling about 200 acres and revisited four previously recorded sites to undertake shovel testing (Greaves 2002). This work resulted in the discovery of one new burned rock midden site, 41BR522. Greaves recommended that site 41BR522, along with two of the revisited sites (41BR392 and 41BR471), should be tested for SAL and NRHP eligibility (Greaves 2002). It is from the two projects in 2001 that the current testing of 41BR392, 41BR471, 41BR500 and 41BR522 has resulted. 



\title{
Chapter 4:
}

\section{Research Issues}

\author{
Raymond P. Mauldin and Jason D. Weston
}

The previous two chapters provided a short overview of aspects of the natural and cultural background in the Camp Bowie area. This chapter outlines research issues that guided the archaeological research and provide a context for assessing the significance of the data available from the four sites tested on the current project. We begin this chapter with an introduction to eligibility considerations. This section is followed by a review of burned rock midden research, as two of the sites (41BR392 and 41BR522) contain these features and it was on the basis of these features that the two sites were recommended for testing. That section is followed by a discussion of research issues, focusing on chronology and subsistence, along with data needs for our work at the remaining two sites, 41BR471 and 41BR500. The final section provides a summary of the chapter.

\section{Eligibility, Integrity, and Research Issues}

The primary task identified in the scope of work for this project required an assessment of whether the archaeological sites tested on Camp Bowie may be eligible for inclusion on the National Register of Historic Places (NRHP) and eligible for designation as State Archeological Landmarks (SALs). As outlined in federal regulation 36 CFR 60.4, assuming that an archaeological site possesses integrity, it must also meet one of four criteria in order to be eligible for the National Register. Most, though certainly not all, archaeological sites are nominated for eligibility using criterion D. That criterion states that the properties "have yielded, or may be likely to yield, information important in prehistory or history." Designation as an SAL in Texas depends on an archaeological site meeting at least one of the five SAL criteria (Rules of Practice and Procedure for the Antiquities Code of Texas, Section 26.8). A site may qualify for SAL status if it: 1) has the potential to contribute to a better understanding of Texas history or prehistory by providing new information; 2) contains deposits that are preserved and intact; 3 ) it possesses unique or rare attributes concerning Texas prehistory or history; 4) offers unique opportunities to evaluate theories or methods of preservation; or 5) if there is a high likelihood the site may be subject to relic collecting leading to the destruction of any research potential.
In practice, both SAL and NRHP designation depends on somewhat similar criteria. The principal criteria used for evaluation generally involves the likelihood that data contained at a site can contribute new, unique, or superior information relevant to understanding local, regional, or state prehistory. Traditionally, this likelihood often depends on both the integrity of the data contained within those deposits and the nature of that data. If cultural or taphonomic processes significantly mix deposits within an archaeological site, the research potential of that site is often dismissed. In fact, Collins (1995:374-381, 388-389) has recently equated data quality with "greater integrity," and argued that such high integrity sites should be the focus of research in Texas. Sites excluded from additional considerations under this perspective often include surface sites, as they are subjected to a variety of processes that are not active on buried, sealed deposits. It is this latter class, the sealed, single-occupation site, frequently assumed to represent one or a small number of activities (e.g., lithic procurement, camping, quarrying) over a limited time frame, that is given high integrity ratings and frequently assumed to have high research value.

From our perspective, surface sites or sites that have mixed deposits that are traditionally seen as having low integrity and, by extension, low research value, are not intrinsically uninteresting. For some questions, sites with "high integrity" and good preservation may be critical. Other research questions may be effectively examined at sites that traditionally are viewed as having low integrity. For example, a research goal that requires reconstruction of some class of behavior during a particular time period would find sites that were repeatedly occupied over thousands of years to have low research value for that particular research question, if these occupations cannot be clearly separated. Conversely, single-component sites, traditionally viewed as having high integrity and high research potential, are of little use if research questions center on understanding processes of reoccupation or processes of long-term change in the use characteristics of a given location.

In our view, there is more involved in assessing the research potential of an assemblage than simply focusing on integrity considerations. While it is the case that the data contained within mixed or low integrity sites may be applicable to a more narrow range of research issues when contrasted to 
high integrity deposits, archaeological sites, and the data they contain, should be evaluated by reference not to integrity as such, but rather to the extant knowledge base and specific research questions. Nevertheless, it is clearly necessary to assess the integrity of deposits, as well as the integrity of features, within a site, in order to be able to assess what research issues may be appropriately addressed with these data. We identify four different data patterns that will be used to assess the integrity of the archaeological deposits on the four sites tested during this project. These related data patterns are: 1) the presence of buried deposits and/or the presence of surface deposits with distinctive concentrations of material; 2) subsurface patterns of artifacts indicating peaks of deposition that may indicate distinctive periods of occupation; 3 ) the presence of recognizable features, especially those that have minimal evidence of disturbance; and 4) data on the presence, nature, and amount of turbation within the site sediments, including both natural (e.g., animal burrowing, erosion, deposition) and cultural (e.g., modern activity, historic intrusions) processes.

The combination of these four different data sets will allow us to provide an initial assessment of the integrity of deposits and features at a site. The value of archaeological deposits within a site is dependent, however, not on the integrity as such, but on the research questions being asked of those data. The research questions asked, in turn, are related both to our current state of knowledge, our available methodologies, and our inventiveness. For the current testing work at Camp Bowie, then, it is necessary to outline some general research directions in order to guide both the collection of data as well as provide a context for evaluation of those data. In the following section, we begin this task by outlining what we think we know about burned rock middens, with specific focus on this feature type at Camp Bowie. We focus on three general research issues, including understanding what these features represent, what was processed in these features, and when these features were used. We then identify specific data needs from the middens on sites 41BR392 and 41BR522 that may provide information on these research issues.

\section{Research Issues at 41BR392 and 41BR522: Understanding the Development, Chronology, and Subsistence Role of Burned Rock Middens}

As noted in Chapter 1, one of the central components of this current investigation is centered on burned rock middens. Two of these features, one at 41BR392 and one at 41BR522, were tested on this project. Consequently, this section provides a short overview of the history of research on these feature types. A number of more detailed accounts of this research topic are available (see Black and Creel 1997; Collins 1991; Creel 1986; Howard 1991; Prewitt 1985, 1991; Treece 1993; Weir 1976), including summaries of recent work on similar features at Camp Bowie (see Mauldin et al. 2003).

In composition, a burned rock midden is an accumulation of soil and rocks, with the rocks being cracked or broken by heat stress. Some of these burned rock middens also contain varying amounts of other artifacts such as debitage, projectile points, and plant and animal remains (see Howard 1991). Since their original investigation in Texas more than 80 years ago (Pearce 1919), three general topics have come to dominate burned rock midden research. These topics are concerned with: 1) how these features formed; 2) what these features were used for; and 3) when these features were used.

\section{The Formation of Burned Rock Middens}

It was while investigating an artifact laden burned rock "mound" in 1919 that J. E. Pearce called such features kitchen middens (Collins 1991), suggesting that burned rock middens were simply general refuse piles that include a large quantity of burned rock from hearths (Pearce 1919). Later investigations have concluded that burned rock middens are the remnants of a specific-function feature used in food preparation. However, there is a great deal of variety seen in burned rock middens. In an attempt to organize this variety into a coherent picture, burned rock features have often been put into one of several classification schemes. Most commonly, this classification is done in reference to midden shapes (e.g., Creel 1986: Prewitt 1991; Weir 1976). Others approach burned rock middens as a general feature category (see Collins 1991; Mahoney 2003). 
Most typologies seem to share elements of one of three common models of burned rock midden formation. One model, put forth in the 1940s (Kelley and Campbell 1942), concerns the creation of a midden through the repeated use of a general area for hearths lined with stone. This is called the Intersecting Hearth Model, and is similar to Prewitt's and Collins' intersecting hearths and Mahoney's burned rock sheet middens (Mahoney 2003). A second model suggests that burned rock middens are the result of dumping broken hearth stones in a general refuse pile away from their original location of use, often along with a wide variety of other discarded cultural materials. This is in essence a true midden, known as the Communal Dump Model. The third and final model is the earth oven or Central Feature Model (see Black and Creel 1997; Mauldin et al. 2003), aspects of which were first expounded by Pearce (1919). This model suggests that burned rock middens are focused around a central hearth/ thermal feature. These types of burned rock middens are identified as earth ovens (see overview in Mauldin et al. 2003). Such features are accumulations of heat-broken rock with smaller rock thrown away from the central hearth that is then re-lined with unburned, larger rock. Rock-lined earth ovens often take the form of a ring-shaped burned rock midden (see Black 1997; Mauldin et al. 2003; Nickels et al. 2001; Treece 1993). As such, these are earth ovens rather than general discard piles as is implied by the term "midden." Despite this observation, the term burned rock midden will continue to be used owing to convention.

In order to assess which of these various models best describes the two middens tested on sites 41BR392 and 41BR522, various data sets are required. These include information on the size and location of burned rock, with samples from the centers as well as the rings of the middens (see Mauldin et al. 2003), data on artifact and ecofact content of the middens relative to off-midden areas, and basic descriptive information on midden shape.

\section{The Use of Burned Rock Middens}

Regardless of which of the typological schemes is adopted, most researchers seem to have arrived at the conclusion that burned rock middens are the result of using fire in conjunction with rock to prepare some type of food for consumption (Black et al. 1997; Creel 1986, 1991; Howard 1991). Despite agreement as to the general purpose, debate rages as to exactly what was cooked, baked, or otherwise prepared for consumption in these features.
Many early investigators of these feature types in Texas (e.g., Pearce 1919; Kelley and Campbell 1942) assumed that middens represented the remains of generalized cooking activities rather than a focus on any particular food resource. Wilson (1930:59-61) appears to have been one of the first researchers to suggest that middens may represent a more specialized subsistence focus. Specifically, he suggested, based in part on ethnographic accounts of the use of similar features in the American Southwest, that middens were the result of specialized processing of sotol. Subsequently, other researchers began to focus on individual plant foods as possible candidates for processing in burned rock middens.

Foremost among these suggested plants were acorns. The notion that acorns were a primary food processed in burned rock middens in Texas was probably first suggested by Hester (1973) who noted that many burned rock midden sites were associated with oak groves (see also Black and McGraw 1985; Gunn and Mahula 1977:279; Turner 1989; Weir 1976:125). Creel (1978, 1986, 1991, 1997) subsequently has demonstrated a significant relationship between oak distribution and burned rock middens. However, compilations of ethnobotanical data from burned rock middens (see Dering 1997; Howard 1991) demonstrate that a variety of carbonized seeds and fruit fragments have been recovered from midden contexts, including sotol, yucca, prickly pear pads and seeds, acorns, and geophytes. In addition, a variety of animal remains have been identified in middens, including deer, bison, cottontail rabbit, turtle, and mussel shell (see Decker 1997; Neck 1997). Citing this diversity of resources, Black and Creel (1997) suggest that a variety of different food stuffs may have been processed, and that the search for a single group of plants or animals that were consistently processed with burned rock middens may not be productive.

Recent work on Camp Bowie burned rock middens, however, has suggested that a single type of resource may be the focus of these particular middens (Mauldin et al. 2003). Based on recovery in both flotation samples and on the basis of macrobotanical identifications, Dering (2003) identified over 400 bulbs and bulb fragments in 10 different middens on nine different sites at Camp Bowie. The vast majority of these bulbs and bulb fragments were camas, though other geophytes, including wild onion, were also recovered. Mauldin et al. (2003), following earlier researchers (e.g., Dering 1999; Thoms 1989; Wandsnider 1997), argued that these types of high starch plants require 
a combination of long-term heating and moisture in order to transform the raw, indigestible starches into digestible simple sugars. Burned rock oven features are ideal for this type of processing.

In order to investigate what was processed in the two burned rock features tested on the current project, we needed information on the quantity and nature of ethnobotanical material present in these features. In addition, data on the quantity and types of faunal recovery from middens help address this research issue if it can be shown that these materials were not brought into the midden by secondary processes.

\section{The Chronology of Burned Rock Middens}

The final major research question concerning burned rock middens has focused on when these feature types were formed. Several early researchers (e.g., Huskey 1935; Pearce 1932:49) suggested the possibility that middens were formed both in the Archaic as well as in the Late Prehistoric periods. For example, Huskey (1935:109) observed that certain strata within middens were characterized by "small arrow and bird points," while other middens and strata within middens were dominated by projectile point forms that were Archaic in age. More recently, Weir (1976:34-40), relying on associated diagnostic artifacts, suggested that middens probably began to be used around $5000 \mathrm{BP}$, with some use continuing into the Late Prehistoric. He suggests that the most intensive period of use was probably between about 2800 and 1800 BP. More recently, Prewitt, using diagnostic artifacts supported by radiocarbon dates, argues that most middens date to the period between $5000 \mathrm{BP}$ and $1750 \mathrm{BP}$, with peak use occurring between 4600 and $4000 \mathrm{BP}$ (Prewitt 1981:73-76, 1985, 1991). During the 1970s, 1980s and early 1990s, then, most researchers argued that these features were used primarily during the Archaic (see Collins 1991; Houk and Lohse 1993:193-248; Johnson 1995). While there were certainly reports of Late Prehistoric middens (e.g., Goode 1991; Lukowski 1987; Treece 1993), these were often considered anomalous rather than characteristic of the true period of midden use.

Within the last 10 years, however, this perspective has begun to change. For example, Black and Creel (1997; see also Treece 1993) have summarized 141 radiocarbon dates from 35 middens on 29 sites located in central Texas. These dates suggest that while middens have radiocarbon dates that cover over 8,000 years, the majority of dates fall within the last 2,000 years, and most appear to date to the Late Prehistoric period. While Black and Creel (1997:273-280) acknowledge the possibility that the overall dated distribution may be impacted by differential preservation of organic material, their data clearly suggest a Late Prehistoric focus for this feature type.

Mauldin and Nickels (2003) have recently considered the temporal placement of burned rock middens by acquiring radiocarbon dates for 14 different sites within Camp Bowie. Thirty-one radiocarbon dates, from 17 different middens, clearly suggest a Late Prehistoric focus for Camp Bowie burned rock middens. In short, 28 of the 31 dates (about $90 \%$ ) fall between A.D. 750 and A.D. 1400. One date was centered at roughly A.D. 600 , and there were two earlier dates at roughly 600 B.C. and at 1200 B.C. To the degree that these 31 dates reflect the period of midden use, the Camp Bowie middens were primarily used during the Late Prehistoric period, with minimal Late Archaic use.

In order to consider the utility of the two middens at sites 41BR392 and 41BR522 to address chronological concerns, we needed data on the distribution and density of diagnostic artifacts both within and outside of the middens. In addition, information on the potential for charcoal recovery for radiocarbon dating within the features was a critical element.

\section{Research Issues at 41BR471 and 41BR500: Investigating Chronology, Subsistence, and Settlement}

The previous discussion has outlined a series of general research issues for burned rock middens, and presented data needs that may be relevant to assessing the significance of these two features on sites 41BR392 and 41BR522. For the remaining two sites, 41BR471 and 41BR500, two basic research issues concerning chronology and subsistence, are outlined.

Previous work at 41BR471 (Greaves 2002:26-30) had suggested that the site probably lacked any significant subsurface material, though testing was minimal. No features were noted on the surface, though a moderate to high-density surface scatter of artifacts was identified and a single projectile point fragment was recovered from the surface. The point, a broken Late Prehistoric specimen, resembled a Toyah or Harrell form, though specific assignment was not 
possible. Greaves (2002:30) suggests that the site may represent a short-term use area, possibly dating to the Late Prehistoric period (circa 1250-450 BP).

Site 41BR500 was initially recorded by Mauldin and Broehm (2001:20-21). The site had high surface densities of artifacts, though much of 41BR500 had been disturbed by plowing activity associated with a modern field, as well as by a large berm and a road or channel. Shovel testing established that subsurface deposits were present at several locations, and a single shovel test in the undisturbed portion of the site recovered sandstone and debitage. That shovel test also produced high magnetic soil susceptibility values. This combination of attributes strongly suggested a possible buried feature or surface at this location. Two diagnostic points from this site, a Darl and a Pedernales, suggest a Late Archaic temporal focus, though these forms span much of this long temporal period (circa 3950 to $1250 \mathrm{BP}$ ).

\section{Chronological Patterns}

The chronological sequence established for Central Texas, reviewed in the previous chapter, is based on what are primarily stylistic changes in projectile points, though other tools are sometimes considered. The basis of the currently used Central Texas chronology dates to the publication of the Handbook of Texas Archaeology (Suhm et al. 1954), though early schemes were certainly proposed (see Kelley 1947). The type descriptions presented in the Handbook were primarily developed in a strict cultural history framework, with the stylistic changes in projectile points indicative of historical relationships. Subsequently, these same forms have been co-opted into a more strictly chronological framework, though cultural history overtones are certainly still present in most applications. The stylistic changes in points are associated, in some cases, with radiocarbon dates (e.g., Prewitt 1985; Weir 1976:29), though many types remain poorly dated or the temporal range is extensive (e.g., Turner and Hester 1999). In some cases, these types are poorly defined (e.g., Mahoney et al. 2002:71-132).

A variety of different higher-order groupings of these various point styles, some of which have slightly different temporal ranges for period assignments, have been presented (e.g., Collins 1995; Johnson and Goode 1994; Turner and Hester 1999). These temporal periods (e.g., Late Archaic) are generally long, with the shortest temporal range being roughly 800 years and most periods being over 2,000 years in duration. The periods appear to be designed to span time frames that reflect a somewhat uniform material culture, and the initiation of a given period is usually argued to reflect major change in human behavior, a shift most recently associated with climatic change (e.g., Johnson and Goode 1994:15-17; see also Weir 1976:2-7). In addition, a variety of phase assignments (e.g., Prewitt 1981; Weir 1976) have been suggested for each period, though they are not commonly used in discussions of most periods. The phase designations appear to represent an attempt to more clearly identify smaller-scale changes within these longer periods (e.g., Weir 1976:3-4, 23-29).

Establishing a reasonably limited chronology for associated archaeological remains is a necessary element of most current research investigations. Investigations of research issues commonly pursued today, such as changes in settlement patterns, changes in subsistence, and changes in technology, frequently necessitate a tightly established chronology. However, as hinted at above, the temporal range of some projectile points, as well as the length of periods and phases, are not well established in all cases. The previous site summaries suggest that both sites 41BR471 and 41BR500 can be assigned to a temporal period, with the former dating to the Late Prehistoric, and the latter dating to the Late Archaic. However, neither of these sites can be more tightly dated than these period level assignments. The Late Prehistoric point at 41BR471, which resembles forms found more often in western Texas and the panhandle region (i.e., Toyah or Harrell), could not be positively identified to a specific type. The Darl point from 41BR500 seems to date to around $1750 \mathrm{BP}$ (Turner and Hester 1999:101), while the Pedernales point may date to between $3950 \mathrm{BP}$ and $3150 \mathrm{BP}$ (Turner and Hester 1999:171). Occupation at the site, then, could conceivably span over 2,000 years. Note also that only three points are available from these two sites. While the single point from 41BR471 may provide an approximate date for this small assemblage, it is unlikely that the two points from 41BR500 accurately date this relatively large assemblage. Clearly, additional diagnostic artifacts that may refine the chronological placement of the assemblages at 41BR471 and 41BR500 were needed. In addition, charcoal for radiocarbon dating would provide independent dates for the assemblages at these sites.

\section{Subsistence Information}

As noted previously, building a chronological framework has been a focus of Central Texas archaeological work, and a number of different summaries are available. Research 
into subsistence patterns has been much more spotty and has generally focused on the individual site or feature level. While a number of resource-specific (e.g., Dillehay 1974) or feature-specific investigations (e.g., Creel 1997) exist that cover the Central Texas region, synthetic summaries of subsistence, analogous to the chronological syntheses discussed previously, are generally lacking. In part, this is related to preservation conditions, with much of what we know being derived from cave and shelter excavations with good preservation conditions. Carbonized plant remains are not common in open sites. In addition, it appears that flotation analysis has become a standard practice in the Central Texas region only within the last 25 years. While faunal research has a much longer history of research in the central portion of the state, detailed analysis is often limited by preservation conditions and taphonomic processes. What we do suspect about subsistence seems to be heavily influenced by ethnographic and ethnohistoric accounts, rather than directly derived from archaeological research.

The generic overview of subsistence at a period level (e.g., Late Archaic), presented in the previous chapter, suggests that our archaeologically derived understanding of specific patterns of subsistence for the region is limited. Consequently, any information with relevance to subsistence that can be derived from our testing at these sites can potentially make a significant contribution. With this perspective in mind, two data sets from sites 41BR471 and 41BR500 were specifically targeted to investigate subsistence. The first data set was the potential recovery of ethnobotanical remains from features. While no features were known for site 41BR471, a feature was suspected at site 41BR500. If a feature was discovered at this site, and if that feature had good ethnobotanical recovery, then the site can make a significant contribution to our understanding of subsistence, especially if chronological placement of the feature was possible. Faunal recovery from testing at these two sites, again coupled with chronological refinement, could also add important information to our understanding of subsistence.

\section{Summary}

The primary task identified in the scope of work for this project required an eligibility assessment of four archaeological sites, 41BR392, 41BR471, 41BR500, and 41BR522, for possible NRHP inclusion and SAL designations. Therefore, this chapter has reviewed issues regarding eligibility. That review included a discussion of the criteria that was used to assess sites, as well as a review of issues surrounding integrity and research questions. Two of the sites contained burned rock middens, and it was on the basis of that feature type that these locations were recommended for testing. As such, we have provided a short overview of burned rock midden research, and identified several data types that could make a significant contribution to our understanding of burned rock middens. In addition, we have provided short reviews of chronological and subsistence concerns that guided data collection and assessment at the two remaining sites, 41BR471 and 41BR500. 


\title{
Chapter 5: $\quad$ Methodology and Theory
}

\author{
Jason D. Weston
}

Consistent with the Specification for Services, four prehistoric archaeological sites were tested by a seven to ten-member crew from the Center for Archaeological Research (CAR). The work was conducted during August of 2002. This chapter outlines the field and laboratory methods used on the project.

\section{General Field Methods}

The primary objective of the testing efforts at the four sites was to determine site NRHP eligibility and SAL designations. Each archaeological site is categorized as either 1) eligible or 2) not eligible for inclusion to the NRHP; and/or 1) warranted or 2) not warranted for SAL designation. Specific research issues and data needs for each site were discussed in the previous chapter. To address these research issues, testing efforts focused on acquiring information on the nature of the features found on the sites, the determination of their physical and/or cultural integrity, and the identification, recovery, and context of a variety of archaeological data types (e.g., faunal remains, ethnobotanical remains, datable charcoal samples, diagnostic artifacts) that may yield information regarding the broader research issues discussed in the previous chapter.

During the testing-related excavations on each site, the project geomorphologist examined the geomorphological setting to identify the processes operating on and impacting archaeological materials. These investigations had two main goals: 1) the definition of the geomorphological integrity of the site; and 2) the identification of depositional settings that may yield buried and undisturbed materials. Site testing efforts aimed at answering the issue of physical integrity focused on any features present, such as burned rock middens, buried hearths, lithic concentrations, and such. In general, these efforts incorporated the excavation of multiple, adjoined 1-x-1-m test units within the midden, the excavation of single 1-x-1-m units centered on isolated hearth features or artifact concentrations, and the excavation of a limited number of non-feature centered $1-x-1-m$ units to determine the nature and integrity of the site's cultural stratigraphy.
Shovel tests were $30-35 \mathrm{~cm}$ in diameter. All shovel tests and 1-x-1-m units were excavated in 10-cm arbitrary levels (unless otherwise noted in the site discussions) and all matrix was screened through $1 / 4$-inch mesh. Matrix samples were collected from specific contexts and were screened through 1/16-inch mesh in the laboratory at CAR.

Testing efforts dealing with the second aspect of site eligibility combines data derived from midden-centered work with off-midden explorations to define the potential relationship between features, activity areas, and archaeological remains. These efforts include artifact samples from off-midden shovel tests and the artifacts obtained from nonfeature centered $1-x-1-m$ excavation units. In addition, radiocarbon samples and matrix samples intended for ethnobotanical and geomorphological analysis were obtained from three of the four sites. Samples were collected from each on-midden and off-midden excavation unit as well as from units with isolated thermal features. These comparisons allow discussion of the temporal relationship between activities performed in association with the burned rock middens and those identified away from the middens. The radiocarbon samples from middens were taken from the ring units where the deposits have a lower likelihood of being disturbed than in the center units (see section on burned rock middens later in this chapter). Magnetic sediment susceptibility samples were collected from two sites (41BR392 and 41BR500). These samples, collected from selected profiles, consisted of sediment extracted at $5-\mathrm{cm}$ intervals along a profile. As discussed in Appendix C, the samples may provide information on buried surfaces.

The locations of sub-datums, test units, shovel tests and surface collection areas at each site were mapped using a Trimble Geo Explorer II GPS unit and backed up by site mapping using an electronic survey instrument, a Sokkia Set 6E Total Station with the SDR33 Data Collector. Photos were taken and photo logs kept. Feature logs were employed when needed and field notes were taken. Standardized forms were used for recording shovel test results and test units were recorded on standardized unit/ level forms. Plan view maps, profiles and other drawings were created when necessary. 


\section{Site-Specific Field Methods}

The four sites of this testing project can be divided into two basic categories: open campsites and burned rock midden sites. Sites 41BR471 and 41BR500 are open campsites and 41BR392 and 41BR522 are burned rock midden sites.

Open campsite (41BR471 and 41BR500) is a highly general term used to define any site that is not in a rockshelter or cannot be given a specific function label such as quarry site, kill site, or in this case, burned rock midden site. While 41BR471 and 41BR500 are both open campsites, they required different approaches which are detailed below.

\section{$41 \mathrm{BR} 392$ and 41BR522}

At the burned rock midden sites of 41BR392 and 41BR522, shovel tests were excavated on a 5-x-5-m grid around two or three sides of the midden, depending on topography, with several shovel tests dug off-grid and farther away from the midden to test for more distant deposits. The shovel tests were excavated to a maximum depth of $60 \mathrm{~cm}$ below surface (bs) or until sterile deposits were encountered. All culturally modified artifacts were bagged and labeled with the appropriate provenience information and returned to the CAR laboratory where they were processed, cataloged, and analyzed. From the surface, only temporally and technologically diagnostic artifacts spotted in the course of fieldwork were collected. The densities of debitage, tools, and burned rock were summarized for each shovel test allowing the recognition of subsurface artifact concentrations across the site. Based on such recognitions, 1-x-1-m hand-excavated units were positioned in off-midden areas to explore artifact concentrations.

Test units on the middens consisted of a 1-x-2-m unit in the center of each midden, cross-cutting the central depression, and a 1-x-1-m unit on the talus of the ring of each midden. The 1-x-2-m unit was intended to expose the structure of the central depression and identify any reuse episodes (i.e., different basin floors). The unit positioned on the talus of the midden was intended to document the structure of the midden near its perimeter. The documentation of burned rock size away from the central depression was one of the primary goals of this unit placement. The excavation also allowed exploration for any hearth features that may have been constructed in the talus following the abandonment of the oven itself. All chipped lithic artifacts, mussel shell, and all carbonized plant remains were collected for analysis. A one-liter matrix sample was taken from each 10 -cm level in all of the excavation units on sites 41BR392 and 41BR522 for flotation and the recovery of botanical remains.

All burned rock was not retained for laboratory analysis, since a basic analysis (i.e., maximum size measurement using nested screens) was performed in the field to document changes in maximum size with increasing depth from surface and distance from the central feature. A small sample of the burned rock was collected for future analyses.

Magnetic sediment susceptibility samples were collected from specific profiles at site 41BR392.

\section{$41 \mathrm{BR} 471$}

Earlier surveys showed the archaeological deposits at 41BR471 to be mainly a surface exposure with some minor amount of buried material. For the best recovery of artifacts, surface collections were conducted in the areas of the densest concentrations. Collection was done using radials, referred to as dog leashes (DL). These were based on a central pivot. All artifacts within one meter of this pivot were collected resulting in a circular collection area two meters in diameter. Two test units were excavated in the manner detailed under General Field Methods. These units aided in determining whether the surface finds represent slow erosion of thin soils resulting in the exposure of shallowly buried materials or materials thinly covered by colluvial sheetwash.

\section{BR500}

Work at 41BR500 examined the intact western edge of the heavily disturbed site. Shovel tests were placed in a single transect, testing for buried deposits. On the basis of shovel test results, a 1-x-1-m test unit was placed in the area of the highest artifact concentration. The buried burned rock located on the site by earlier shovel testing was explored using three adjoining 1-x-1-m units. Soil matrix samples from each level in all units and from all contacted features were floated and macrobotanical remains were retained for analysis. Magnetic sediment susceptibility samples were collected from specific profiles at site 41BR500.

\section{Laboratory Methods}

All cultural material collected during testing was prepared in accordance with federal regulation 36 CFR part 79, and in accordance with current guidelines of the Texas Archeological Research Laboratory (TARL). Artifacts 
processed in the CAR laboratory were washed, aid-dried, sorted into the appropriate artifact categories, analyzed, and stored in archival-quality bags. Acid-free labels were placed in all artifact bags. Each label contains a provenience and corresponding lot number. Tools have been labeled with permanent ink and covered by a clear coat of acrylic. In addition, a small sample of unmodified debitage from each lot was labeled with the appropriate provenience data. All artifacts are stored in acid-free boxes. Boxes are labeled with standard labels. Field notes, forms, photographs and drawings have been placed in labeled notebooks. Photographs, slides and negatives are in archival-quality sleeves. All documents and forms are printed on acid-free paper and have been stored in acid-free boxes. Upon completion of the project, all cultural materials and records were sent to TARL for permanent storage.

\section{Analysis Notes}

\section{Lithic Analysis}

One measure of reduction activities used in this report is the thickness to length ratio of complete flakes. The thickness to length ratio $(\mathrm{TH} / \mathrm{L})$ was calculated to gauge the stage of lithic production dominant at each site. Each stage of reduction has a typical thickness to length ratio range. The ratio range system used here is modeled on the system used for the lithic analysis done by CAR personnel for debitage from Camp Swift (Robinson et al. 2001) and from Camp Maxey (Mahoney et al. 2002). The system, with minor modifications, is as follows: a thickness to length ratio less than or equal to .15 results from late stage lithic reduction; a ratio of .16 to .25 indicates tool manufacture; and a ratio of .26 or greater indicates early stage reduction. For the open campsites (41BR471 and 41BR500) the calculations have been based on the total number of complete flakes from all proveniences of the site. For the burned rock midden sites (41BR392 and 41BR522) the ratios based on complete flakes were calculated separately for on-midden and offmidden units to check for the presence of any differences linked to the midden feature.

\section{Radiocarbon Dating}

Carbon 14 samples recovered during excavation consist of 44 charcoal samples from three of the four sites (41BR392, 41BR500, and 41BR522). Of these, six were sent to Beta Analytic, Inc. in Miami, Florida and analyzed using the standard AMS (Accelerator Mass Spectrometer) technique.
While the resulting calibrated dates are in the main body of this report, the complete report of results on the radiocarbon dating are provided in Appendix A.

\section{Botanical Analysis}

The analysis of light fraction plant remains from soil flotation and carbonized plant remains from excavation units were analyzed by Dr. Philip Dering at Texas A\&M University. The conclusions of the botanical analysis are used in the main report. Greater detail on the findings of the analysis, specific information on methods, and ethnographic accounts are presented in Appendix B.

\section{Magnetic Sediment Susceptibility}

All analysis of susceptibility samples was conducted at the CAR laboratory using a MS2B dual frequency sensor in conjunction with a MS2 Magnetic Susceptibility Meter. The analysis requires only small quantities of soil (about 15 grams) and yields quantified results that are highly replicable (see Dearing 1999). Analytical details can be found in Appendix C. 



\title{
Chapter 6: $\quad$ Testing Results at Site 41 BR392
}

\author{
Jason D. Weston, Raymond P. Mauldin, and Bryant Saner, Jr.
}

In this chapter, the results of CAR's testing at site 41BR392 are discussed. This site contained a single burned rock midden. A discussion of the site is presented, including details on all artifacts, radiocarbon dates, and macrobotanical samples. In addition, the structure of the burned rock midden is investigated.

\section{Site $41 B R 392$}

The testing at 41BR392 centered on and around the prehistoric burned rock midden in the extreme northwest corner of the site. Although there is a historic component on the site, including several architectural features (see Wormser and Sullo-Prewitt 2001:87), the evaluation of this site was focused on the prehistoric occupation. Greaves (2002:30-32) recorded the prehistoric sandstone midden, and placed two shovel tests at the site. Shovel Test 1 (ST 1) was placed near the center of the feature in order to verify that it did represent a burned rock midden, while ST 2 was placed just off the feature to provide information on the depth and character of the deposits. ST 1 did encounter sediments characteristic of a burned rock midden, and ST 2 produced a single flake at $40-50 \mathrm{cmbs}$. In addition, Greaves (2002:32) reports a single Bulverde projectile point, manufactured during the late Middle Archaic or early Late Archaic, was collected from the surface. Figure 6-1, adapted from Greaves (2002:31), presents the locations of the two shovel tests, as well as the locations of the midden, the surface-collected point, and several historic features. The burned rock midden at this site is oval in outline, measuring approximately $12 \mathrm{~m}$ by $15 \mathrm{~m}$. The midden is approximately $60 \mathrm{~cm}$ in height above the current ground surface. A central depression is present, being roughly 5 to $8 \mathrm{~cm}$ lower than the surrounding midden ring. The midden is truncated on the extreme northwest edge by a historic rock wall. In addition, a series of smaller berms, probably associated with the construction of a cattle tank just to the west of the site, are present to the west of the midden.

Testing at this site involved the excavation of 25 shovel tests and five 1-x-1-m test units. As can be seen in Figure $6-2$, most of the shovel tests $(n=20)$ were either in the feature $(n=2$, STs 15 and 16), or were placed in a 5-m grid pattern concentrated to the east and south of the midden $(n=18)$. These shovel tests were within $15 \mathrm{~m}$ of the midden edge.
Five additional shovel tests (STs 21-25) were placed farther from the midden, averaging roughly $26 \mathrm{~m}$ from the midden edge. The shovel tests were excavated to an average depth of $52 \mathrm{cmbs}$, with a minimum depth of $40 \mathrm{~cm}$ and a maximum depth of $60 \mathrm{~cm}$. During this phase of work at 41BR392, 130 separate levels were excavated.

In addition to the shovel testing, two test units (TUs 1 and 2) were placed in the center of the midden, and a third unit (TU 3) was placed on the midden ring. Two test units (TUs 4 and 5) were placed off of the midden. TU 4 was placed near ST 10 in order to explore a high-density deposit of chipped stone discovered in that shovel test. TU 5 was placed near ST 7 in order to provide data on subsurface patterns away from the midden area.

\section{Shovel Test Results}

Twenty-two of the 25 shovel tests were positive with the recovery of chipped stone, burned rock, or mussel shell. Both chipped stone and shell were collected, while burned rock was simply noted and left in the field. As can be seen in Figure 6-2, both of the midden shovel tests were positive, as were all shovel tests located close to the midden. The three negative shovel tests were all located in the outer ring of tests. The high frequency of positive shovel tests centered on the midden suggests that this feature was a focus of the prehistoric occupation in this area of the site.

Chipped stone was present in 17 of the 25 shovel tests, mussel shell was present in 18 of the tests, and burned rock was present in 19 of the tests. Not surprisingly, given the nature of the midden, burned rock was the most commonly recorded item, being represented in 61 of the 130 shovel test levels (47\%). Chipped stone, conversely, was present in only 27 of the 130 levels $(21 \%)$.

Focusing on the non-midden shovel tests $(n=23)$, Figure 6-3 presents the percentage of the 82 chipped stone items (black bars) and the 63.1 grams of mussel shell (gray bars) by level. None of the chipped stone items were recovered below Level 4 (30-40 cmbs), and roughly $90 \%$ of the items were found in Levels 2, 3, and 4. In part, this vertical distribution of chipped stone is deceiving in that three shovel tests (STs 9, 10, and 11), all located immediately to the east 


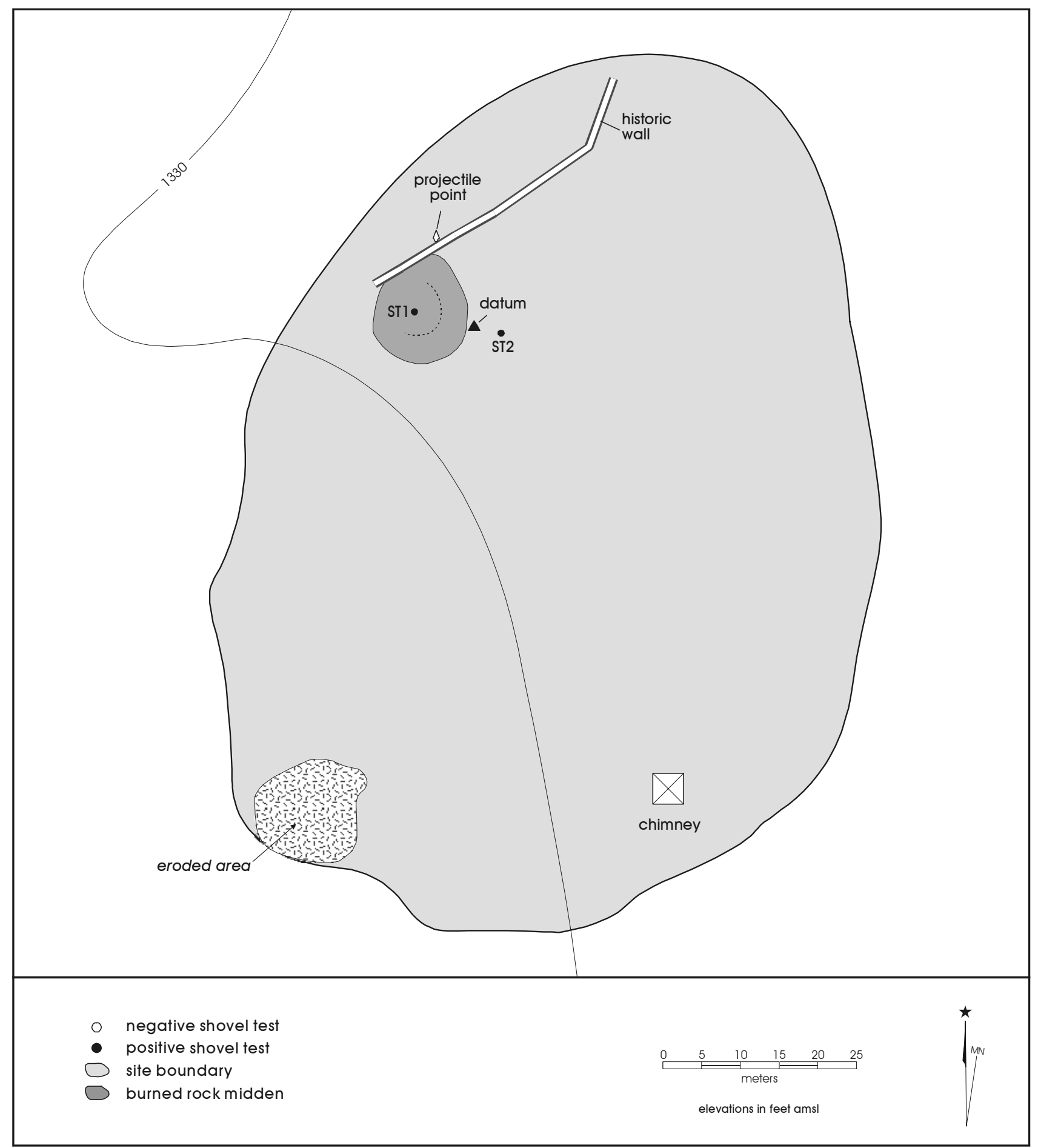

Figure 6-1. Site boundary and previous work at $41 B R 392$. 


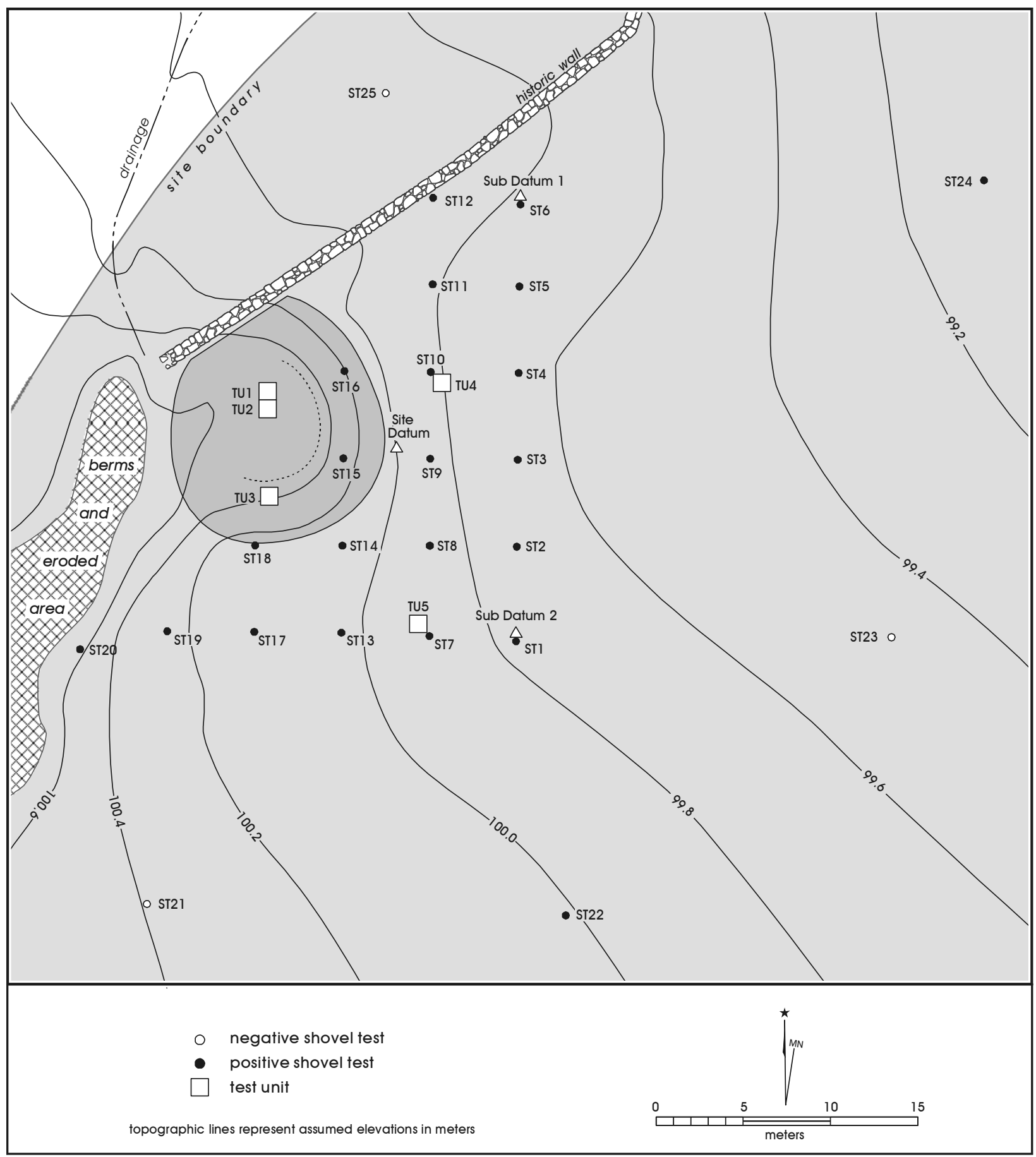

Figure 6-2. Shovel test and test unit locations for current work at $41 B R 392$. 
of the midden (see Figure 6-2), account for $67 \%$ of the chipped stone debris $(\mathrm{n}=55)$, and one of these shovel tests (ST 11) contains $92 \%$ of all material recorded from Level 4. Removing the 24 items from Level 4 in ST 11, the remaining material is concentrated primarily in Levels 2 and $3(10-30 \mathrm{cmbs})$.

The vertical distribution of mussel shell weight (gray bars, Figure 6-3) does not mirror the chipped stone distribution. Most of the shell is concentrated in Level $2(10-20 \mathrm{cmbs})$, and the shell has a wider vertical range, being present down to $50 \mathrm{cmbs}$. Nevertheless, shell seems to be spatially concentrated near the midden, with the three highest shell weights occurring in ST 14 (14.3 grams), ST 10 (11.6 grams), and ST 11 (11.5 grams). Note that both the concentration of shell near the midden, and the observation that two of the shovel tests with high shell weights (STs 10 and 11) also had high chipped stone weights, suggests that some component of the shell may be cultural in origin, and the shell may be related to midden use.

Several historic artifacts were found during the shovel testing. Since we were focused on the prehistoric material for this evaluation, these were not included as indicative of a "positive" shovel test in Figure 6-2. The nature and distribution of these artifacts, however, are briefly summarized here as they have implications for the subsurface integrity of the prehistoric material. While the construction of the rock wall (see Figures 6-1 and 6-2) has potentially impacted the northern edge of the midden, the number and distribution of the historic artifacts is surprisingly limited. Several historic items were found in the outlying shovel tests. Two historic items were found on the surface near ST 24. These included one dark purple glass fragment and an aqua colored glass lip and neck fragment. The dark purple glass fragment probably dates to the late 1880 s or early 1900 s (Polak 2000). The aqua fragment is a tooled, rounded, rolledover collar type. The color is caused by naturally occurring iron in the sand used to make the glass. This type of glass was made primarily during the last half of the 1800 s, but a few aqua glass bottles were manufactured after 1900 (Munsey 1970). A round, wire cut nail was recovered from ST 21 at $0-10$ cmbs. Wire cut nails first appeared about 1860 , and by the 1920 s they were the most common type of nail on the market (Wells 1998). Closer to the midden area, three shovel tests had historic materials. A 1927 D Lincoln "wheat back" penny was recovered from ST 8 at 0-10 cmbs. A piece of wire was recovered from ST 14 at 10-20 cmbs.

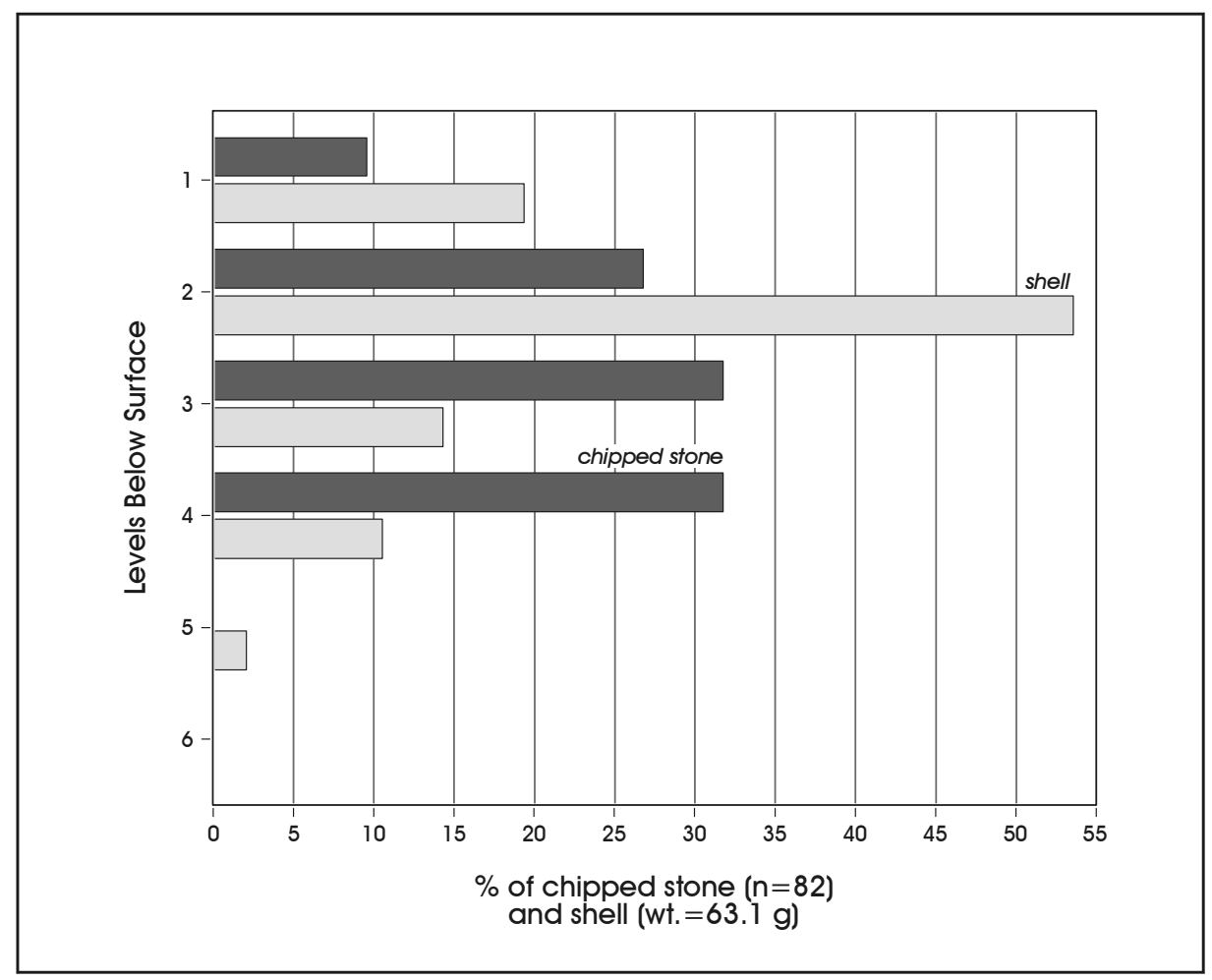

Figure 6-3. Percentages of chipped stone and mussel shell by level from shovel tests at $41 B R 392$. 
Finally, an unidentified brass fragment was recovered from ST 6 at $0-10$ cmbs. Only three historic artifacts were recovered from shovel tests close to the midden, and the historic material was restricted to the upper $20 \mathrm{~cm}$ of deposits, with two items between 0 and $10 \mathrm{cmbs}$.

\section{Test Unit Results}

As noted previously, five 1-x-1-m test units were placed on the site, with three of these placed in the midden and two units (TUs 4 and 5) placed off the midden. TUs 1, 2, and 3 were excavated in the midden, with TU 3 placed on the outer ring area and TUs 1 and 2 placed in the feature center (Figure 6-2). Roughly $1.84 \mathrm{~m}^{3}$ of sediment were removed from the two central units, $.94 \mathrm{~m}^{3}$ of sediment were removed from TU 3, .53 $\mathrm{m}^{3}$ from TU 4, and $.44 \mathrm{~m}^{3}$ from TU 5 . Approximately $3.75 \mathrm{~m}^{3}$ were removed in the five test units.

While Appendix D provides a more detailed discussion of the sediments in the midden, Figure 6-4 presents profiles of the two central midden units (TUs 1 and 2, top profile), and the ring unit (TU 3, bottom profile) that highlight differences in fire-cracked rock (FCR). While only larger rocks are plotted, differences in the densities of smaller fire-cracked rock are highlighted in the figures through shading. Overall, 14,870 fire-cracked rocks greater than or equal to 1 inch in size, 166 pieces of chipped stone, and 636.1 grams of mussel shell were removed from these three units. In addition to the prehistoric material, two small, very light purple fragments of glass were recovered in TU 1 at $20-30 \mathrm{~cm}$ below datum (bd). No other historic materials were noted within the midden.

All three units within the midden were excavated through the bottom of the feature (Figure 6-4). CAR personnel removed roughly $.82 \mathrm{~m}^{3}$ of midden fill from TU $1, .72 \mathrm{~m}^{3}$ of midden fill from TU 2 , and $.74 \mathrm{~m}^{3}$ of midden sediment from TU 3. Burned and fire-cracked rock and dark gray, graybrown, and occasionally black silty sediments dominated the midden fill. Charcoal was present throughout these deposits. Levels below the midden had silty sediment that was brown to yellowish-brown in color, and that was noticeably harder than the midden sediment. Fire-cracked rock and charcoal were occasionally present below the feature fill, but at a significantly lower frequency relative to midden deposits. Within the central portion of the feature, 93 chipped stone artifacts were recovered from TUs 1 and 2 , with most material recovered from Level $5(40-50 \mathrm{cmbd})$. In addition, 365.6 grams of shell were present within the two central midden units, with the highest shell weight (73.5 grams) recovered from Level $7(60-70 \mathrm{cmbd})$.

In most cases, the distinction between midden fill and underlying soil was easily made. However, in TU 3, the profile drawing suggests that the midden terminated at 70 cmbd, while the notes and the distribution of fire-cracked rock suggest that some portion of Level 8 ( $70-80 \mathrm{cmbd})$ was still within the midden. For purposes of analysis, we have included Level 8 as being within the feature deposits. The decision to include some portion of this level in the midden is supported by the results of a magnetic sediment susceptibility column taken from TU 3 (see Appendix C.). Including Level 8, the TU 3 midden deposits produced 46 chipped stone items and 243.6 grams of shell. The highest density of chipped stone was noted in Level $8(\mathrm{n}=16)$, and the highest shell weights were recorded in Level 3 (wt. $=59.6$ grams).

Charcoal was common within the midden, and was also present below the feature. Three charcoal samples were submitted to Beta Analytic for dating from the burned rock midden excavation. All three samples came from TU 3. The focus on this ring test unit for dating was related to the probable formation processes of the midden. As noted in Chapters 3 and 4, previous research on Camp Bowie burned rock middens (see Mauldin et al. 2003) has suggested that these features probably represent repeatedly used thermal features involved in the processing of geophytes. Mauldin et al. (2003) argue that the structure of these earth ovens essentially involved two elements. They suggest that there is a central thermal feature area in which multiple heating events occurred. This central area included a pit, lined with larger rock that provided thermal storage, which was then capped by earth in order to create an oven feature. The second element consists of the surrounding ring of rock. In their model (see also Black and Creel 1997; Treece 1993), the ring is generated by the cleaning out of sediment and broken rock after a given use. Broken rock should have reduced thermal storage capacity given that it has greater surface area and thus should dissipate heat faster relative to larger rock. As such, the internal portion of the feature is likely to have been frequently disturbed by subsequent use of the central area. Conversely, deposits that form the ring area are built up gradually over time. It is less likely that the ring material, once deposited, would be disturbed by subsequent heating events. Given the lower probability of disturbance, TU 3 , the ring unit on this midden, was the focus of our dating efforts. 


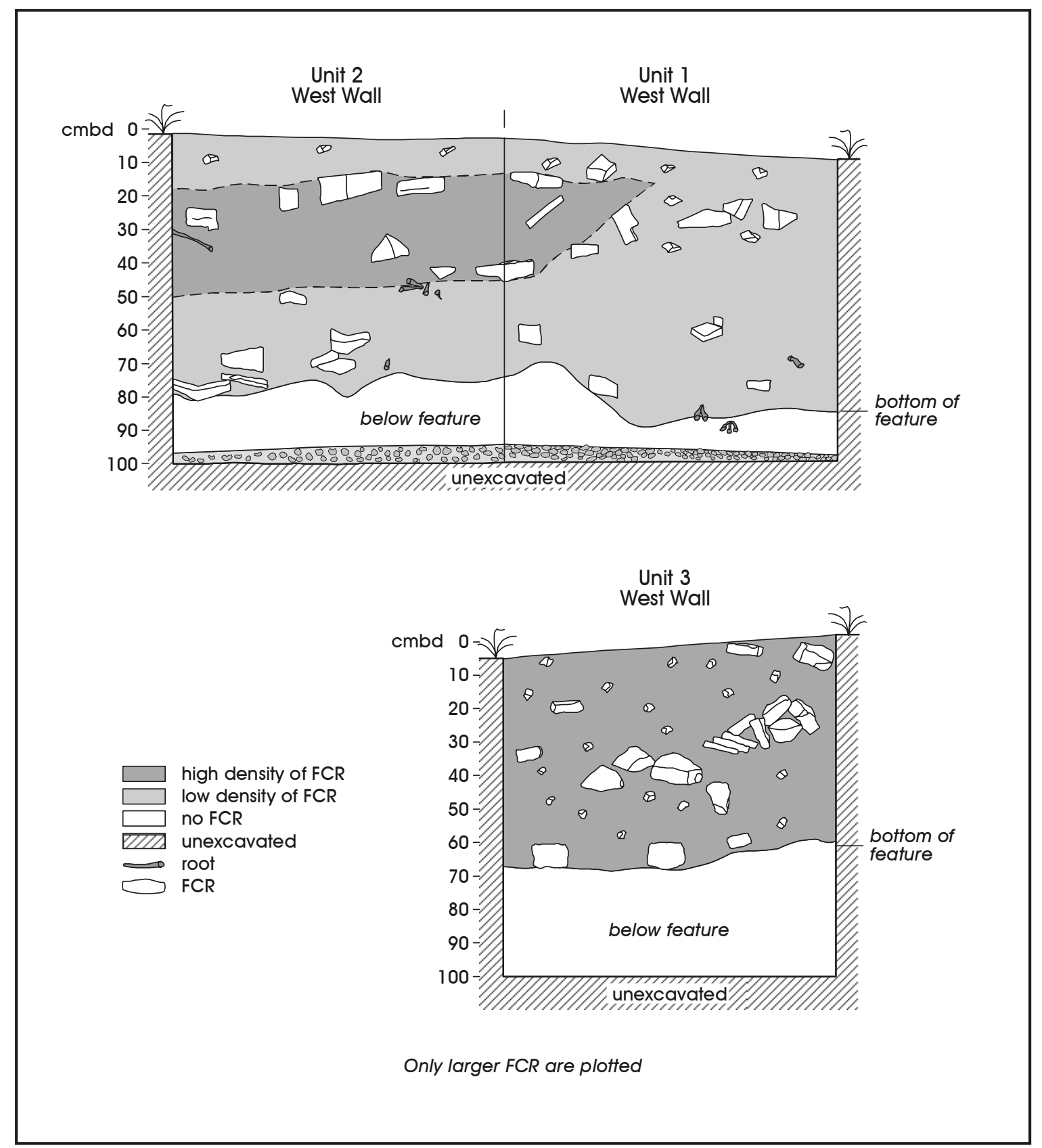

Figure 6-4. Profiles of midden test units (TUs 1-3), 41 BR392.

Three samples were selected from TU 3. One of these samples, from Level $5(40-50 \mathrm{cmbd})$, falls near the center of the midden deposit. A second sample, collected at 79 cmbd (Level 8), falls at the base of the midden. The third sample, collected from Level 10 (90-100 cmbd) falls below the midden. The resulting corrected AMS radiocarbon dates for these samples are $1110 \pm 50 \mathrm{BP}$ (Level 5), $1180 \pm 40 \mathrm{BP}$ (Level 8), and $1150 \pm 50$ BP (Level 10). Additional information on these specific dates can be found in Appendix A. Using the OxCal Calibration program (Ramsey 2000), the Level 5 date calibrates to A.D. 890-990 at 1-sigma. The Level 8 date calibrates to A.D. $770-900$ at 1-sigma. The Level 10 date calibrates to A.D. 780-980 at 1-sigma, with the highest probability area (64\%) being between A.D. 810 and A.D. 980. These dates are statistically indistinguishable. While aspects of these dates are discussed in the following 
section, if we assume that the dated material is in context and that the dated material reflects the age of the deposits in which it was found, these dates suggest the onset of midden use occurred early in the Late Prehistoric period, probably sometime around A.D. 835, with midden use terminating sometime after A.D. 940. This Late Prehistoric age for midden use is consistent both with other dates on similar features at Camp Bowie (see Mauldin and Nickels 2003), as well as with more regional patterns of burned rock midden dates (see Black and Creel 1997; Treece 1993).

A single flotation sample from TU 3, Level 5, was submitted from the midden. As outlined in Appendix B, small quantities of carbonized wood were recovered, one specimen of which was identified as mesquite. In addition, a small quantity of carbonized "slag" was present. As discussed by Mauldin et al. (2003), this material, common in middens in the Camp Bowie area, seems to be a by-product of plants, probably representing the rapid carbonization of sap. In addition, one macrobotanical sample was submitted from TU 3, Level 5, for identification. This sample was a carbonized bulb (geophyte) of an undetermined type. Bulbs are common in middens from Camp Bowie (see Dering 2003; Mauldin et al. 2003).

TU 4 was positioned near ST 10, a shovel test that produced high densities of chipped stone. Six levels, removing $.53 \mathrm{~m}^{3}$ of sediment, were excavated in this test unit. A detailed description of the sediments from this test unit, along with a profile, is provided in Appendix D (Figure D-1, Table D-1). Sediments encountered during excavations were silty, to silty clay, brown to dark brown in color, and moderately hard. This unit had high artifact densities. Two hundred and fortyone chipped stone items were recovered, including 232 pieces of debitage, one core, and eight tools. In addition, 135 grams of mussel shell were recovered from this test unit. Burned rock was not collected, but it was noted in Levels 2, 3, and 4 (10-40 cmbs). A single unburned bone, representative of an unidentified bird taxon, was recovered from Level $5(40-50 \mathrm{cmbs})$. No artifacts were recovered from Level 1, though it only contained $.03 \mathrm{~m}^{3}$ of sediment.

TU 5 was placed to the south of the burned rock midden, near ST 7, to provide data on subsurface patterns away from the midden area. Five levels, removing $.44 \mathrm{~m}^{3}$ of sediment, were excavated in this test unit. The hard, silty sediments were dark yellowish brown to a light brownish gray in color. Excavation produced 22 pieces of chipped stone debitage, and 12.1 grams of mussel shell. No burned rocks were noted in this test unit. In addition, a small fragment of stoneware, with a light tan paste and a dark brown glaze, was recovered at $10-20 \mathrm{cmbs}$. One unidentifiable, unburned mammal bone was recovered from Level $2(10-20 \mathrm{cmbs})$. No artifacts were recovered from the initial level, though that level only contained $.04 \mathrm{~m}^{3}$ of sediment. A single flotation sample, collected from Level 3 within this unit, contained no carbonized material (see Appendix B).

\section{Vertical Patterning in Material Remains from Test Units}

As was noted previously in our discussion of the shovel tests, artifacts from shovel tests excavated outside of the midden seem to primarily reflect relatively intense occupation occurring between 10 and $30 \mathrm{cmbs}$. Figure 6-5 considers the distribution of artifacts in TUs 4 and 5 in an effort to refine this pattern suggested by the shovel test data. The figure presents the percentages of chipped stone $(n=251)$ and the percentages of mussel shell weight (141.2 grams) by level for material gathered from these two non-midden units. All levels have been corrected for different amounts of sediment excavated. While the large sample of material from TU 4 dominates the combined assemblage used to create this figure, materials from both test units have roughly similar vertical distributions. Examination of the figure clearly suggests that both chipped stone and mussel shell have roughly similar distributions, with over $70 \%$ of all chipped stone (black bars) and over $60 \%$ of all shell weight (gray bars) coming from Level $3(20-30 \mathrm{cmbs})$. While the percentage of shell weight is also reasonably high (about $29 \%$ ) for Level 4, the dominance of recovery from Level 3 suggests that a single buried occupation surface may be present outside the midden.

In Appendix D, Greaves notes that an $\mathrm{AB}$ horizon is present in TU 4 between $20-30 \mathrm{cmbs}$. He suggests that the top of the $\mathrm{AB}$ horizon probably marks the prehistoric surface at the time of site occupation, an observation consistent with the patterns shown in Figure 6-5. Note that the presence of a buried surface between 20 and $30 \mathrm{cmbd}$ is further supported by magnetic sediment susceptibility values that show a distinct increase somewhere between about 25 and $28 \mathrm{cmbd}$ (see Appendix C).

The artifact distributions shown in Figure 6-5, as well as the geomorphic observations and the sediment susceptibility results, suggest that a single occupation surface, currently buried by roughly 20 to $25 \mathrm{~cm}$ of sediment, may have been the focus of prehistoric occupation at this site. Distribution of material within the midden is, not surprisingly, somewhat more complex. Here, we focus on TU 3 in the ring area of 


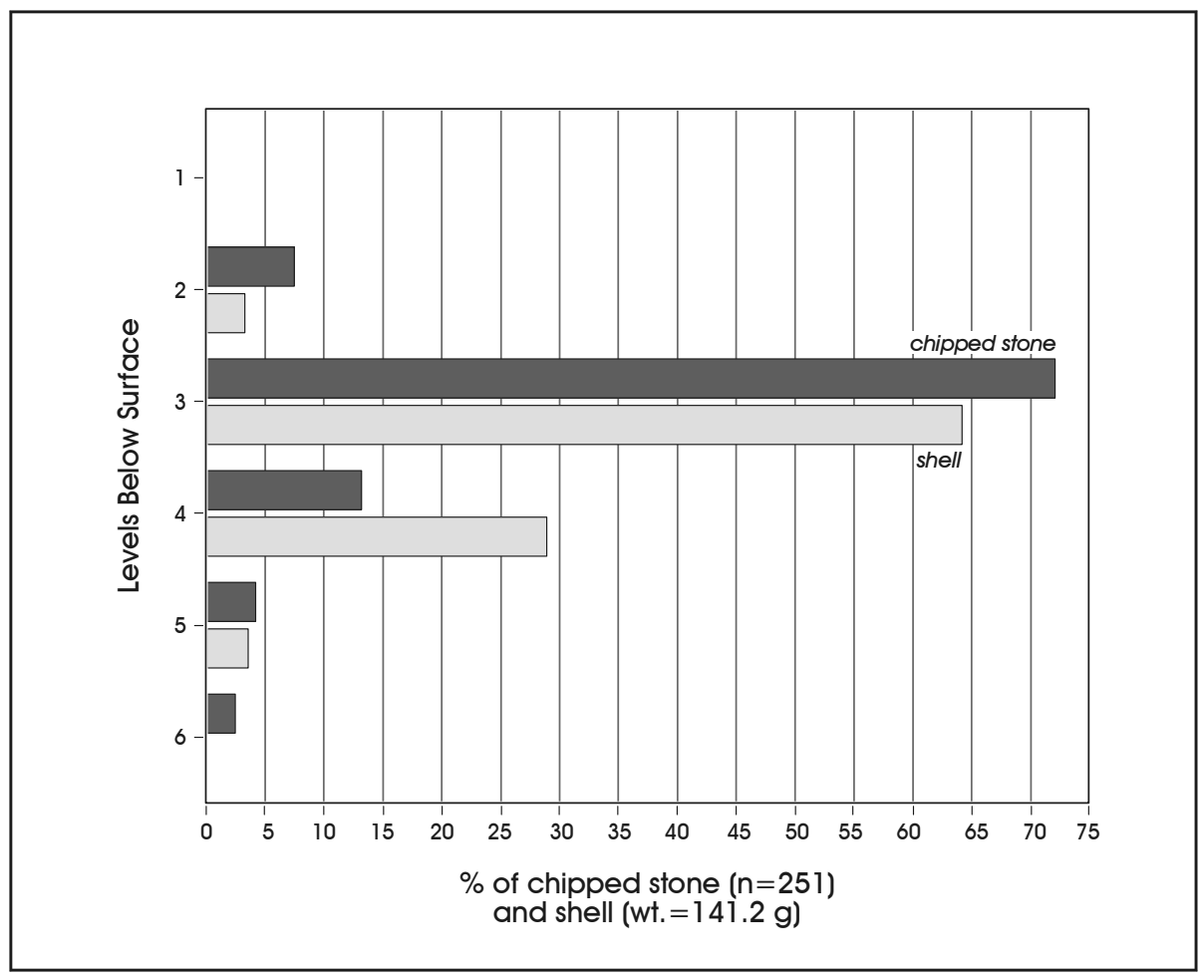

Figure 6-5. Percentages of chipped stone and mussel shell by level from non-midden test units at $41 B R 392$.

the midden. As noted in our discussion of radiocarbon sample selection, it is probable that this area has a lower frequency of disturbance when compared to the central portion of the feature.

Figure 6-6 presents vertical distribution of the percentages of the number of chipped stone debitage $(\mathrm{n}=57)$ and the weight of shell (252.9 grams) by level for TU 3. The line graph has been smoothed using a spline smoothing method in SPSS. Clearly, there is some similarity in the percentages of shell and chipped stone. The most striking elements are that both distributions have an upper peak at Level 3, a lower peak at Level 7 (shell) or 8 (debitage), and Levels 4, 5, and 6 all have lower values in both distributions. One interpretation of this graph is that there are two major periods of use reflected in the midden.

The potential that the midden material reflects two major periods of use can also be considered using burned rock data. Figure 6-7 presents standardized, smoothed curves for the number of burned rocks for three size groups by level within the midden portion of TU 3 . The standardization procedure, which transforms data into distributions with a mean of 0 and a standard deviation of 1 , allows for the plotting of radically different values on the same scale. The figure is based on 4,910 rocks between 1 and 6 inches in size, with 3,406 rocks in the 1 to 2 inch size range, 1,019 rocks in the 2 to 3 inch size range, and 485 rocks between 3 and 6 inches. Rocks less than 6 inches in size are likely to be differentially removed from the central feature area, and it may be the case that these rocks can be used as a measure of the intensity of midden use (see Mauldin et al. 2003). Examination of Figure 6-7 clearly supports two periods of more intensive midden use, a pattern that shows up in all three rock data sets presented in the figure, though the periods are reflected at slightly different levels relative to the Figure 6-6 peaks.

Finally, Figure 6-8 presents the smoothed, standardized magnetic sediment susceptibility values for the midden portion of TU 3. While additional details on magnetic sediment susceptibility (MS) can be found in Appendix C, magnetic susceptibility values are influenced by many different factors. At a general level, the value is measuring how easily a sample can be magnetized (Dearing 1999; Gose and Nickels 2001). Values appear to be primarily related to 


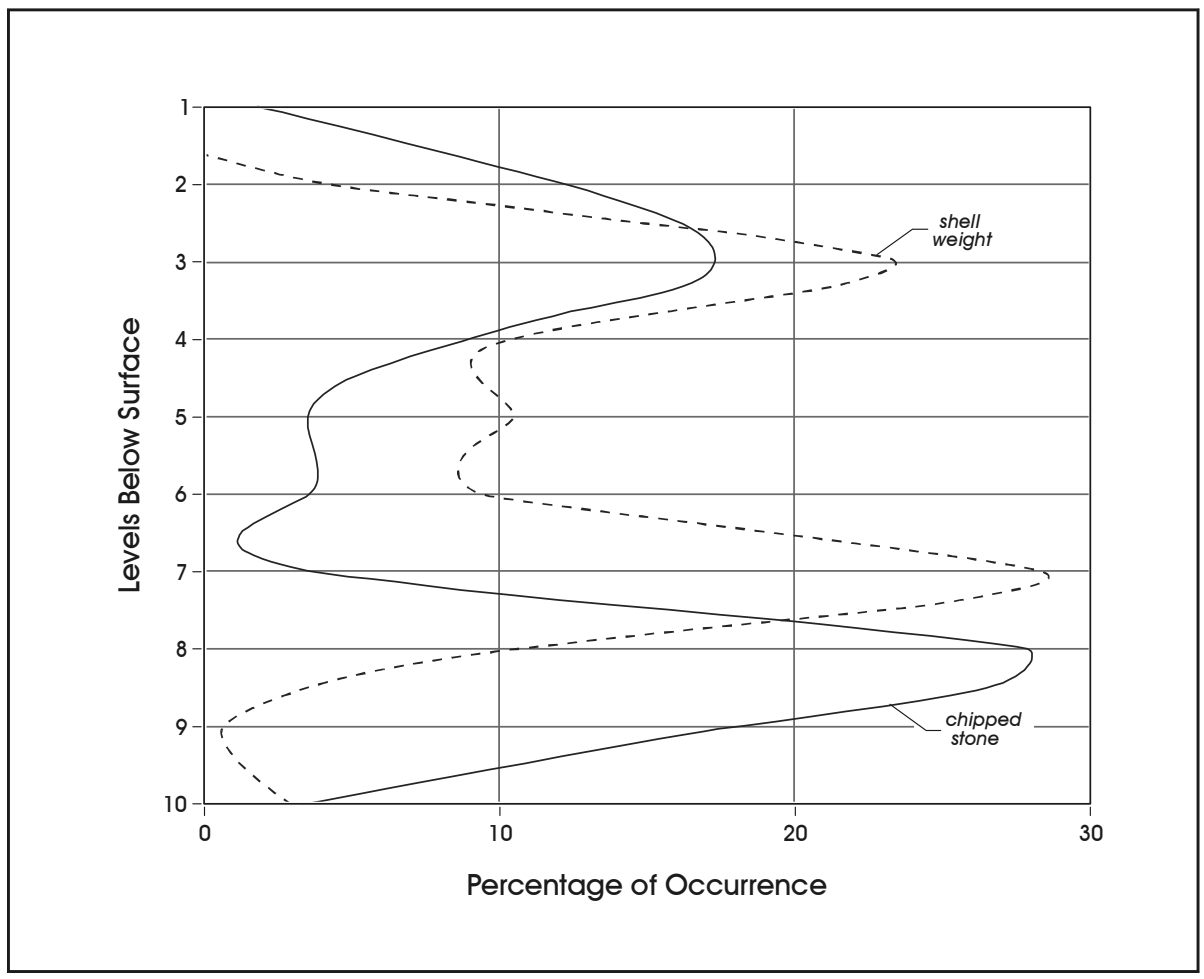

Figure 6-6. Distribution of mussel shell weight and chipped stone by level for Test Unit 3 at $41 B R 392$.

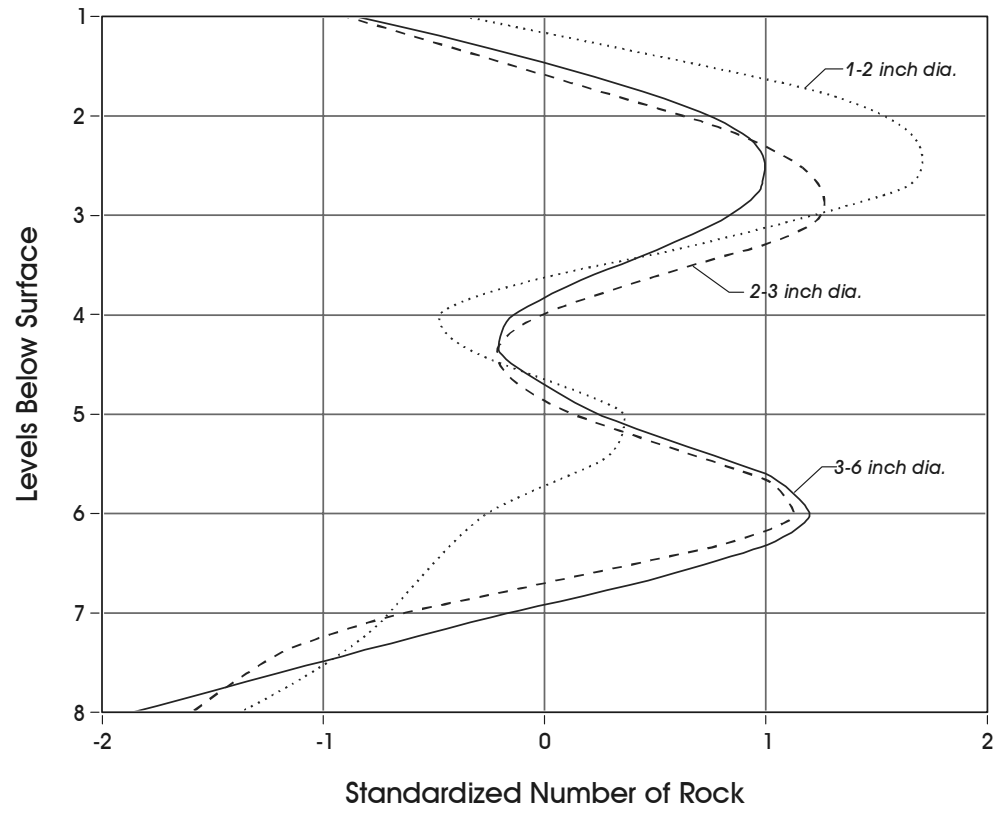

Figure 6-7. Standardized number of rocks by level for Test Unit 3 at $41 B R 392$. 


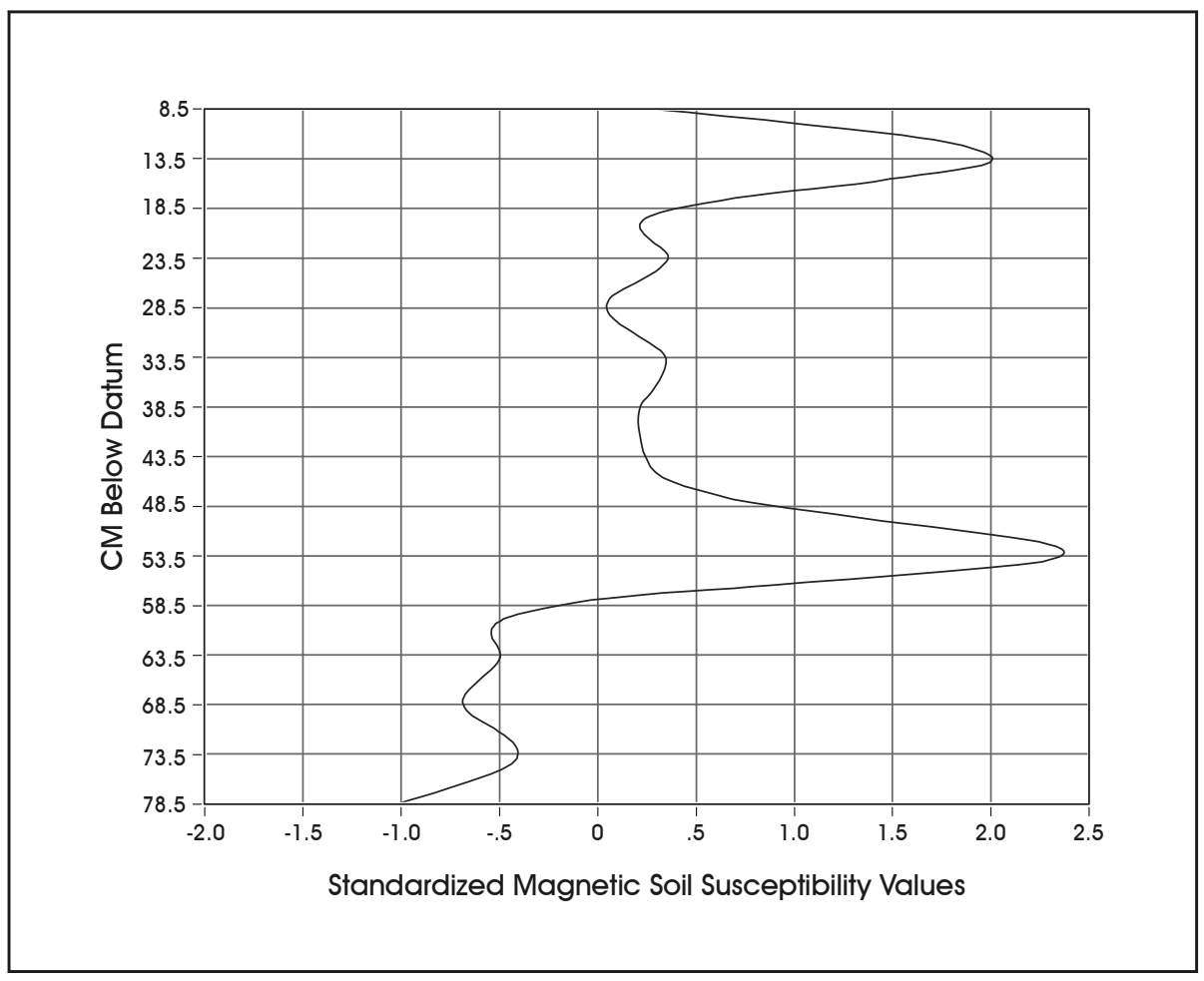

Figure 6-8. Standardized magnetic sediment susceptibility values for the midden portion of Test Unit 3 at $41 B R 392$.

the concentration and grain size of ferromagnetic and ferrimagnetic minerals in the sample (Gose and Nickels 2001). A number of processes can increase the magnetic susceptibility values in a sediment sample, including an increase in the organic constituents of sediments in a given sample (see McClean and Kean 1993; Singer and Fine 1989). Sediments with higher organic content tend to have higher magnetic susceptibility values, probably as a result of the production of maghemite, an iron oxide, during organic decay (Reynolds and King 1995). Pedogenic processes can also result in the concentration of organic material, as well as alterations in the mineralogy of a given sediment zone. Cultural processes, such as the concentration of ash, charcoal, and refuse on a surface, can also produce higher MS readings. A measure of the magnetic susceptibility of a sediment sample, then, may provide data on both the presence of surfaces, as well as a measure of the concentration of cultural activity upon those surfaces. Since the TU 3 sediments were built up by the cleaning out of the central feature area, it may be the case that periods of intensive use of the feature, which would generate a high frequency of charcoal and ash in the ring, will have higher MS values. If MS values are tracking use intensity in this setting, then the pattern in Figure 6-8 suggests that there are two periods of intensive use, one at $13.5 \mathrm{cmbd}$ (Level 2) and a second at $53.5 \mathrm{cmbd}$ (Level 5). The peaks are separated by lower but relatively consistent values between 18.5 and $48.5 \mathrm{cmbd}$, as well as lower values below $58.5 \mathrm{cmbd}$.

A variety of data sets from TU 3 , including shell weights, chipped stone debitage, burned rock in several different size ranges, and magnetic sediment susceptibility values all suggest that two periods of deposition are reflected in the midden at 41BR392. While the precise location of these peaks varies somewhat by material, an upper peak and a lower peak are reflected in all data sets. If these periods of deposition are measuring use intensity of the central feature, then clearly there are two periods reflecting intensive use. Note that the initial intensity peak probably occurs at around A.D. 890-990, based on the radiocarbon date from Level 5. The second peak, then, occurs after that date, just prior to the apparent abandonment of the feature. 


\section{Burned Rock Counts and Size Data}

As discussed previously and as summarized in Chapters 3 and 4, we propose that the burned rock middens on Camp Bowie probably represent earth ovens that are repeatedly used (Mauldin et al. 2003; see also Black and Creel 1997; Treece 1993). Figure 6-9, taken from Mauldin (2003), presents a schematic of the suggested pattern of rock replacement as a result of this repeated use. As the central feature area is maintained, broken rocks are removed to the ring area and replaced by larger rocks. This should result in 1) a greater density of medium-sized rock (i.e., 1 to 6 inches) in the ring units relative to the central units, 2) a greater density of large (6 inches or greater) rock in the central units relative to the ring, and 3) a dominance of small rocks (less than 1 inch in size) in the central feature area relative to the ring as these rocks would not be a priority for maintenance. Previous research on Camp Bowie middens has found general support for these propositions (see Mauldin 2003).

Figure 6-10 considers the first of these propositions, that fire-cracked rock in the medium size range should occur at a higher density in the ring units of midden features relative to the central units. Each of the three medium size groups (1-2 inch, 2-3 inch, 3-6 inch) are presented as separate bar graphs, and all counts have been adjusted for different volumes of sediment. For the 2-3 inch group and the 3-6 inch group, the proposition is supported. TU 3 has a higher density of rock than either TU 1 or TU 2 for both size groups. In the 1-2 inch size group, however, the ring unit (TU 3) does have a higher density than TU 1, but the highest density is found in TU 2. Figure 6-11 presents the density of larger ( 6 inches or greater) rock for the three test units. Consistent with our expectations for oven features, the central units (TUs 1 and 2) in the midden do have a higher density of larger rock relative to the ring. Finally, the weight of smaller (less than 1 inch) rock per cubic meter is shown in Figure 6-12. The expectation that these smaller rocks should be more frequent in the interior units is supported. The internal units, then, have higher densities of larger rock, higher weights of smaller rock, and lower densities of rock in the 2-3 and 3-6 inch size ranges when compared to the ring unit. While density expectations in the 1-2 inch size range are only partially supported by the data, the overall pattern in burned rock within this midden is consistent with the expectations that the feature was used as an earth oven.

\section{The Chipped Stone Assemblage}

A variety of chipped stone material was recovered from shovel testing and test excavations at 41BR392, including nine bifaces, two unifaces, and 497 pieces of debitage. The debitage and tool assemblage seems to suggest a focus on late stage bifacial reduction activities, though the patterns in debitage are not clear-cut.

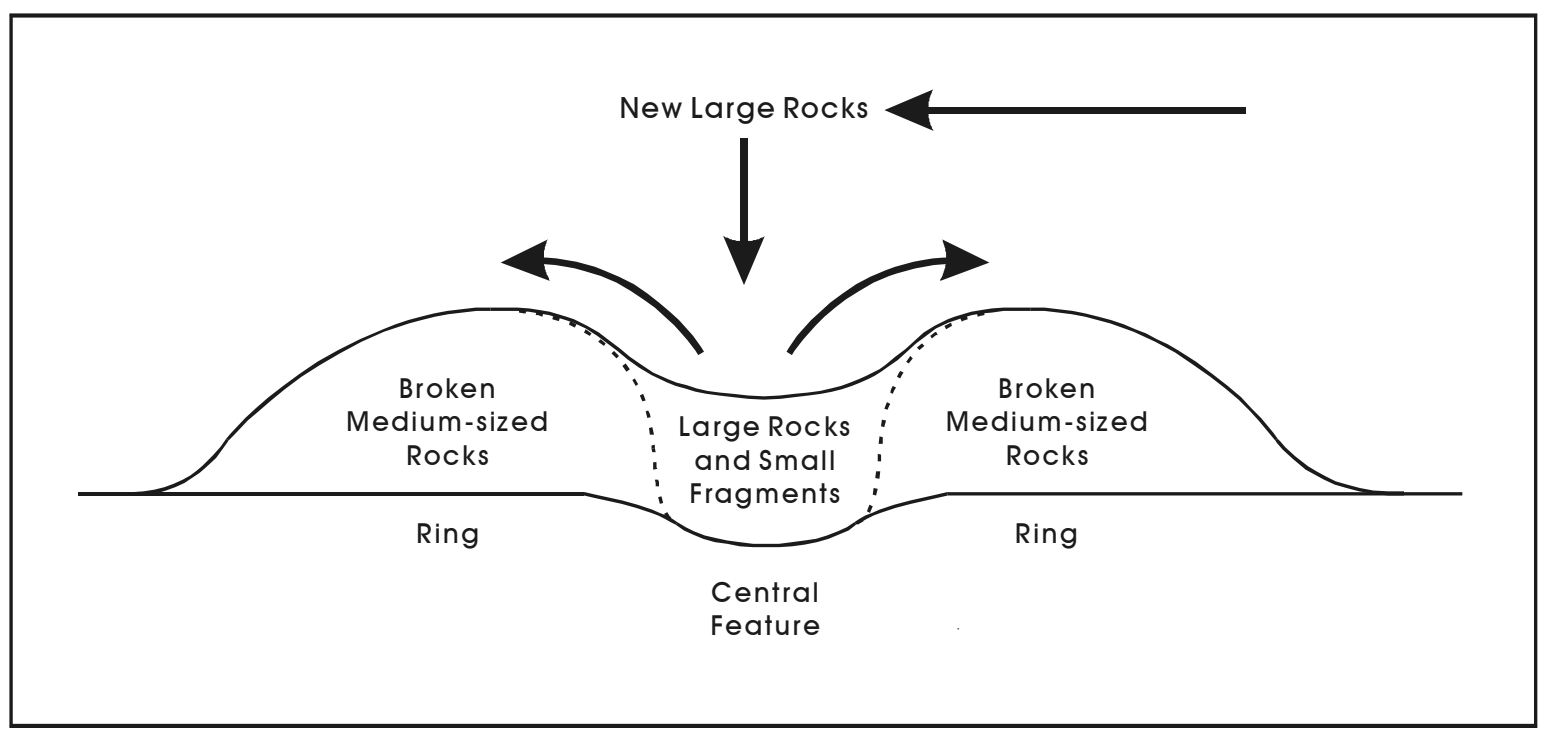

Figure 6-9. Earth oven model of midden formation. 


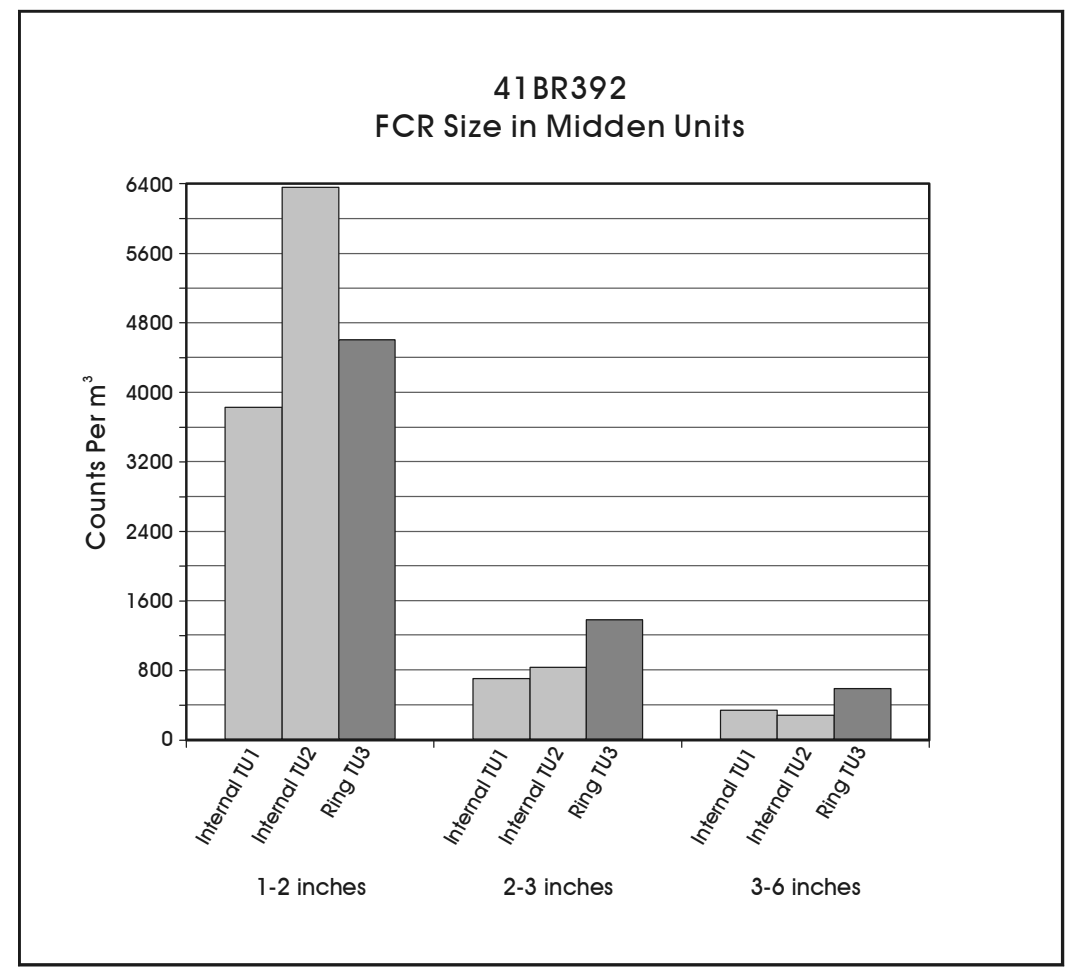

Figure 6-10. Distribution of medium-sized rock groups by unit within the burned rock midden at $41 B R 392$.

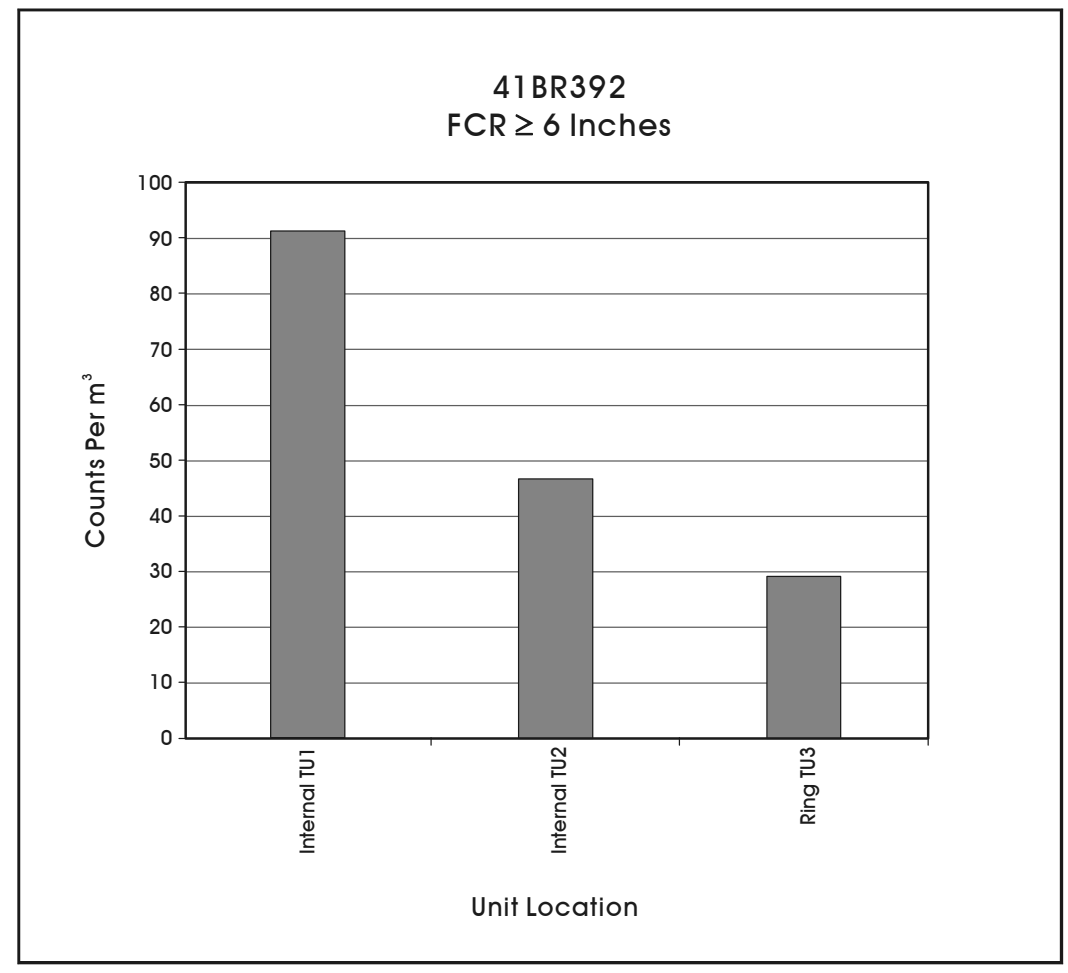

Figure 6-11. Distribution of burned rock (6 inches or greater) by test unit for midden units at $41 B R 392$. 


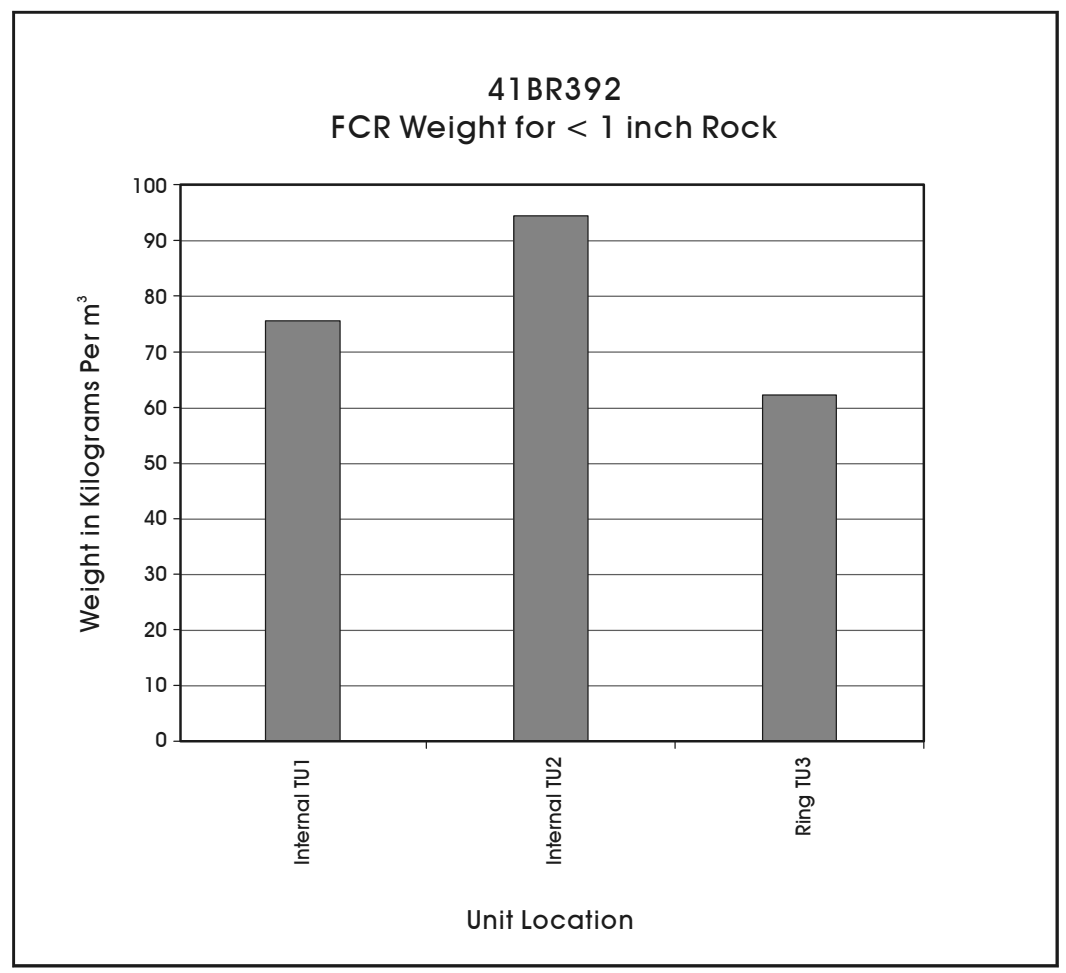

Figure 6-12. Weight of small ( $<1$ inch) burned rock by test unit at 41 BR392.

\section{Debitage Patterns}

Cortex was absent on $75 \%$ of the debitage $(n=374)$, while only 28 items (5.6\%) had more than $50 \%$ dorsal cortex cover. Table 6-1 presents the cortex patterns at this site and contrasts them to the combined collections from the remaining three sites tested on this project. Also included in the table are the standardized adjusted residuals. Briefly, standardized adjusted residuals measure the contribution of each individual cell to the overall significance of a contingency table (see Everitt 1977; Haberman 1973). Adjusted residual values are analogous to $\mathrm{Z}$ scores, such that a cell with an adjusted residual exceeding an absolute value of 1.96 suggests that this cell is significantly different at a probability exceeding .05 (see Everitt 1977). Focusing on the standardized adjusted residual values, note that none of the cells are significantly different. While $75 \%$ non-cortical flakes clearly suggests activity late in the reduction sequence, the patterns of cortex at this site are not significantly different from the combined assemblages from the remaining three sites.

Table 6-1. Counts and Adjusted Residual Values for Cortex Patterns, 41BR392 and Remaining Sites

\begin{tabular}{|c|c|c|c|c|c|c|}
\hline & \multicolumn{3}{|c|}{ Cortex } & \multirow{2}{*}{$\begin{array}{c}\text { Total } \\
\text { Counts } \\
\end{array}$} & \multirow[b]{2}{*}{ Percentage } \\
\hline & & $0 \%$ & $1-50 \%$ & $51-100 \%$ & & \\
\hline All Other & Raw Counts & 867 & 209 & 62 & 1138 & $69.6 \%$ \\
\hline Sites & Adjusted Residual & 0.42 & -0.37 & -0.16 & & \\
\hline \multirow[t]{4}{*}{ 41BR392 } & Raw Counts & 374 & 95 & 28 & 497 & $30.4 \%$ \\
\hline & Adjusted Residual & -0.42 & 0.37 & 0.16 & & \\
\hline & Total Counts & 1241 & 304 & 90 & 1635 & \\
\hline & Percentage & $75.9 \%$ & $18.6 \%$ & $5.5 \%$ & & \\
\hline
\end{tabular}


Table 6-2. Counts and Adjusted Residual Values for Flake Types, 41BR392 and Remaining Sites

\begin{tabular}{|c|c|c|c|c|c|c|c|c|}
\hline & & \multicolumn{5}{|c|}{ Flake Types } & \multirow[b]{2}{*}{$\begin{array}{c}\text { Total } \\
\text { Counts } \\
\end{array}$} & \multirow[b]{2}{*}{ Percentage } \\
\hline & & $\begin{array}{l}\text { Angular } \\
\text { Debris } \\
\end{array}$ & $\begin{array}{l}\text { Biface } \\
\text { Manufacturing }\end{array}$ & $\begin{array}{l}\text { Biface } \\
\text { Thinning }\end{array}$ & \begin{tabular}{|l} 
Core \\
Preparation \\
\end{tabular} & \begin{tabular}{|l} 
Platform \\
Preparation
\end{tabular} & & \\
\hline $\begin{array}{l}\text { All Other } \\
\text { Sites }\end{array}$ & $\begin{array}{l}\text { Raw Counts } \\
\text { Adjusted Residual }\end{array}$ & \begin{tabular}{|c|}
37 \\
-1.01 \\
\end{tabular} & \begin{tabular}{|c|}
79 \\
-1.63 \\
\end{tabular} & \begin{tabular}{|c|}
14 \\
-5.00 \\
\end{tabular} & \begin{tabular}{|c|}
12 \\
1.26 \\
\end{tabular} & \begin{tabular}{|l|}
317 \\
4.11 \\
\end{tabular} & 459 & $64.6 \%$ \\
\hline \multirow[t]{3}{*}{ 41BR392 } & $\begin{array}{l}\text { Raw Counts } \\
\text { Adjusted Residual }\end{array}$ & $\begin{array}{c}26 \\
1.01 \\
\end{array}$ & $\begin{array}{c}56 \\
1.63 \\
\end{array}$ & $\begin{array}{c}32 \\
5.00 \\
\end{array}$ & $\begin{array}{c}3 \\
-1.26 \\
\end{array}$ & $\begin{array}{r}135 \\
-4.11 \\
\end{array}$ & 252 & $35.4 \%$ \\
\hline & Total Counts & 63 & 135 & 46 & 15 & 452 & 711 & \\
\hline & Percentage & $8.9 \%$ & $18.9 \%$ & $6.5 \%$ & $2.1 \%$ & $63.6 \%$ & & \\
\hline
\end{tabular}

The possibility that the 41BR392 assemblage reflects late stage reduction is also supported by the thickness/length ratio for the 147 complete flakes. The site ratio is .184 . Values greater than .26 probably reflect a focus on early stage reduction.

Table 6-2 presents the division of flakes by flake type. Five flake types are used in the table. These are platform preparation flakes, biface thinning flakes, biface manufacturing flakes, core preparation flakes, and angular debris (see Tomka 2002). Platform preparation flakes may be indicative of bifacial reduction, though some form of core reduction can also result in a high frequency of these flakes. Bifacial reduction is clearly indicated by the presence of biface thinning flakes, as well as biface manufacturing flakes. Core preparation flakes are directly reflective of core reduction. Finally, angular debris flakes are frequently high during some forms of core reduction. As with Table 6-1, we contrast the 41BR392 assemblage with the combined assemblage generated from the remaining three sites. Examination of the adjusted residuals shows that there are significant differences in the number of biface thinning and platform preparation flakes, with biface thinning flakes being significantly over-represented and platform preparation flakes significantly under-represented. Biface thinning flakes clearly reflect late stage bifacial work at this location. While the interpretation of the platform preparation flake category is more ambiguous, this category may also contain a significant component of material generated from bifacial reduction. The significant under-representation of these flakes, then, is in contrast to the over-representation of the biface thinning group. Given that biface manufacturing flakes are over-represented and that core preparation flakes are under-represented (Table 6-2), the assemblage probably reflects a predominance of bifacial reduction relative to core reduction. However, the difference in the number of biface manufacturing and core preparation flakes at this site is not significant when contrasted to the other assemblages. In addition, cores were not recovered from 41BR392, though as outlined in the following section, bifacial and unifacial tools were present in the tool assemblage.

Finally, note that there are significant differences in the frequency of heating observed on debitage collected from the midden relative to non-midden areas. Evidence of heating was present on only $18 \%$ of the debitage ( 60 of 333 pieces) examined from outside of the midden. Conversely, heating was observed on $32.5 \%(n=53)$ of the flakes examined from within the midden. The midden debitage was probably an incidental incorporation into the feature as sediment, taken from the ground surrounding the midden, was added as an earthen cap (see Leach and Bousman 2001; Mauldin et al. 2003).

\section{Tools}

Figure 6-13 shows the 11 tools recovered from this site. These include two unifaces (6-13a and 6-13b) and nine bifaces (6-13c through 6-13k). The bifaces are generally late stage specimens, and at least one biface (6-13f) exhibits heat cracks. This specimen was recovered from the midden. Most of the material came from TU 4, including seven bifaces (6-13c through 6-13i). Another biface (6-13j) is a well-thinned proximal fragment with pressure flaking along the edges and was probably a finished tool before breakage. 


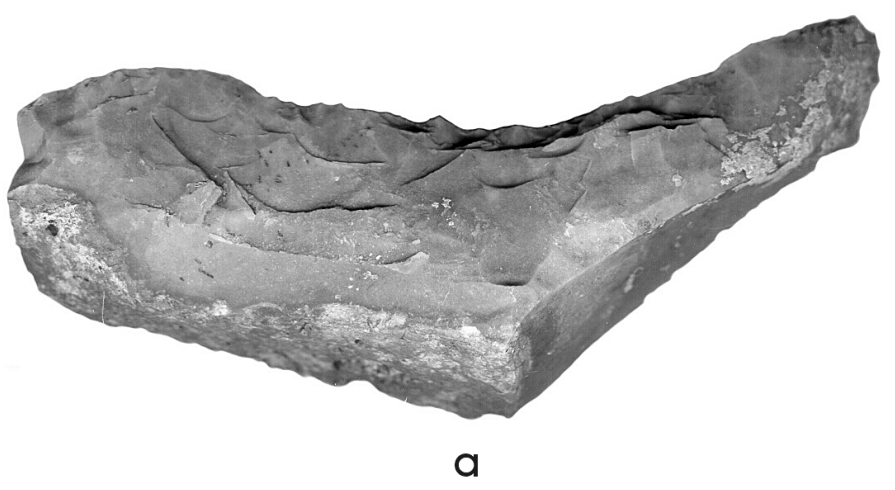

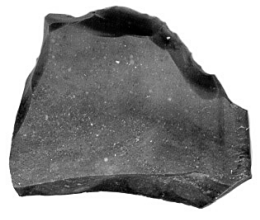

b

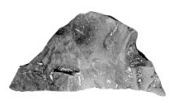

C

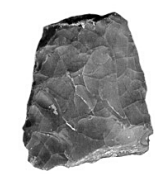

d

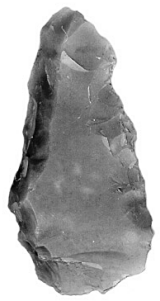

$\mathrm{h}$

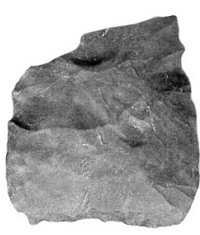

e

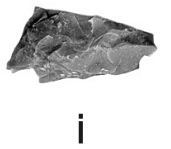

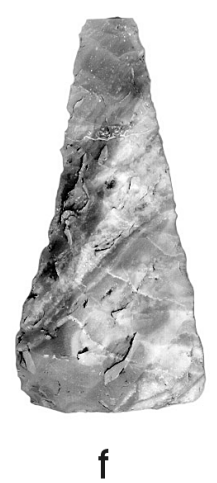

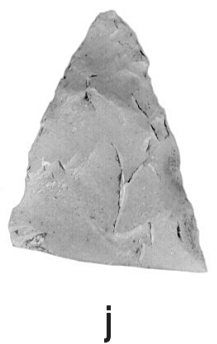

j
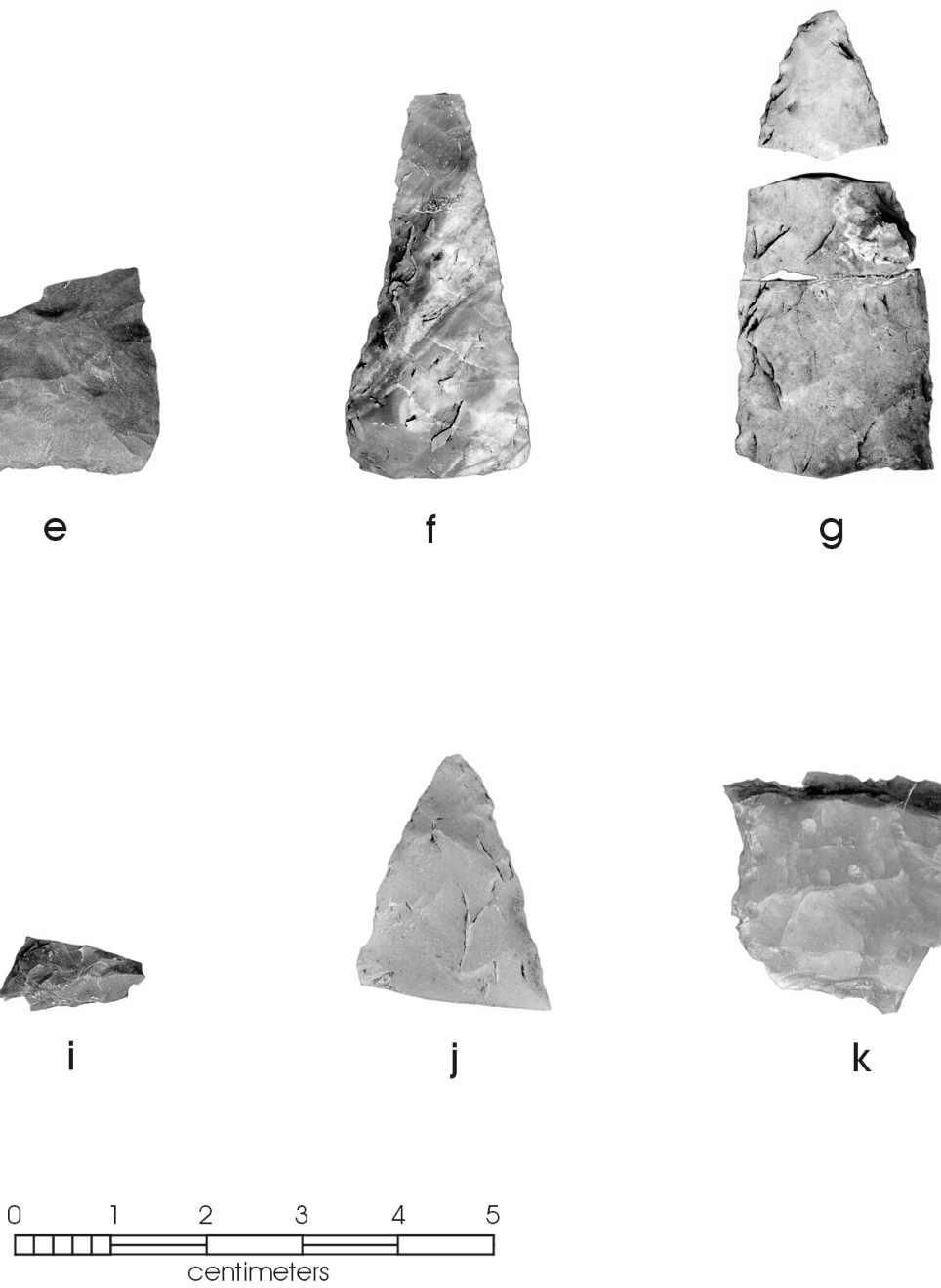

Figure 6-13. Tools recovered from 41BR392. a-b) unifaces; $\mathrm{c}-\mathrm{k}$ ) bifaces. 


\section{Summary}

Site 41BR392 was originally described by Wormser and Sullo-Prewitt (2001) as a historic site. Greaves (2002:3032) documented a large ( $12 \mathrm{~m} \times 15 \mathrm{~m} \times .6 \mathrm{~m})$, oval sandstone burned rock midden with a low central depression at this site. Two shovel tests confirmed the prehistoric nature of the midden. A single Bulverde point, manufactured during the late Middle Archaic or the early Late Archaic, was collected from the surface (Greaves 2002:32). On the basis of the burned rock midden, Greaves (2002) recommended that testing, focused on this prehistoric feature, should be conducted to clarify the eligibility status of this site. Both shovel tests and test excavation units were placed on 41BR392. CAR's most recent work at this site produced over 500 pieces of chipped stone, including several bifaces and two unifaces. This assemblage is somewhat consistent with late-stage biface reduction. In addition, mussel shell was collected from a variety of different locations, and CAR measured sizes on roughly 15,000 pieces of burned rock from the midden feature.

Patterning in shovel test data suggests that most material was present around the midden, with low densities away from the feature. Vertical distribution in the chipped stone and shell, as well as observations on fire-cracked rock, suggest that deposits were primarily found from 20 to 40 cmbs. Patterning in the distribution of chipped stone and mussel shell in the two non-midden test units refined the vertical distribution identified in the shovel tests. The vertical distribution of material suggests a single occupation surface, between 20 and $30 \mathrm{cmbs}$, was present at this site. This location was consistent with geomorphic observations and was further supported by data provided by magnetic sediment susceptibility samples.

An analysis of burned rock sizes within the midden is consistent with the earth oven model in which large rocks are used as heating elements and smaller, fractured rocks are discarded to the exterior ring. Vertical distribution of debitage, burned rock, shell, and magnetic sediment susceptibility values in the single excavation unit placed within the ring portion of the midden suggests that there were two periods of intensive midden use. Neither of these periods of midden use can be clearly associated with the outside occupation surface. Radiocarbon dates demonstrate that one of these periods of intensive use was sometime between A.D. 890 and A.D. 990, with a second, later intensive period of use also noted. An additional radiocarbon date from the base of the feature suggests that the midden began to form around A.D. 770-900. Given these results, the single Bulverde point collected from the surface during the previous work at this site (Greaves 2002) is out of context and probably does not reflect any significant Archaic period occupation at the location. Ethnobotanical remains were present in the midden, and though limited, these data are consistent with a focus on the processing of geophytes in this earth oven feature.

Finally, note that while there is a historical component on the site, and while a rock wall associated with that component has impacted the northern edge of the feature, historic artifacts were not common in either the shovel tests or in the test excavations. It is our assessment that the burned rock midden at 41BR392 remains largely intact and that buried off-midden deposits, probably representing a single surface with occupation, are present. 


\title{
Chapter 7: $\quad$ Testing Results at Site 41BR47 I
}

\author{
Jason D. Weston and Raymond P. Mauldin
}

In this chapter, the results of the testing performed at site 41BR471 are discussed. Findings concerning all shovel testing and surface collection efforts, including a discussion of all artifacts collected, are provided.

\section{Site 41BR471}

Previous research at site 41BR471 (Greaves 2002:26-30) characterized this site as a predominantly low-density surface scatter of prehistoric artifacts. However, two higher density areas, a small area located to the north and a larger area near the center of the site, were noted. Figure 7-1, a blow-up of the central and northern sections on the site, identifies these two areas. Four shovel tests, one of which (ST 1) recovered a single piece of debitage from $0-10 \mathrm{~cm}$ below surface, were placed at the site (see Figure 7-1). In addition to the shovel tests and identification of the surface concentrations, Figure 7-1 also identifies the locations of a Late Prehistoric projectile point and a multi-directional core collected during the initial work (see Greaves 2002:26-30).

As outlined in the methods chapter, during this project site 41BR471 was tested using six controlled surface collection areas (identified as dog leashes or "DL"). These collection areas were circles with a radius of $1 \mathrm{~m}$ resulting in an area of roughly $3.14 \mathrm{~m}^{2}$. Figure 7-2 presents the locations of these collection areas. Four of the six collection areas (DL 1 through DL 4) were placed in the central surface concentration, while DL 5 was placed in the smaller, northern concentration. DL 6 was placed outside the high-density areas to explore debitage noted on the surface at that location (Figure 7-2).

In addition to the surface collection areas, two test units were excavated to check for the presence of buried deposits (Figure 7-2). As bedrock was exposed on the surface of the northern high-density area, TU 1 was placed in the area of DL 6. This area seemed to have the potential for deeper deposits. TU 2 was placed in the northern concentration, within the footprint of DL 5. TU 1 was excavated to a depth of $40 \mathrm{cmbs}$. TU 2 was excavated to a depth of between 54 and $58 \mathrm{cmbs}$. Both units were terminated when the underlying sandstone bedrock was encountered.

\section{Surface Collection and Testing Results}

The six surface collection areas, covering a combined area of roughly $18.84 \mathrm{~m}^{2}$, recovered 30 items, an overall density of only 1.59 items per square meter. The 30 items included 22 pieces of debitage, four cores, a uniface, and three burned rocks. The highest recovery was in DL 6, with nine items collected (about 2.87 items per square meter). The lowest recovery rate was in DLs 1 and 3, both of which had only three items. TU 1 produced no artifacts. TU 2 recovered only three pieces of debitage. One item was recovered from Level $1(0-10 \mathrm{cmbs})$, and the remaining two items came from Level $2(10-20 \mathrm{cmbs})$.

From the six surface collection areas and two test units, then, 25 unmodified lithic debitage, four cores, a unifacial tool (possible scraper), and three burned rocks were recovered. No features were present at the site, though the recovery of three burned rocks, collected from two different surface collection areas on this site, suggests that some sort of thermal activity was conducted at this location. The surface collection accounted for $88 \%(\mathrm{n}=22)$ of the debitage collected, and $91 \%(n=30)$ of all material recovered. This low subsurface recovery supports the first assessment of the site that there was little chance of well preserved or deeply buried deposits (Greaves 2002:28). What remains is essentially a surface site, possibly in the process of eroding.

\section{The Chipped Stone Assemblage}

The debitage from the site seems to suggest early reduction activities. While the overall number of debitage recovered is low $(\mathrm{n}=25)$, only five items $(20 \%)$ lacked cortex. Twelve pieces of debitage (48\%) had $1-50 \%$ cortex present, and eight $(32 \%)$ had over $50 \%$ cortex present on the dorsal surface. Table 7-1 presents these cortex patterns at this site and contrasts them to the 1,610 pieces of debitage with cortex percentages from the remaining three sites. Also included in the table are the standardized adjusted residuals. As outlined in the previous chapter, standardized adjusted residuals measure the contribution of each individual cell to the overall significance of a contingency table (see Everitt 1977; Haberman 1973). A cell with an adjusted residual 


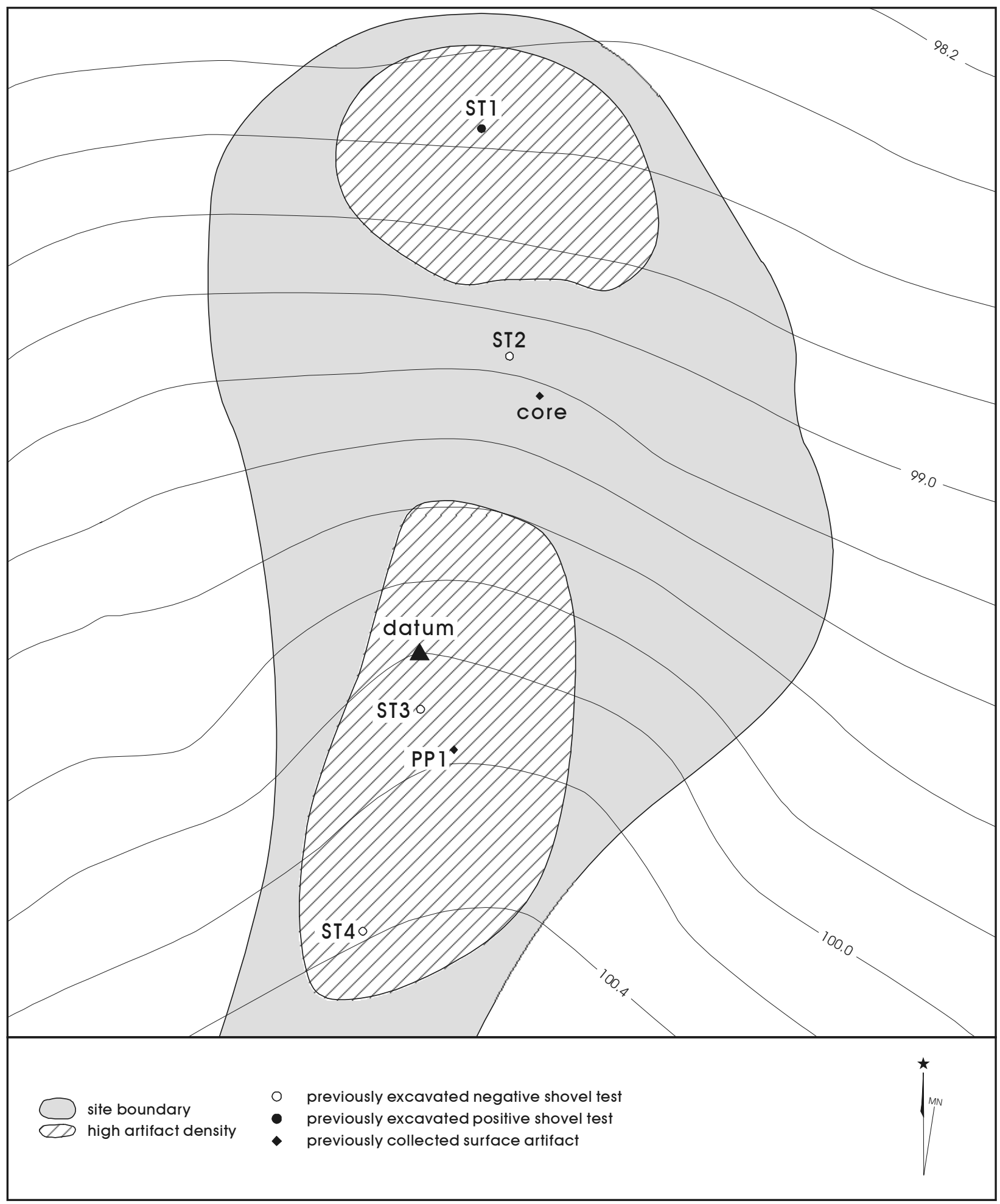

Figure 7-1. Close-up of site 41BR471 showing previous work. 


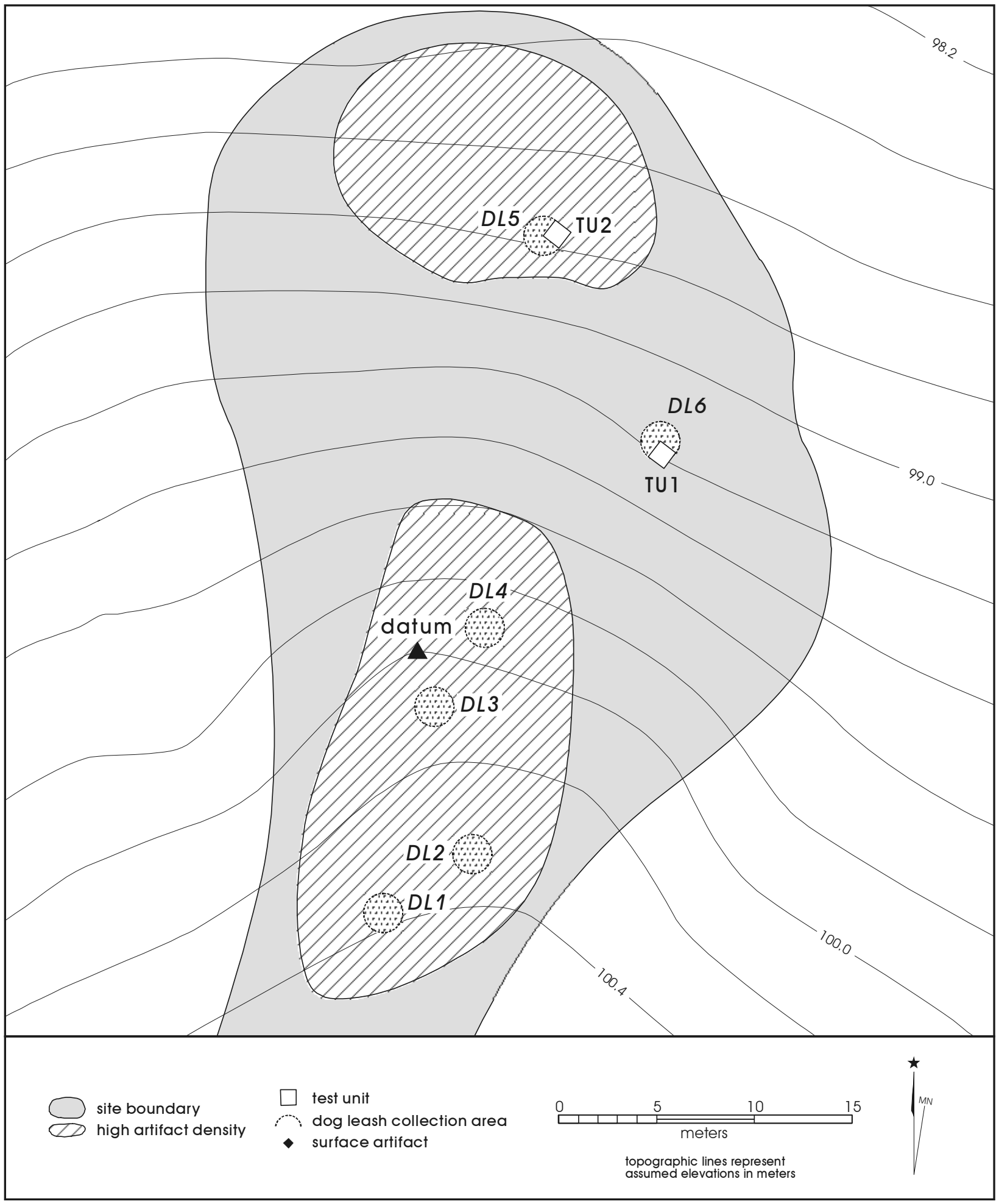

Figure 7-2. Locations of test units and collection areas at $41 B R 471$. 
exceeding an absolute value of 1.96 suggests that this cell is significantly different at a probability exceeding .05 (see Everitt 1977). It is clear from the standardized adjusted residual values that the patterns of cortex at 41BR471 are significantly different from the combined collection of the remaining sites in all three categories. 41BR471 has significantly fewer tertiary $(0 \%$ cortex $)$ flakes, and significantly more flakes with cortex when compared to the remaining site assemblages from this project.

The thickness/length ratio of complete flakes supports this assessment of early reduction. While only eight complete flakes are present in the assemblage, the mean thickness/ length ratio is .31 . Ratios greater than .26 probably indicate late stage reduction. Note also that the ratio for the remaining 366 complete flakes from the other three sites averages 190 .

Debitage flake type analysis results are presented in Table 7-2. Platform preparation flakes $(n=6)$, core preparation flakes ( $\mathrm{n}=4)$, and angular debris $(\mathrm{n}=3)$ accounted for $100 \%$ of the classified debitage. No biface thinning or biface manufacturing flakes were identified in the assemblage. While some of the platform preparation flakes may be indicative of bifacial work, these patterns are consistent with early stage reduction suggested by the cortex and thickness/ length ratio. The strength of this pattern is evident in Table $7-2$, which contrasts the flake type patterns for 41BR471 to the remaining sites. We have eliminated indeterminate flakes from the table. We have also eliminated four flakes classified as "other" flakes types. These included a single blade, two uniface manufacturing flakes, and one overshot flake. The remaining flakes fall into five categories and the total sample size is 711 pieces of debitage. As with Table 7-1, below the raw counts are the standardized adjusted residuals. Examination of the cell adjusted residuals in Table 7-2 will demonstrate that significant differences between 41BR471 and the remaining three sites are only present in the core preparation cells, with 41BR471 having significantly more of these flakes. In fact, while the classifiable assemblage for 41BR471 accounts for only $1.8 \%$ of the 711 flakes, the site contains $26.7 \%$ of all core preparation flakes. Consistent with this pattern is the observation that five cores and only two tools have been collected from this site during the two projects.

The debitage, as well as the limited core and tool assemblage, clearly suggests that the site is dominated by early reduction activities. Recall, however, that these conclusions are based

Table 7-1. Counts and Adjusted Residual Values for Cortex Patterns, 41BR471 and Remaining Sites

\begin{tabular}{|c|c|c|c|c|c|c|}
\hline & & \multicolumn{3}{|c|}{ Cortex Percentage } & \multirow[b]{2}{*}{ Total Count } & \multirow[b]{2}{*}{ Percentage } \\
\hline & & $0 \%$ & $1-50 \%$ & $51-100 \%$ & & \\
\hline $\begin{array}{l}\text { All Other } \\
\text { Sites }\end{array}$ & $\begin{array}{l}\text { Raw Count } \\
\text { Adjusted Residual }\end{array}$ & $\begin{array}{c}1236 \\
6.59 \\
\end{array}$ & $\begin{array}{r}292 \\
-3.81 \\
\end{array}$ & $\begin{array}{r}82 \\
-5.85 \\
\end{array}$ & 1610 & $98.48 \%$ \\
\hline \multirow[t]{3}{*}{ 41BR471 } & $\begin{array}{l}\text { Raw Count } \\
\text { Adjusted Residual }\end{array}$ & $\begin{array}{r}5 \\
-6.59 \\
\end{array}$ & $\begin{array}{c}12 \\
3.81 \\
\end{array}$ & $\begin{array}{c}8 \\
5.85 \\
\end{array}$ & 25 & $1.53 \%$ \\
\hline & Total Count & 1241 & 304 & 90 & 1635 & \\
\hline & Percentage & $75.90 \%$ & $18.59 \%$ & $5.50 \%$ & & \\
\hline
\end{tabular}

Table 7-2. Counts and Adjusted Residual Values for Flake Types, 41BR471 and Remaining Sites

\begin{tabular}{|c|c|c|c|c|c|c|c|c|}
\hline & \multicolumn{5}{|c|}{ Flake Types } & \multirow[b]{2}{*}{$\begin{array}{c}\text { Total } \\
\text { Counts } \\
\end{array}$} & \multirow[b]{2}{*}{ Percentage } \\
\hline & & $\begin{array}{l}\text { Angular } \\
\text { Debris }\end{array}$ & $\begin{array}{c}\text { Biface } \\
\text { Manufacture }\end{array}$ & $\begin{array}{c}\text { Biface } \\
\text { Thinning }\end{array}$ & $\begin{array}{c}\text { Core } \\
\text { Preparation }\end{array}$ & $\begin{array}{l}\text { Platform } \\
\text { Preparation }\end{array}$ & & \\
\hline $\begin{array}{l}\text { All Other } \\
\text { Sites }\end{array}$ & $\begin{array}{l}\text { Raw Counts } \\
\text { Adjusted Residual }\end{array}$ & $\begin{array}{c}60 \\
-1.82\end{array}$ & $\begin{array}{l}135 \\
1.76\end{array}$ & $\begin{array}{c}46 \\
0.96\end{array}$ & $\begin{array}{c}11 \\
-7.26\end{array}$ & $\begin{array}{l}446 \\
1.32\end{array}$ & 698 & $98.20 \%$ \\
\hline \multirow[t]{3}{*}{ 41BR471 } & $\begin{array}{l}\text { Raw Counts } \\
\text { Adjusted Residual }\end{array}$ & $\begin{array}{c}3 \\
1.82 \\
\end{array}$ & $\begin{array}{c}0 \\
-1.76 \\
\end{array}$ & $\begin{array}{c}0 \\
-0.96 \\
\end{array}$ & $\begin{array}{c}4 \\
7.26 \\
\end{array}$ & $\begin{array}{c}6 \\
-1.32 \\
\end{array}$ & 13 & $1.80 \%$ \\
\hline & Total Counts & 63 & 135 & 46 & 15 & 452 & 711 & \\
\hline & Percentage & $8.9 \%$ & $18.9 \%$ & $6.5 \%$ & $2.1 \%$ & $63.6 \%$ & & \\
\hline
\end{tabular}


on small sample sizes. This makes any evaluation of the lithic technology at this site potentially unreliable. In addition, note that the context of the recovered material, being dominated by surface finds, may also impact any assessment by conditioning the size of the material recovered. As Mauldin and Nickels (2001:14-21; see also Mauldin 1995:83-97, 2001:110-120) have demonstrated, the recovery context (e.g., surface $v s$. subsurface) can influence the size of the material collected, and size often is correlated with different types of artifacts. Surface artifacts tend to be larger in size relative to subsurface artifacts in most settings, and larger artifacts tend to be reflective of early stage reduction. However, given the strength of the patterns documented above, we submit that early stage reduction, potentially focused on cores rather than bifaces, dominated the chipped stone reduction activities at 41BR471.

\section{Summary}

A small amount of debitage $(\mathrm{n}=25)$, four cores and a single tool (a scraper) were recovered from 41BR471 during this testing project. The cores and debitage indicate that early stage reduction was the main lithic activity at the site but the small sample size makes a positive determination of the range of flintknapping and other activities difficult. Surface collection accounts for nearly all of the artifacts with only three pieces of debitage recovered from test units. The site is a heavily degraded surface scatter with a minimal, shallowly buried element. No features were discovered, and no charcoal, faunal, or ethnobotanical data were collected. In addition, no new diagnostic artifacts were recovered. 



\title{
Chapter 8: $\quad$ Testing Results at Site 41BR500
}

\author{
Jason D. Weston and Raymond P. Mauldin
}

In this chapter we discuss the results of the testing performed at site 41BR500. Findings concerning all shovel testing and test excavations are outlined. In addition, details of all artifacts and radiocarbon and ethnobotanical analyses are provided.

\section{Site $41 B R 500$}

41BR500 is a moderately sized site (about 12,190 $\mathrm{m}^{2}$ ) consisting of a scatter of chipped stone debitage, several bifaces, unifaces, ground stone, two projectile points, and scattered burned rock (Mauldin and Broehm 2001:21). Roughly two-thirds of the site has been disturbed by plowing, as well as by the construction of a berm. The undisturbed portion consists of buried prehistoric materials and the occasional bullet endemic to a military base. Due to heavy plowing and the considerable turbation caused by construction of the berms crossing this field, there is high surface exposure. A large amount of scattered debitage and burned rock is present over the disturbed portion of the site (see Mauldin and Broehm 2001:20-21). Figure 8-1 outlines the site as defined during the original survey, and shows the locations of previous shovel tests both in and around the site. Eleven shovel tests were placed within 41BR500 during the survey, with four of the 11 having artifacts. A single shovel test, located on the northwestern boundary of the site in the undisturbed area (see Figure 8-1), recovered seven flakes between 0 and $30 \mathrm{cmbs}$, along with several pieces of burned sandstone. In addition, this shovel test had high magnetic sediment susceptibility values. All of these data suggest that a buried feature or a stable surface with artifacts was present at that location. It was on the basis of this recovery that the site was recommended for testing (see Mauldin and Broehm 2001:21, 23).

The current testing project examined the small, undisturbed area along the extreme western edge of the site. Figure 8-2 presents a close-up of this area, and identifies the locations of 10 shovel tests as well as four test units placed on this site. The shovel tests were positioned along the length of the tested area (Figure 8-2). The 10 shovel tests were excavated to an average depth of roughly $41 \mathrm{cmbs}$, with the shallowest test (ST 1) excavated to $22 \mathrm{cmbs}$ and the deepest (ST 8) excavated to $60 \mathrm{cmbs}$. Shovel tests were terminated when underlying Pleistocene clay was encountered, when large sandstone blocks were encountered, or when $60 \mathrm{cmbs}$ was reached.
Three 1-x-1-m test units were placed to explore the possible feature area, and a fourth test unit (TU 4) was located to explore high lithic densities revealed in the shovel tests.

\section{Shovel Test and Test Unit Results}

Nine of the 10 shovel tests excavated were positive. One hundred and seventy-six pieces of debitage and two cores were recovered from the shovel testing. In addition, several small pieces of fire-cracked sandstone were noted. Most shovel tests recovered between one and 13 pieces of debitage. The exceptions were STs 5, 6, and 7 located near the center of the tested area. These three shovel tests accounted for 145 of the 176 pieces of debitage, with ST 5 having 78 debitage (44\%), ST 6 yielding 40 debitage (23\%), and ST 7 recovering 27 debitage (15\%).

Figure 8-3 presents a histogram of the number of debitage recovered in shovel tests by levels below surface. These figures have been corrected for the number of levels. For example, Level $4(30-40 \mathrm{cmbs})$ was reached in only six of the 10 shovel tests. Thirty-seven items were recovered from that level, so debitage density is approximately 6.17 items per excavated level for Level 4 across the site (37 items $/ 6$ excavated levels $=6.17$ ). Examination of the figure will suggest three different density modes, with small peaks in Levels 2, 4, and 6. However, note that none of the peaks are particularly distinct, with at least an average of 2.5 items present in all levels.

Test Units 1, 2 and 3 (Figure 8-2) were set up around ST 7 excavated during the original survey (see Figure 8-1). As noted previously, this shovel test had contacted a quantity of debitage and burned rock (Mauldin and Broehm 2001). The purpose of these three test units was to examine this area to discern the nature of this subsurface material. The three excavation units were placed adjacent to each other in a small block and are examined as a single entity. TU 4 was set next to ST 5 excavated on the current project (see Figure $8-2$ ). As noted above, this shovel test contained the highest number of debitage.

Test Units 1, 2 and 3 were excavated to a depth of approximately $30 \mathrm{cmbs}$. A detailed description of the sediments for this area can be found in Appendix D. Four hundred and 


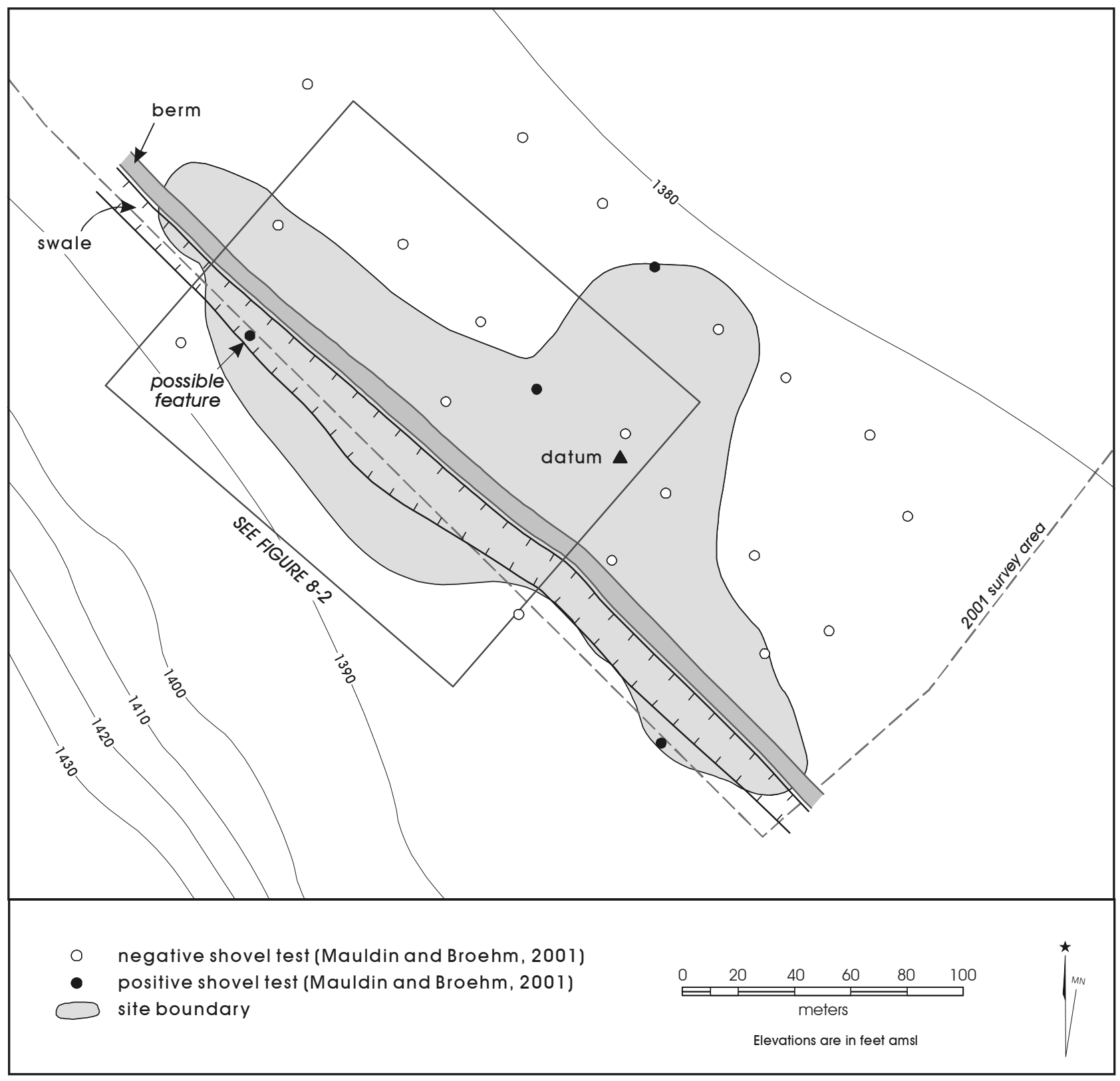

Figure 8-1. Site boundary and previous work at $41 B R 500$.

fifty-one items, including 441 pieces of unmodified lithic debitage, a dart point, seven bifaces, a chopper, and a scraper were recovered from this excavation area. TU 1 had 107 items, TU 2 had 229 items, and TU 3 had 115 items recovered. Level $1(0-10 \mathrm{cmbs})$ recovered the majority of the chipped stone, with 222 items, Level $2(10-20 \mathrm{cmbs})$ had 183 items, and Level 3 (20-30 cmbs) had 46 items. Burned sandstone, as well as unburned sandstone, was present in each unit in all levels excavated. However, no clear pattern in the distribution of the burned rock could be ascertained. Most of the burned rocks, including several of the larger burned rocks, were concentrated in the upper 20 $\mathrm{cm}$ of excavation. Figure 8-4 presents a composite plan view of the three units. The plan view, compiled from level forms, represents roughly 0 to $30 \mathrm{~cm}$. The plan view includes the approximate boundaries of concentrations of smaller burned rock fragments. Note that the burned rock scatter extends beyond the sidewalls of each test unit (Figure 8-4). No burned soil, darkened sediment, or associated pit was observed. Small flecks of charcoal were observed, 


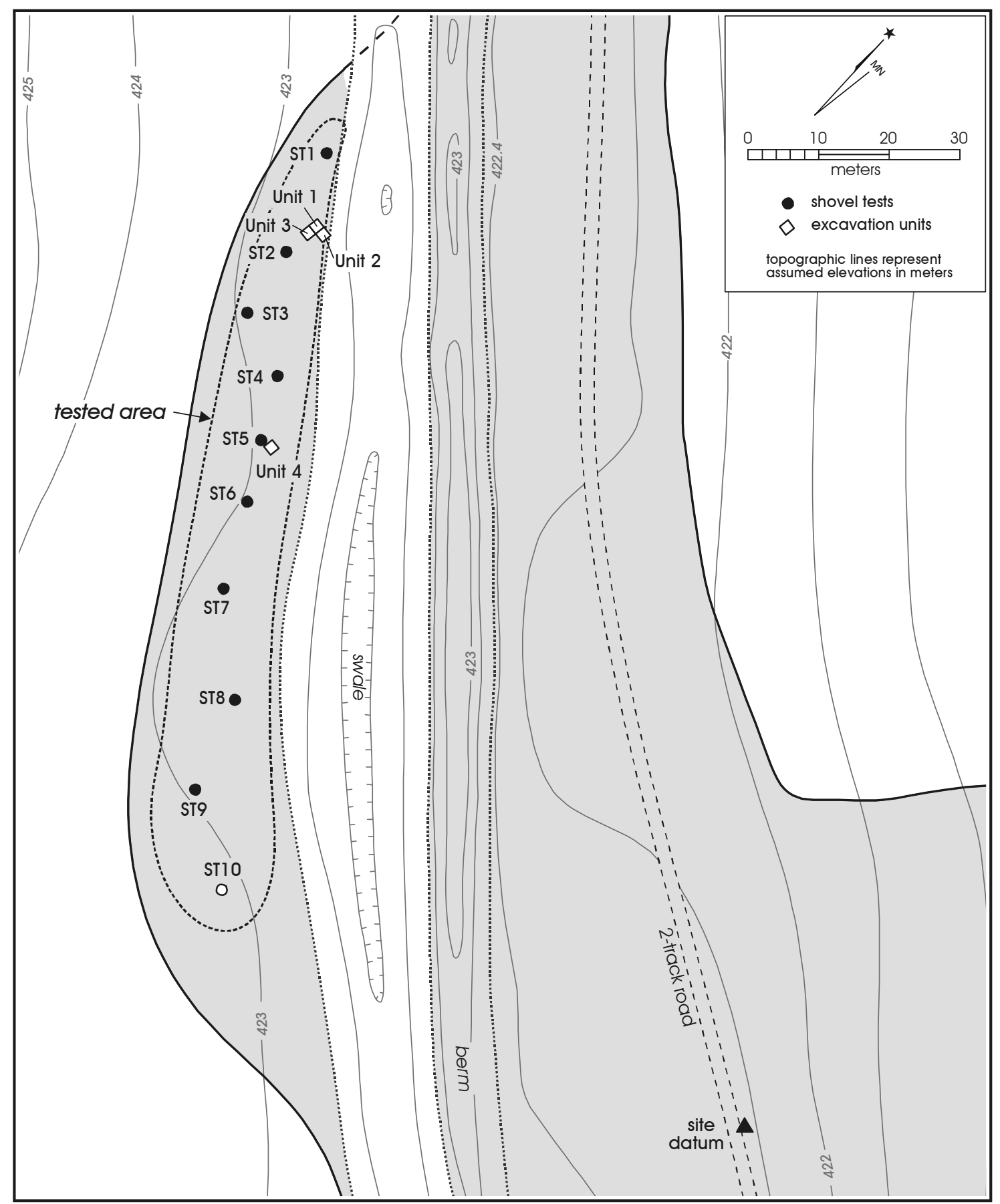

Figure 8-2. Locations of shovel tests and test units for current work at 41BR500.

though not collected, at 20-25 cmbs in TU 2. In addition, charcoal was observed and collected in TU 3 at $19 \mathrm{cmbs}$. A small concentration of burned clay was also present in TU 1 at 10 cmbs.
Nineteen magnetic sediment susceptibility samples were collected and processed from these three units. Five samples were collected from TU 1, seven samples from TU 2, and 


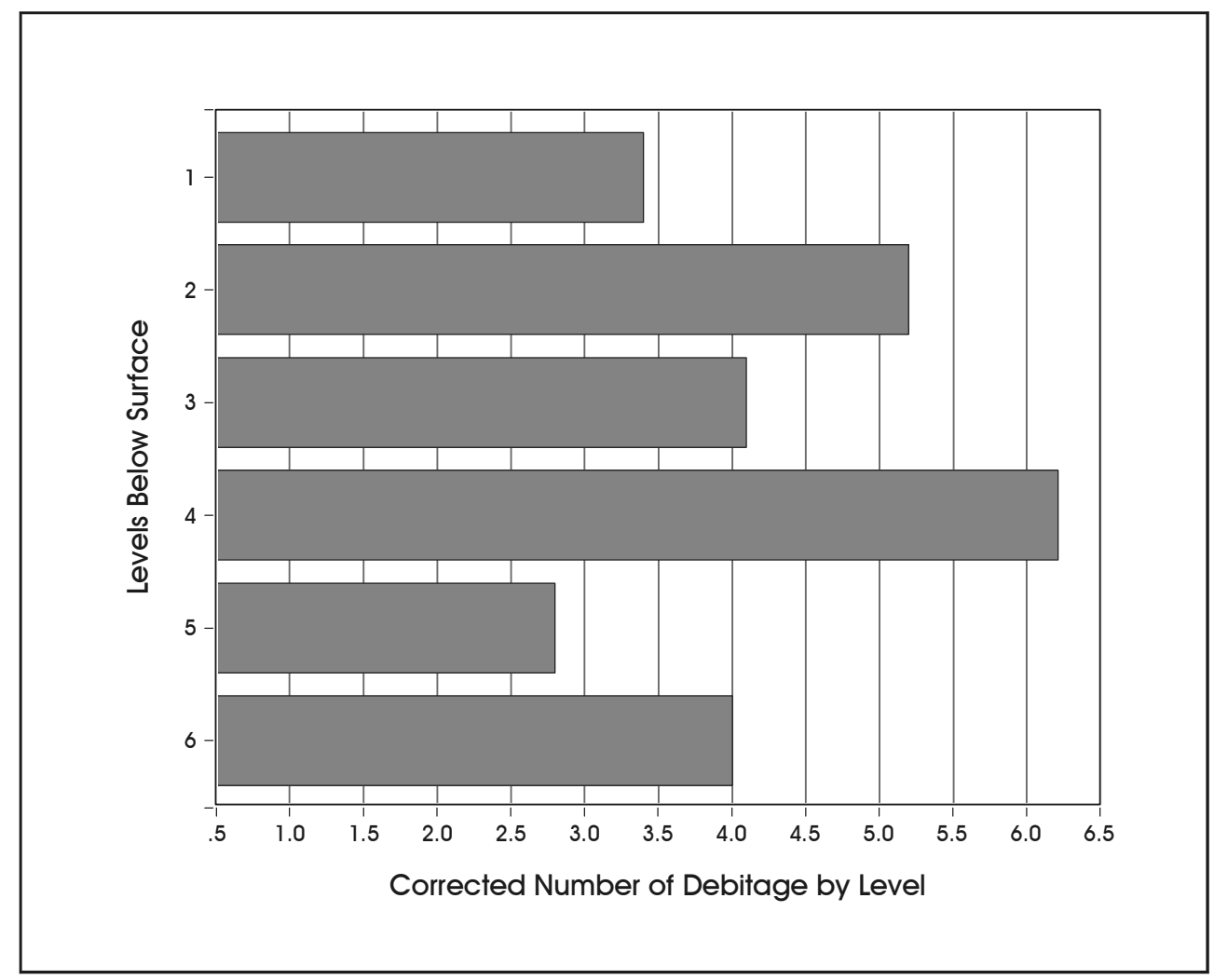

Figure 8-3. Distribution of debitage from shovel tests at 41BR500.

seven samples from TU 3. As discussed in Chapter 6, the strength of the MS signal should be responding, in part, to the concentration of charcoal, ash, and organics in a sample. Figure 8-5 presents the magnetic sediment susceptibility values for the three units. Note that two of the units (TUs 2 and 3) have roughly similar patterns, with a single, strong peak at about $25 \mathrm{cmbs}$. This is consistent with a surface at that point. Unfortunately, this peak does not correspond to the patterning in the artifacts noted previously. Ninety percent of the chipped stone material recovered from these test units was recovered from the upper $20 \mathrm{~cm}$ of the deposits.

The lack of any accompanying burned earth or pit outline, the lack of patterning in the distribution of burned rock, and the low frequency of charcoal suggests that the burned rock in these three units probably does not represent an intact thermal feature. The general scatter of burned rock and its mixing with unburned rock is consistent with the burned and unburned rock scattering that is on the surface at a low density over much of the site area. The burned rock in the three units probably originated at some location within site $41 \mathrm{BR} 500$, or is colluvium from upslope. In either case, the deposit is probably secondary in nature. This suggestion is supported by the evaluation of sediments in Appendix D. Greaves notes that sediment movement, probably due to slopewash and erosion, might characterize this area. While there is certainly some support for a buried surface or a concentration of organic-rich material in the magnetic susceptibility curves in TUs 2 and 3, the pattern in TU 1 is not consistent with that suggestion.

Test Unit 4 was located approximately $30 \mathrm{~m}$ to the southsoutheast of TUs 1, 2, and 3, near ST 5 (Figure 8-2). The unit was excavated to an approximate depth of $65 \mathrm{cmbs}$, in seven levels, with the initial level being only $5 \mathrm{~cm}$ thick. A detailed description of the sediments in this unit can be found in Appendix D. Excavation produced over 400 artifacts, including 399 debitage, nine bifaces, four dart points, and a chopper. Fire-cracked rock was present in the upper $35 \mathrm{~cm}$ of the deposit, but burned rock was not noted below Level 4 . In addition, 0.6 grams of mussel shell was present in Level 4.

Figure 8-6 presents the distribution of chipped stone material by $10-\mathrm{cm}$ levels for TU 4 . The counts for Level 1, which was only $5 \mathrm{~cm}$ thick, have been doubled for this figure. Note that the upper two levels contained the vast majority of the 


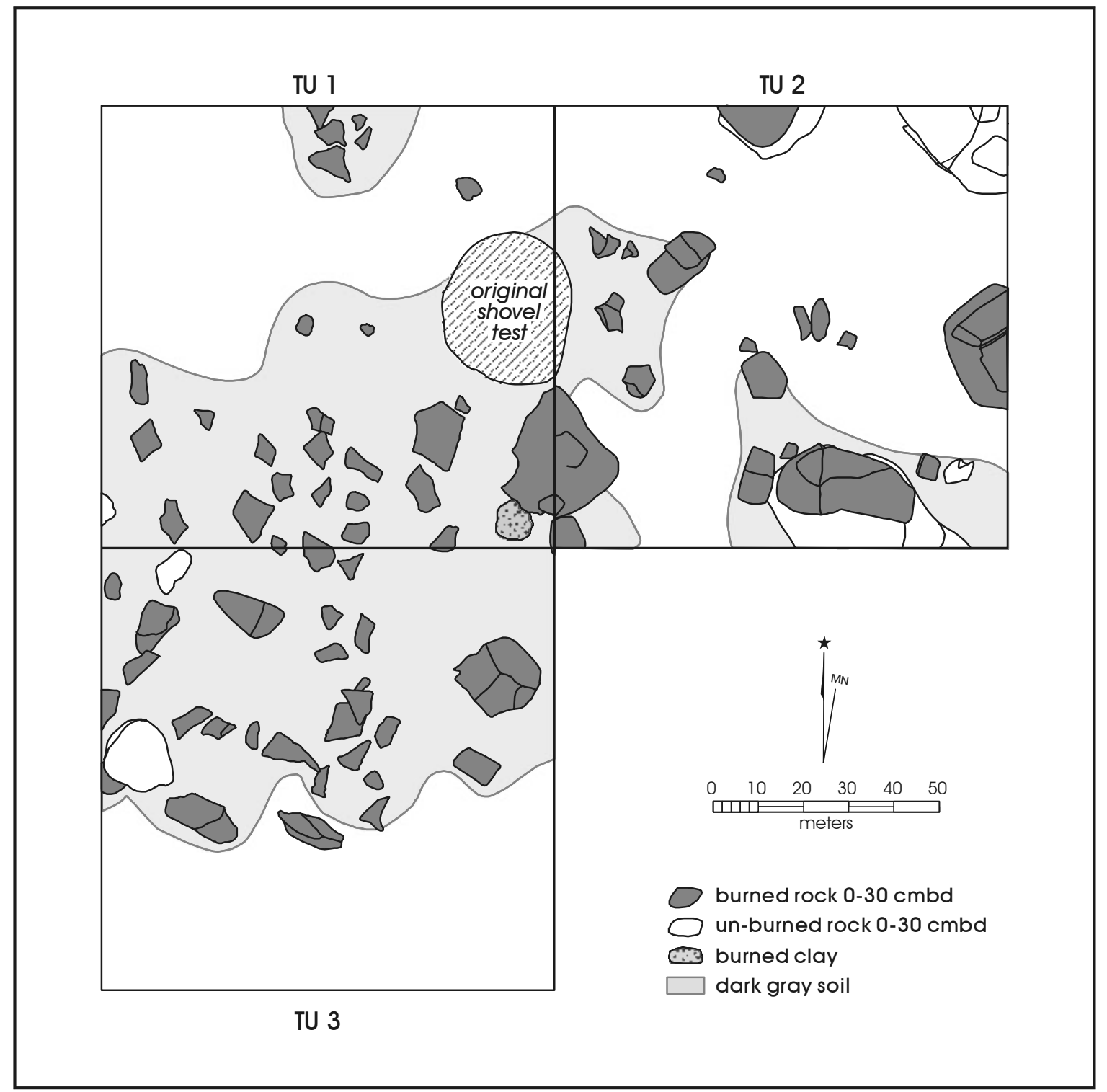

Figure 8-4. Plan view of Test Units 1, 2, and 3 at 41 BR500.

material, with a rapid and consistent drop-off in density with depth. This pattern is consistent with a limited area of occupation, probably between 0 and $20 \mathrm{cmbs}$ in this case, which has subsequently undergone some movement of artifacts. This suggestion is supported, to some degree, by the size of the artifacts through this deposit. Given the silty clay sediments with numerous vertical cracks, and the potential for expansion and contraction in these soils as a result of wetting and drying, we would anticipate that while a variety of different sized artifacts may move in complex ways (see Waters 1992:299-300), over the long term, smaller artifacts may differentially move downward as a function of displacement into vertical cracks. Using the maximum length of chipped stone debitage as a measure of artifact size, the average debitage size for the upper two levels is $15.85 \mathrm{~mm}(\mathrm{n}=194)$. For Levels 3 through 5, the average size drops to $14.72 \mathrm{~mm}(\mathrm{n}=182)$. Finally, the artifacts in Levels 6 and 7 average only $12.72 \mathrm{~mm}$ in maximum length $(\mathrm{n}=23)$.

Additional support for the presence of only a single buried surface is provided in Figure 8-7, the results of the magnetic sediment susceptibility analysis (see also Appendix C). A single peak, at roughly $20 \mathrm{cmbs}$, is suggested by these values. While a secondary peak may also be present at $45 \mathrm{cmbs}$, 


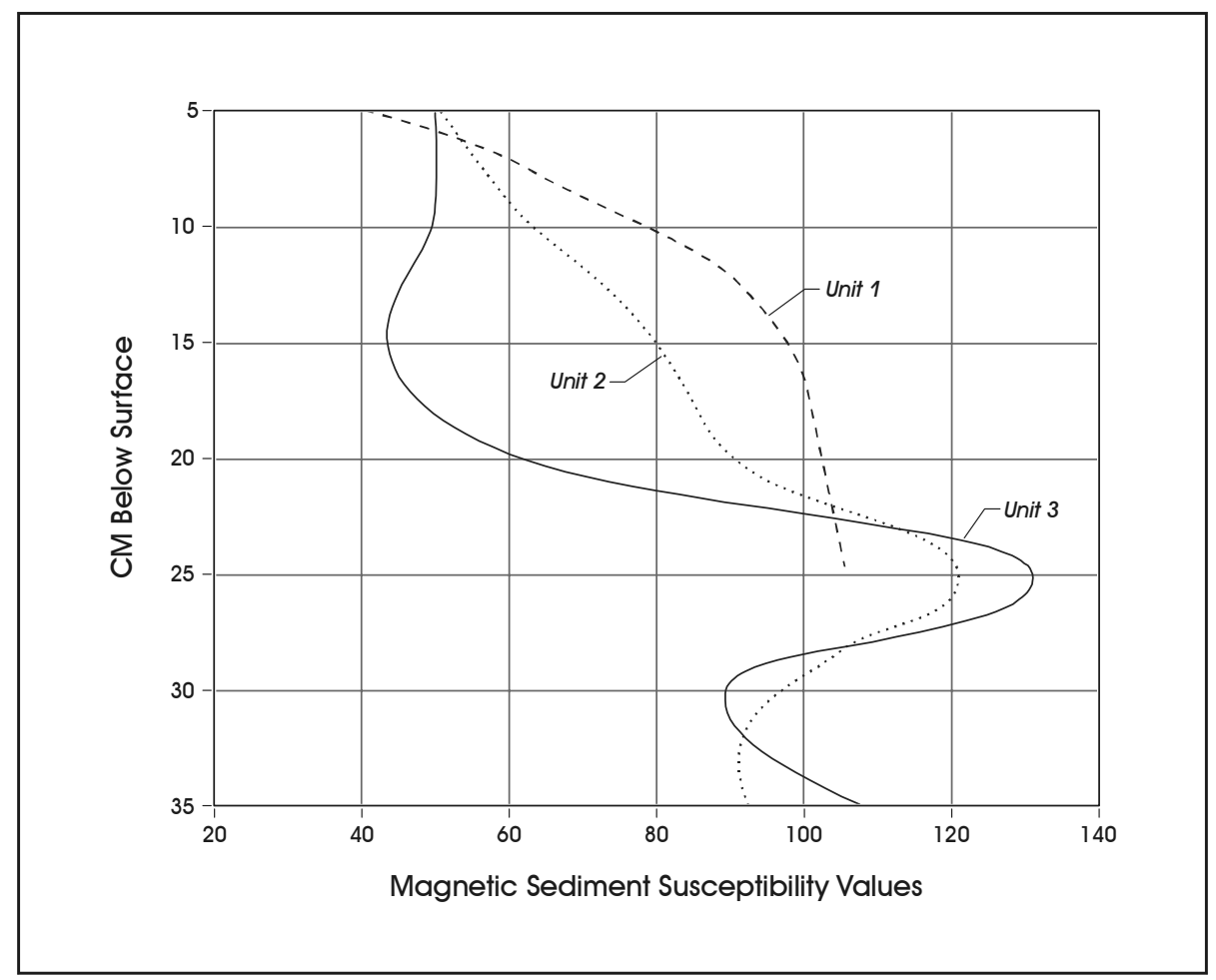

Figure 8-5. Magnetic sediment susceptibility values for Test Units 1, 2, and 3 at 41 BR500.

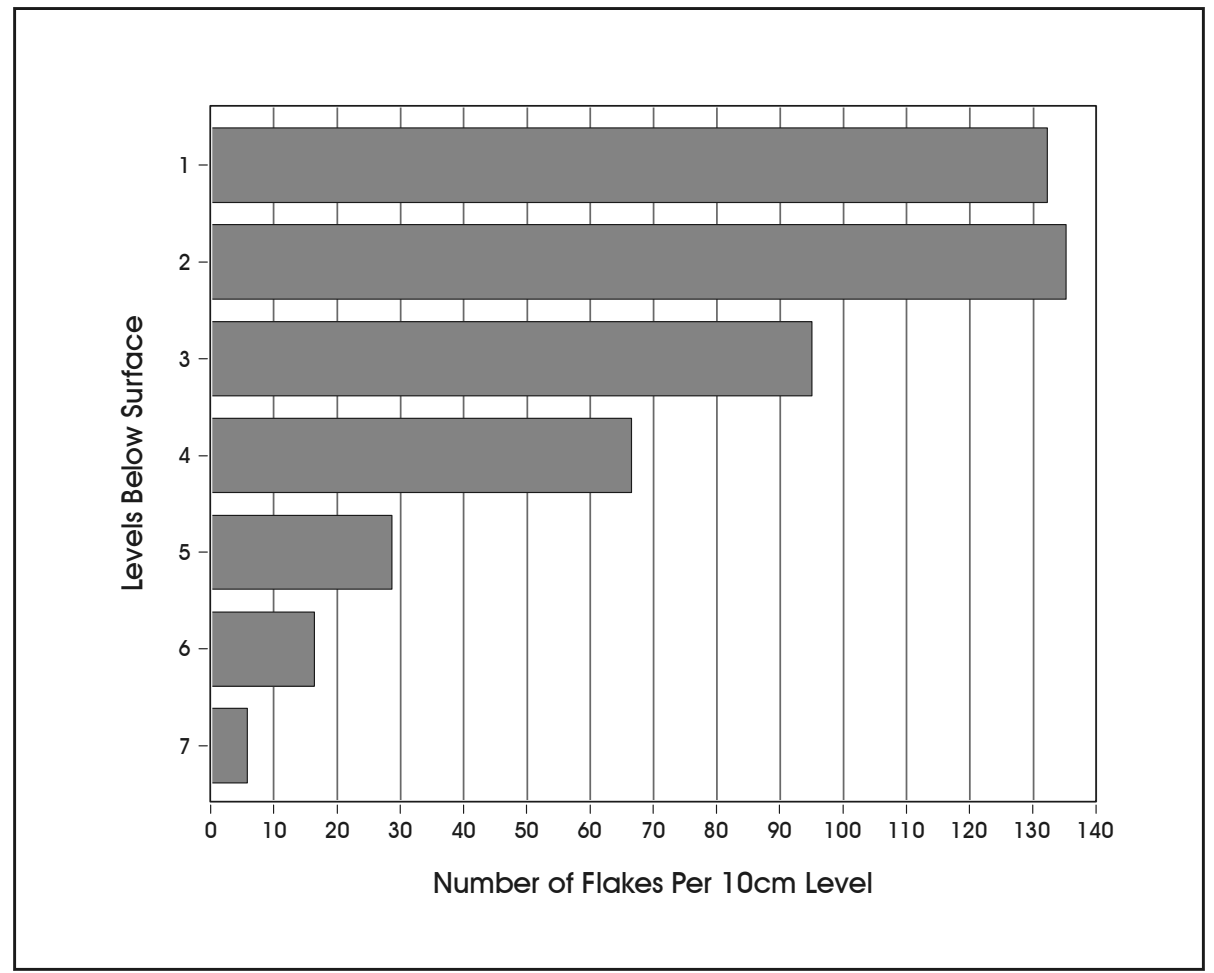

Figure 8-6. Distribution of chipped stone from Test Unit 4 at 41 BR500. 
the overall trend in the curve seems to mirror the artifact distributions shown in Figure 8-6.

A single feature was identified in TU 4. Designated Feature 1 , the charcoal stain was first noted at roughly $18 \mathrm{cmbs}$, a depth very close to the $20 \mathrm{cmbs}$ depth of a possible buried surface reflected in the sediment susceptibility graph (Figure 8-6). The feature, however, was not clearly defined until 29 cmbs. Figure 8-8 presents a plan view of this feature at that depth. The feature, located along the northern edge of the excavation unit, contained several pieces of chipped stone, a small amount of burned sandstone, and darkened sediment with scattered charcoal. The feature was roughly basinshaped and about $15 \mathrm{~cm}$ in depth. Two flotation samples from the feature were submitted to Philip Dering of Texas A\&M University for analysis. Neither sample produced any identifiable carbonized remains (see Appendix B).

One charcoal sample from this feature, collected near the feature base at $38 \mathrm{cmbs}$, was submitted to Beta Analytic for radiocarbon dating. The resulting corrected AMS radiocarbon date was $1220 \pm 40 \mathrm{BP}$ (see Appendix A). Using the OxCal Calibration program (Ramsey 2000), this date calibrates to A.D. 720-890 at 1-sigma, with the highest probability (61\%) being between A.D. 770 and A.D. 890. As noted previously, four dart points were collected from this excavation area. While these are discussed in detail in the subsequent section, note that only two of these points could be typed. The basal fragment of a Middle Archaic Nolan point (circa 4000 to 2500 B.C.) was found on the surface of the unit. This point is clearly out of context. In addition, a probable Darl point was found at $14 \mathrm{cmbs}$. This Late Archaic form has a tentative date of roughly A.D. 200 (Turner and Hester 1999). At roughly the same level as the Darl point (15 cmbs) was an untyped, Late Archaic form. Finally, an untypable point was recovered at $26 \mathrm{cmbs}$.

\section{The Chipped Stone Assemblage}

As touched on previously during the shovel test and test unit descriptions, a variety of chipped stone was recovered from 41BR500 during this testing phase. Over 1,025 chipped and ground stone items were collected from this site, including 1,013 pieces of debitage, two cores, five projectile points and 18 other formal chipped stone tools, and one mano/hammerstone.

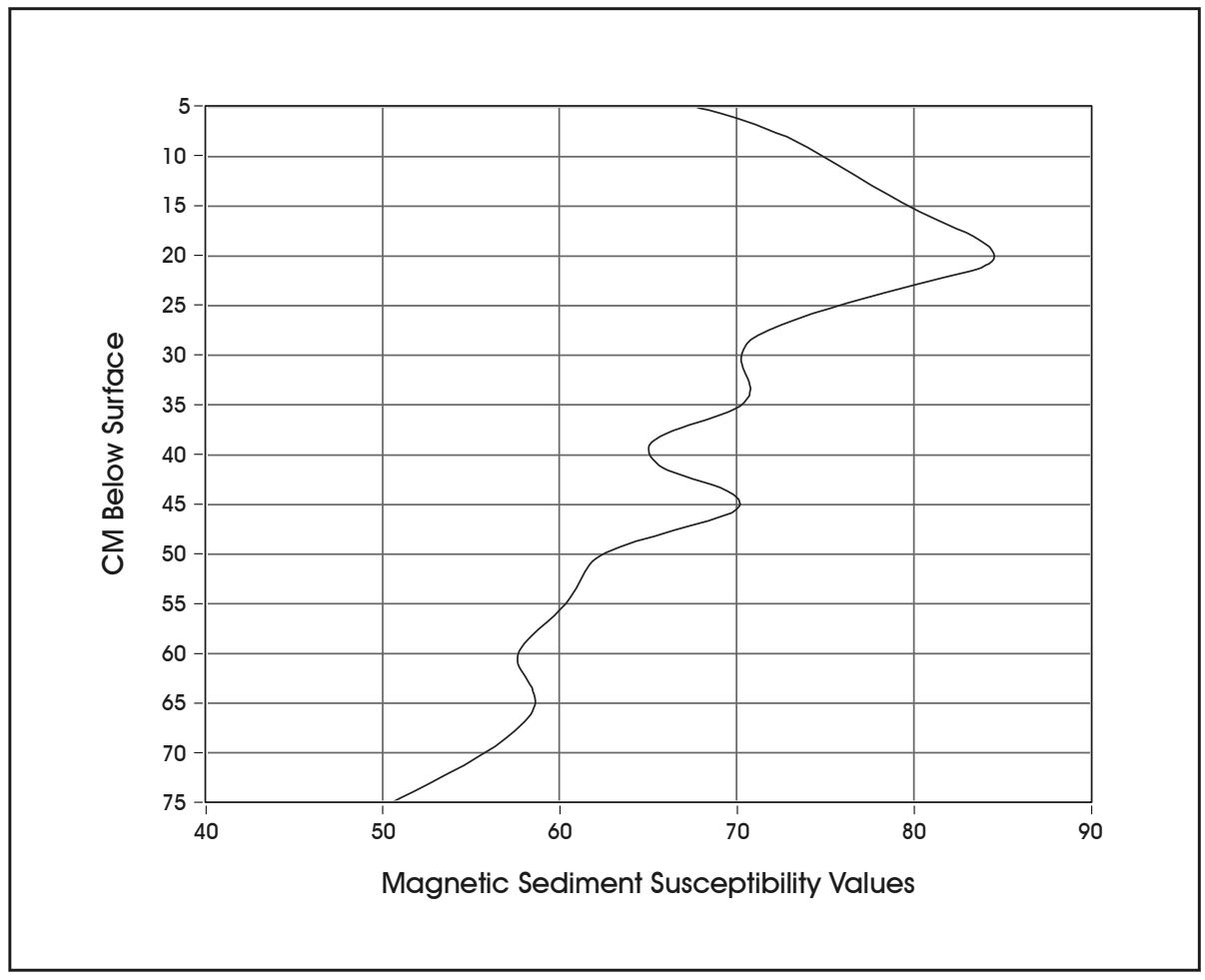

Figure 8-7. Magnetic sediment susceptibility values from Test Unit 4 at 41 BR500. 


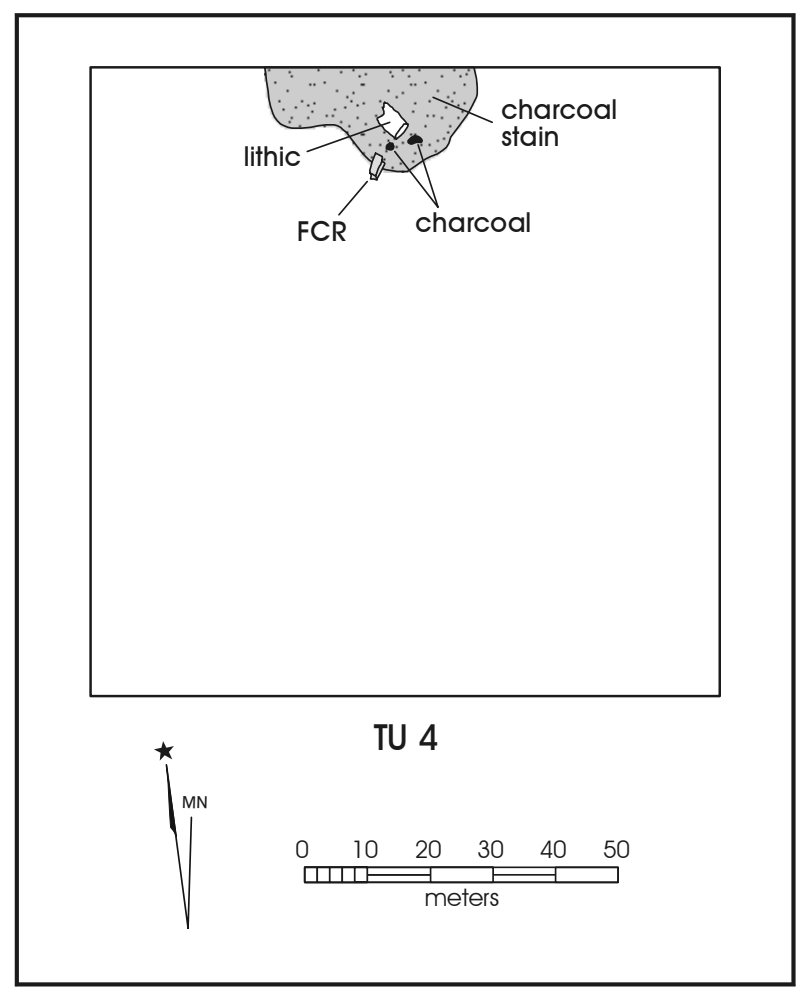

Figure 8-8. Plan view of Feature 1 at $29 \mathrm{cmbs}$ in Test Unit 4 at $41 B R 500$.

The debitage from the site seems to suggest a focus on the reduction of partially decorticated blanks or late reduction activities. Cortex was not present on $79 \%(\mathrm{n}=801)$ of the debitage, with only $4.2 \%(n=43)$ having more than $50 \%$ cortex present. Table $8-1$ presents the cortex patterns at this site and contrasts them to the combined 622 pieces of debitage with cortex percentages from the remaining three sites. Standardized adjusted residual values for each cell are included below the raw counts. Recall that absolute values exceeding 1.96 suggest a significant difference in this cell at a probability exceeding .05 (Everitt 1977; Haberman 1973). It is clear from the standardized adjusted residual values that the patterns of cortex at 41BR500 are significantly different from the combined sample from the remaining sites in all three categories. 41BR500 has significantly more tertiary ( $0 \%$ cortex) flakes, and significantly fewer flakes with cortex when compared to the remaining site assemblages tested on this project.

The thickness/length ratio of complete flakes supports the assessment of an assemblage derived from late reduction, or the reduction of partially cortical cores or blanks. The 181 complete flakes have a mean thickness/length ratio of .187. Values greater than .26 are probably suggestive of a focus on early stage reduction.

The analysis of flake types is consistent with the results from the cortex patterns and thickness/length ratios. At this site, indeterminate flakes make up $61.5 \%(\mathrm{n}=623)$ of the debitage. Table 8-2 contrasts the flake type patterns for 41BR500 with the remaining sites, with both the indeterminate and "other" flake types eliminated. Examination of the table will show that, from the perspective of 41BR500, three cells - angular debris, biface thinning flakes, and platform preparation flakes-have significant adjusted residual values, with both angular debris and bifacial thinning flakes underrepresented, and platform preparation flakes overrepresented. Note also that core preparation flakes are under-represented at this site, but the differences are not statistically significant for this cell. The under-representation of angular debris in this assemblage may be indicative of a low frequency of core reduction. When contrasted with bifacial reduction, this form of reduction commonly results in higher percentages of angular debris. This pattern is also consistent with the trend seen in the core preparation cell (see Table 8-2). While biface thinning is clearly not a major activity reflected in the assemblage, and while biface manufacturing flakes are not over-represented, some level of biface manufacturing is consistent with the higher totals for platform preparation flakes. Note also that only two cores were recovered during our work at the site. In contrast, 16

Table 8-1. Counts and Adjusted Residual Values for Cortex Patterns, 41BR500 and Remaining Sites

\begin{tabular}{|c|c|c|c|c|c|c|}
\hline & & \multicolumn{3}{|c|}{ Cortex Percentage } & \multirow{2}{*}{$\begin{array}{c}\text { Total } \\
\text { Counts } \\
\end{array}$} & \multirow[b]{2}{*}{ Percentage } \\
\hline & & $0 \%$ & $1-50 \%$ & $51-100 \%$ & & \\
\hline $\begin{array}{l}\text { All Other } \\
\text { Sites }\end{array}$ & $\begin{array}{l}\text { Raw Counts } \\
\text { Adjusted Residual }\end{array}$ & $\begin{array}{r}440 \\
-3.82 \\
\end{array}$ & $\begin{array}{l}135 \\
2.53\end{array}$ & $\begin{array}{c}47 \\
2.85 \\
\end{array}$ & 622 & $38.0 \%$ \\
\hline \multirow[t]{3}{*}{ 41BR500 } & $\begin{array}{l}\text { Raw Counts } \\
\text { Adjusted Residual }\end{array}$ & $\begin{array}{r}801 \\
3.82 \\
\end{array}$ & $\begin{array}{r}169 \\
-2.53 \\
\end{array}$ & $\begin{array}{r}43 \\
-2.85 \\
\end{array}$ & 1013 & $61.9 \%$ \\
\hline & Total Counts & 1241 & 304 & 90 & 1635 & \\
\hline & Percentage & $75.9 \%$ & $18.6 \%$ & $5.5 \%$ & & \\
\hline
\end{tabular}


Table 8-2. Counts and Adjusted Residual Values for Flake Types, 41BR500 and Remaining Sites

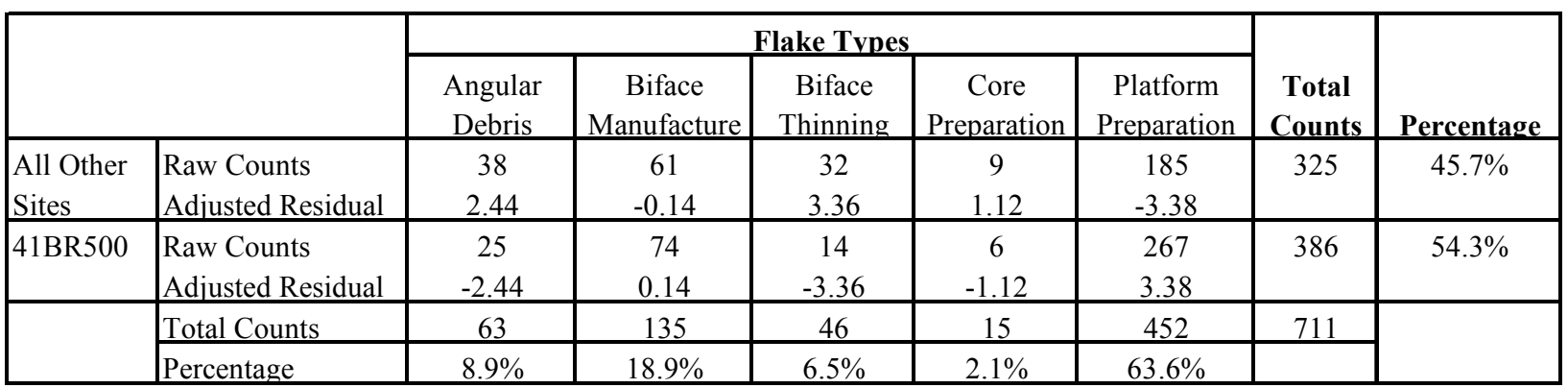

bifaces, five projectile points, and two other formal chipped stone tools were recovered. The dominance of the bifacially worked material relative to the low number of cores is clearly consistent with these debitage patterns.

\section{Tools}

Five projectile points, 16 bifaces, a chopper, a scraper, and a mano/hammerstone were recovered by CAR during the testing of this site.

Figure 8-9 presents the five projectile points recovered from the site. Figure 8-9a is the proximal end of a Middle Archaic Nolan dart point recovered from the surface near TU 4. Figure $8-9 \mathrm{~b}$ is a medial fragment of an untyped dart point. While most of the blade is present, with parallel flaking along the margins, the tip is broken, as is the bottom half of the hafting element. The shoulders leading into the hafting element are strong and the area below the shoulders could represent either notching or transition into a stem. Figure $8-9 \mathrm{c}$ is typed as a Darl, though it has some resemblance to the Darl/Godley dart points found in collections from Stephens, Throckmorton, and Young counties to the north of the project area (Ensor et al. 1992). Figure 8-9d is a straight-stemmed dart point with strongly angled shoulders, a triangular blade and slight excavation damage. While this point is not typed, it clearly is consistent with a Late Archaic form. The final point (Figure 8-9e) is an unstemmed, or perhaps weakly shouldered, parallel-sided point with a convex base and an impact fracture on the tip.

Figure 8-10 presents scans and a drawing of three of the other tools collected at 41BR500. The chopper is a roughly symmetrical, early-stage biface or core fragment showing battering and step fractures along its thick margins (Figure 8-10a). A single hammerstone, also used as a mano, is depicted in Figure 8-10b. The specimen has battering along one end, and one side of the item has been ground. The item was collected from the surface of the site, roughly $25 \mathrm{~m}$ from the TUs 1-3 testing area. Figure 8-10c presents several views of the single scraper, collected from TU 1 . The scraper is made on a flake. There are two working edges present that occur on opposing, alternate bevels. Figure 8-10c shows the alternately beveled scraper in detail, indicating (a) major working edges, (b) a minor utilized edge, and (c) a break that removed a portion of one major working edge.

Figure 8-11 presents the 16 bifacial tools. Generally, these represent mid- to late-stage reductions. Several specimens have manufacture breaks (e.g., Figure 8-11f, h, and o) and two exhibit severe thermal damage (Figure 8-11g and j). One biface (Figure 8-11p) has cortex covering $51-99 \%$ of one face and is symmetrical. It appears to be in the early stages of reduction and is made from a primary flake.

\section{Summary}

Originally described by Mauldin and Broehm (2001), site 41BR500 consists of a scatter of chipped stone debitage, several bifaces, unifaces, ground stone, projectile points, and scattered burned rock. Much of the site has been disturbed, but a small section appeared to be intact and potentially contained a buried feature (Mauldin and Broehm 2001:20-21). As such, the site was recommended for testing. The testing effort focused on the undisturbed portion of 41BR500. Testing involved both shovel testing and the excavation of test units. The most recent work at 41BR500 yielded over 1,000 pieces of unmodified lithic debitage, 16 bifaces, five dart points, a chopper, a scraper, two cores, and a hammerstone/mano. Consideration of a number of debitage characteristics suggests that much of this material reflects late-stage bifacial reduction, or the reduction of partially cortical blanks. 


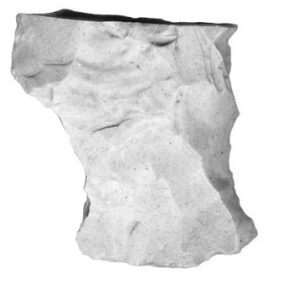

a

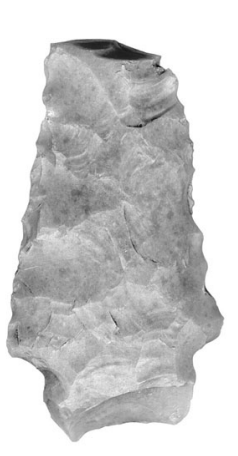

b

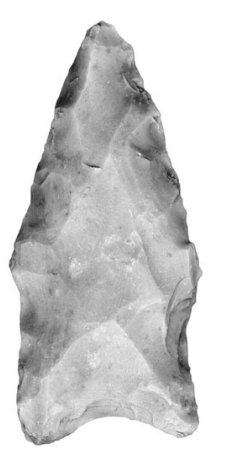

C

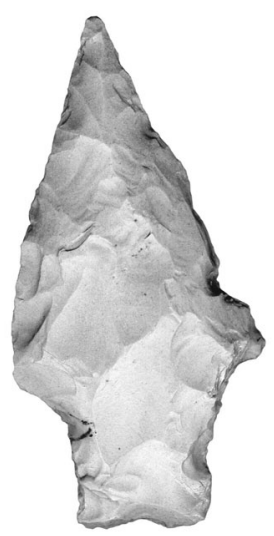

d

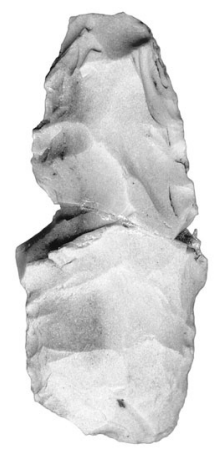

e

\begin{tabular}{|c|c|c|c|c|c|}
\hline 0 & 1 & 2 & 3 & 4 & 5 \\
\hline 1 & 1 & $A$ & & I & \\
\hline
\end{tabular}

Figure 8-9. Projectile points recovered from 41BR500. a) Middle Archaic Nolan; b) untyped; c) Darl (possible Darl/Godley); d) untyped Late Archaic form; e) untyped.

Results of the shovel testing demonstrated that subsurface deposits are present down to roughly $70 \mathrm{cmbs}$ at several places on this portion of the site. However, no clearly distinct subsurface concentrations were present, though three minor peaks in artifact density were observed. No charcoal, bone, or evidence of features was identified during the shovel testing.

Test Units 1,2, and 3 explored the potential feature identified during the previous survey. While scattered burned rock and chipped stone debris were recovered at this location, no clearly distinct feature could be identified. While sediment susceptibility values seem to peak in two of the three units at 20 to $25 \mathrm{cmbs}$, this peak does not correspond to peaks in artifacts. It is probable, then, that the burned rock is part of a more general, diffuse scatter, and may represent a secondary deposit rather than an intact feature.

One feature (Feature 1) was identified in TU 4. The feature was a small charcoal stain with minor amounts of burned rock. A radiocarbon date was obtained and suggests a Late Prehistoric (circa A.D. 720-890) use date. Several diagnostic artifacts, including a Middle Archaic Nolan point from the surface and two Late Archaic forms (Darl and an untyped
Late Archaic point) from excavation, were recovered in TU 4. All of these points were above Feature 1. These vertical relationships suggest that either the radiocarbon date does not provide an accurate measure of the period of feature use, or much of the material above Feature 1 may be out of context. Some additional evidence for displacement of artifacts in this unit can be found in the distribution of debitage. A consideration of the vertical distribution of debitage suggests a consistent decrease in both the number of items and the average size of items with decreasing depth. This debitage pattern is supported by patterns in magnetic susceptibility values from TU 4. Coupled with the observation that the diagnostic points do not pattern vertically and do not pattern with the radiocarbon date, these data suggest that material within this test unit, like the TU 1-3 area, is probably not in good context.

No ethnobotanical material was recovered from the two flotation samples submitted from Feature 1. No bone was collected from any of the test units at this site, though mussel shell was noted in one excavation area at a low density. It was not clear if the shell was cultural. 


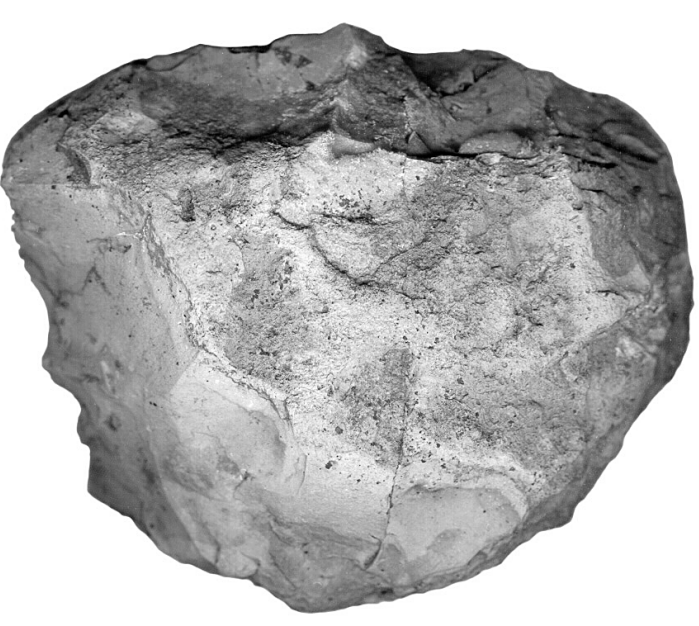

a

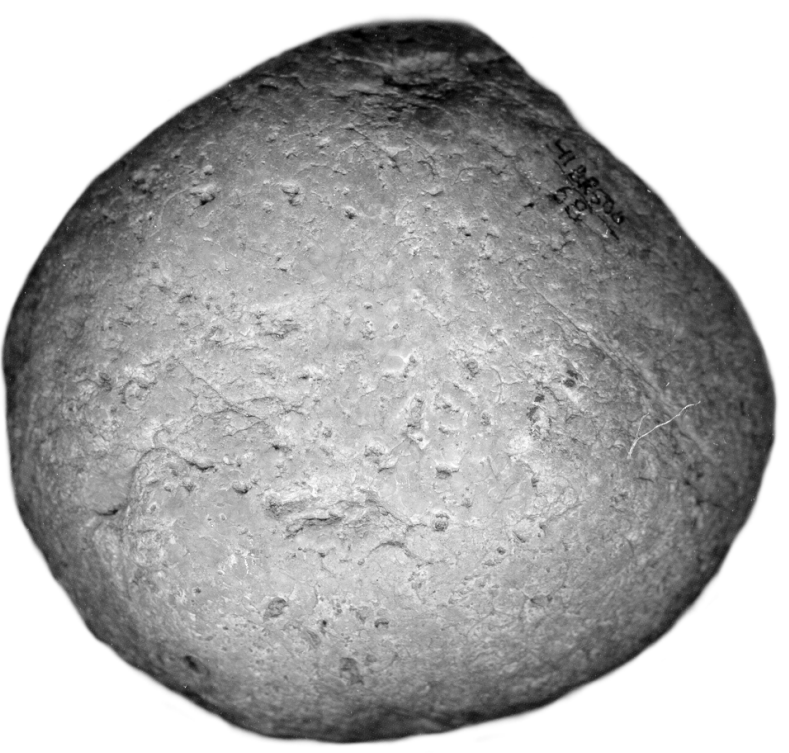

b
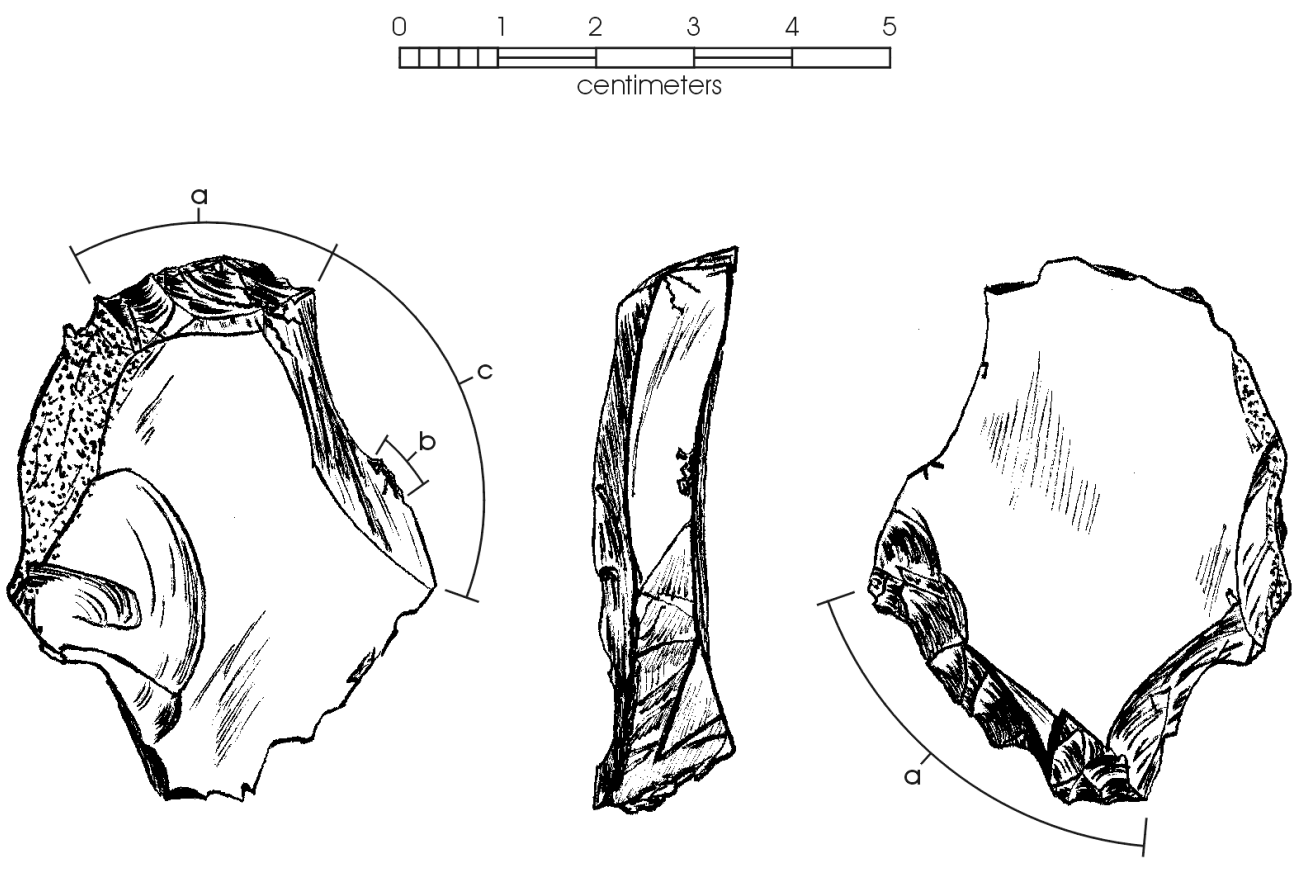

C

Figure 8-10. Selected tools recovered from 41BR500. a) chopper; b) hammerstone/mano; c) scraper. 


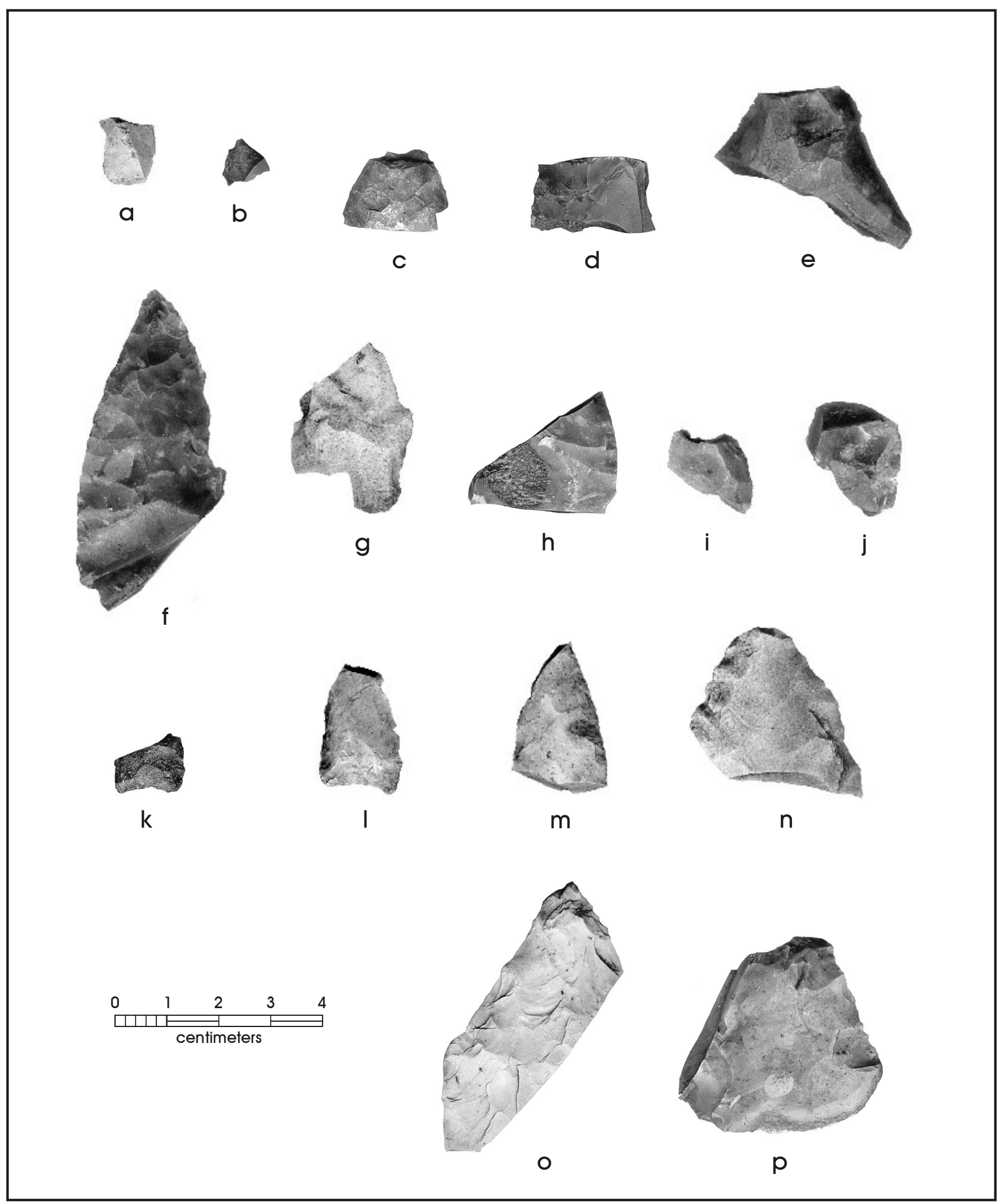

Figure 8-11. Bifacial tools recovered from 41 BR500. 


\title{
Chapter 9: $\quad$ Testing Results at Site 41BR522
}

\author{
Jason D. Weston and Raymond P. Mauldin
}

In this chapter we discuss the results of the testing performed at site 41BR522. Findings concerning all shovel testing and test excavations are outlined. In addition, details of all artifacts, radiocarbon analysis, and ethnobotanical analysis are provided.

\section{Site $41 \mathrm{BR} 522$}

Site 41BR522 was originally recorded by Greaves (2002: 17-21). The site, which is situated on the lower slope of the east-west trending ridge that dominates this portion of Camp Bowie (see Chapter 2 and Appendix D), contains a single burned rock midden. The midden is a low, circular sandstone accumulation of burned rock, roughly $14 \mathrm{~m}$ by $15 \mathrm{~m}$ in size. The midden sits on a slope and appears to be between $50 \mathrm{~cm}$ and $1 \mathrm{~m}$ in thickness. A central depression is clearly visible, forming a basin roughly $10 \mathrm{~m}$ wide and approximately $10 \mathrm{~cm}$ lower than the talus ring. There is a low-density surface scatter of lithics that surrounds the midden area. In addition, there is a relatively recent fence line just to the south of 41BR522. Greaves (2002:19-20) placed seven shovel tests in this area, five of which contained either fire-cracked rock or chipped stone (Figure 9-1). In addition, shovel test STN 1 (Figure 9-1) contained charcoal and mussel shell between 20 and $40 \mathrm{cmbs}$. One shovel test (STE 1 on Figure 9-1), excavated in the midden, produced a high number of pieces of fire-cracked sandstone. That shovel test was terminated at $20 \mathrm{cmbs}$ when several large, burned sandstone rocks were encountered that prevented further excavation. Based on the observation that the midden appeared to be undisturbed, the high frequency of positive shovel tests, and the presence of charcoal, Greaves (2002:21) recommended that additional testing be conducted at this location to determine the eligibility of the site for SAL and NRHP status.

The additional testing at this site involved the excavation of 21 shovel tests placed around the midden feature, the excavation of five $1-x-1-\mathrm{m}$ units within the feature, and the excavation of a single 1-x-1-m unit at the southern end of the site (Figure 9-2). As with site 41BR392, most of the shovel tests were excavated on a roughly $5-\mathrm{x}-5-\mathrm{m}$ grid focused to the east and south of the feature. Bedrock was exposed on the western side of the midden, and was also present just to the north of the feature. Four shovel tests
(STs 1, 19, 20, and 21) were placed slightly farther away from the midden (Figure 9-2). The 21 shovel tests were excavated to an average depth of just over $50 \mathrm{cmbs}$, with all shovel tests excavated into Level $3(20-30 \mathrm{cmbs})$ and 19 of the 21 shovel tests excavated into Level 5 (40-50 cmbs). The maximum shovel test depth was $60 \mathrm{cmbs}$, obtained in four shovel tests (STs 2, 12, 19, and 20). One hundred and six separate levels were recorded in these 21 shovel tests.

In addition to the shovel tests, CAR excavated six test units at this site. Five contiguous test units (TU 1-TU 5) were excavated from the center of the feature area through much of the ring (see Figure 9-2). Initially, two adjacent units (TUs 1 and 2) were placed in the center of the feature and a third unit (TU 3) was placed on the edge of the ring. This was essentially the same strategy used at 41BR392, however, our initial test units showed that this midden was shallow, with excellent preservation of the internal structure of the deposits. In addition, good preservation of charred plant material was present in the initial tests. Therefore, we decided to expand our investigations with the excavation of TUs 4 and 5, thereby connecting the central feature and ring area (see Figure 9-2). A sixth unit (TU 6) was placed off-midden, along the southern boundary of the site (Figure 9-2) in order to document the fall-off of material suggested by the shovel test results.

Finally, note that no historic or modern non-military materials were recovered from excavations in spite of the presence of a corral area. The ranching operation appears to have had no significant impact on the site, and in fact the fence may have served to protect 41BR522 from more recent disturbance.

\section{Shovel Test Results}

Figure 9-2 shows the location of the 21 shovel tests excavated. Note that none of the 21 tests were in the midden, though three (STs 10,11, and 15) were on the feature edge. Eighteen of the 21 shovel tests at 41BR522 were positive, containing either chipped stone $(n=12)$, burned rock $(n=10)$, or mussel shell $(n=6)$. Not surprisingly, the shovel tests suggest some focus on the midden, though the pattern is not as clear as was the case for 41BR392. Of the three negative shovel tests (STs 1, 5, and 19), two (STs 1 and 19) were 


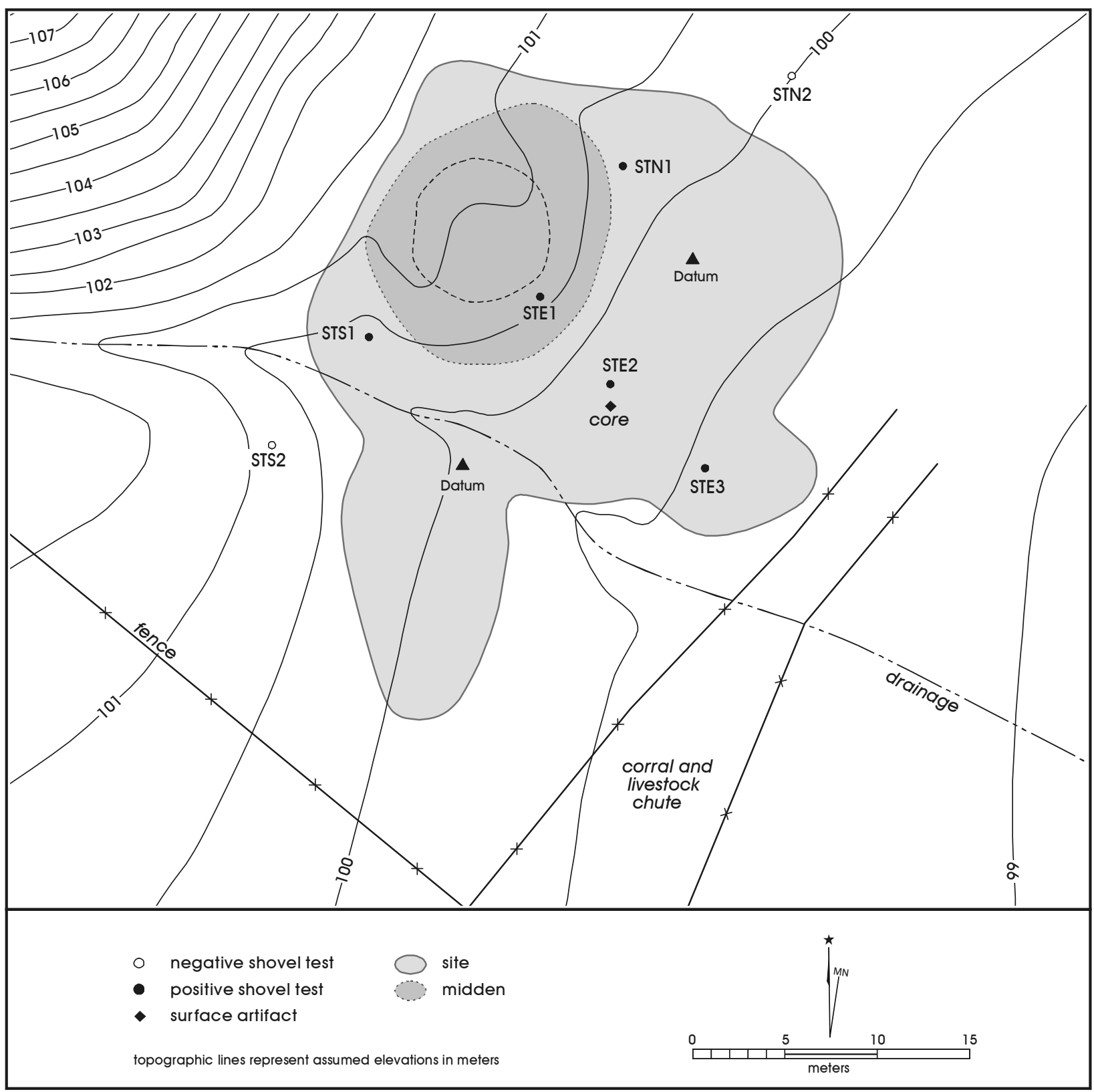

Figure 9-1. Site boundary and previous work at 41BR522.

located more than $12 \mathrm{~m}$ away from the midden, though ST 5 was only $5 \mathrm{~m}$ from the midden edge. However, ST 20 and ST 21 were both positive even though they averaged more than $16 \mathrm{~m}$ away from the edge of the feature.

Overall, recovery was low at this site. Burned rock was the most commonly noted item in the shovel tests, being present in 23 of the 106 levels (21.7\%) excavated. Twenty-six chipped stone items were present in 17 levels (16\%). Mussel shell was the least common item as it was recorded in only 10 of the 106 levels (9.4\%) excavated. Roughly 21.9 grams of shell was collected from shovel testing. Finally, 63 of the 106 levels (59.4\%) lacked any recovery.

Figure 9-3 presents the percentage of the chipped stone items (black bars) and mussel shell (gray bars) by level. Note that in both cases the sample sizes are small, with only 26 chipped stone items and approximately 21.9 grams of mussel shell 


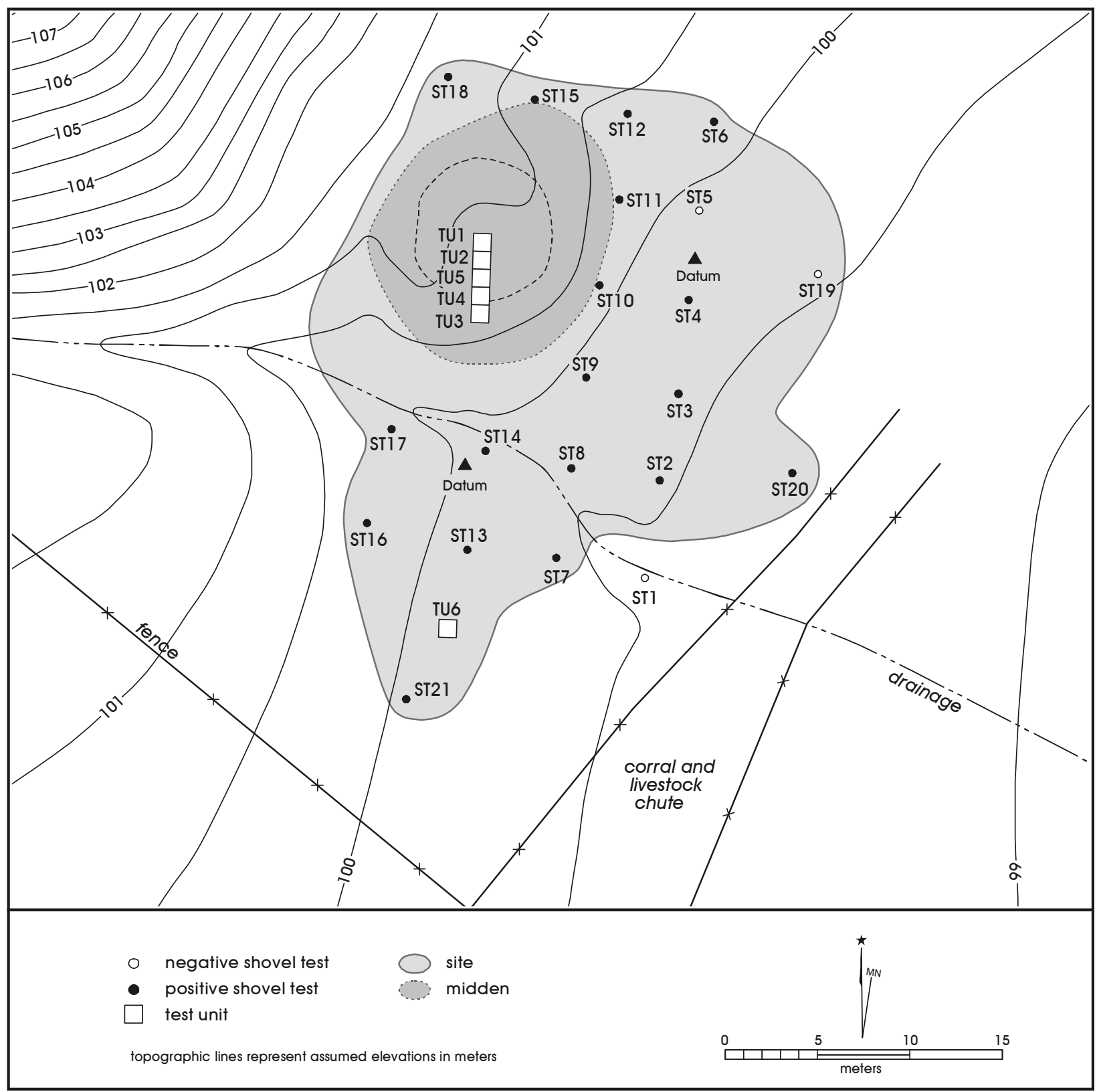

Figure 9-2. Locations of shovel tests and test units at 41BR522.

reflected in the figure. While chipped stone was present down to Level $5(40-50 \mathrm{cmbs})$, the figure clearly shows that the vertical distribution is concentrated within the upper portion of the site. Fifty-four percent $(\mathrm{n}=14)$ of the chipped stone items were recovered in Level $1(0-10 \mathrm{cmbs})$, and 19 of the 26 items (73\%) were within the upper $20 \mathrm{~cm}$ of the surface. The distribution of shell is very different, with the upper levels containing only $6 \%$ of the recovered shell, and roughly $52 \%$ concentrated between 30 and $40 \mathrm{cmbs}$. While burned rock was not counted, the presence/absence data suggest a distribution of this material more in line with the chipped stone data. Of the 42 levels excavated between 0 and $20 \mathrm{cmbs}, 12$ (28.6\%) had burned rock noted. Conversely, only 2 of the 20 levels $(10 \%)$ between 30 and $40 \mathrm{cmbs}$, the level with the highest concentration of mussel shell, had burned rock recorded as present. 


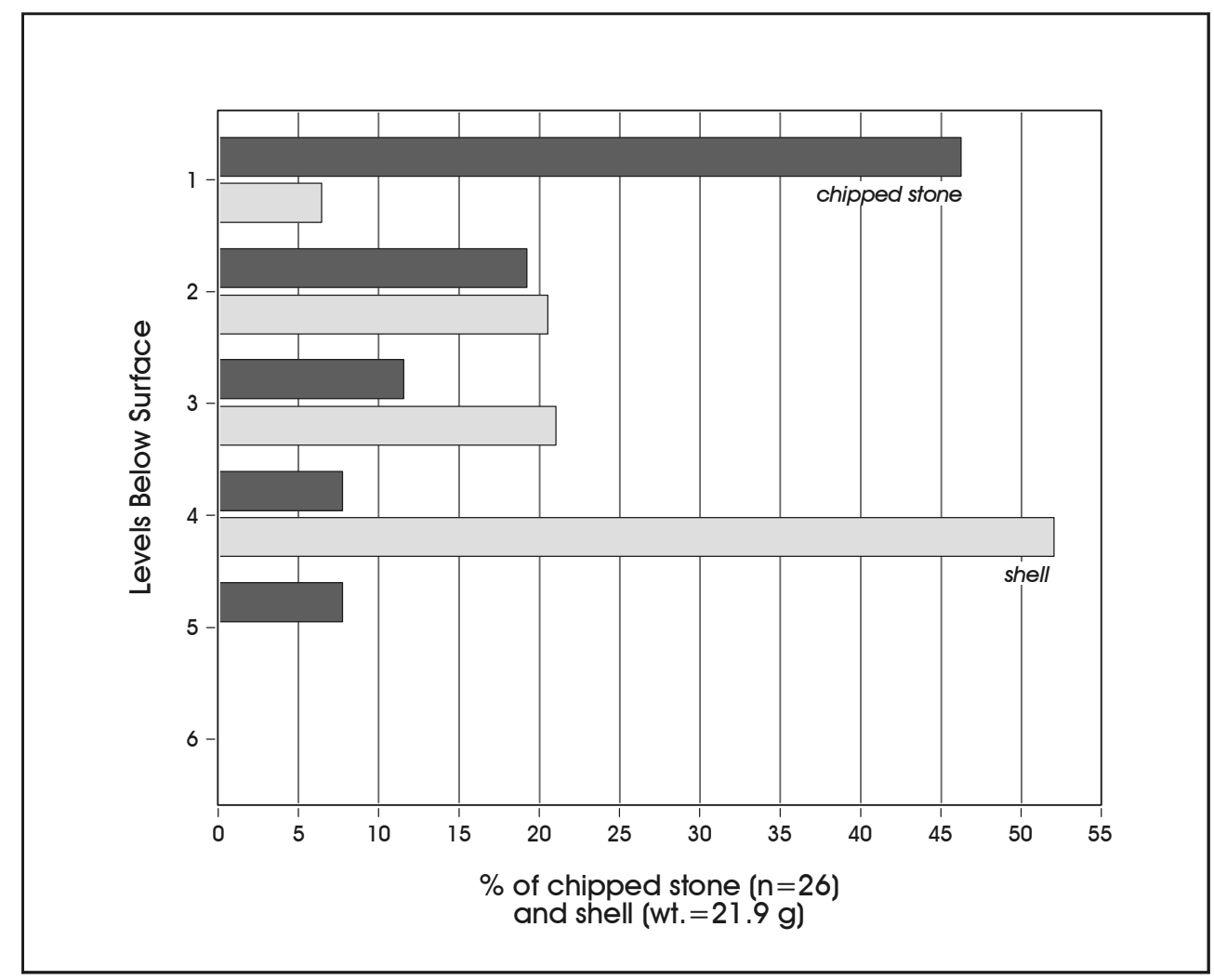

Figure 9-3. Percentages of chipped stone and mussel shell from shovel tests at 41BR522.

It is unclear why the vertical distribution of mussel shell is distinct when contrasted to the distribution of chipped stone and burned rock. A similar pattern was seen in the 41BR392 shovel test data, where chipped stone had a different distribution than mussel shell. In that case, however, shell was concentrated spatially near the midden, suggesting that shell was relevant to understanding midden and site use. While the overall sample size is smaller at 41BR522, no such concentration is evident. One possibility is that the mussel shell at this site is either not cultural or is cultural but unrelated to midden use. Mauldin et al. (2003) have argued that some component of the mussel shell recovered from other burned rock middens may not be cultural. Relying on amino acid racemization values, they suggest that much of the shell recovered from testing on 18 sites is probably too old to be associated with the middens, and that it may represent a low-level background distribution, or reflect the remains from earlier occupations. In any event, it is clear that the distribution of both the chipped stone and burned rock artifacts reflect a limited distribution, concentrated within the upper $20 \mathrm{~cm}$ of this site.

\section{Test Unit Results}

As noted previously, six 1-x-1-m test units were placed on the site, with five of these placed in the midden (TUs 1-5) and one (TU 6) placed to the south of the midden (see Figure 9-2). Roughly $2.55 \mathrm{~m}^{3}$ of sediment were removed from the five central units, with $2.31 \mathrm{~m}^{3}$ being within the midden, and $.24 \mathrm{~m}^{3}$ being below and above the midden fill. Approximately $.45 \mathrm{~m}^{3}$ was removed from TU 6 .

Test Units 1 through 5 were excavated to form a trench from the midden center through the midden ring. Figure 9-4 provides profiles of the eastern and western walls of the trench. Note that the western profile represents an inverse view of the trench, allowing for easy comparison of these unit profiles with their eastern counterparts. At a general level, excavation notes, as well as the profile drawing, suggest that three general depositional units are present (Figure 9-4). In the central portion of the midden, roughly $10 \mathrm{~cm}$ of what appears to be a colluvial fill, deposited from 


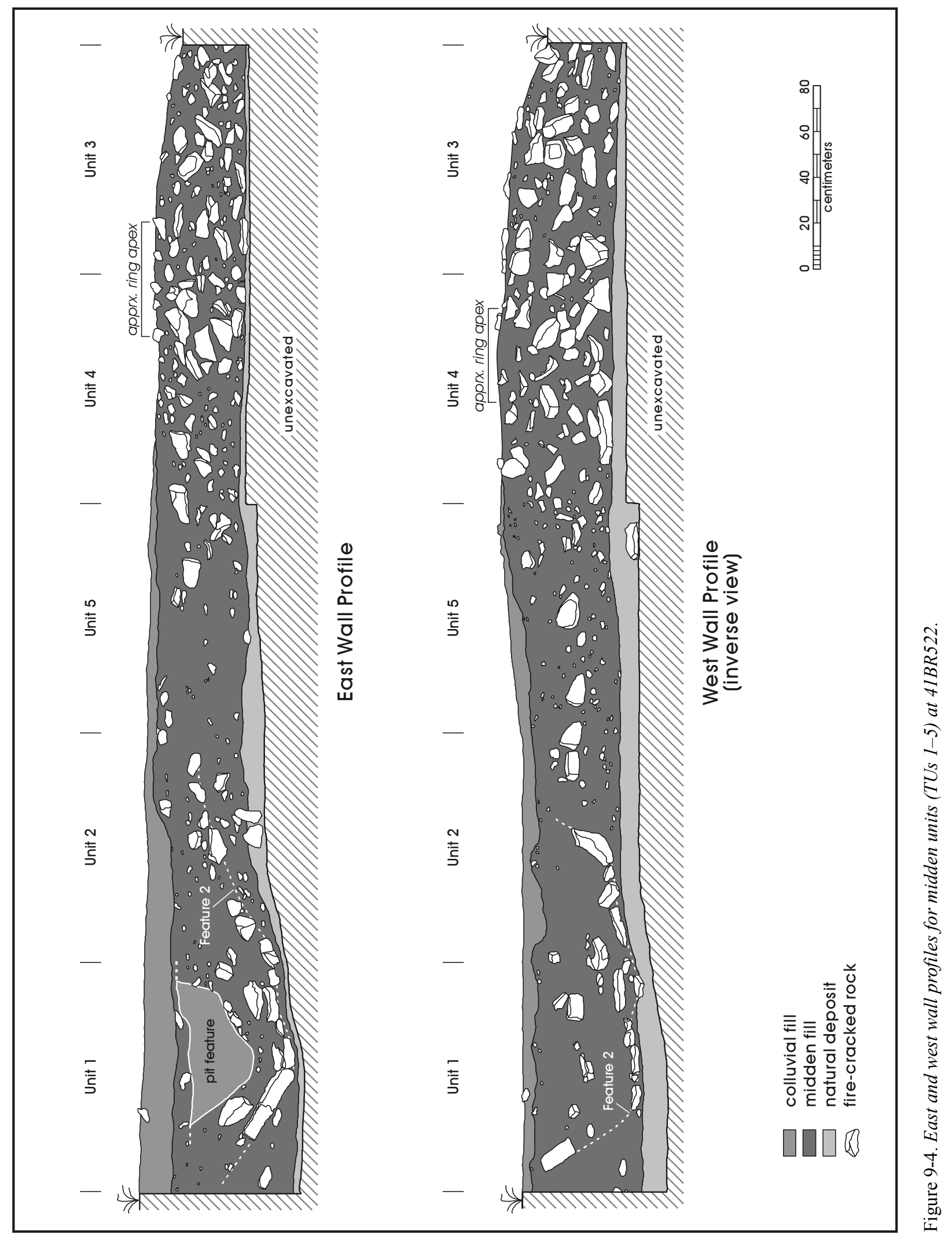


the upslope margin to the northeast of the feature, is present. The midden fill underlies this unit. The midden fill is a black to very dark gray sandy loam with a high density of burned rock. Charcoal, mussel shell, and chipped stone were noted in the fill. A third deposit, consisting of a well-sorted, sandy clay loam, tan to yellow in color, underlies the midden and seems to represent the natural surface (see Appendix D).

From excavations above and below the feature $\left(.24 \mathrm{~m}^{3}\right)$, artifacts were rare. No shell was recovered, and only two pieces of debitage were collected ( 8.3 items per cubic meter). Within the $2.31 \mathrm{~m}^{3}$ of sediment from the midden fill, 204.6 grams of mussel shell and 51 pieces of chipped stone (about 22 items per cubic meter) were recovered. Included in the chipped stone counts were a core, an edge-modified flake, and a Late Archaic (Montell) dart point. In addition, 200 pieces of animal bone were recovered from the midden deposits, with most (198) coming from TU 1, Levels 2 and 3 . The bones were in a tight cluster. These faunal remains were identified as armadillo (Dasypus novemcinctus) and are intrusive to the feature. Two unburned and unidentifiable mammal bones were also recovered from TU 5, Level 6. Although the overall sample size $(\mathrm{n}=51)$ is quite small given that over $2 \mathrm{~m}^{3}$ of fill was removed, most of the chipped stone $(\mathrm{n}=14)$ was recovered from Level $3(20-30 \mathrm{cmbd})$. Shell was also concentrated in this level, with $56 \%$ of the 204.6 grams coming from $20-30 \mathrm{cmbd}$. Fire-cracked rock was present throughout the deposits, with 147 pieces (about 612.5 items per cubic meter) that were equal to or greater than 1 inch in size assigned to non-midden deposits. Within the midden fill, burned and fire-cracked rocks were quite common, with nearly 10,000 pieces of fire-cracked rock (approximately 4,300 items per cubic meter) recorded.

While we will provide a more detailed discussion of the features in a following section, note that the entire burned rock midden was designated Feature 1. Feature 2 was assigned to a concentration of large fire-cracked rock found in TUs 1 and 2 (see Figure 9-4). There was also a pit feature within the deposits in $\mathrm{TU} 1$. While no formal feature number was assigned to this pit, the fill was a gray, sandy silt deposit.

Charcoal was common within the midden. Two charcoal samples were submitted to Beta Analytic for dating. Both samples came from TU 4, a unit from the feature ring. As discussed for 41BR392, the central midden units in these features are likely to be disturbed, while deposits that form the ring area have a lower probability of disturbance. Both samples were AMS dates. The initial sample, taken from between 36 and $40 \mathrm{cmbd}$ (Level 4), returned a corrected date of $810 \pm 40 \mathrm{BP}$. The second sample, collected at 45 cmbd (Level 5), returned a corrected date of $750 \pm 40 \mathrm{BP}$. Additional information on these specific dates can be found in Appendix A. Using the OxCal calibration program (Ramsey 2000), the Level 4 date calibrates to between A.D. 1210 and A.D. 1275 at 1-sigma. The Level 5 date calibrates to A.D. 1244-1292 at 1-sigma. These dates are statistically indistinguishable. If we assume that the dated material is in context and that the dated material reflects the age of the deposits in which it was found, these dates suggest the midden was in use sometime around A.D. 1250, well into the Late Prehistoric period. Note that the dates come from near the bottom of this ring unit. This suggests that the last use of the feature probably was sometime after that A.D. 1250 period. As discussed previously, this Late Prehistoric age for midden use is consistent with other dates on similar features at Camp Bowie (see Mauldin and Nickels 2003) as well as more regional patterns of burned rock middens dates (see Black and Creel 1997; Treece 1993), and with the dates for 41BR392 reported in Chapter 6. These dates, however, are much more recent than the presumed age of the Montell point. This point is commonly thought to date prior to A.D. 200 (Turner and Hester 1999:157). It is probable that the point is out of context.

Seven macrobotanical samples and three flotation samples were submitted to Dering for examination. The flotation samples were collected from TU 3, Levels 2 and 4, as well as from TU 2, Level 5. The macrobotanical samples came from a variety of locations within the midden. Charred wood and geophytes were recovered from these samples. As summarized in Appendix B, charred oak wood was recovered from TU 2, TU 4, and TU 5. Test Unit 3 contained legume wood that Dering (Appendix B) suggests probably represents mesquite. Intact bulbs and bulb leaf scale fragments were recovered from all five test units, and from a variety of different levels throughout the midden. Test Unit 1 contained 14 bulbs. Test Unit 2 contained five unidentified bulb fragments. Test Unit 3 contained a single bulb and two fragments of slag. As noted in Chapter 6 for the midden at 41BR392, the presence of this material probably reflects sap from plants (see Mauldin et al. 2003). Three samples from TU 4 contained a variety of bulbs and three leaf scale fragments, with the fragments identified as Eastern camas. Samples from TU 5 also contained bulbs. In all, 47 bulbs or bulb fragments were recovered from this midden, three of which were identified as camas.

Only a single unit, TU 6, was placed off-midden. The unit was positioned on the southern end of the site (see Figure 9-2). 
In Appendix D, Greaves notes that a very thin, recent A horizon is present near the top of the unit, with several poorly sorted, sandy loam depositional units, probably reflecting colluvial deposition from the nearby slope, as well as some alluvial slopewash, also identified. Within the $.45 \mathrm{~m}^{3}$ of sediment removed from this unit, 26 pieces of chipped stone debitage, one edge modified tool, and 1.9 grams of mussel shell were recovered. No charcoal was observed in the unit, and only a small amount of burned sandstone was noted. The unit was excavated to a depth of $51 \mathrm{cmbd}$, and all cultural material was concentrated within the upper $40 \mathrm{~cm}$ of the unit. The small amount of shell was recovered from Level 3 (20-30 cmbd), with 25 of the 27 pieces of chipped stone recovered from between 10 and $30 \mathrm{cmbd}$. Greaves (Appendix D) suggests that these artifacts may be deposited as soil clasts rather than indicating the location of a buried surface. That is, they may be the result of colluvial activity and not reflect a buried surface present at the time of the prehistoric occupation.

\section{Vertical Patterning of Material within the Midden Units}

As previously discussed, the vertical distributions of chipped stone and burned rock in shovel tests clearly indicate that most of the deposits are shallowly buried. While the overall recovery in shovel tests was low outside of the midden, artifacts seem to be concentrated within the upper $20 \mathrm{~cm}$ of the site's surface. Given that artifacts recovered in TU 6 may reflect a secondary, colluvial deposit, distributional data from this test unit adds little to our investigation of potential vertical patterning. We focus here, then, on patterning within the midden.

In our previous discussion of 41BR392, we used several classes of data, including chipped stone, mussel shell, burned rock, and sediment susceptibility, to investigate variability within the single excavation unit dug into the midden ring. The ring unit was selected as it has a lower probability of being disturbed, produced moderate sample sizes, and contained roughly $80 \mathrm{~cm}$ of midden deposits. The midden at 41BR522, however, presents a number of limitations for this type of investigation. Examination of the profiles in Figure 9-4 suggests that three test units, TU 3, TU 4, and TU 5, are probably within the ring area, while TUs 1 and 2 clearly contain a central feature, identified as Feature 2, as well as a smaller pit, not assigned a feature number. TU 4 appears to contain a significant portion of the material that created the apex of the ring (see Figure 9-4), and this unit was selected for a more detailed investigation of vertical patterning in artifacts. Note, however, that no sediment susceptibility samples were collected from the feature. In addition, we have a low number of chipped stone, with only six pieces recovered, and mussel shell is present in only two levels. Finally, the midden at 41BR522 is quite shallow, being about $45 \mathrm{~cm}$ in thickness. While some of these observations clearly have implications for the intensity and frequency of midden use, the shallow nature of the deposits and the low number of recovered chipped stone artifacts limits aspects of this investigation.

Figure 9-5 presents distributional data on burned rock, the only class of material common within the midden deposits in TU 4. The figure, which uses 2,626 fire-cracked rock between the sizes of one and six inches in diameter, presents patterns for three different size classes of rock. The distributions have been standardized and corrected for differential quantities of sediment in each level. As noted in Chapter 6 for 41BR392 (see also Mauldin et al. 2003), rocks between one and six inches in size are likely to be removed from the central feature area and deposited, along with ash, charcoal, and soil, to form the ring (see Figure 6-9). These three rock sizes, then, should be well suited for considering patterns of use in ring unit TU 4. An examination of the three distributions in the figure suggests that one clear peak, located in Level 2, is present in all three size classes. Such a peak is consistent with a period of intensive midden use near the top of the unit. Note also that a second peak is suggested near the bottom of TU 4 in Level 5 (Figure 9-5), at least in the 3-6 inch rock group. While represented by 336 pieces of fire-cracked rock, this size class has the smallest sample size of any of the three classes. As the other two size groups do not have the same pattern, it is difficult to interpret the 3-6 inch spike as reflecting a period of intensive use. Nevertheless, the evidence for a more intensive period of use associated with Level 2 is clear.

\section{Midden Structure}

As discussed in Chapter 6 for the burned rock midden at 41BR392 (see also Mauldin et al. 2003), burned rock middens thus far investigated at Camp Bowie are thought to represent repeatedly used earth ovens, probably related to the processing of geophytes. As noted in the previous section (see also Chapter 6, Figure 6-9), earth ovens should contain a central feature area dominated by larger rock, and a surrounding rock ring dominated by smaller rock that was discarded during feature maintenance. As shown previously in Figure 9-4, the burned rock midden at 41BR522 provides an excellent example of this central feature and surrounding ring. The central feature, defined by a line of large, firecracked sandstone rocks, was designated Feature 2. The 


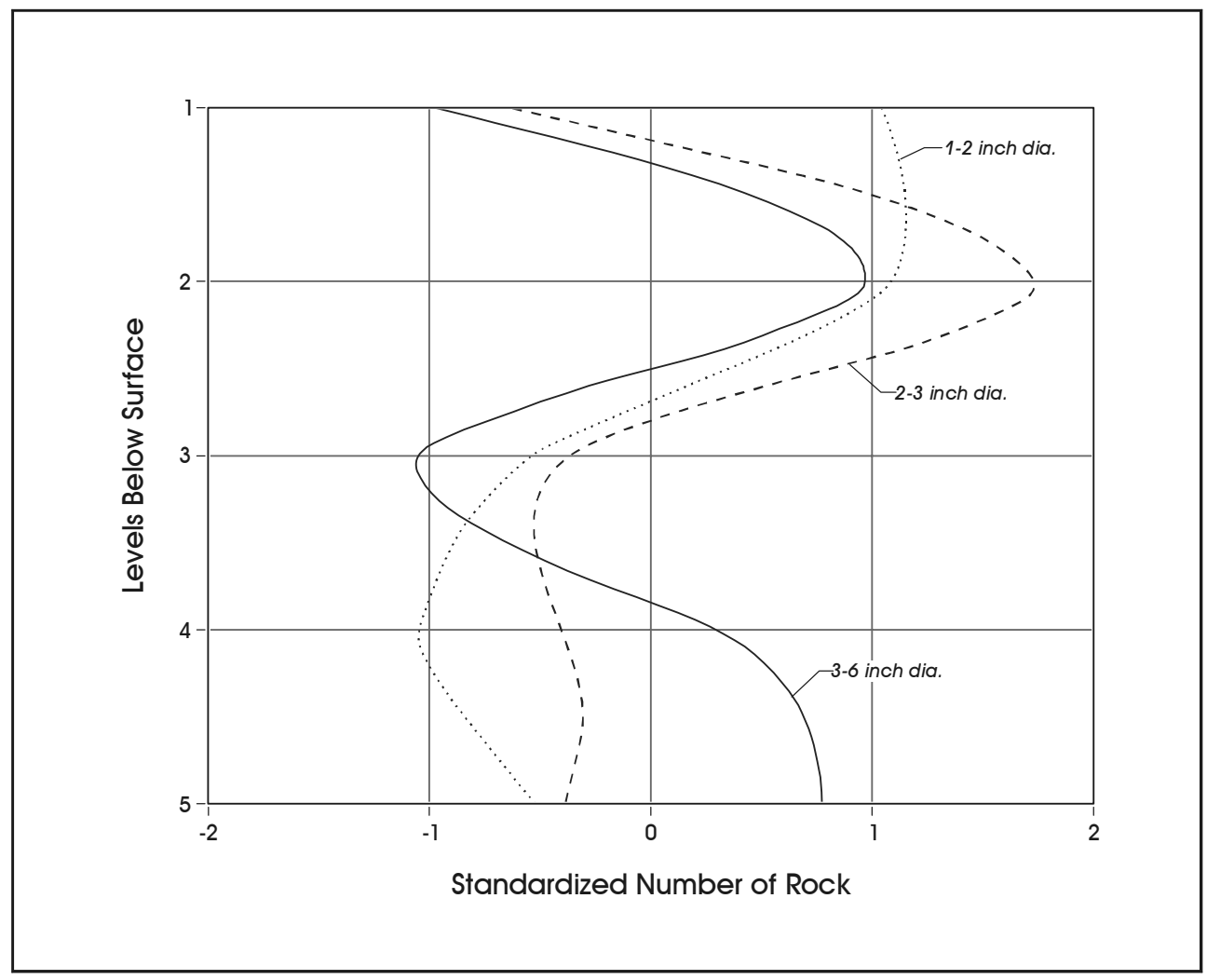

Figure 9-5. Standardized number of rock from Test Unit 4 at 41 BR522.

feature was visible in both the eastern and western profiles of TUs 1 and 2. The sandstone rocks seem to define a basinshaped pit, reaching a maximum depth of roughly $60 \mathrm{cmbd}$ in TU 1. Figure 9-6 (top) provides an enlargement of the TU 1 and TU 2 section of the western profile. Below the profile, we provide a plan view for these same two units, reflecting depths of approximately 20 to $50 \mathrm{cmbd}$. The nature of this central feature is clearly reflected in the plan and profile comparisons. The central feature (Feature 2) is rock lined, about $2 \mathrm{~m}$ in diameter, and roughly $45 \mathrm{~cm}$ deep. The small pit feature, not assigned a number in the field, may reflect the infilling of a pit originally dug to remove the cooked geophytes. All of these components are consistent with the notion that this feature represents an earth oven.

Figure 9-7 considers rock size data using the three medium size grades (1-2 inches, 2-3 inches, 3-6 inches) that further supports this assessment. With the exception of a single case, the 3-6 inch size class in TU 1 relative to the same size class in TU 5, medium-sized rocks are consistently underrepresented in the central feature units and over-represented in the ring units. Figure 9-8 presents patterns in burned rock in the 6-inch or greater size class. The figure shows that with the exception of TU 2 (center) and TU 4 (ring), where rock counts are essentially identical, central units have more large rock than expected relative to ring units. The differences are actually much greater than suggested by the Figure 9-8 patterns, as the central units had several large slabs in excess of 12 inches in diameter, a size range not represented in the ring where maximum size seldom exceeded seven inches. Finally, Figure 9-9 presents the weights, by unit, for the burned rock less than one inch in size. Here, the patterns are not as clear-cut. Consistent with our expectations that maintenance of the central feature may overlook the smallest size range, TU 1 has the greatest weight of small rocks. In addition, when both central units are contrasted to all three ring units, the central units do have a greater average weight in the small size range. However, not consistent with the model is the TU 2 weights, as both ring units, TUs 4 and 5 , exceed this central feature unit. In spite of these inconsistencies, the predominance of the evidence is consistent with the earth oven model. 


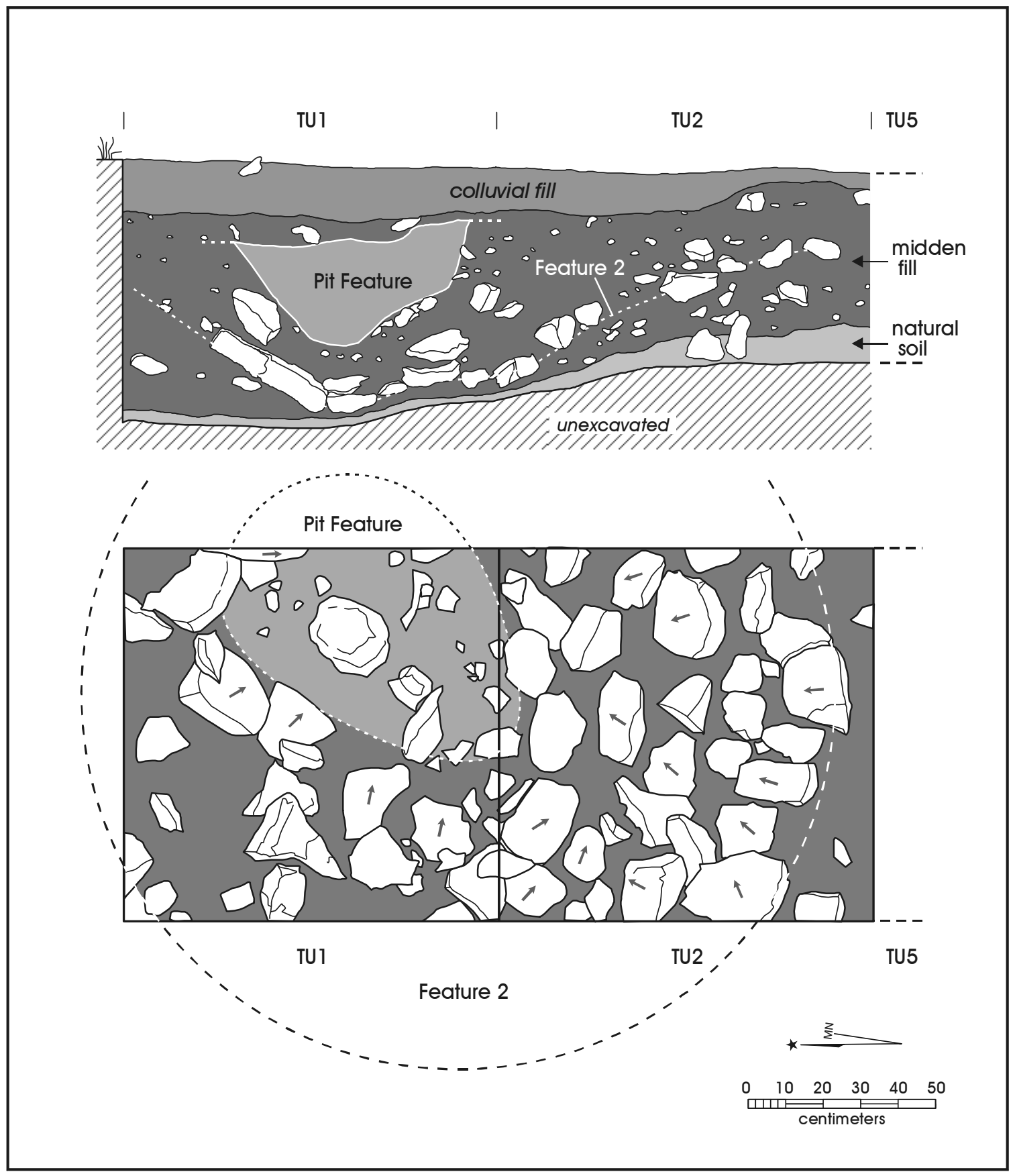

Figure 9-6. Detail of interior ring construction of the midden at 41 BR522. 


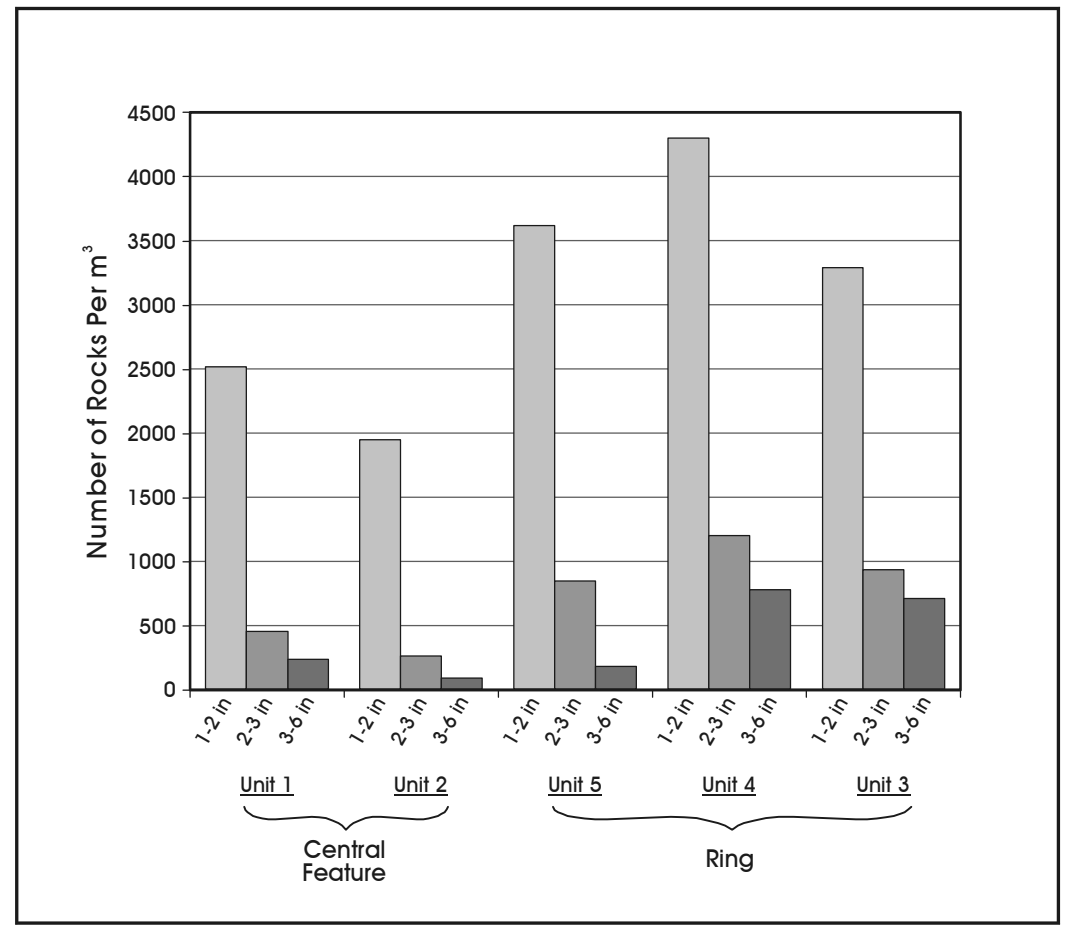

Figure 9-7. Fire-cracked rock size in midden units, 41BR522.

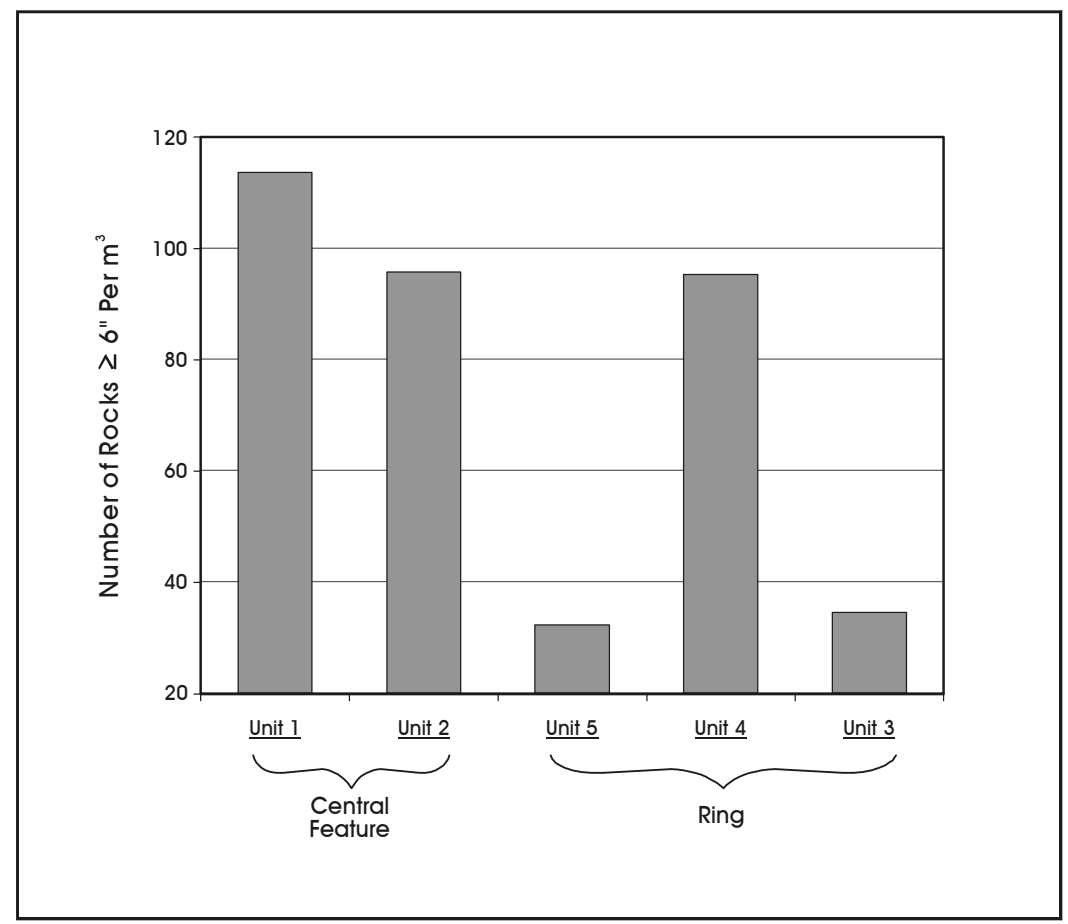

Figure 9-8. Number of fire-cracked rocks 6 inches or greater in size from midden units at 41 BR522. 


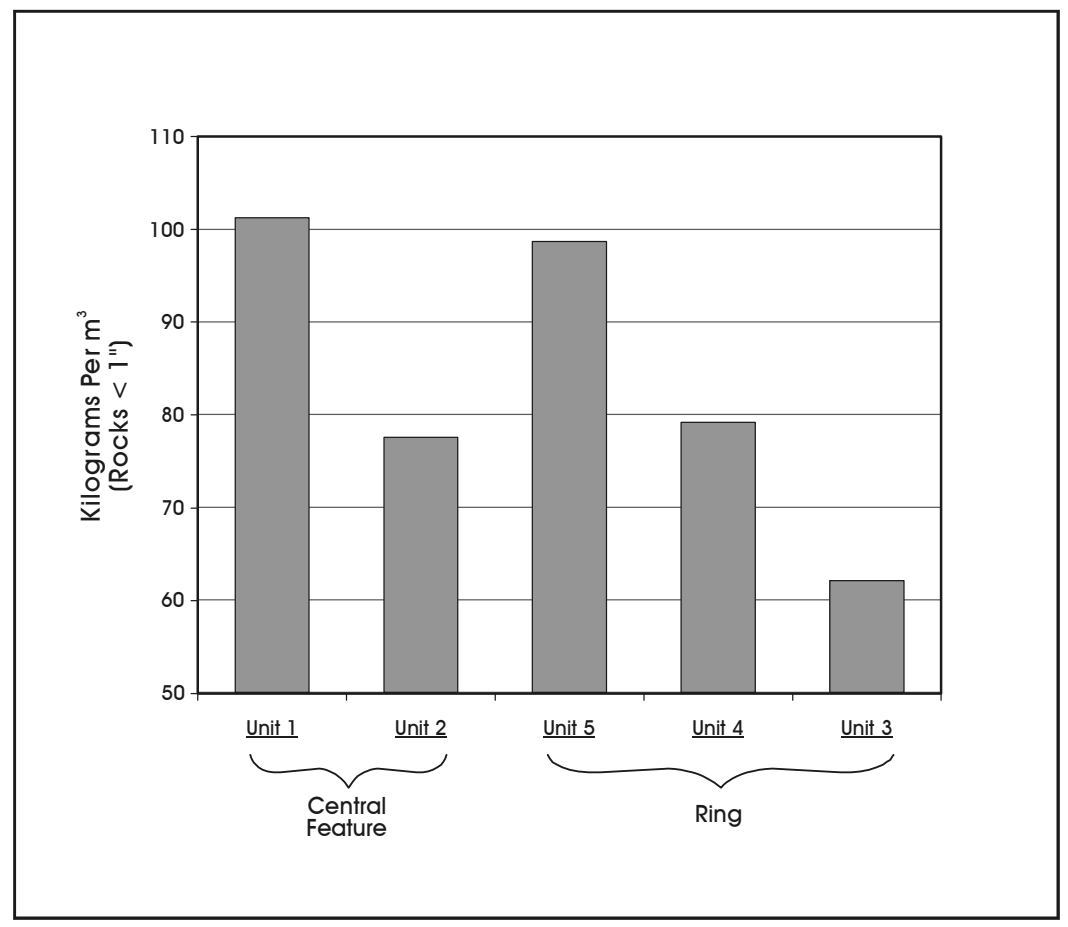

Figure 9-9. Weights of fire-cracked rocks less than 1 inch in size from midden units at $41 B R 522$.

\section{The Chipped Stone Assemblage}

One hundred and one pieces of debitage, one core, a retouched/modified flake, two biface fragments, and a projectile point were recovered from CAR's most recent testing at 41BR522. The debitage and tool assemblage seems to suggest a more generalized reduction pattern.

\section{Debitage Patterns}

Cortex was absent on $61 \%$ of the debitage $(n=62)$, while 11 items $(10.9 \%)$ had more than $50 \%$ dorsal cortex cover. Table 9-1 presents the cortex patterns at this site and contrasts them to the combined collections from the remaining three sites tested on this project. As with previous cross-tabulations, the standardized adjusted residuals are included below each cell. Adjusted residual values exceeding an absolute value of 1.96 suggests that this cell is significantly different at a probability exceeding .05 (see Everitt 1977). All of the cells in the table are significantly different. Cortex is over-represented on 41BR522 relative to other sites in all categories.

The thickness/length ratio for the 38 complete flakes is .228 . The ratio for the combined assemblages for the remaining three sites is .188. While higher ratios tend to reflect earlier reduction, both values are within ranges for assemblages characterized by late reduction activities.

Table 9-2 presents the division of flakes by flake type for 41BR522, and contrasts them with the combined assemblage generated from the remaining three sites. Examination of the adjusted residuals shows that there are significant differences in the number of biface thinning flakes and the number of biface manufacturing flakes. No other significant values are reflected in the table. The significant underrepresentation of these flakes at $41 \mathrm{BR} 522$ suggests that less late-stage bifacial work was conducted at this site relative to the combined assemblages from the other sites. Overall, then, the chipped stone debitage shows no strong tendency for either a focus on bifacial work or a focus on core reduction.

Finally, note that unlike the assemblage from the other burned rock midden site, 41BR392, the assemblage from 41BR522 shows no significant difference in the frequency of heating observed on debitage collected from the midden relative to non-midden areas. Evidence of heating was present on only 18 of the 101 pieces of debitage (17.8\%) examined from the site. Eight of these (47\%) were from within the midden, and the midden contained roughly $49 \%$ 
Table 9-1. Counts and Adjusted Residual Values for Cortex Patterns, 41BR522 and Remaining Sites

\begin{tabular}{|c|c|c|c|c|c|c|}
\hline & \multicolumn{3}{|c|}{ Cortex Percentage } & \multirow{2}{*}{$\begin{array}{c}\text { Total } \\
\text { Counts } \\
\end{array}$} & \multirow[b]{2}{*}{ Percentage } \\
\hline & & $0 \%$ & $1-50 \%$ & $51-100 \%$ & & \\
\hline $\begin{array}{l}\text { All Other } \\
\text { Sites }\end{array}$ & $\begin{array}{l}\text { Raw Counts } \\
\text { Adjusted Residual }\end{array}$ & $\begin{array}{l}1179 \\
3.53 \\
\end{array}$ & $\begin{array}{c}276 \\
-2.44 \\
\end{array}$ & $\begin{array}{r}79 \\
-2.45 \\
\end{array}$ & 1534 & $93.82 \%$ \\
\hline 41BR522 & $\begin{array}{l}\text { Raw Counts } \\
\text { Adjusted Residual }\end{array}$ & $\begin{array}{r}62 \\
-3.53 \\
\end{array}$ & $\begin{array}{r}28 \\
2.44 \\
\end{array}$ & $\begin{array}{c}11 \\
2.45 \\
\end{array}$ & 101 & $6.18 \%$ \\
\hline & Total Counts & 1241 & 304 & 90 & 1635 & \\
\hline & Percentage & $75.90 \%$ & $18.59 \%$ & $5.50 \%$ & & \\
\hline
\end{tabular}

Table 9-2. Counts and Adjusted Residual Values for Flake Types, 41BR522 and Remaining Sites

\begin{tabular}{|c|c|c|c|c|c|c|c|c|}
\hline & \multicolumn{5}{|c|}{ Flake Types } & \multirow[b]{2}{*}{$\begin{array}{c}\text { Total } \\
\text { Counts } \\
\end{array}$} & \multirow[b]{2}{*}{ Percentage } \\
\hline & & $\begin{array}{c}\text { Angular } \\
\text { Debris }\end{array}$ & $\begin{array}{c}\text { Biface } \\
\text { Manufacture }\end{array}$ & $\begin{array}{c}\text { Biface } \\
\text { Thinning }\end{array}$ & $\begin{array}{c}\text { Core } \\
\text { Preparation } \\
\end{array}$ & $\begin{array}{c}\text { Platform } \\
\text { Preparation }\end{array}$ & & \\
\hline $\begin{array}{l}\text { All Other } \\
\text { Sites }\end{array}$ & $\begin{array}{l}\text { Raw Counts } \\
\text { Adjusted Residual }\end{array}$ & $\begin{array}{c}54 \\
-1.75 \\
\end{array}$ & $\begin{array}{r}130 \\
2.20 \\
\end{array}$ & $\begin{array}{c}46 \\
2.13 \\
\end{array}$ & $\begin{array}{c}13 \\
-0.69 \\
\end{array}$ & $\begin{array}{c}408 \\
-1.64 \\
\end{array}$ & 651 & $91.56 \%$ \\
\hline \multirow[t]{3}{*}{ 41BR522 } & $\begin{array}{l}\text { Raw Counts } \\
\text { Adjusted Residual } \\
\end{array}$ & $\begin{array}{r}9 \\
1.75 \\
\end{array}$ & $\begin{array}{r}5 \\
-2.20 \\
\end{array}$ & $\begin{array}{c}0 \\
-2.13 \\
\end{array}$ & $\begin{array}{c}2 \\
0.69 \\
\end{array}$ & $\begin{array}{c}44 \\
1.64 \\
\end{array}$ & 60 & $8.44 \%$ \\
\hline & Total Counts & 63 & 135 & 46 & 15 & 452 & 711 & \\
\hline & Percentage & $8.9 \%$ & $18.9 \%$ & $6.5 \%$ & $2.1 \%$ & $63.6 \%$ & & \\
\hline
\end{tabular}

\section{Summary}

of the debitage recovered from the site. The lack of debitage with evidence of heating from within the midden is surprising, especially in light of the pattern seen at 41BR392. This may be related to the potential that the midden on 41BR522 was used for a relatively short time span relative to other middens. A relatively short use life would potentially result in lower frequencies of incorporation of material offmidden into midden sediments.

\section{Tools}

Four tools were recovered from our testing at this site. One retouched/modified flake (Figure 9-10a) was recovered from TU 1, a distal biface fragment came from ST 16, Level 1 (Figure 9-10b), and a medial biface fragment was recovered from TU 6, Level 2 (Figure 9-10c). In addition, a Montell point was collected from TU 1, Level 4 (Figure 9-10d). The point is a proximal fragment missing the tip due to a manufacture break. This point is sharply barbed with a bifurcated expanding stem and dates to the Late Archaic, with a likely date range of approximately 1000 B.C. to A.D. 200 (Turner and Hester 1999).
Site 41BR522 was originally recorded by Greaves (2002: 17-21) who documented a single, sandstone burned rock midden at this site. The midden is oval, roughly $14 \mathrm{~m}$ by 15 $\mathrm{m}$ in size, and has a clear central depression. The site also contains a low density of chipped stone debitage. A small number of shovel tests confirmed that the midden has some depth, and that subsurface deposits are present outside of the feature. On the basis of the burned rock feature, Greaves (2002) recommended that testing, focused on the midden, should be conducted to clarify the eligibility status of this site. For the current project, both shovel tests and test excavation units were placed on 41BR522. CAR's most recent work at this site produced over 100 pieces of chipped stone, including two biface fragments and a single Late Archaic Montell point. The debitage shows no real tendency for either late-stage biface reduction or core reduction, suggesting a more generalized reduction strategy was practiced at the site. Mussel shell was collected from a variety of different locations, though the shell seemed to have a different distribution than either the chipped stone or the fire-cracked rock. In addition, we measured sizes of nearly 10,000 pieces of burned rock from the midden feature. 
Patterning in shovel test data suggests that outside of the midden the distribution of both the chipped stone and burned rock artifacts is concentrated within the upper $20 \mathrm{~cm}$ of this site. The vertical distribution of 1-6 inch fire-cracked rock within $\mathrm{TU} 4$, a ring unit within the midden, shows that a single peak is present in all three size classes. This suggests a single pattern of intensive use may be reflected by the feature rock. An analysis of burned rock sizes within the midden is consistent with the earth oven model in which large rocks are used as heating elements and smaller, fractured rock discarded to form the midden ring. This is supported by the documentation of Feature 2, a well-preserved, slab-lined, central feature. Two radiocarbon dates from the lower portion of the feature demonstrate that the midden was probably in use sometime around A.D. 1250, well into the Late Prehistoric period. Given these dates, the single Montell point, collected from within the midden and dating to the Late Archaic, is probably out of context and does not reflect any significant Archaic period occupation at the location. Ethnobotanical remains were present in the midden in significant quantity. These data are consistent with the use of the midden to process geophytes, including Eastern camas.

It is our assessment that the burned rock midden at 41BR522 remains largely intact. The feature has excellent preservation of charcoal and botanical remains. In addition, it appears to represent a relatively short-term use of this type of feature. The midden has excellent information on the structure of these oven features, including a well-defined

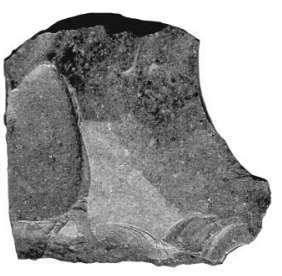

a

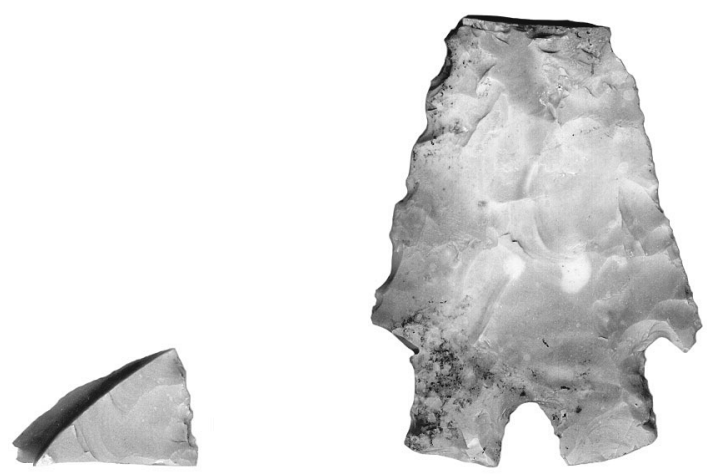

C

d

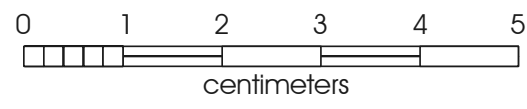

Figure 9-10. Tools recovered from 41BR522. a) retouched/modified flake; b-c) biface fragments; d) Montell point. central feature area. This site represents our first chance to examine a relatively short-term use of this feature type. 



\title{
Chapter 10: $\quad$ Summary and Recommendations
}

\author{
Jason D. Weston and Raymond P. Mauldin
}

\section{Introduction}

As discussed in Chapter 4, the primary task identified in the scope of work for this project involved the eligibility assessment of the four tested sites on Camp Bowie for possible inclusion to the National Register of Historic Places (NRHP) and possible designation as State Archeological Landmarks (SALs). While a variety of criteria are potentially relevant to both SAL designation and NRHP eligibility, the primary criterion that will be used in the assessment for NRHP eligibility and SAL designation centered on the potential for a site to yield information important in prehistory or history (NRHP) and the potential for a site to contribute to a better understanding of Texas prehistory or history (SAL). In Chapter 4, we outlined four different data patterns that were used to assess the integrity of the archaeological deposits on this project. These included the following: 1) the presence of buried deposits and/or the presence of surface deposits with distinctive concentrations of material; 2) subsurface patterns of artifacts indicating peaks of deposition that may indicate distinctive periods of occupation; 3) the presence of recognizable features, especially those that have minimal evidence of disturbance; and 4) data on the presence, nature, and amount of turbation within the site sediments, including both natural (e.g., animal burrowing, erosion, deposition) and cultural (e.g., modern activity, historic intrusions) processes. In addition, we identified three research areas relevant to the two sites with burned rock middens, sites 41BR392 and 41BR522, and two research areas relevant to sites 41BR471 and 41BR500. For the burned rock midden sites, we suggested that the presence of data for assessing questions concerning the formation of the features, the function of the features, and the chronological placement of the features should guide our evaluation. For sites 41BR471 and 41BR500, we suggested that the presence of data for addressing questions of chronological placement and subsistence should guide our evaluation. This chapter, then, assesses the sites in terms of their integrity and their data potential for addressing these research questions, and makes appropriate recommendations regarding NRHP eligibility and SAL designation.

\section{BR392}

As summarized in Chapter 6, 41BR392 contained both a prehistoric and a historic component, though CAR's work focused only on the prehistoric component. The principal element of our testing centered on a large (12 m x $15 \mathrm{~m})$ burned rock midden. It was on the basis of that feature that Greaves (2002) recommended the site for testing. Shovel tests and 1-x-1-m test units were excavated at the site. In the following paragraphs we summarize both the integrity of the deposits and the potential of the data contained in the site for addressing questions centered on burned rock middens. Finally, a short summary of possible mitigation strategies for this location is presented.

The integrity of the site deposits at 41BR392 appears to be good. Patterning in artifacts outside of the midden suggests that a single occupation surface, buried by $20-30 \mathrm{~cm}$ of sediment, is present at this site. This observation is consistent with geomorphic observations and was further supported by data provided by magnetic sediment susceptibility analysis. Vertical distribution of debitage, burned rock, and shell, again supported by magnetic sediment susceptibility values, suggests that there were two periods of intensive midden use. No extensive turbation was observed in the midden deposits, and while historic material was present in the prehistoric portion of the site, including a rock wall impacting the northern end of the midden, the distribution of the small number of historic artifacts is limited. The rock wall has certainly impacted the northern fringe of the midden, but the vast majority of the deposits have not been impacted.

Our testing work further suggested that the midden at 41BR392 contains data relevant to addressing questions centered on burned rock midden formation, function, and chronology. An analysis of burned rock sizes and distribution from the three 1-x-1-m units excavated within the midden is consistent with the earth oven model in which large rocks are used as heating elements and smaller, fractured rocks are discarded to the exterior ring. Our limited ethnobotanical sampling from the midden demonstrates that charred remains 
are present in the deposits, including both identifiable charcoal and economically important data (geophytes). Radiocarbon dates were obtained from one portion of the midden. These dates demonstrate that midden use probably occurred between A.D. 770 and A.D. 990, during the early portion of the Late Prehistoric period, though later uses may also be present.

Based on our limited testing at this site, it is our assessment that the overall integrity of the archaeological deposits is good. Furthermore, the burned rock midden at 41BR392 remains largely intact and contains data relevant to assessing current research questions centered on midden formation, function, and chronology. As such, we recommend that the prehistoric portion of site $41 \mathrm{BR} 392$ be considered eligible for NRHP inclusion under criterion D. The site has yielded, and has the potential to yield, information important to prehistory. In addition, we recommend that designation as a SAL is warranted as $41 \mathrm{BR} 392$ has yielded, and has the potential to yield, information that can contribute to a better understanding of Texas prehistory.

Either avoidance of this site location by training activities, or some form of mitigation at this site, primarily centered on the midden, will be necessary. Clearly, avoidance will be the least costly alternative. However, if avoidance is not possible, then data recovery procedures should be designed to acquire detailed information on site and midden chronology, data on subsistence, and detailed information on midden structure.

In the case of 41BR392, our testing efforts have demonstrated that prehistoric off-midden deposits, while clearly present, are minimal. No features were uncovered, though evidence for an outside surface was clearly present. Consequently, data recovery efforts should focus on the midden, though an attempt should be made to link the outside surface more closely with the midden construction, and search for features potentially located near the midden, but not uncovered during testing. We have also found evidence, based on rock size data, for a central feature, though in the case of 41BR392 the feature is not as well defined as on site 41BR522. Given these conditions, one possible mitigation strategy would be to rely on a combination of mechanical trenching and scraping, as well as large-scale exposure with hand-excavated units. For example, a backhoe trench could be cut through the midden running north/south. The trench could be centered along the 1-x-2-m testing units, minimizing any additional damage to the central area. After profiling, a second trench, running perpendicular to the first, could be cut. This second trench could be positioned off the midden center, and the two trenches could essentially isolate a section of the midden for hand excavation. Figure 10-1 lays out this possible scenario. Hand-excavated units, working off the two trenches, could then be excavated to gather the required data. These units should be excavated through the midden deposits, and the excavated grid should extend out beyond the midden into the outside site surface. If this plan were to be adopted, then approximately 52 additional hand-excavated units would be placed at the site. Following the hand excavation, we would suggest that a front-end loader or backhoe be used to systematically dismantle the remaining portions of the midden. The dismantling should be done in several stages, essentially removing slices of the feature down to a given depth. Plan views, emphasizing rock density and size, could then be made at several stages of this operation. These plan views would provide additional information on midden construction. Finally, we would suggest mechanical scraping of areas around the midden as a final component of this data recovery strategy. This scraping would be designed to identify any smaller features that may be near the burned rock midden.

The mechanical work and the hand-excavation of contiguous units should produce a variety of different data sets that could be used to investigate midden chronology, construction, and subsistence. We would specifically encourage the collection, processing, and analysis of a large number of flotation samples, as well as the dating of selected samples of geophytes from a variety of proveniences. The potential for lipid residue analyses of rock should also be considered (see Malainey 1997; Quigg 1999). Finally, rock size data should be collected from all hand-excavated units. The combinations of detailed flotation analysis, possible information from lipid residues, direct dating of geophytes, and rock size data from contiguous units, coupled with potential data such as faunal material and information of subsistence provided by lithic artifacts, should provide critical data for the investigation. We suggest that these procedures would effectively mitigate the prehistoric component at 41BR392.

\section{BR471}

As summarized in Chapter 7, site 41BR471 contained a prehistoric lithic scatter that probably dates to the Late Prehistoric. The principal element of our work at this site involved six controlled surface collection areas, roughly $3.14 \mathrm{~m}^{2}$ in area, and the excavation of two 1-x-1-m test units. These methods were designed to gather data on the surface 


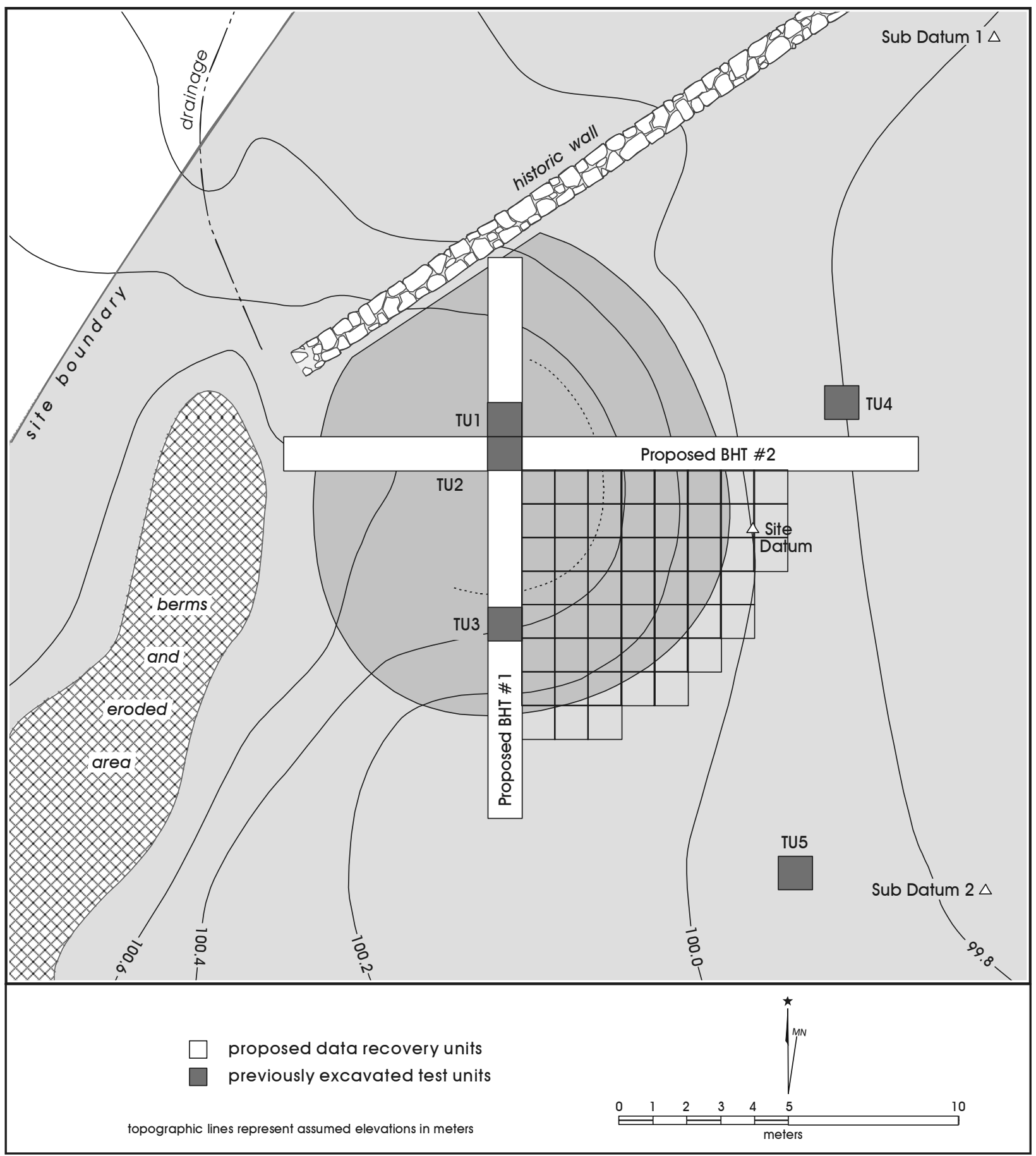

Figure 10-1. Proposed data recovery excavations on 41 BR392. 
distribution of chipped stone, and explore the potential for deeper deposits at the site. It was on the basis of the presence of a surface concentration of chipped stone, potentially dating to the Late Prehistoric, that additional testing was recommended (Greaves 2002).

The integrity of the site deposits appears to be poor. Only three items were found subsurface, and surface clusters are not discrete, but appear to represent high to moderate density areas within a lower density scatter. No features were observed. While no geomorphic observations were made in conjunction with the current work, based on previous work (Greaves 2002), as well as observations by the field crews, the site is eroded and deflated.

Our testing and surface collections at this site suggest that 41BR471 is unlikely to contain any additional data relevant to research questions concerning either chronological placement of the remains or to subsistence. The site is essentially a surface lithic scatter with no buried material. No charcoal, faunal, or ethnobotanical data were collected. In addition, no new diagnostic artifacts were recovered.

Based on our limited work at this site, it is our assessment that the overall integrity of the archaeological deposits is poor. Furthermore, the data available are simply not relevant to assessing current research questions centered on chronological placement of the assemblage or concerns with subsistence. As such, we do not recommend that site 41BR471 be considered eligible for NRHP inclusion under any criteria. Any potentially relevant data have been recovered through the surface collection. In addition, we do not recommend that designation as a SAL is warranted for this site. In our opinion, no additional work should be conducted at this location.

\section{BR500}

As summarized in Chapter 8,41BR500 is a moderately sized scatter of chipped stone debitage and tools, ground stone, and scattered burned rock. Much of the site has been disturbed by plowing, as well as by the construction of a berm. Based on the recovery of flakes in association with several pieces of burned sandstone, Mauldin and Broehm (2001:21-23) recommended the undisturbed portion of the site for testing. Testing involved shovel tests and excavation of four 1-x-1-m test units. These efforts recovered over 1,000 pieces unmodified lithic debitage, 16 bifaces, five dart points, a chopper, a scraper, two cores, and a hammerstone/mano.
The integrity of the site deposits appears to be poor. Results of the shovel testing demonstrated that subsurface deposits are present down to approximately $70 \mathrm{cmbs}$ at several places on the undisturbed portion of the site. However, no clearly distinct subsurface concentrations were present, though three minor peaks in artifact density were observed. Test Units 1 , 2 , and 3 explored the potential feature area identified on the previous survey. While scattered burned rock and chipped stone debris were recovered at this location, no clearly distinct feature could be identified. The material appears to represent a secondary deposit rather than an intact feature. However, one feature, consisting of a small charcoal stain with some burned rock, was identified in a fourth test unit from this site. A radiocarbon date was recovered from this area that suggested a Late Prehistoric use (circa A.D. 720890). However, several diagnostic artifacts, including a Middle Archaic Nolan point and two Late Archaic points, were recovered from above the Late Prehistoric date suggesting some level of disturbance. Some additional evidence for displacement of artifacts in this unit was present in the distribution of debitage, as well as in the magnetic susceptibility values. Coupled with the observation that the diagnostic points do not pattern with the radiocarbon date, it is probable that the artifactual material in this test unit, like the TU 1-3 area, is probably out of context. Finally, note that plowing and related activities have disturbed roughly $75 \%$ of the site.

CAR's work at 41BR500 was conducted in the context of two general research domains involving chronology and subsistence. Site 41BR500 clearly contains data relevant to addressing chronological concerns, including a variety of diagnostic points and a feature which has yielded a radiocarbon date. However, as noted, the integrity of much of this data is greatly reduced. Data directly related to subsistence concerns is not present from this site. No ethnobotanical material was recovered from the two flotation samples submitted from Feature 1. In addition, no bone was collected from any of the test units at this site.

Based on our work at this site, it is our assessment that the overall integrity of the archaeological deposits at 41BR500 is poor. Furthermore, while there are some data available to assess current research questions centered on chronological placement of the assemblage, the poor integrity of the deposits greatly limits the utility of those data. Data relevant to considerations of subsistence are not present. As such, we do not recommend that site $41 \mathrm{BR} 500$ be considered eligible for NRHP inclusion under any criteria. In addition, we do not recommend that designation as a SAL is warranted 
for this site. In our opinion, no additional work should be conducted at this location.

\section{BR522}

As summarized in the previous chapter, site 41BR522, like site 41BR392, contains a burned rock midden. The midden is a low, circular sandstone accumulation of burned rock, roughly $14 \mathrm{~m}$ by $15 \mathrm{~m}$ in size, with a clearly visible central depression. A low-density surface scatter of lithics surrounds the midden area. It was on the basis of the burned rock midden that Greaves (2002) recommended the site for testing. Shovel tests and six $1-\mathrm{x}-1-\mathrm{m}$ test units were excavated at the site.

The integrity of the site deposits appears to be excellent. Patterning in shovel test data from outside of the midden demonstrates a limited distribution of chipped stone and burned rock artifacts, most of which is concentrated within the upper $20 \mathrm{~cm}$ of the deposits. Within the midden, distribution of fire-cracked rock suggests a single period of intensive use may be reflected in the feature. Furthermore, a well-preserved, slab-lined, central feature (Feature 2) was recognized in the central portion of the midden. Finally, while rodent disturbance was noted, it was not extensive and does not seem to have impacted the integrity of the deposits.

Our testing work further suggests that the midden at 41BR522 contains data relevant to addressing questions centered on burned rock midden formation, function, and chronology. Two radiocarbon dates from the lower portion of the midden demonstrate a Late Prehistoric period of use. Ethnobotanical remains were recovered from the midden in significant quantity, and seem to reflect the use of the midden to process geophytes. An analysis of burned rock sizes within the midden is consistent with the earth oven model, and this assessment is supported by the documentation of the slablined central feature.

Based on our limited testing at this site, it is our assessment that the overall integrity of the archaeological deposits is excellent. The burned rock midden at 41BR522 exhibits excellent structural preservation and has a well-defined central feature. The botanical preservation is excellent and radiocarbon dates have been obtained from the feature. The burned rock midden is intact and contains data relevant to assessing current research questions centered on midden formation, function, and chronology. As such, we recommend that the prehistoric portion of site 41BR522 be considered eligible for NRHP inclusion under criterion $\mathrm{D}$, as the site has yielded, and has the potential to yield, information important to prehistory. In addition, we recommend that designation as a SAL is warranted as 41BR522 has yielded, and has the potential to yield, information that can contribute to a better understanding of Texas prehistory.

Either avoidance of this site location by training activities, or some form of mitigation at this site, primarily centered on the midden, will be necessary. Clearly, avoidance will be the least costly alternative. However, if avoidance is not possible, then data recovery procedures should be designed to acquire detailed information on site and midden chronology, data on subsistence, and detailed information on midden structure.

In the case of 41BR522, our testing efforts have demonstrated that prehistoric off-midden deposits are minimal. No features were uncovered, and evidence for an outside surface clearly associated with the midden was minimal. Consequently, data recovery efforts should focus on the midden. In the case of 41BR522, we have clear and convincing evidence for a central feature. It is also the case that, at least in those portions of the midden that were tested, deposits are relatively shallow. Given these conditions, one possible mitigation strategy would be to rely primarily on hand-excavated units, with mechanical scraping being limited to a search for outside features and the removal of those portions of the midden not hand-excavated. Figure 10-2 presents one possible scenario that essentially involves the completion of the trench excavated during our testing efforts. Working from the trench face, hand-excavated units would be placed on the southeastern half of the midden. These units would be excavated through the midden deposits and extend to an area beyond the midden. Additional handexcavated units would be placed to the west to complete the excavation of the central feature identified during testing. If this plan were to be adopted, approximately 54 additional hand-excavated units would be placed at this site. After completion of the hand excavation, we suggest that the remaining portion of the midden be removed in a manner similar to that outlined previously for 41BR392. Finally, mechanical scraping of the outside area in an effort to locate any additional features associated with the burned rock midden should be undertaken.

As outlined for 41BR392, the mechanical work and the hand-excavation of contiguous units should produce a variety of different data sets that could be used to investigate midden chronology, construction, and subsistence. These 


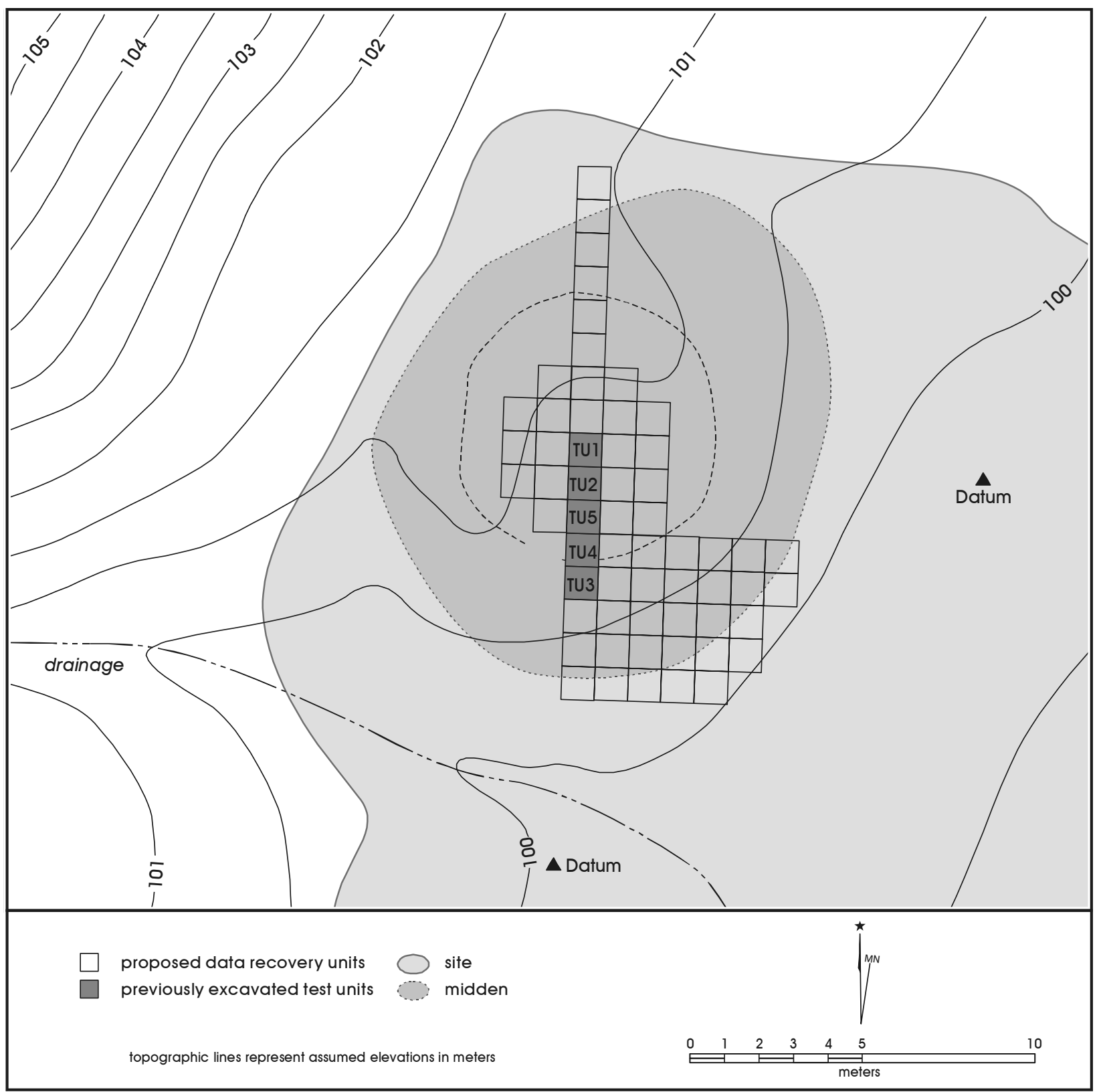

Figure 10-2. Proposed data recovery excavations on 41 BR522. 
include flotation results, direct dating of geophytes, and possible subsistence information from lipid residues. These data sets, combined with information of rock size from contiguous units and potential data such as faunal material and information of subsistence provided by lithic artifacts, should provide critical data for the investigations at this site. We suggest that these procedures would effectively mitigate the prehistoric component at 41BR522.

\section{Report Summary}

CAR conducted eligibility testing on four sites on Camp Bowie, Brown County, Texas, for possible inclusion on the National Register of Historic Places and possible designation as State Archeological Landmarks. An assessment of the integrity of the archaeological deposits, as well as the data potential of these locations with respect to several different research domains was conducted. Two sites, 41BR392 and 41BR522, exhibited good to excellent integrity. In addition, these sites contained a variety of data sets that are directly relevant to understanding the formation, function, and chronology of burned rock middens. As such, these sites are recommended as eligible for inclusion to the NRHP under criterion D. These sites are also recommended for designation as SALs as they are likely to yield information that can contribute to a better understanding of Texas prehistory. Both sites should be avoided during planned training activities within Camp Bowie. If these sites cannot be avoided, then procedures should be designed to mitigate any damage to these significant archaeological deposits. We have suggested some potential data recovery strategies that would collect significant data from these two sites.

The two remaining sites, 41BR471 and 41BR500, both have data of limited or questionable integrity. Site 41BR471 lacks any significant data for assessing either chronological or subsistence concerns. Site 41BR500 has data relevant to chronology, but the integrity of these data sets are questionable. No data directly relevant to subsistence considerations are present. As such, CAR does not recommend these sites for inclusion to the NRHP. In addition, we do not feel that these sites warrant SAL status. No additional investigation is recommended for either of these sites. 



\section{References Cited}

Black, S. L.

1986 The Clemente and Herminia Hinojosa Site, 41JW8: A Toyah Horizon Campsite in Southern Texas. Special Report No. 18. Center for Archaeological Research, The University of Texas at San Antonio.

1989a Central Texas Plateau Prairie. In From the Gulf Coast to the Rio Grande: Human Adaptation in Central, South and Lower Pecos Texas, by T. R. Hester, S. L. Black, D. G. Steele, B. W. Olive, A. A. Fox, K. J. Reinhard, and L. C. Bement, pp. 17-38. Research Series No. 33. Arkansas Archeological Survey, Fayetteville.

1989b South Texas Plains. In From the Gulf Coast to the Rio Grande: Human Adaptation in the Central, South, and Lower Pecos Texas, by T. R. Hester, S. L. Black, D. G. Steele, B. W. Olive, A. A. Fox, K. J. Reinhard, and L. C. Bement, pp. 39-62. Research Series No. 33. Arkansas Archeological Survey, Fayetteville.

1997 Scenarios of Midden Accumulation. In Hot Rock Cooking on the Greater Edwards Plateau: Four Burned Rock Midden Sites in West Central Texas, edited by S. L. Black, L. W. Ellis, D. G. Creel, and G. T. Goode, pp. 140-150. Studies in Archeology 22. Texas Archeological Research Laboratory, The University of Texas at Austin.

Black, S. L., L. W. Ellis, D. G. Creel, and T. G. Goode

1997 Hot Rock Cooking on the Greater Edwards Plateau: Four Burned Rock Midden Sites in West Central Texas. 2 vols. Studies in Archaeology 22, Texas Archaeological Research Laboratory, The University of Texas at Austin; Archaeology Studies Program, Report 2, Environmental Affairs Department, Texas Department of Transportation, Austin.

Black, S. L., and D. G. Creel

1997 The Central Texas Burned Rock Midden Reconsidered. In Hot Rock Cooking on the Greater Edwards Plateau: Four Burned Rock Midden Sites in West Central Texas. 2 vols. Studies in Archaeology 22, Texas Archaeological Research Laboratory, The University of Texas at Austin; Archaeology Studies Program, Report 2, Environmental Affairs Department, Texas Department of Transportation, Austin.

Black, S. L., and A. J. McGraw

1985 The Panther Springs Creek Site: Cultural Change and Continuity in the Upper Salado Creek Drainage, SouthCentral Texas. Archaeological Survey Report, No. 100. Center for Archaeological Research, The University of Texas at San Antonio.

Briggs, A. K.

1992 An Archaeological Survey of Sample Areas within the Proposed Camp Bowie Acquisition Area, near Brownwood, Brown County, Texas. Manuscript on file at the Texas Historical Commission.

Bomar, G. W.

1999 Texas Weather. Second edition, second printing. University of Texas Press, Austin.

Bousman, C. B.

1998 Paleoenvironmental Change in Central Texas: The Palynological Evidence. Plains Anthropologist 43(164): 201-219.

Campbell, T. N.

1952 The Kent-Crane Site: A Shell Midden on the Texas Coast. Bulletin of the Texas Archeological and Paleontological Society 23:39-77. 
Campbell, T. N., and T. J. Campbell

1981 Historic Indians of the Choke Canyon Reservoir and Surrounding Area, Southern Texas. Choke Canyon Series No. 1. Center for Archaeological Research, The University of Texas at San Antonio.

de Castañeda, Pedro, et al.

1990[1933] The Journey of Coronado 1540-1542. Translated by George Parker Winship. Dover Publications, Inc., New York.

Chipman, D. E.

1992 Spanish Texas, 1519-1821. University of Texas Press, Austin.

Clower, D. F.

1980 Soil Survey of Brown and Mills Counties, Texas. United States Department of Agriculture, Soil Conservation Service and the Texas Agricultural Experimental Station.

Collins, M. B.

1991 Thoughts on Future Investigations of Burned Rock Middens. In The Burned Rock Middens of Texas: An Archeological Symposium, edited by T. R. Hester. Studies in Archeology 13. Texas Archeological Research Laboratory, The University of Texas at Austin.

1995 Forty Years of Archeology in Central Texas. Bulletin of the Texas Archeological Society 66:361-400.

Creel, D. G.

1978 An Archeological Survey in the South Concho River Area, West Central Texas. Bulletin of the Texas Archeological Society 49:241-307.

1986 Study of Prehistoric Burned Rock Middens in West Central Texas. Unpublished Ph.D. dissertation. Department of Anthropology, The University of Arizona, Tucson.

1991 Assessing the Relationship Between Burned Rock Midden Distribution and Archaic Subsistence in West Central Texas. In The Burned Rock Middens of Texas: An Archeological Symposium, edited by T. R. Hester, pp. 33-43. Studies in Archeology 13, Texas Archeological Research Laboratory, The University of Texas at Austin.

1997 Analysis of the Distribution of Burned Rock Midden Sites in the Study Area. In Hot Rock Cooking on the Greater Edwards Plateau: Four Burned Rock Midden Sites in West Central Texas, edited by S. L. Black, L. W. Ellis, D. G. Creel, and G. T. Goode, pp. 89-98. Studies in Archeology 22. Texas Archeological Research Laboratory, The University of Texas at Austin; Archeology Studies Program, Report 2, Environmental Affairs Department, Texas Department of Transportation, Austin.

Davis, W. B.

1974 The Mammals of Texas. Bulletin 41. Texas Parks and Wildlife Department, Austin, Texas.

Dearing, J.

1999 Environmental Magnetic Susceptibility. Chi Publishing, Kenilworth, England.

Decker, S.

1997 Appendix A: Provenience Tables. In Hot Rock Cooking on the Greater Edwards Plateau: Four Burned Rock Midden Sites in West Central Texas, Volume 2, by S. L. Black, L. W. Ellis, D. G. Creel, and G. T. Goode, pp. 341392. Studies in Archeology 22. Texas Archeological Research Laboratory, The University of Texas at Austin; Archeology Studies Program, Report 2, Environmental Affairs Department, Texas Department of Transportation, Austin. 
Dering, J. P.

1997 Formation Processes and the Plant Economy at Burned Rock Middens: The View from a Rockshelter. Manuscript on file, Center for Environmental Archaeology, Texas A\&M University, College Station.

1999 Earth Oven Processing in Archaic Period Economics: An Example from a Semi-Arid Savannah in South-Central North America. American Antiquity 64(4):659-674.

2003 Appendix C: Botanical Perspectives on Land Use in the Cross Timbers and Prairies. In Archaeological Testing to Determine the National Register Eligibility Status of 18 Prehistoric Sites on Camp Bowie, Brown County, Texas, volume 2, by R. P. Mauldin, D. L. Nickels, and C. J. Broehm, pp. 58-78. Archaeological Survey Report, No. 334. Center for Archaeological Research, The University of Texas at San Antonio.

Dillehay, T.

1974 Late Quaternary Bison Population Changes on the Southern Plains. Plains Anthropologist 19(64):180-196.

Ensor, H. B., J. W. Saunders, C. S. Mueller-Wille, S. Carlson, R. Korgel, F. Winchel, and L. Wootan-Ellis

1992 Analysis of Material Culture. In An Archaeological Survey of the Proposed South Bend Reservoir Area: Young, Stephens and Throckmorton Counties, Texas. edited by J. W. Saunders, C. S. Meuller-Wille and D. L. Carlson. Archaeological Surveys No. 6. Archaeological Research Laboratory, Texas A\&M University, College Station.

Environmental Assessment, Camp Bowie

1992 Environmental Assessment, Camp Bowie Land Acquisition. Manuscript on file at the Adjutant General's Department of Texas, Environmental Branch, Austin.

Everitt, B. S.

1977 The Analysis of Contingency Tables. Chapman and Hall, London.

Fenneman, N.

1931 Physiography of the Western united States. McGraw Hill, New York.

Fox, A. A., and D. E. Fox

1967 The Classen Rockshelter, 41BX23. Manuscript on file. Center for Archaeological Research, The University of Texas at San Antonio.

Gearhart, B., and M. W. Voellinger

1986 Archaeological Testing on Sites 41BR313 and 41BR314, Brown County, Texas. Manuscript on file, Texas Historical Commission, Austin, Texas.

Givens, R. D.

1968 A Preliminary Report on Excavations at Hitzfelder Cave. Bulletin of the Texas Archeological Society 38:47-50.

Goode, G. T.

1991 Late Prehistoric Burned Rock Middens in Central Texas. In The Burned Rock Middens of Texas: An Archaeological Symposium, edited by T. R. Hester, pp. 71-93. Studies in Archeology 13. Texas Archeological Research Laboratory, The University of Texas at Austin.

Gose, W. A., and D. L. Nickels

2001 Archaeomagnetic and Magnetic Susceptibility Analyses. In Test Excavations at the Culebra Creek Site, 41BX126, Bexar County, Texas, by D. L. Nickels, C. B. Bousman, J. D. Leach, and D. A. Cargill, pp. 204-214. Archaeological Survey Report, No. 265, Center for Archaeological Research, The University of Texas at San Antonio. Archeology Studies Program, Report 3, Environmental Affairs Division, Texas Department of Transportation, Austin. 
Gould, F. W.

1975 Texas Plants, A Checklist and Ecological Summary. Texas A\&M University, College Station.

Greaves, R. D.

2002 Archaeological Survey of Three Land Parcels and Shovel Testing of Four Sites at Camp Bowie, Brown County, Texas. Archaeological Survey Report, No. 328. Center for Archaeological Research, The University of Texas at San Antonio.

Gunn, J., and R. Mahula

1977 Hop Hill: Culture and Climate Change in Central Texas. Special Report No 5. Center for Archaeological Research, The University of Texas at San Antonio.

Haberman, S. J.

1973 The Analysis of Residuals in Cross-classified Tables. Biometrics 29:205-220.

Hall, G. D.

1981 Allens Creek: A Study in the Cultural Prehistory of the Brazos River Valley, Texas. Research Report 61. Texas Archeological Survey, The University of Texas at Austin.

Hester, T. R.

1973 The Formation of a Burned Rock Midden: A California Example. The Record 30(1):4. Dallas Archeological Society, Dallas, Texas.

1991 The Burned Rock Middens of Texas: An Archaeological Symposium. Studies in Archeology 13. Texas Archeological Research Laboratory, The University of Texas at Austin.

1995 The Prehistory of South Texas. Bulletin of the Texas Archeological Society 66:427-459.

Highley, L., C. Graves, and G. Judson

1978 Archeological Investigations at Scorpion Cave (41ME7), Medina County, Texas. Bulletin of the Texas Archeological Society 49:139-194.

Hofman, J. L.

1989 Prehistoric Culture History-Hunters and Gatherers in the Southern Great Plain. In From Clovis to Comanchero: Archeological Overview of the Southern Great Plains, by J. L. Hofman, R. L. Brooks, J. S. Hays, D. W. Owsley, R. L. Jantz, M. K. Marks, and M. H. Manhein, pp. 25-60. Research Series No. 35. Arkansas Archeological Survey, Fayetteville.

Howard, M. A.

1991 Burned Rock Midden Excavations, Hearths and Botanical Remains. In The Burned Rock Middens of Texas: An Archeological Symposium, edited by T. R. Hester. Studies in Archeology 13. Texas Archeological Research Laboratory, The University of Texas at Austin.

Houk, B. A., and J. C. Lohse

1993 Archeological Investigations at the Mingo Site, Bandera County, Texas. Bulletin of the Texas Archeological Society 61:193-247.

Huebner, J. A.

1991 Late Prehistoric Bison Populations in Central and Southern Texas. Plains Anthropologist 36(137):343-358. 
Hurt, R. D.

1980 Archeological Investigations of Portions of the Middle Concho Valley. Unpublished Masters thesis, Texas Tech University, Lubbock.

Huskey, V.

1935 An Archaeological Survey of the Nueces Canyon of Texas. Bulletin of the Texas Archeological and Paleontological Society 7:104-114.

Jackman, J. A.

1997 A Field Guide to Spiders and Scorpions of Texas. Texas Monthly Field Guide Series. Gulf Publishing Co., Houston Texas.

Johnson, L.

1995 Past Cultures and Climates at Jonas Terrace, 41ME29, Medina County, Texas. Office of the State Archeologist, Report 40. Texas Department of Transportation and Texas Historical Commission, Austin.

Johnson, L., and G. T. Goode

1994 A New Try at Dating and Characterizing Holocene Climates, as well as Archeological Period, on the Eastern Edwards Plateau. Bulletin of the Texas Archeological Society 65:5-51.

Johnson, L., and V. T. Holliday

1986 The Archaic Record at Lubbock Lake. In Current Trends in Southern Plains Archaeology, edited by T. G. Baugh. Plains Anthropologist Memoir 22:7-54.

Kegley, G. P., and A. Black

1978 An Archaeological Survey of Cordell and Camp Bowie City Park Sites, Brownwood, Texas. Texas Antiquities Committee, Austin, Texas.

Kelley, J. C.

1947 The Cultural Affiliations and Chronological Position of the Clear Fork Focus. American Antiquity 13:97-109.

Kelley, J. C., and T. N. Campbell

1942 What are the burnt rock mounds of Texas? American Antiquity 7:319-322.

Kirby, F. E., and R. Moir

1976 Brownwood Dam Modifications and Archaeological Assessment. Reports in Archaeology No. 95. Archaeology Research Program, Southern Methodist University, Dallas, Texas.

Leach, J. D., and C. B. Bousman

2001 Cultural and Secondary Formation Processes: On the Dynamic Accumulation of Burned Rock Middens. In Test Excavations at the Culebra Creek Site, 41BX126, Bexar County, Texas, by D. L. Nickels, C. B. Bousman, J. D. Leach, and D. A. Cargill, pp. 119-145. Archaeological Survey Report, No. 265, Center for Archaeological Research, The University of Texas at San Antonio; Archeology Studies Program, Report 3, Environmental Affairs Division, Texas Department of Transportation, Austin.

Leffler, J. J.

2002 Ranchers, Farmers, Soldiers, and the CCC: The Background for Seven Historical Sites at Camp Bowie, Brown County, Texas. Archaeological Survey Report, No. 325. Center for Archaeological Research, The University of Texas at San Antonio. 
Lukowski, P. D.

1987 Archaeological Investigations along the Leona River Watershed, Uvalde County, Texas. Archaeological Survey Report, No. 132. Center for Archaeological Research, The University of Texas at San Antonio.

1988 Archaeological Investigations at 41BX1, Bexar County, Texas. Archaeological Survey Report, No. 135. Center for Archaeological Research, The University of Texas at San Antonio

McClean, R. G., and W. F. Kean

1993 Contributions of Wood Ash Magnetism to Archeomagnetic Properties of Fire Pits and Hearths. Earth and Planetary Science Letters 119:387-394.

Mahoney, R. B., H. J. Shafer, S. A. Tomka, L. C. Nordt, and R. P. Mauldin

2003 Royal Coachman (41CM111): An Early Middle Archaic Site along Cordova Creek in Comal County, Texas. Archaeological Survey Report, No. 332, Center for Archaeological Research, The University of Texas at San Antonio. Archeological Studies Program, Report No. 49, Environmental Affairs Division, Texas Department of Transportation, Austin.

Mahoney, R. B., R. P. Mauldin, and S. A. Tomka

2002 Archeological Data Recovery Excavations along Becerra Creek (41WB556), Webb County, Texas. Archaeological Survey Report, No. 321, Center for Archaeological Research, The University of Texas at San Antonio; Archeology Studies Program, Report No. 44, Environmental Affairs Division, Texas Department of Transportation, Austin.

Malainey, M. E.

1997 The Reconstruction and Testing of Subsistence and Settlement Strategies for the Plains, Parkland and Southern Boreal Forest. Unpublished Ph.D. thesis, University of Manitoba.

Mauldin, R. P.

1995 Groping for the Past: Investigating Archaeological Patterns Across Space and Time in the Southern Southwestern United States. Unpublished Ph.D. dissertation, Department of Anthropology, The University of New Mexico, Albuquerque.

2003 Chapter 8: Development of Burned Rock Middens at Camp Bowie. In Archaeological Testing to Determine the National Register Eligibility Status of 18 Prehistoric Sites on Camp Bowie, Brown County, Texas, volume 1, by R. P. Mauldin, D. L. Nickels, and C. J. Broehm, pp. 175-196. Archaeological Survey Report, No. 334. Center for Archaeological Research, The University of Texas at San Antonio.

Mauldin, R. P., and C. J. Broehm

2001 An Archaeological Survey of Camp Bowie, Brown County, Texas. Archaeological Survey Report, No. 319. Center for Archaeological Research, The University of Texas at San Antonio.

Mauldin, R. P., and D. L Nickels

2001 Chapter 2: An Overview of the Twin Buttes Archaeological Project. In An Archaeological Survey of Twin Buttes Reservoir, Tom Green County, Texas, by R. P. Mauldin and D. L. Nickels, pp. 5-24. Archaeological Survey Report, No. 300. Center for Archaeological Research, The University of Texas at San Antonio.

2003 Chapter 7: Chronological Placement of Camp Bowie Burned Rock Middens. In Archaeological Testing to Determine the National Register Eligibility Status of 18 Prehistoric Sites on Camp Bowie, Brown County, Texas, volume 1, by R. P. Mauldin, D. L. Nickels, and C. J. Broehm, pp. 58-78 Archaeological Survey Report, No. 334. Center for Archaeological Research, The University of Texas at San Antonio. 
Mauldin, R. P., D. L. Nickels, and C. J. Broehm

2003 Archaeological Testing to Determine the National Register Eligibility Status of 18 Prehistoric Sites on Camp Bowie, Brown County, Texas. 2 volumes. Archaeological Survey Report, No. 334. Center for Archaeological Research, The University of Texas at San Antonio.

Meissner, B. A.

1993 Where the Buffalo Roam: Archaeological Evidence of Bison Populations in South Central Texas. Manuscript on file, Center for Archaeological Research, The University of Texas at San Antonio.

Munsey, C.

1970 The Illustrated Guide to Collecting Bottles. Hawthorn Books, Inc., New York

Nance, H. S., and E. G. Wermund

1993 Geological and Climatic Survey: Camp Bowie Military Reservation, Brownwood, Texas. Bureau of Economic Geology, The University of Texas at Austin.

Nature Conservancy of Texas

1996 Land Cover Analysis of Texas Army National Guard Training Sites. Report Submitted to the Texas Adjutant General's Department.

Neck, R. W.

1997 Appendix F: Freshwater Mussel Remains and Snail Shell from Four Burned Rock Midden Sites in Central Texas. In Hot Rock Cooking on the Greater Edwards Plateau: Four Burned Rock Midden Sites in West Central Texas, Volume 2, by S. L. Black, L. W. Ellis, D. G. Creel, and G. T. Goode, pp. 629-640. Studies in Archeology 22, Texas Archeological Research Laboratory, The University of Texas at Austin; Archeology Studies Program, Report 2, Environmental Affairs Department, Texas Department of Transportation, Austin.

Nickels, D. L., C. B. Bousman, J. D. Leach, and D. A. Cargill

2001 Test Excavations at the Culebra Creek Site, 41BX126, Bexar County, Texas. Archaeological Survey Report No. 265, Center for Archaeological Research, The University of Texas at San Antonio; Archeology Studies Program, Report 3, Environmental Affairs Division, Texas Department of Transportation, Austin.

Patterson, L. W.

1988 Intergroup Conflict in Prehistoric Texas. Houston Archeological Society Journal 90:8-10.

Pearce, J. E.

1919 Indian Mounds and Other Relics of Indian Life in Texas. American Anthropologist 21:223-234.

1932 The Present Status of Texas Archeology. Bulletin of the Texas Archeological and Paleontological Society 4: $44-54$.

Polak, M.

2000 Bottles: Identification and Price Guide. Harper Collins Publishers, New York.

Prewitt, E. R.

1974 Archeological Investigations at the Loeve-Fox Site, Williams County, Texas. Research Report 49. Texas Archeological Survey, The University of Texas at Austin.

1981 Culture Chronology in Central Texas. Bulletin of the Texas Archeological Society 52:65-89.

1985 From Circleville to Toyah: Comments on Central Texas Chronology. Bulletin of the Texas Archeological Society 54:201-238. 
1991 Burned Rock Middens: A Summary of Previous Investigations and Interpretations. In The Burned Rock Middens of Texas: An Archaeological Symposium, edited by T. R. Hester. Studies in Archeology 13. Texas Archeological Research Laboratory, The University of Texas at Austin.

Prikryl, D. J.

1983 An Archaeological Survey of the City of Brownwood Proposed Sanitary Landfill Site, Brown County, Texas. Prewitt and Associates, Austin, Texas.

Quigg, J. M.

1999 The Lino Site: A Stratified Late Archaic Campsite in a Terrace of the San Idelfonzo Creek, Webb County, Southern Texas. Technical Report No. 23765, TRC Mariah Associates Inc., Austin.

Ramsey, C. B.

2000 OxCal Program Version 3.5. Radiocarbon Accelerator Unit, University of Oxford. Oxford, U.K.

Reynolds, R. L., and J. W. King

1995 Magnetic Records of Climate Change. U.S. National Report to I.U.G.G., 1991-1994. American Geophysical Union. <http://www.agu.ong/revgeophys/reyno100/reyno100.html> Accessed April 2001.

Robbins, C. S., B. Bruun, and A. S. Zim

1983 A Guide to Field Identification, Birds of North America. Golden Books, New York.

Robinson, D. G., T. M. Meade, L. Haslouer Kay, L. Gassaway, and D. Kay

2001 An Archaeological Inventory of Camp Swift, Bastrop County, Texas. Archaeological Survey Report, No. 316. Center for Archaeological Research, The University of Texas at San Antonio.

Shafer, H. J., E. P. Baxter, and P. Dering

1975a Upper Pecan Bayou Watershed, Brown County, Texas: An Archaeological Survey of Structure No. 30. Texas A\&M Research Facility, College Station.

1975b Brownwood Laterals Watershed, Brown County Texas: Archaeological Surveys of Floodwater Retarding Structures 1, Z24, 5, 18, 24 and 2. Report No. 13, Anthropology Laboratory, Texas A\&M University, College Station.

Singer, M. J., and P. Fine

1989 Pedogenic Factors Affecting Magnetic Susceptibility of Northern California Soils. Soil Science of America Journal 53:1119-1127.

Skelton, D. W.

1977 Archeological Investigations at the Fayette Power Project, Fayette County, Texas. Research Report 60. Texas Archeological Survey, The University of Texas at Austin.

Skinner, S. A.

1981 Aboriginal Demographic Changes in Central Texas. Plains Anthropologist 26(92):111-118.

Steele, D. G., and C. Assad Hunter

1986 Analysis of Vertebrate Faunal Remains from 41MC222 and 41MC296, McMullen County, Texas. In The Prehistoric Sites at Choke Canyon Reservoir, Southern Texas: Results of Phase II Archaeological Investigations, edited by G. D. Hall, T. R. Hester, and S. L. Black. Choke Canyon Series, No. 10. Center for Archaeological Research, The University of Texas at San Antonio. 
Story, D. A.

1985 Adaptive Strategies of Archaic Cultures of the West Gulf Coastal Plain. In Prehistoric Food Production in North America, edited by R. I. Ford, pp. 19-56. Anthropological Papers No. 75. Museum of Anthropology, University of Michigan, Ann Arbor.

Suhm, D. A., A. D. Krieger, and E. B. Jelks

1954 An Introductory Handbook of Texas Archeology. Bulletin of the Texas Archeological Society 25.

Swanson, E. R.

1995 Geo-Texas. A Guide to Earth Sciences. Texas A\&M University Press, College Station.

Taylor, A. J., and C. L. Highley

1995 Archaeological Investigations at the Loma Sandia Site (41LK28): A Prehistoric Campsite in Live Oak County, Texas, 2 volumes. Studies in Archeology No. 20. Texas Archeological Research Laboratory, The University of Texas at Austin.

Texas Parks and Wildlife (TPW)

1994 Biological Inventory of Camp Bowie. Prepared for the Texas Army National Guard by the Texas Heritage Program Resource Protection Division of the Texas Parks and Wildlife Department, Austin.

Thoms, A. V.

1989 The Northern Roots of Hunter-Gatherer Intensification: Camas and the Pacific Northwest. Unpublished Ph.D. dissertation. Washington State University, Pullman.

Tomka, S. A.

2002 Hunter-Gatherer Technological Organization during the Archaic in South Texas. Paper presented at the 73rd Annual Meeting of the Texas Archeological Society, Laredo.

Treece, A. C.

1993 Chapter 9: Summary and Conclusions. In Cultural Resource Investigations in the O. H. Ivie Reservoir, Concho, Colman, and Runnels Counties, Texas. Volume III: Data Recovery Results from Non-Ceramic Sites, by A. C. Treece, C. Lintz, W. N. Trierweiler, J. M. Quigg, and K. A. Miller, pp. 477-598. Technical Report No. 346-III. Mariah Associates, Austin, Texas.

Turner, S. E.

1989 Exploring the Possibilities of Acorn Utilization in the Burned Rock Middens of Texas. Bulletin of the Texas Archeological Society 59:177-191.

Turner, S. E., and T. R. Hester

1999 A Field Guide to Stone Artifacts of Texas Indians. Third edition. Gulf Publishing, Houston.

Wandsnider, L.

1997 The Roasted and the Boiled: Food Composition and Heat Treatment with Special Emphasis on Pit-Hearth Cooking. Journal of Anthropological Archaeology 16:1-48.

Waters, M. R.

1992 Principles of Geoarchaeology: A North American Perspective. University of Arizona Press, Tuscon. 
Weir, F. A.

1976 The Central Texas Archaic. Unpublished PhD Dissertation. Anthropology Department, Washington State University.

Wells, T.

1998 Nail Chronology: The use of Technologically Derived Features. Historical Archaeology 32(2):78-99.

Wilson, E. W.

1930 Burned Rock Mounds of Southwest Texas. Bulletin of the Texas Archeological and Paleontological Society 2:59-63.

Wormser, A. J., and S. Sullo-Prewitt.

2001 Cultural Resources Inventory of Camp Bowie, Brownwood, Texas. Archaeological Survey Report No. 317, Center for Archaeological Research, The University of Texas at San Antonio.

Wormser, A. J., G. P. Davis, and C. Leshley

1994 Archaeological Investigation of Proposed Camp Bowie Firebreak, Brown County, Texas. The Adjutant General's Department of Texas. Manuscript on file, Texas Historical Commission, Austin, Texas

Wormser, A. J., D. M. Sullo, and S. C. Stringer

1997 Archaeological Investigations of the Proposed Tank Training Area at Camp Bowie, Brown County, Texas. The Adjutant General's Department of Texas. Manuscript on file, Texas Historical Commission, Austin, Texas. 
Appendix A

Radiocarbon Dating Results 


\begin{tabular}{|c|c|c|c|}
\hline Sample Data & $\begin{array}{l}\text { Measured } \\
\text { Radiocarbon Age }\end{array}$ & $\begin{array}{c}13 \mathrm{C} / 12 \mathrm{C} \\
\text { Ratio }\end{array}$ & $\begin{array}{c}\text { Conventional } \\
\left.\text { Radiocarbon Age( }{ }^{*}\right)\end{array}$ \\
\hline $\begin{array}{l}\text { Beta - } 173024 \\
\text { SAMPLE : TU3-5-392 } \\
\text { ANALYSIS : AMS-Standard deliven } \\
\text { MATERIAL/PRETREATMENT : }(c \\
2 \text { SIGMA CALIBRATION : }\end{array}$ & $\begin{array}{l}\qquad 1120+/-50 \mathrm{BP} \\
\text { ry } \\
\text { (charred material): acid/alkali/acid } \\
\text { Cal AD } 790 \text { to } 1020 \text { (Cal BP } 1160 \text { to } 930)\end{array}$ & $-25.7 \mathrm{o} / \mathrm{oo}$ & $1110+/-50 \mathrm{BP}$ \\
\hline $\begin{array}{l}\text { Beta - } 173025 \\
\text { SAMPLE : TU3-8-392 } \\
\text { ANALYSIS : AMS-Standard deliver } \\
\text { MATERIAL/PRETREATMENT : }( \\
2 \text { SIGMA CALIBRATION : }\end{array}$ & $\begin{array}{l}\qquad 1200+/-40 \mathrm{BP} \\
\text { ry } \\
\text { (charred material): acid/alkali/acid } \\
\text { Cal AD } 770 \text { to } 970(\mathrm{Cal} \mathrm{BP} 1180 \text { to } 980)\end{array}$ & $-26.0 \mathrm{o} / \mathrm{oo}$ & $1180+/-40 \mathrm{BP}$ \\
\hline $\begin{array}{l}\text { Beta - } 173026 \\
\text { SAMPLE : TU3-10-392 } \\
\text { ANALYSIS : AMS-Standard deliven } \\
\text { MATERIAL/PRETREATMENT : }(\mathrm{C} \\
2 \text { SIGMA CALIBRATION : }\end{array}$ & $\begin{array}{l}\qquad 1090+/-50 \mathrm{BP} \\
\text { ry } \\
\text { (charred material): acid/alkali/acid } \\
\text { Cal AD } 770 \text { to } 1000 \text { (Cal BP } 1180 \text { to } 950 \text { ) }\end{array}$ & $-21.2 \mathrm{o} / \mathrm{oo}$ & $1150+/-50 \mathrm{BP}$ \\
\hline $\begin{array}{l}\text { Beta - } 173027 \\
\text { SAMPLE : TU4-5-500 } \\
\text { ANALYSIS : AMS-Standard deliver } \\
\text { MATERIAL/PRETREATMENT : }(\mathrm{C} \\
2 \text { SIGMA CALIBRATION : }\end{array}$ & $\begin{array}{l}\qquad 1250+/-40 \mathrm{BP} \\
\text { ry } \\
\text { (charred material): acid/alkali/acid } \\
\text { Cal AD } 690 \text { to } 900(\mathrm{Cal} \text { BP } 1260 \text { to } 1060)\end{array}$ & $-26.8 \mathrm{o} / 00$ & $1220+/-40 \mathrm{BP}$ \\
\hline $\begin{array}{l}\text { Beta - } 173028 \\
\text { SAMPLE : TU4-4-522 } \\
\text { ANALYSIS : AMS-Standard deliven } \\
\text { MATERIAL/PRETREATMENT : } \\
2 \text { SIGMA CALIBRATION : }\end{array}$ & $\begin{array}{l}\qquad 820+/-40 \mathrm{BP} \\
\text { ry } \\
\text { (charred material): acid/alkali/acid } \\
\text { Cal AD } 1170 \text { to } 1280(\mathrm{Cal} \text { BP } 780 \text { to } 670)\end{array}$ & $-25.5 \mathrm{o} / \mathrm{oo}$ & $810+/-40 \mathrm{BP}$ \\
\hline $\begin{array}{l}\text { Beta - } 173029 \\
\text { SAMPLE : TU4-5-522 } \\
\text { ANALYSIS : AMS-Standard deliver } \\
\text { MATERIAL/PRETREATMENT : } \\
2 \text { SIGMA CALIBRATION : }\end{array}$ & $\begin{array}{l}\qquad 760+/-40 \mathrm{BP} \\
\text { ry } \\
\text { (charred material): acid/alkali/acid } \\
\text { Cal AD } 1220 \text { to } 1300(\mathrm{Cal} \mathrm{BP} 730 \text { to } 650)\end{array}$ & $-25.8 \mathrm{o} / 00$ & $750+/-40 \mathrm{BP}$ \\
\hline
\end{tabular}




\section{CALIBRATION OF RADIOCARBON AGE TO CALENDAR YEARS}

\section{(Variables: C $13 / \mathrm{C} 12=-25.7:$ lab. $\mathrm{mult}=1$ )}

Laboratory number: Beta-173024

Conventional radiocarbon age: $1110 \pm 50 \mathrm{BP}$

2 Sigm a calibrated result: Cal AD 790 to 1020 (Cal BP 1160 to 930)

$(95 \%$ p robability)

Intercept data

Intercept of radiocarbon age with calibration curve:

Cal AD 960 (Cal BP 990)

1 Sigma calibrated result: (68\% probability)

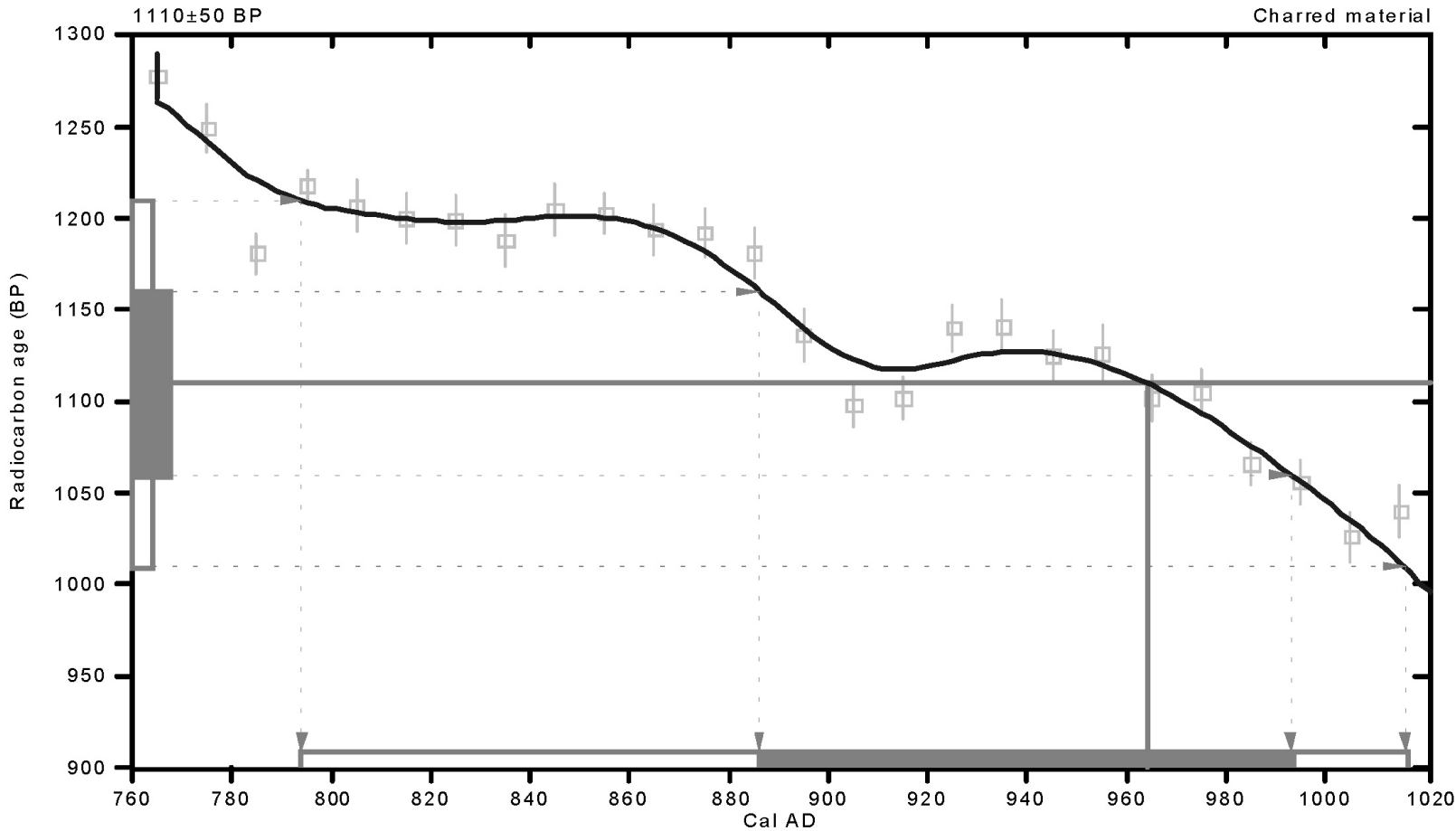

References:

Database used

Calibration Database

Editorial Com ment

Stuiver, M., van der Plicht, $H ., 1998$, Radiocarbon 40(3), pxil-xiii

INTCAL98 Radiocarbon Age Calibration

Stuiver, M., et. al., 1998, Radiocarbon $40(3)$, p1041-1083

$M$ ath ematics

A Simplified Approach to Calibrating C14 Dates

Talma, A.S., Vogel, J. C., 1993, Radiocarbon 35(2), p317-322

Beta Analytic Inc.

4985 SW 74 Court, Miami, Florida 33155 USA Tel: (305)6675167•Fax:(305)6630964 -E-Mail: beta@radiocarbon.com 


\section{CALIBRATION OF RADIOCARBON AGE TO CALENDAR YEARS}

(Variables: C 13/C 12=-26:lab. mult=1)

Laboratory number: Beta-173025

Conventional radiocarbon age: $1180 \pm 40$ BP

2 Sigm a calibrated result: Cal AD 770 to 970 (Cal B P 1180 to 980)

$(95 \%$ p robability)

Intercept data

Intercept of radiocarbon age with calibration curve:

1 Sigma calibrated result: Cal AD 790 to 900 (Cal B P 1160 to 1060 ) (68\% probability)

\section{Cal AD $880($ Cal B P 1070$)$}

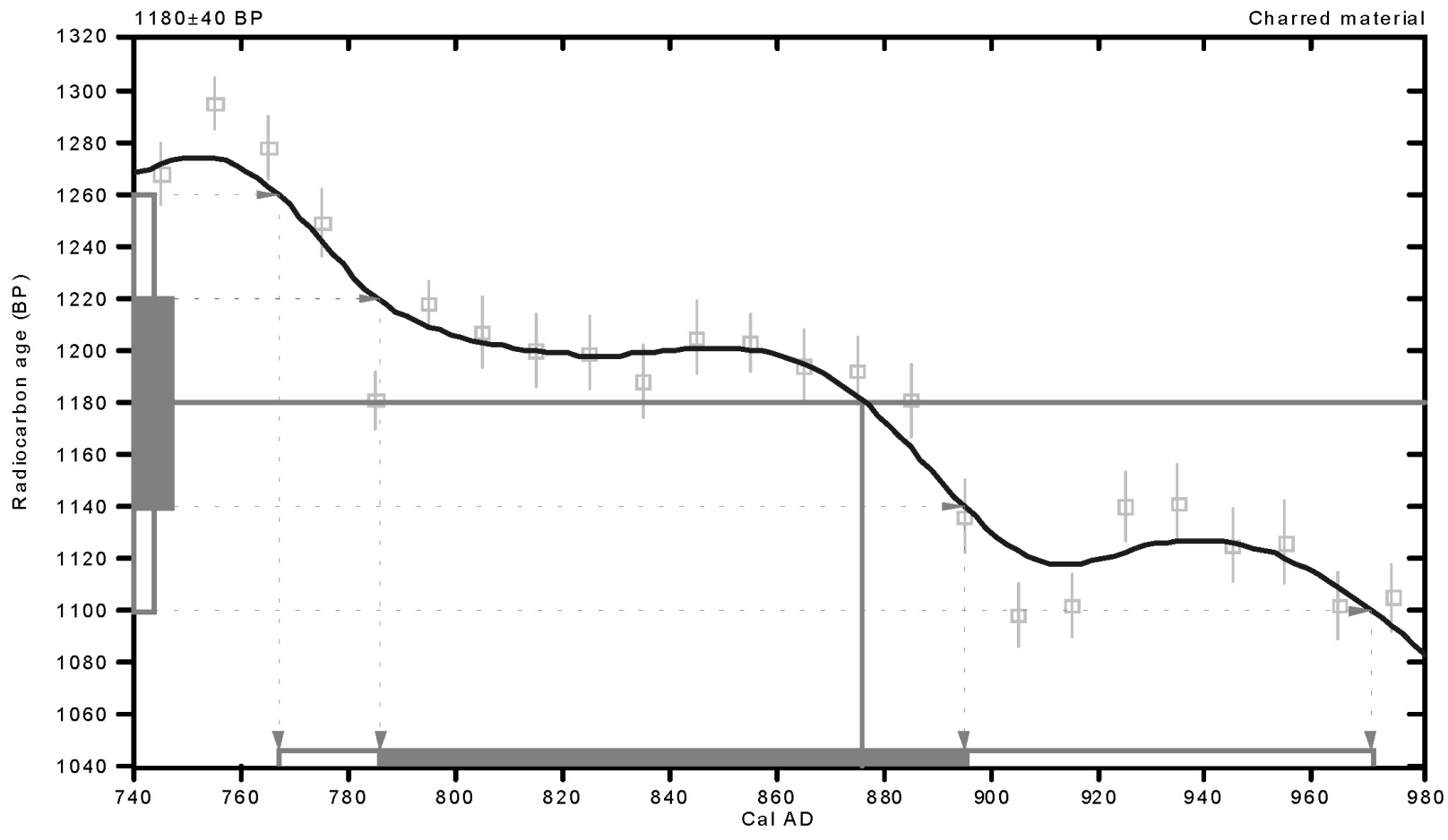

References:

Database used

Calibration Database

Editorial Com ment

Stuiver, M., van der Plicht, H., 1998, Radiocarbon 40(3), pxii-xiii

IN TCAL98 Radiocarbon Age Calibration

Stuiver, M., et. al., 1998, Radiocarbon 40(3), p1041-1083

Math ematics

A Simplified Approach to Calib rating C14 Dates

Talma, A.S., Vogel, J. C., 1993, Radiocarbon 35(2), p317-322

\section{Beta Analytic Inc.}

4985 SW 74 Court, Miami, Florida 33155 USA Tel: (305)6675167• Fax:(305)6630964・E-Mail: beta@radiocarbon.com 


\section{CALIBRATION OF RADIOCARBON AGE TO CALENDAR YEARS}

$$
\text { (Variables: C } 13 / \mathrm{C} 12=-21.2: \text { lab. } \mathrm{mult}=1 \text { ) }
$$

Laboratory number: Beta-173026

Conventional radiocarbon age: $1150 \pm 50 \mathrm{BP}$

2 Sigm a calibrated result: Cal AD 770 to 1000 (Cal BP 1180 to 950)

$(95 \%$ probability)

Intercept data

Intercept of radiocarbon age with calibration curve:

1 Sigma calibrated results: Cal AD 810 to 840 (Cal B P 1140 to 1110 ) and (68\% probability) Cal A D 860 to 970 (Cal B P 1100 to 980 )

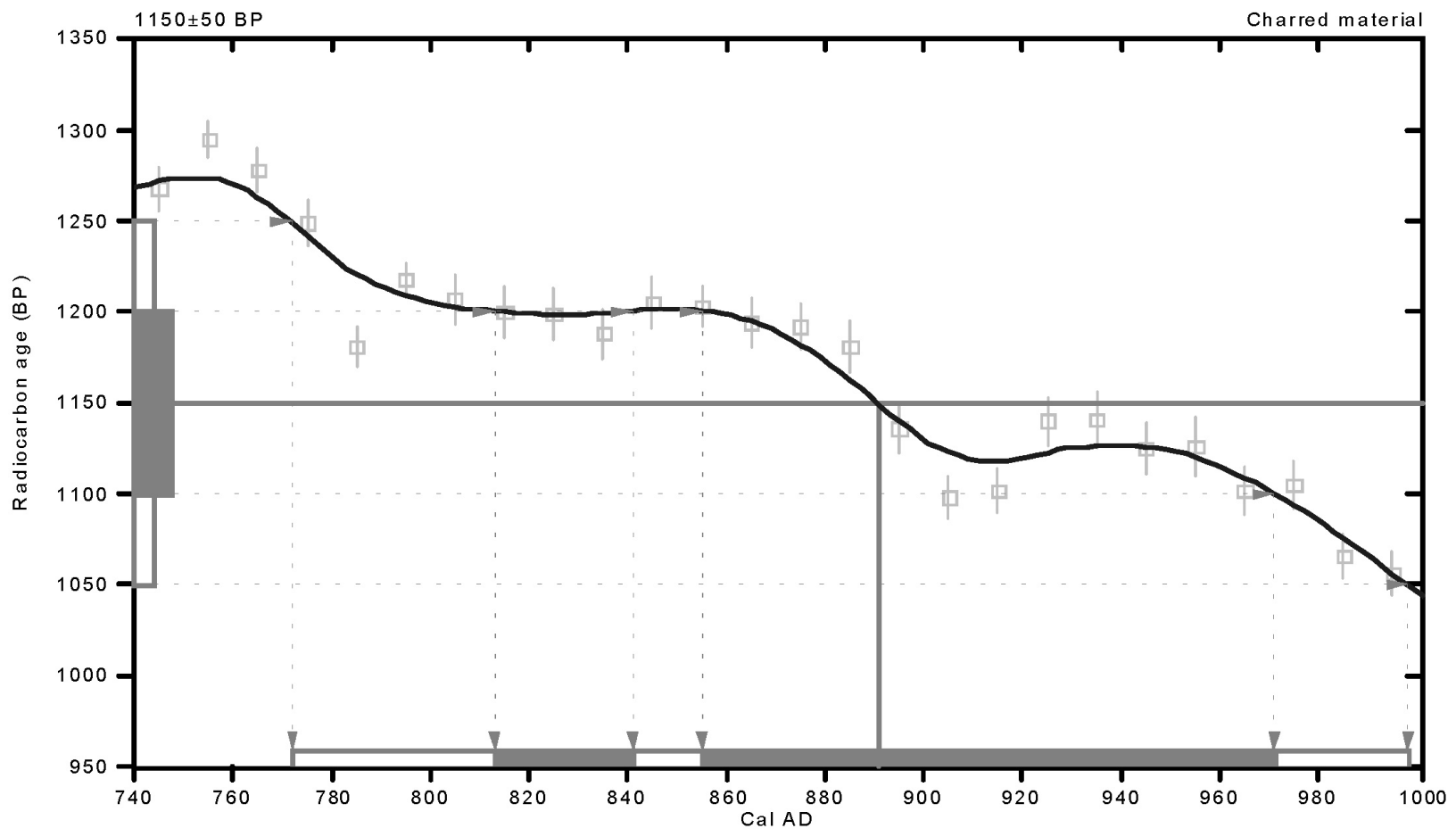

References:

Database used

Calibration Database

Editorial Com ment

Stuiver, M., van der Plicht, H., 1998, Radiocarbon 40(3), pxii-xiii

INTCAL 98 Radiocarbon Age Calibration

Stuiver, M., et. al., 1998, Radiocarbon 40(3), p1041-1083

Math ematics

A Simplified Approach to Calibrating C14 Dates

Talma, A. S., Vogel, J. C., 1993, Radiocarbon 35(2), p317-322

\section{Beta Analy tic Inc.}

4985 SW 74 Court, Miami, Florida 33155 USA Tel: (305) 6675167• Fax:(305)6630964・E-Mail: beta@ radiocarbon.com 


\section{CALIBRATION OF RADIOCARBON AGE TO CALENDAR YEARS}

(Variables: C $13 / \mathrm{C} 12=-26.8: 1 \mathrm{ab} . \mathrm{mult}=1$ )

Laboratory number: Beta-173027

Conventional radiocarbon age: $1220 \pm 40 B P$

2 Sigm a calibrated result: Cal AD 690 to 900 (Cal B P 1260 to 1060)

$(95 \%$ probability)

Intercept data

Intercept of radiocarbon age with calibration curve:

1 Sigma calibrated result: Cal A D 770 to 880 (Cal B P 1180 to 1070 ) $(68 \%$ probability)

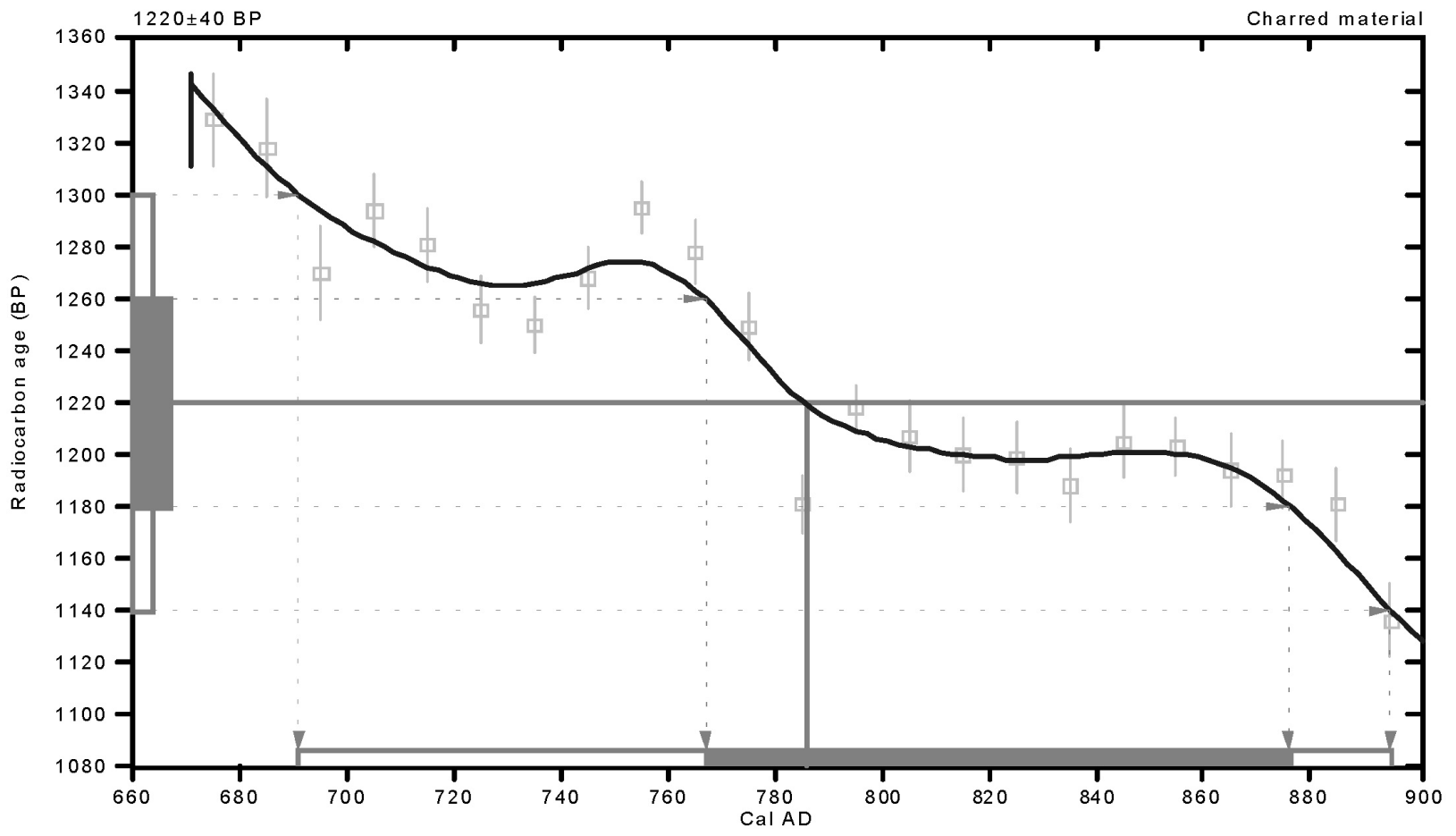

References:

Database used

Calibration Database

Editorial Com ment

Stuiver, M., van der Plicht, H., 1998, Radiocarbon 40(3), pxii-xiii

IN TCA L98 Radiocarbon Age Calibration

Stuiver, M., et. al., 1998, Radiocarbon 40(3), p1041-1083

$M$ ath ematics

A Simplified Approach to Calibrating C 14 Dates

Talma, A.S., Vogel, J. C., 1993 , Radiocarbon 35(2), p317-322

\section{Beta Analy tic Inc.}

4985 SW 74 Court, Miami, Florida 33155 USA Tel: (305)6675167•Fax:(305)6630964・E-Mail:beta@radiocarbon.com 


\section{CALIBRATION OF RADIOCARBON AGE TO CALENDAR YEARS}

$$
\text { (Variables: C } 13 / \mathrm{C} 12=-25.5: \mathrm{lab} . \mathrm{mult}=1 \text { ) }
$$

Labo ratory number: Beta-173028

Conventional radiocarbon age: $810 \pm 40 B P$

2 Sigm a calibrated result: Cal AD 1170 to 1280 (Cal BP 780 to 670 )

$(95 \%$ probability)

Intercept data

Intercept of radiocarbon age

with calibration curve:

1 Sigma calibrated result: Cal A D 1200 to 1270 (Cal B P 750 to 680 )

(68\% probability)

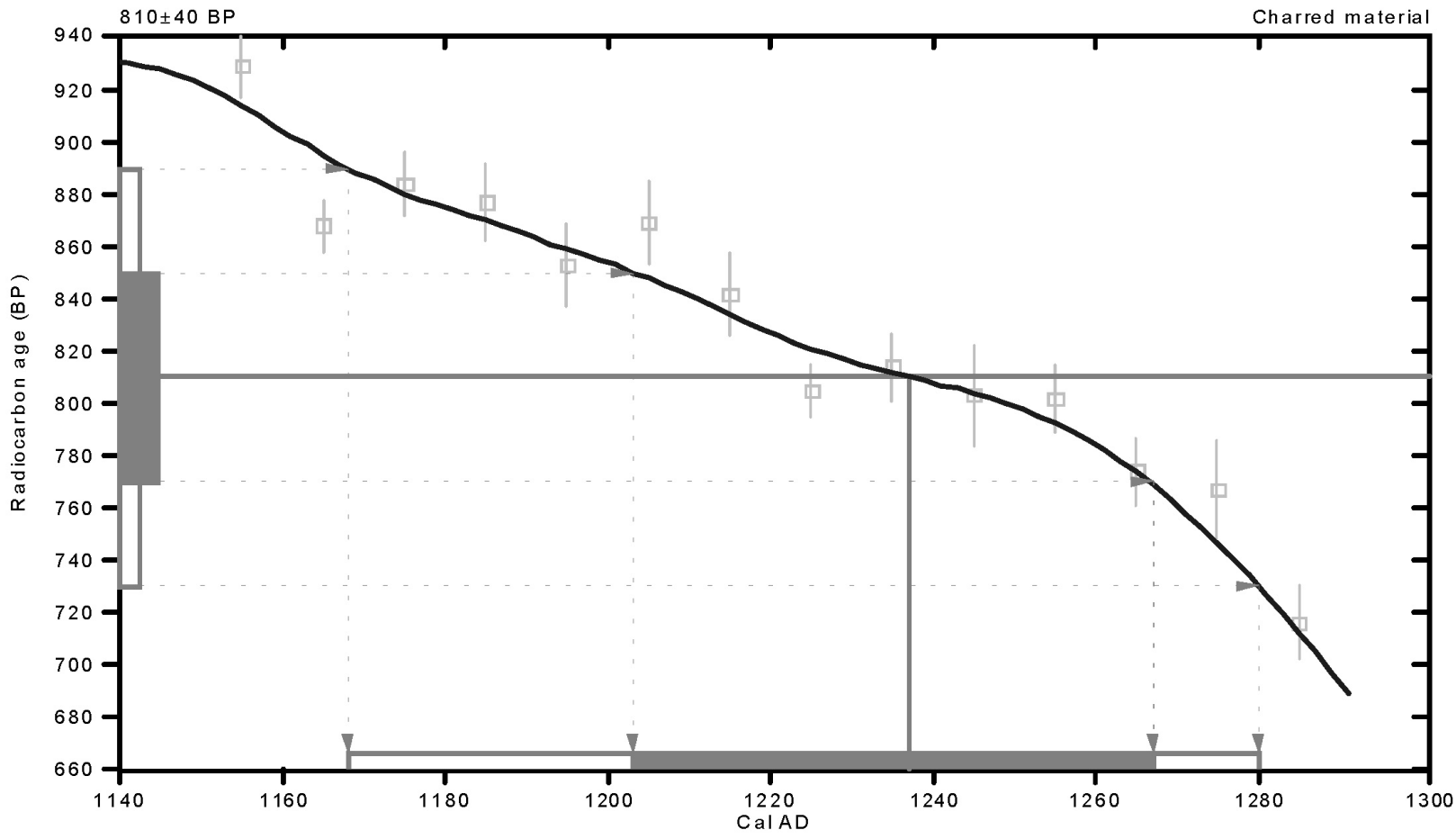

References:

Database used

Calibration Database

Editorial Comment

Stuiver, M., van der Plicht, H., 1998, Radiocarbon 40(3), pxil-xili

INTCAL98 Radiocarbon Age Calibration

Stuiver, M., et. al., 1998, Radiocarbon 40(3), p1041-1083

$M$ ath ematics

A Simplified Approach to Calibrating C14 Dates

Talma, A.S., Vogel, J.C., 1993, Radiocarbon 35(2), p317-322

\section{Beta Analytic Inc.}

4985 SW 74 Court, Miami, Florida 33155 USA Tel: (305) 6675167•Fax:(305)6630964・E-Mail: beta@radiocarbon.com 


\section{CALIBRATION OF RADIOCARBON AGE TO CALENDAR YEARS}

\section{(Variables: C $13 / \mathrm{C} 12=-25.8:$ lab. $\mathrm{mult}=1$ )}

Laboratory number: Beta-173029

Conventional radiocarbon age: $750 \pm 40$ BP

2 Sigm a calibrated result: Cal AD 1220 to 1300 (Cal BP 730 to 650)

$(95 \%$ probability)

Intercept data

Intercept of radiocarbon age

with calibration curve:

1 Sigm a calibrated result:

(68\% probability)

Cal A D 1270 (Cal B P 680)

Cal A D 1260 to 1290 (Cal B P 690 to 660 )

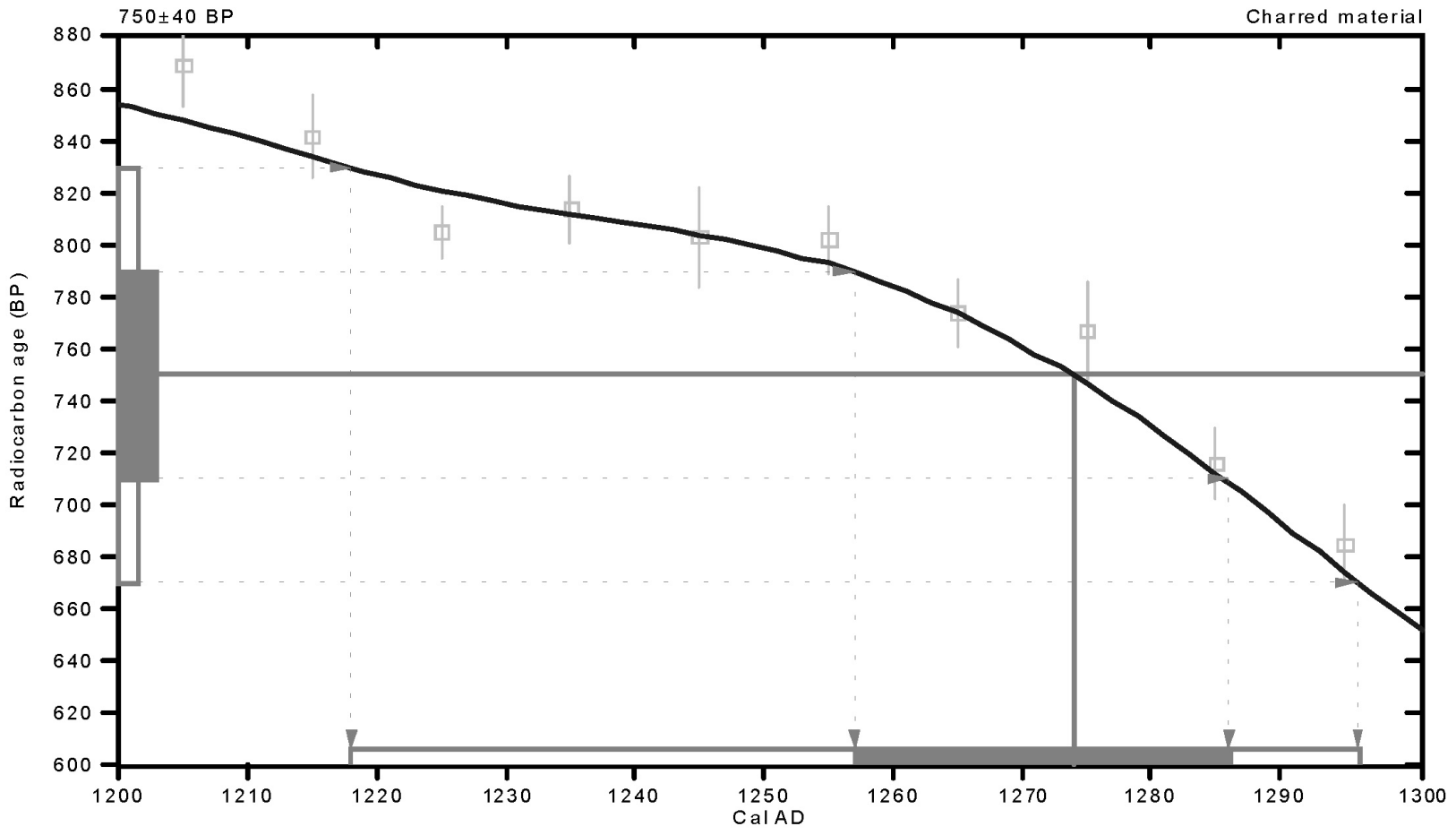

References:

Database used

Calibration Database

Editorial Comment

Stuiver, M., van der Plicht, H., 1998, Radiocarbon 40(3), pxii-xiii

IN TCAL98 Radiocarbon Age Calibration

Stuiver, M., et. al., 1998, Radiocarbon 40(3), p1041-1083

$M$ ath ematics

A Simplified Approach to Calibrating C14 Dates

Talma, A. S., Vogel, J. C., 1993, Radiocarbon 35(2), p317-322

\section{Beta Analytic Inc.}

4985 SW74 Court, Miami, Florida 33155 USA Tel: (305)6675167•Fax:(305)6630964・E-Mail:beta@radiocarbon.com 


\section{Appendix B}

\section{Ethnobotanical Remains}




\section{Appendix B: Plant Remains from Sites 41BR392, 41BR500, and 41BR522 Located on Camp Bowie, Brown County, Texas}

\section{J. Philip Dering}

Recent studies of burned rock middens located on a tributary of the Colorado River in Brown County, Texas have determined unequivocally that plant processing constituted a primary use of the earth ovens excavated at these sites. In a previous analysis conducted on samples from Camp Bowie sites, approximately 384 charred bulbs and tuber or corm fragments were noted in 76 macrobotanical and 35 flotation samples recovered from nine archaeological sites. The current analysis examines plant material in 50 macrobotanical and seven flotation samples from an additional three sites.

\section{Methods}

\section{Preliminary Sorting}

The analysis began by following standard archaeobotanical laboratory procedures. Specimens were sorted into general categories such as wood, seed, or bulb/corm/tuber using an epi-illuminated light microscope at 8-35 power. Identification of carbonized wood was accomplished by using the snap technique, examining them at 8 to 45 magnifications with a hand lens or a binocular dissecting microscope, and comparing them to references in the archaeobotanical herbarium. Seeds, when present, were compared to the reference collection housed in the archaeobotanical laboratory. A series of analytical procedures tailored to the identification of vegetative plant remains was utilized.

\section{Identification of Geophytes}

Geophytes are plant species that reserve energy in specialized underground storage organs. Underground storage organs of geophytes occur in many different forms depending on what part of the plant the organ is derived from. Each specific type has been given a name, such as bulbs, tubers, corms, or rhizomes, to name a few of the types of geophytes. These organs function to store food reserves, nutrients, and moisture for seasonal growth and development enhancing the plant's ability to overwinter or survive long periods of drought. The geophyte genera include both monocotyledonous and dicotyledonous species, and they can be separated into two groups, bulbous and tuberous (De Hertogh and Le Nard 1993:7). Geophytes are diverse both morphologically and physiologically, and an understanding of their morphology is essential for identification.

Because there is no taxonomic description or identification key to aid in the identification of geophytic structures, the materials in the current analysis were difficult to identify. Plants are primarily classified and identified by the structure of their flowers and fruits, and to a lesser degree by molecular signatures. For this reason there are no keys to the vegetative parts of non-woody plants.

The first step toward identification of geophytes is to determine if they are bulbs, corms, or tubers, etc. Of the many possible structures manifested in geophytes, only bulbs were noted in the current study. Generally speaking, bulbous plants have storage tissues that originate from modified leaves, and tuberous plants have storage tissues that originate from modified stems.

Bulbs are perhaps the most distinctive and easily recognizable of the geophytic taxa. A bulb consists of a shortened stem called a basal plate that has one or more apical meristems and is enclosed by several fleshy scales (modified leaves), usually arranged in a rosette pattern very similar to an artichoke. The basal plate also contains adventitous root initials. Thus the "leaves" or leaf scales sprout from the top of the basal plate and the roots from the bottom of the same structure, an arrangement easily recognizable in any cultivated onion. The swollen leaf scales are the primary storage tissue in true bulbs. Depending on the species, scales are modified leaves or leaf bases that are enlarged with fleshy tissue that stores food and water. Some bulbs are protected by a covering of dried leaf scales called a tunic. Bulbs can be either annual or perennial.

There is great diversity among the true bulb species and several bulb-forming plants are likely to be recovered from archaeological sites, including several species of onion (Allium spp.), false garlic (Nothoscordum bivalve (L.) Britt.), Eastern camas (Camassia scilloides (Raf.) Cory), dog'stooth violet (Erythronium mesochoreum Knerr.), and prairie celestial (Nemastylis geminiflora Nutt.). In the current analysis, however, only camas was noted. 


\section{Examining Archaeological Material}

Due to the variables encountered in identifying geophytes, adequate identification of geophytic material recovered from archaeological sites requires a systematic examination of the specimen beginning with the description of the gross morphology and ending with microscopic examination of certain characters. For the Camp Bowie materials, the following steps were taken:

1) Each specimen was examined under a low-power epi-illuminated dissecting microscope. Gross anatomical features were noted, including whether bulb scales and a central stem were present.

2) If no bulb scales were present, the sample was snapped or cut in the transverse axis to determine if the tissue was organized like a stem (xylem - a corm) or a root (cortex - a tuber).

3) If the material was a true bulb, the bulb scales were examined for the presence of epidermis. If epidermal features were discovered, some of the material was attached to an aluminum stub for examination using a scanning electron microscope.

4) Bulbs and bulb fragments were examined at $8-125 X$ with a Leica MZ 125 stereomicroscope linked to a digital camera. The Leica MZ 125 stereomicroscope is equipped with servo-focusing linked to Image-Pro software. The camera produces multiple images at several distances from the specimen, focusing through the specimen and saving each image. The software reassembles the multiple images into a single, in-focus image of the entire specimen.

\section{Results}

The results present descriptions which attempt to bridge the gap between technical botanical terminology and more accessible language. In this study, for example, only wood charcoal and bulbs or bulb fragments were noted. For the purposes of clarity, I describe the bulb remains as either a "bulb" or as "leaf scale fragments." A bulb refers to an object that includes leaf scales still attached in layers to the central stem/basal plate. The term "bulb" does not imply that the entire bulb is present, for some of the outer layers may have peeled off. Rather it describes an object that retains most of the features of a bulb and is obviously recognizable as a bulb. The individual leaf scales, or layers, that peel off of a bulb are referred to as "leaf scale fragments." These are concavo-convex fragments of charred material that have become separated from the bulb.

\section{Flotation Samples}

The seven flotation samples contained 55 wood fragments weighing 1.1 grams, referable to oak, mesquite, woody legume (acacia or mesquite), or an unidentifiable category (Table B-1). Three small bulb fragments were recovered from two of the flotation samples, but these were not identifiable. Three of the seven flotation samples did not contain any carbonized plant remains larger than flecks $(<1 \mathrm{~mm})$.

\section{Macrobotanical Samples}

Ten macrobotanical or screen/point-collected samples from two sites, 41BR392 and 41BR522, contained a total of 48 bulbs or bulb fragments weighing approximately 5.8 grams (Table B-2). Although most of the bulbs or fragments did

Table B-1. Plant Materials from Flotation Samples

\begin{tabular}{|c|c|c|c|c|c|c|c|}
\hline 41BR & Sample & Provenience & Name & Common & Part & Count & Wt. (gr) \\
\hline 392 & 96-004-001 & TU3-L5, Lot $96-$ FS113 & Prosopis sp. & Mesquite & Wood & 1 & 0.1 \\
\hline 392 & 96-004-001 & TU3-L5, Lot $96-$ FS113 & Indeterminable & NA & Wood & 22 & 0.1 \\
\hline 392 & 96-004-001 & TU3-L5, Lot 96 - FS113 & Indeterminable & NA & Slag & 1 & 0.1 \\
\hline 392 & 93-001-001 & TU5-L3, Lot 93 - FS153 & No Carbonized Plant Remains & & & & \\
\hline 500 & 64-001-001 & TU4-L5, (40-50cm)-Lot 64 & No Carbonized Plant Remains & & & & \\
\hline 500 & 58-001-001 & TU4-L4, (30-40cm)-FS68, Fea 1 & No Carbonized Plant Remains & & & & \\
\hline 522 & 47-003-001 & TU3-L4, Lot 47 - FS 36 & Indeterminable Legume & NA & Wood & 18 & 0.5 \\
\hline 522 & $51-001-1$ & TU2-L5A, Lot 51- FS46 & Quercus sp. & Oak & Wood & 14 & 0.4 \\
\hline 522 & $51-001-1$ & TU2-L5A, Lot 51 - FS46 & Indeterminable & NA & Bulb & 2 & 0.1 \\
\hline 522 & $36-001-001$ & TU3-L2, Lot 36 --FS26 & Indeterminable & NA & Bulb & 1 & 0.1 \\
\hline 522 & $36-001-001$ & TU3-L2, Lot $36-$ FS26 & Indeterminable & NA & Slag & 2 & 0.1 \\
\hline
\end{tabular}


not exhibit diagnostic features (observable epidermal tissue), three leaf scale fragments were identified as camas. In addition to the bulb fragments, three samples contained carbonized oak wood. The 22 wood fragments weighed 2.3 grams.

\section{Results from 41BR392}

One screen/point-collected sample and two flotation samples were examined from this site. Of the two flotation samples examined, the sample from TU 5, was empty. A second flotation sample from TU 3 contained mesquite wood charcoal along with unidentifiable wood and slag or exudate. The single screen/point-collected sample contained an intact bulb with a recognizable central stem and leaf scales. Leaf scales examined from the bulb did not exhibit diagnostic characteristics and the bulb was classified as indeterminate.

\section{Results from 41BR500}

Two flotation samples from this site did not contain carbonized seeds or any charred plant material larger than flecks $(<1 \mathrm{~mm})$.

\section{Results from 41BR522}

Seven screen/point-collected samples and three flotation samples were examined from this site. The flotation samples contained oak wood charcoal (14 fragments weighing
.4 grams) and three leaf scale fragments. 41BR522 contained most of the plant remains noted in the flotation samples. Screen/point-collected samples contained several bulb fragments as well as oak wood.

Charred wood was recovered from four different test units at the site. TUs 2, 4, and 5 contained oak wood and TU 3 contained legume wood which was most probably mesquite. Unfortunately, the legume wood charcoal did not exhibit anatomical features that would allow me to separate it into one of the many legume taxa such as mesquite, acacia, or honey locust.

Intact bulbs and/or bulb leaf scale fragments were recovered from every test unit represented in the botanical analysis of 41BR522. TU 1 contained 12 intact bulbs and seven leaf scale fragments. Samples from TU 2 contained five small bulb fragments (leaf scales). These leaf scales did not exhibit diagnostic epidermal features, and could not be identified. TU 3 contained a single bulb and two fragments of slag or exudate. Most likely this shiny black substance represents sap that boiled out of bulbs and became carbonized as it was overheated during the cooking process.

Three screen/point-collected samples from TU 4 contained 10 bulbs and three leaf scale fragments. Three fragments of this material is identifiable as Eastern camas. TU 5 contained eight bulbs and nine bulb fragments. Bulb material was dispersed from Level 2 through Level 6.

Table B-2. Macrobotanical (screen or point-collected) Samples

\begin{tabular}{cllllllcc}
\hline 41BR & Cat & Lot/FS & Provenience & Name & Common & Part & Count & Wt. (gr) \\
\hline 522 & $49-003$ & $49 / 43$ & TU4-L5 & & & Bulb fragment & 3 & 0.2 \\
522 & 56 & $56 / 57$ & TU4-L4 & Quercus sp. & Oak & Wood & 10 & 1.5 \\
522 & 63 & $63 / 67$ & TU4-L5 & & Bulb & 1 & 0.2 \\
522 & $75-004$ & $75 / 93$ & TU2-L5b & & Bulb fragment & 3 & 0.5 \\
522 & $76-003$ & $76 / 95$ & TU5-L6 & & Bulb fragment & 9 & 1.2 \\
522 & $80-002$ & $80 / 104$ & TU5-L5 & Quercus sp. & Oak & Wood & 11 & 0.7 \\
522 & $80-002$ & $80 / 104$ & TU5-L5 & & & Bulb & 1 & 0.2 \\
522 & $77-004$ & $77 / 100$ & TU1-L6 & & Bulb & 14 & 2 \\
522 & $54-001$ & $54 / 53$ & TU4-L3 & & Bulb & 9 & 0.6 \\
522 & $74-004$ & $74 / 90$ & TU5-L5 & & Bulb & 7 & 0.7 \\
522 & $74-004$ & $74 / 90$ & TU5-L5 & Quercus sp. & Oak & Wood & 1 & 0.1 \\
392 & $96-003$ & NA & TU3-L5 & & & Bulb & 1 & 0.2 \\
\hline
\end{tabular}




\section{Discussion: 41BR392, 41BR500, and 41BR522}

Of the three sites investigated in this analysis, two contained identifiable plant remains. Eastern camas bulbs/bulb fragments were the only food plant resource identified in the current study. In addition to the Eastern camas bulbs, oak and mesquite wood were noted in the samples. The presence of mesquite wood by implication suggests mesquite pod use, but does not specifically identify human activities that include mesquite processing. Likewise, oak wood at least indicates a potential for acorn processing. However, the presence of bulbs at 41BR392 and 41BR522, in the context of large quantities of fire-cracked rock, adds to a strengthening argument that geophytes provided a substantial contribution to the subsistence of Late Prehistoric period foragers along the southern edge of the Great Plains.

Table B-3 provides a list of geophytes that have been recovered from sites in and adjacent to the central, eastern, and northern peripheries of the Edwards Plateau. In addition to the six Camp Bowie sites in Brown County, camas has been reported from four other sites in three additional counties. Each of these counties is situated on the periphery of the Edwards Plateau-Caldwell County on the southeastern edge, Williamson County on the eastern edge, Coryell County on the northeastern periphery, and Brown County on the northern periphery of the plateau.

Onions have been recovered from five sites along the southern and eastern periphery of the Edwards Plateau and from three sites in Brown County, located on the northern periphery. In addition to these locations, wild onions occur in high density and frequency in the excellently preserved middens of rockshelters located in the Lower Pecos region on the southwestern edge of the Edwards Plateau. Although Table B-3 includes six rockshelter sites with onion fragments in the deposits, onion was so widely and intensely harvested in the area that it is likely that dozens of sites with dry midden deposits contain wild onions.

\section{Ethnographic References to Geophytes on the Southern Plains Periphery}

The question of why root foods, especially bulbs, are not well recorded in ethnohistorical records is worth asking. Do the few records that note mass consumption provide an accurate representation of the actual subsistence practices of these groups? Or is this practice severely underrepresented in the written record?

While the ethnographic and ethnohistoric literature contains dozens of general references to the Native American use of geophytes (primarily onions), few provide much satisfying detail. The fact that only two or three historical descriptions give any details of geophyte processing stands in contrast to the thousands of earth oven features or burned rock middens located along the southern edge of the Great Plains. Many ethnobotanical sources are biased by difficult to perceive factors such as the purpose for which the recorder is traveling, the time of year, or the degree of involvement of the observer. Europeans were not predisposed to an interest in geophytes primarily because they came from a society that relied almost exclusively on grain, fruits, and nuts for carbohydrates. To complicate the issue, consumption of most geophytes is either controlled by season or moisture availability, reducing the time window during which a traveler could actually witness the collection and processing of these resources. And finally, many travelers made their observations after the Old World onion and other cultigens had diffused across the Americas, after which the use of the wild onion would have been relegated to a dim memory (see Gilmore 1977). For these reasons, I believe that the records presented herein complement the archaeological record, and help to illuminate, rather than detract from it.

\section{Eastern camas (Camassia scilloides (Raf.) Cory)}

Eastern camas has been identified from seven sites in Texas, in addition to the sites in the current study. The genus Camassia contains about five species, at least three of which have recorded food value (Gould 1942). Although there is a large body of literature addressing the use of some camas species (Camassia quamash or Camassia leichtlinii) in the northwest, there is little ethnographic information available for Eastern camas. I have been able to locate two records of Eastern camas use, both from Oklahoma, and both by Comanche.

In a visit to the Comanche Indian Reservation near Indiahoma, Oklahoma, Carlson and Jones (1940:528) recorded a description of Eastern camas use. There is no mention of fire, nor of any detailed preparation method.

A more detailed description from near the Texas-Oklahoma border is provided by Sternberg (1931:223). He made the observation in 1882 , and noted that the Comanches 


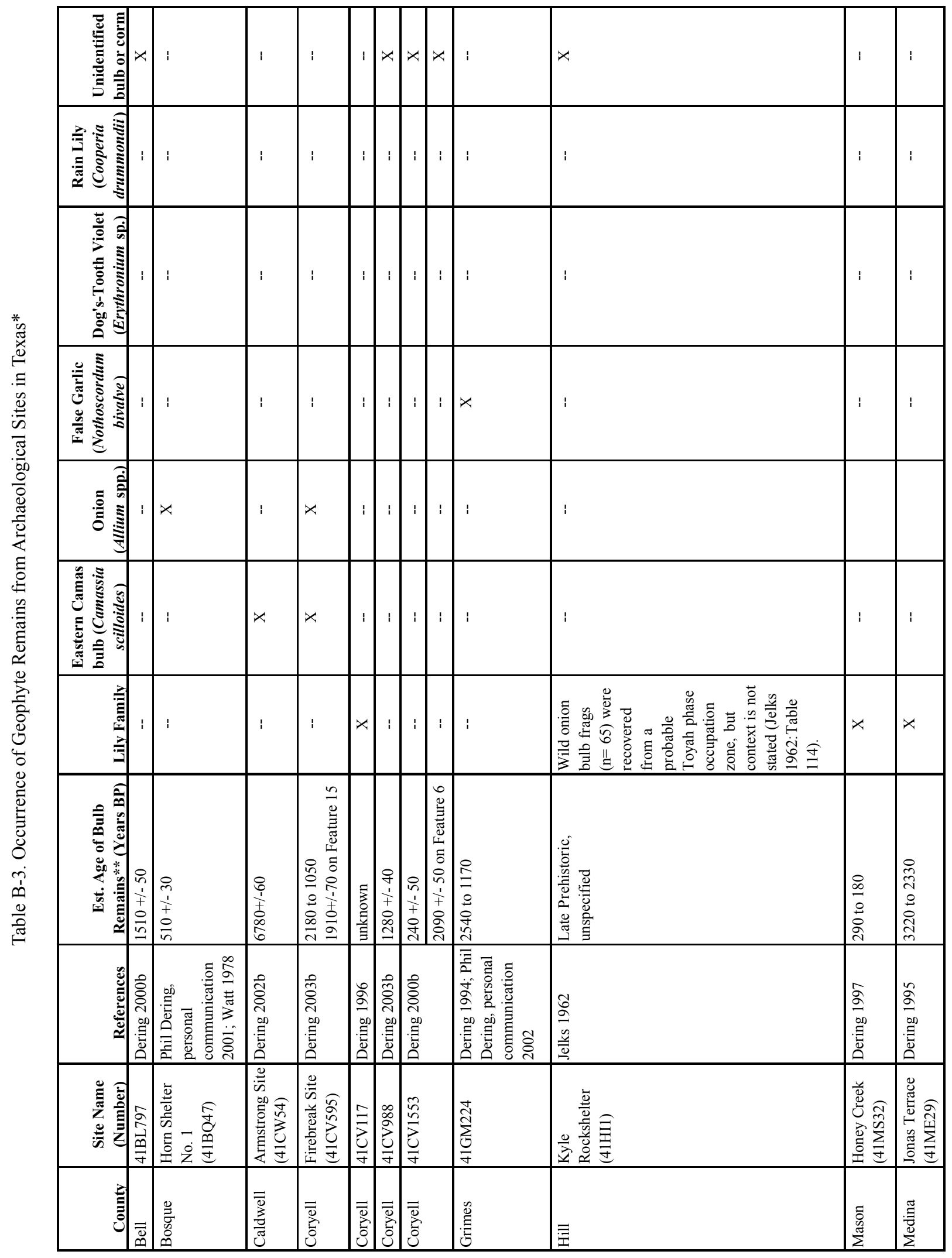




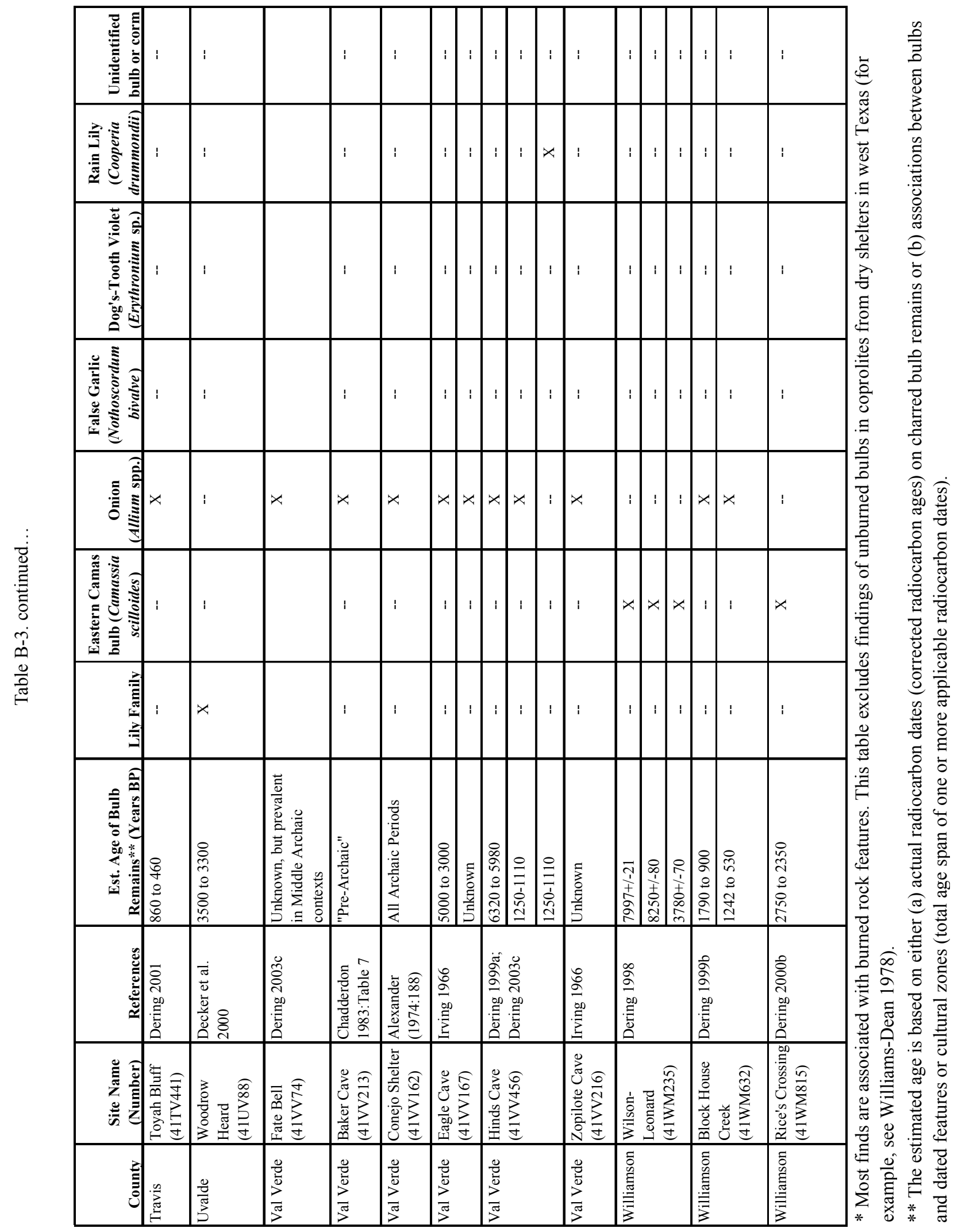


excavated a pit "...five feet deep and three in diameter and kindled a fire at the bottom, using at least a cord of wood..." (Sternberg 1931:223). There is no mention of a rock heating element, but he does say that "...the ashes were scraped out, and the wall plastered with a mortar of mud, over which green grass was thickly strewn to prevent the bulbs from burning..." (Sternberg 1931:223). This description raises the issue of the accuracy of even eyewitness accounts. The description of a cord of wood is in line with both eyewitness descriptions of earth oven use, and with experiments. However, the pit measurements are too small. A cord of wood measures roughly $4 \times 4 \times 8$ feet $\left(128 \mathrm{ft}^{3}\right)$, and the pit was described as being three feet wide and five feet deep, about $35 \mathrm{ft}^{3}$. Granted, wood is usually stacked in a pile at least five feet above a pit, and that would double the fuelload volume to about $70 \mathrm{ft}^{3}$. The lack of a rock heating element is not very credible. In the 23 or so earth ovens I have built, I have never been able to heat the ground to a temperature that would require lining the pit with moist packing material. Packing material is necessary only when a rock heating element is present, and Sternberg describes the use of packing material to prevent ignition of the food load.

These are typical of the inconsistencies often encountered in the ethnohistoric descriptions of plant processing, but the problems with Sternberg's description of the process do not negate its value. To the contrary, much of the account is credible, especially the use of fire and the size of the fuel load. It is clear from the description that Sternberg arrived at the camp after the oven was fired and the food placed in it. He most likely missed the rock element because it is difficult to see much detail in a smoldering pit.

\section{Wild onion (Allium sp.)}

Ethnographic and historic records of wild onion use are widespread across North America. Texas is an important center of diversity and dispersal of the genus Allium, and 12 of the 17 or so species of Allium noted in North America occur in the state (Ownbey 1950). Therefore, most of the ethnographic observations refer to onion species that occur in Texas. Narrowing the search to references that refer to pit-baking or roasting onions (i.e., bulk processing), at least nine ethnohistoric groups are mentioned, including the Pomo, Ramah Navajo, Paiute, and Gosiute, as well as several groups in the Pacific northwest (Dering 2002a).
Unfortunately, none of records from Texas describe pitbaking, and the best descriptions come from the western states. For example, Barret (1952:89) notes that the Pomo of northern California baked onions in an underground oven. The best description of bulk processing comes from the Surprise Valley Paiute. This group collected Allium in large quantities, two to five sacks at a time. They dug a pit and built a fire of unspecified size to which they added small stones. The food load was placed in the oven, covered with grass and earth, and left overnight (Kelly 1933:102).

At this time, it is not possible to identify charred onions beyond the genus level, but the caves and rockshelters of Val Verde County contain rich deposits of desiccated, uncharred plant materials. In these contexts, onions are identified from the discarded remains of reticulate tunics of anastomosing fibers that wrap around the bulb. These are not seen in open sites because the tunic probably would not survive a heating event that would carbonize the bulb itself. However, in the dry, organic-rich rockshelter deposits these bulb tunics appear in significant frequency and abundance. The presence of reticulate tunics is characteristic of two widespread onion species, Allium canadense and Allium drummondii. Of these two, it appears that Allium canadense, which is distributed throughout the eastern half of North America including the Great Plains, was the mainstay of the geophytic resources in the region. Some tunics resembling Allium drummondii occur in much lower abundance in the rockshelters.

Allium canadense is a complex species with at least five subspecies assigned to it (Ownbey 1950). Allium drummondii is a species that is distributed primarily on limestone-derived soils throughout Texas, northern Mexico, and New Mexico north to western Nebraska. The use of these onions was very widespread across the Great Plains and adjacent areas by groups including the Cheyenne, Lakota, Osage, Omaha, Ponca, Pawnee, and Blackfoot (Gilmore 1977:19; Grinnell 1923; Rogers 1980).

It is clear from the preceding that records of onion use on the Great Plains are widespread. Details of use are, however, reduced to sketchy footnotes that portray wild onions as condiments, snacks, or a relic of the past that suffered replacement by the Old World cultivated onion. An intriguing exception to these accounts is the brief mention by Valerie Havard, a naturalist who traveled through Texas into the southwest in the late 1800s. 
The bulbs of all the species of Allium, or garlic, are more or less edible and nutritious in spite of the strong-scented volatile oil they contain; many references are made to the "Wild Leekes" and "Wild Onions" by the first explorers who were sometimes compelled to follow the example of the Indians and eat them to sustain life; however it was their abundance all over the land which gave them value rather than their quality (Havard 1895:1 13).

Although Havard did not appreciate the "quality" of onions, he did recognize their availability and use as a carbohydrate source. Piecing together the few ethnobotanical or historical references that provide some detail of geophyte consumption, it becomes clear that many Native American groups consumed onions and other geophytes as an important source of carbohydrates, e.g., "to sustain life."

\section{Conclusions}

Table B-3 presents a record of geophyte remains identified from 21 archaeological sites in central/southwestern TexasEastern camas, wild onion, false garlic, dog's-tooth violet, and rain lily. To name some of the more prominent sites, plant bulbs have been recovered from well-described burned rock features at Hinds Cave (41VV456), the Wilson-Leonard site (41WM235), the Jonas Terrace site (41ME29), Blockhouse Creek (41WM632), the Honey Creek site (41MS32), Horn Shelter (41BQ4), Rice's Crossing (41WM815), and the Geophyte Site (41CV595) located on Fort Hood in Coryell County (Dering 1996, 1999a, 1999b, 2000a, 2000b). This is a significant body of data, considering what we understood about the botany of burned rock middens a decade ago.

The Camp Bowie sites add a tremendous amount of information to the archaeological record of geophytes in sites on the Southern Plains periphery. In the current analysis, two more sites (41BR392 and 41BR522) yielded charred bulbs recovered from fire-cracked rock features. This adds to the nine Camp Bowie sites from which bulbs have already been recovered (Dering 2003a).

The time depth for the utilization of geophytic resources and earth oven processing extends from $8000 \mathrm{BP}$ to $150 \mathrm{BP}$. The earliest date is from an earth oven at the Wilson-Leonard site in Williamson County, and the most recent from $41 \mathrm{CV} 1553$ in Coryell County. These dates demonstrate that geophytes contributed to subsistence throughout the Holocene.

Bulbs and bulb fragments have now been recovered from 31 sites in and around the Edwards Plateau of Texas. This assemblage of plant materials provides evidence that the earth ovens in this region were utilized to process geophytes. The growing body of data continues to strengthen the argument that geophytes were a primary carbohydrate source to the Southern Plains foragers of the Archaic and Late Prehistoric periods. 


\section{References Cited}

Alexander, R. K.

1974 The Archeology of Conejo Shelter: A Study of Cultural Stability at an Archaic Rockshelter Site in Southwestern Texas. Ph.D. dissertation, Department of Anthropology, The University of Texas at Austin.

Barret, S. A.

1952 Material Aspects of Pomo Culture: Part One. Bulletin of the Public Museum of the City of Milwankee 20:1-260.

Carlson, G. G., and V. H. Jones

1940 Some Notes on Uses of Plants by the Comanche Indians. Papers of the Michigan Academy of Science, Arts, and Letters 25:517-542.

Chadderdon, M. F.

1983 Baker Cave, Vale Verde County, Texas: The 1976 Excavations. Special Report 13. Center for Archaeological Research, The University of Texas at San Antonio.

De Hertogh, A. A., and M. Le Nard

1993 Botanical Aspects of Flower Bulbs. In The Physiology of Flower Bulbs, edited by A. A De Hertogh and M. Le Nard, pp. 7-20. Elsevier Press, Amsterdam.

Decker, S., S. L. Black, and T. Gustavson

2000 The Woodrow Heard Site, 41UV88: A Holocene Terrace Site in the Western Balcones Canyonlands of Southwestern Texas. Studies in Archeology 33, Texas Archeological Research Laboratory, The University of Texas at Austin; Archeology Studies Program, Report 14, Environmental Affairs Division, Texas Department of Transportation, Austin.

Dering, P.

1994 Plant Remains from 41GM224, Grimes County, Texas. In Excavations at Site 41GM224 in the Gibbons Creek Lignite Mine Permit 38A Area, Grimes County, Texas, by R. Rogers. Appendix D. Espey, Huston and Associates, Inc., Austin, Texas.

1995 Appendix II: Macrobotanical Analysis of Deposit Samples. In Past Cultures and Climates at Jonas Terrace, 41ME29, Medina County, Texas, by L. Johnson, pp. 301-305. Office of the State Archeologist, Report No. 40. Texas Historical Commission, Austin.

1996 Utilization of Geophytes on the Southern Plains: Identification and Assessment of a Once Archaeologically "Invisible" Resource. Paper Presented at the 61st Annual Meeting of the Society for American Archaeology, April 10-14, 1996, New Orleans, Louisiana.

1997 Macrobotanical Remains. In Hot Rock Cooking on the Greater Edwards Plateau: Four Burned Rock Midden Sites in West Central Texas, edited by S. L. Black, pp. 573-600. Texas Archeological Research Laboratory, Studies in Archeology 22, The University of Texas at Austin.

1998 Carbonized Plant Remains. In Wilson-Leonard: An 11,000-year Archeological Record of Hunter-Gatherers in Central Texas. Volume V: Special Studies, assembled and edited by M. B. Collins, pp. 1609-1636. Studies in Archeology 31. Texas Archeological Research Laboratory, The University of Texas at Austin.

1999a Earth Oven Processing in Archaic Period Economics: An Example from a Semi-Arid Savannah in South-Central North America. American Antiquity 64(4):659-674.

1999b Appendix B: Flotation Sample Identifications and Counts. In Archaeological Investigations at Block House Creek, Williamson County, Texas, edited by M. Bowden. Parsons Brinckerhoff Quade and Douglas, Inc., Austin, Texas. 
2000a Plant Remains from the Blockhouse Creek Sites, Williamson County, Texas. Manuscript on file at the Center for Ecological Archaeology, Texas A\&M University, College Station.

$2000 \mathrm{~b}$ Plant Remains from Rice's Crossing (41WM815), Williamson County, Texas. Manuscript on file at the Center for Ecological Archaeology, Texas A\&M University, College Station.

2001 Macrobotanical Analysis of Samples from 41TV441, the Toyah Bluff Site. Manuscript on file at the Archaeobotanical Laboratory, Texas A\&M University, College Station.

2002a An Annotated Bibliography of Geophyte Use with Emphasis on Texas Species. Manuscript on file, Department of Anthropology, Texas A\&M University, College Station.

2002b Appendix F: Plant Remains from the Armstrong Site. In Data Recovery at the Armstrong Site (41CW54) Caldwell County, Texas Volume 1: Background, Methods, and Site Context, by E. A. Schroeder and E. R. Oksanen, pp. 265-276. PPA Cultural Resources Report Number 0284.

2003a Appendix C: Botanical Perspectives on Land Use in the Cross Timbers and Prairies. In Archaeological Testing to Determine the National Register Eligibility Status of 18 Prehistoric Sites on Camp Bowie, Brown County, Texas, Volume 2, by R. P. Mauldin, D. L. Nickels, and C. J. Broehm, pp. 58-78. Archaeological Survey Report, No. 334. Center for Archaeological Research, The University of Texas at San Antonio.

2003b Appendix B: Analysis of Macrobotanical Remains from Three Paluxy Sites, Fort Hood, Texas. In Shifting Sands and Geophytes, Geoarcheological Investigations at Paluxy Sites on Fort Hood, Texas, by G. Mehalchik, D. K. Boyd, K. W. Kibler, and C. W. Ringstaff. Archeological Resource Management Series, Research Report No. 48. United States Army, Fort Hood, Texas.

2003c Continuing Analysis of Plant Remains from Rockshelter Sites in the Lower Pecos Region, Texas. Manuscript on file at Shumla Archeobotanical Services, Comstock, Texas.

Gilmore, M. R.

1977 Uses of Plants by the Indians of the Missouri River Region. University of Nebraska Press, Lincoln. Reprint of 1919 33rd Annual Report of the Bureau of American Ethnology.

Gould, F.

1942 A Systematic Treatment of the Genus Camassia Lindl. American Midland Naturalist 28(3):712-742.

Grinnell, G. B.

1923 The Cheyenne Indians, Their History and Ways of Life. 2 volumes. Yale University Press, New Haven.

Havard, V.

1895 Food Plants of the North American Indians. Bulletin of the Torrey Botanical Club 22:98-123.

Irving, R. S.

1966 The Preliminary Analysis of Plant Remains from Six Amistad Reservoir Sites. In A Preliminary Study of the Paleoecology of the Amistad Reservoir Area, edited by D. A. Story and V. M. Bryant, Jr., pp. 61-90. Texas Archeological Salvage Project. The University of Texas at Austin.

Jelks, E. B.

1962 The Kyle Site. A Stratified Central Texas Aspect Site in Hill County, Texas. Archaeology Series 5. Department of Anthropology, The University of Texas at Austin.

Kelly, I.

1993 Ethnography of the Surprise Valley Paiute. University of California Publications in American Archaeology and Ethnography 31:67-210. 
Ownbey, M.

1950 The Genus Allium in Texas. Research Studies of the State College of Washington 28(4):181-222.

Rogers, D.

1980 Lakota Names and Traditional Uses of Native Plants by Sicangu (Brule) People in the Rosebud Area, South Dakota. The Rosebud Educational Society. St. Francis, South Dakota.

Sternberg, C. H.

1931 The Life of a Fossil Hunter. Jensen Printing Company, San Diego, California.

Watt, F.

1978 Radiocarbon Chronology of Sites in the Central Brazos Valley. Bulletin of the Texas Archeological Society 49: 111-138.

Williams-Dean, G.

1978 Ethnobotany and Cultural Ecology of Prehistoric Man in Southwest Texas. Unpublished Ph.D. dissertation. Department of Biology, Texas A\&M University, College Station. 


\section{Appendix C}

\section{Magnetic Sediment Susceptibility Testing}




\title{
Appendix C: Magnetic Sediment Susceptibility Testing
}

\author{
Raymond P. Mauldin
}

The magnetic susceptibility (MS) of a given sediment sample can be thought of as a measure of how easily that sample can be magnetized (Dearing 1999; Gose and Nickels 2001). At low magnetic field strengths, this measure is primarily related to the concentration and grain size of ferromagnetic and ferrimagnetic minerals in the sample (Gose and Nickels 2001). A number of processes can result in an increase in MS values in a sediment sample. Of these processes, those that are of concern here are related to an increase in the organic constitutes or changes in the mineralogy of sediments in a given sample (see Collins et al. 1994; McClean and Kean 1993; Singer and Fine 1989). Sediments with higher organic content tend to have higher magnetic susceptibility values, probably as a result of the production of maghemite, an iron oxide, during organic decay (Reynolds and King 1995). Pedogenic processes, such as soil formation and weathering, can result in the concentration of organic material, as well as alterations in the mineralogy of a given zone. These processes can significantly impact susceptibility readings. Cultural processes, such as the concentration of ash, charcoal, and refuse, as well as heating of sediment associated with thermal features, would also produce higher MS readings. A measure of the magnetic susceptibility of a sediment sample, then, may provide information on both the presence of surfaces, as well as a measure of the concentration of cultural activity upon those surfaces.

\section{Collection Procedures and Laboratory Methods}

Sixty-four samples from two sites (41BR392 and 41BR500) were analyzed on the current project. Nineteen of the 30 samples from 41BR392 came from TU 3, located in the ring of the burned rock midden tested at this site. The remaining 11 samples were collected from TU 4, located outside of the midden. On 41BR500, four different test units were sampled. From the three adjacent units (TUs 1, 2, and 3), 19 samples were collected. From TU 4, located in the southern area of the undisturbed portion of the site, 15 samples were collected. All samples were collected at $5-\mathrm{cm}$ intervals along a profile face. All samples were placed in plastic vials and stored in the laboratory at CAR until analysis.
Sediment samples were air dried on a non-metal surface. After drying, it was sometimes necessary to grind the samples into a uniform grain size using a ceramic mortar and pestle. This was done to standardize particle size and make the material both easier to handle and pack into sample containers. After each sample was prepared, the mortar and pestle were washed with tap water and wiped dry with a paper towel to avoid cross-sample contamination. The ground sample was then poured into a sample container consisting of a plastic cube with external dimensions of 2.54 x 2.54 x $1.94 \mathrm{~cm}$. The cubes have an average weight of 4.85 grams. The sediment filled cube was then weighed, and the weight of the sample calculated by subtracting the empty cube weight. This was done to correct for differences in mass. Assuming that sample volume and material is constant, larger samples should have higher susceptibility values simply as a function of greater mass.

The cube was then placed into a MS2B Dual Frequency Sensor that, in conjunction with a MS2 Magnetic Susceptibility Meter, provided a measure of the magnetic susceptibility of the sample (see Dearing 1999). For each cube, two readings were taken using the SI (standard international) scale. These readings were averaged to arrive at a mean value. That value, referred to as volume specific susceptibility and noted with the symbol $K_{0}$ (Kappa), is recorded on a scale of $10^{-5}$, though there are no units associated with the value. That is, the value is dimensionless (Dearing 1999).

In order to correct for differences in sample weight, and provide units to the value $K_{\text {, }}$, the mass specific susceptibility value (X) was calculated using the formula

$$
X=\left(K_{0} / p\right)
$$

where $\mathrm{p}$ is the sample bulk density expressed in $\mathrm{kg} \mathrm{m}^{-3}$. The bulk density is determined by dividing the sample mass by volume. However, as all samples were measured in identical cubes, and all cubes were full, the sample volume is assumed to be constant. Only the mass of the sample varied. Mass specific susceptibility can be determined by

$\mathrm{X}=\mathrm{K}_{\mathrm{o}} *$ calibrated mass/sample mass 
where sample mass is determined by subtracting the cube weight from the total sample weight (Dearing 1999). Calibrated mass is assumed to be 10 grams.

While the resulting values now have both a scale and associated units, the critical element for the current discussion is related to relative differences between $\mathrm{X}$ sample values within a given profile or site, rather than absolute differences. That is, the principal interest is in rapid changes in the mass specific susceptibility values along a profile. This change may signal either a buried surface and/or cultural activity at that location. Comparisons of absolute values between samples from different areas, especially when the parent material of the soils is different, are of limited utility given our current goals.

This can be seen in Table C-1, which lists a variety of examples of mass specific susceptibility values for several different materials. In all cases, the analysis was performed following the procedures outlined previously. Note that the values differ widely, from a low of -1.47 for tap water, to a high of 97.62 for sediments collected from a burned rock midden. Samples 5 and 6 are on two different clays from the same general setting, far northern Lamar County in north Texas. The mass specific susceptibility is different for these samples, probably as a function of different frequencies of trace elements that, though small in absolute quantity, can dramatically impact the susceptibility values.
The potential impacts of cultural processes on susceptibility values can be seen by considering a data set collected from an archaeological site located in Brown County, site 41BR473. A total of 279 sediment susceptibility samples was collected from each level of over 50 shovel tests placed at this site. In all cases, the analytical procedures followed those outlined previously. Table C-2 presents summary data on all 279 cases, along with susceptibility scores for those settings that had FCR or chipped stone present. If cultural inputs result in higher susceptibility values, then it should be the case that significantly higher susceptibility values will be present in levels that have cultural material.

An examination of Table C-2 will demonstrate that this is indeed the case. Levels that have FCR present do have higher scores relative to those that lack FCR. Similarly, those levels that have chipped stone present have a higher average mass specific susceptibility score relative to those that lack chipped stone. As the distribution is approximately normal, a t-test was used to test the overall significance of these differences. In both the FCR and chipped stone comparisons, the test confirms that those levels with cultural material have significantly higher scores than those without cultural material (FCR t-statistic $=5.804, \mathrm{df}=277, \mathrm{p}<.001$; chipped stone t-statistic $=2.674, \mathrm{df}=277, \mathrm{p}=.008$ ). Our preliminary investigations, then, coupled with the previous work, clearly suggest that an analysis of the magnetic susceptibility of sediment can provide additional information on both the presence of buried surfaces, as well as the impact of cultural material on those surfaces.

Table C-1. Magnetic Sediment Susceptibility Data for a Variety of Substances

\begin{tabular}{|l|c|c|c|c|c|c|c|}
\hline Sample Type & $\begin{array}{c}\text { Total Wt. } \\
\text { (gr.) }\end{array}$ & $\begin{array}{c}\text { Sample Wt. } \\
\text { (gr.) }\end{array}$ & $\begin{array}{c}\text { Reading 1 } \\
(\mathbf{k})\end{array}$ & $\begin{array}{c}\text { Reading 2 } \\
(\mathbf{k})\end{array}$ & $\begin{array}{c}\text { Reading 3 } \\
(\mathbf{k})\end{array}$ & $\begin{array}{c}\text { Average } \\
\text { K }\end{array}$ & $\begin{array}{c}\text { Corrected } \\
\text { Mass (X) }\end{array}$ \\
\hline $\begin{array}{l}\text { 1) Sandy sediment with } \\
\text { organics }\end{array}$ & 13.7 & 8.85 & 27.9 & 28 & 28.1 & 28 & 31.64 \\
\hline $\begin{array}{l}\text { 2) Modern mesquite } \\
\text { charcoal and sediment }\end{array}$ & 9.4 & 4.55 & 10.7 & 10.8 & 10.7 & 10.73 & 23.59 \\
\hline 3) Modern oak wood ash & 7.5 & 2.65 & 16.1 & 16.2 & 16.2 & 16.17 & 61.01 \\
\hline $\begin{array}{l}\text { 4) Sediment from burned } \\
\text { rock midden }\end{array}$ & 11.3 & 6.45 & 62.9 & 63 & 63 & 62.97 & 97.62 \\
\hline $\begin{array}{l}\text { 5) Grey clay - no human } \\
\text { occupation }\end{array}$ & 12.6 & 7.75 & 10.4 & 10.3 & 10.4 & 10.37 & 13.38 \\
\hline $\begin{array}{l}\text { 6) Red clay - no human } \\
\text { occupation }\end{array}$ & 10.8 & 5.95 & 11.9 & 12 & 12 & 11.97 & 20.11 \\
\hline 7) Sandstone & 14.7 & 9.85 & 6.9 & 7 & 7.1 & 7 & 7.11 \\
\hline 8) Limestone & 12.7 & 7.85 & -0.5 & -0.5 & -0.5 & -0.5 & -0.64 \\
\hline 9) Tap water & 10.5 & 5.65 & -0.8 & -0.8 & -0.9 & -0.83 & -1.47 \\
\hline
\end{tabular}


Table C-2. Presence/absence of Cultural Material and Mass Specific Sediment Susceptibility Scores for Shovel Tests at 41BR473

\begin{tabular}{|l|c|c|c|c|c|}
\hline & All Cases & $\begin{array}{c}\text { FCR } \\
\text { Present }\end{array}$ & $\begin{array}{c}\text { FCR } \\
\text { Absent }\end{array}$ & $\begin{array}{c}\text { Cipped Stone } \\
\text { Present }\end{array}$ & $\begin{array}{c}\text { Chipped Stone } \\
\text { Absent }\end{array}$ \\
\hline Number of Samples & 279 & 84 & 195 & 38 & 241 \\
\hline Mean Value & 48.3 & 56.9 & 44.6 & 55.2 & 47.2 \\
\hline Standard Deviation & 17.2 & 17.7 & 15.6 & 16.1 & 17.1 \\
\hline
\end{tabular}

\section{Results}

Table C-3 presents the results of the susceptibility analysis of the 30 samples collected at 41BR392, while Table C-4 presents the values for 41BR500. An examination of the MS values from 41BR392 will show that there is considerable variability both within a given test unit, and especially between TU 3 and TU 4. Note that the upper portion of TU 3 is dominated by high values, with a dramatic drop between roughly 53.5 and $58.5 \mathrm{cmbd}$, and a second drop after $73.5 \mathrm{cmbd}$. While it is unclear what the first drop may indicate, given the distribution of material within the deposits, the second drop corresponds to the bottom of the midden. Two peaks are present in the upper midden deposits, with the initial peak occurring at $13.5 \mathrm{cmbd}$ and a second peak at $53.5 \mathrm{cmbd}$. As discussed in Chapter 6, it is likely that these peaks correspond to different periods of more intensive use of the feature. For the outside unit, TU 4, the range of values is much more restricted and the magnitude of change in those values is relatively subtle. There is an increase, from 53.48 at $18.5 \mathrm{cmbd}$ to 61.15 at $28.5 \mathrm{cmbd}$, that is consistent with a buried surface occurring somewhere within this range, but the overall increase is such that the surface probably is not associated with significant cultural occupation.
For 41BR500 (Table C-4), there is also considerable variability present in the MS values, especially in those samples associated with the TUs 1, 2, and 3 excavation area. Low surface values are followed by a dramatic increase occurring in all three units between 15 and $25 \mathrm{cmbs}$. The lack of any consistency in exactly where that increase occurs may signal a fluctuating surface, or may simply be associated with the addition of cultural material to the sediment matrix. In TU 4, the pattern suggests a buried surface, probably at $20 \mathrm{cmbs}$, where a peak value of 84.91 was recorded. Below that depth, there is a gradual fall-off of values until values are at 50 at the bottom of the excavation. Below the $20 \mathrm{~cm}$ level, no clear surfaces are present. 
Table C-3. Sediment Susceptibility Samples from 41BR392

\begin{tabular}{|c|c|c|c|c|c|c|c|}
\hline Provenience & Sample \# & Weight (gr.) & Reading 1 & Reading 2 & Average & MS Value & cmbd \\
\hline TU1 & SS18 & 12.9 & 89.5 & 89.6 & 89.55 & 111.24 & 10.5 \\
\hline TU1 & SS17 & 13 & 101.2 & 102.6 & 101.90 & 125.03 & 15.5 \\
\hline TU1 & SS16 & 13 & 129.7 & 127.5 & 128.60 & 157.79 & 20.5 \\
\hline TU1 & SS15 & 12.8 & 73.9 & 74 & 73.95 & 93.02 & 25.5 \\
\hline TU1 & SS14 & 12.9 & 78.9 & 79 & 78.95 & 98.07 & 30.5 \\
\hline TU1 & SS13 & 12.9 & 140.1 & 139.1 & 139.60 & 173.42 & 35.5 \\
\hline TU1 & SS12 & 13.1 & 90.9 & 91 & 90.95 & 110.24 & 40.5 \\
\hline TU1 & SS11 & 12.9 & 86.5 & 86.3 & 86.40 & 107.33 & 45.5 \\
\hline TU1 & SS10 & 13.1 & 79.6 & 79.8 & 79.70 & 96.61 & 50.5 \\
\hline TU1 & SS09 & 12.8 & 83.3 & 83.8 & 83.55 & 105.09 & 55.5 \\
\hline TU1 & SS08 & 12.8 & 81 & 82 & 81.50 & 102.52 & 60.5 \\
\hline TU1 & SS07 & 13.1 & 103.5 & 104.4 & 103.95 & 126.00 & 65.5 \\
\hline TU1 & SS06 & 12.9 & 83.1 & 84.7 & 83.90 & 104.22 & 70.5 \\
\hline TU1 & SS05 & 13.1 & 101 & 101 & 101.00 & 122.42 & 75.5 \\
\hline TU1 & \begin{tabular}{|l|}
$\mathrm{SS} 04$ \\
\end{tabular} & 13.1 & 81.4 & 81.5 & 81.45 & 98.73 & 80.5 \\
\hline TU1 & \begin{tabular}{|l}
$\mathrm{SS} 03$ \\
\end{tabular} & 13.1 & 83.3 & 83.5 & 83.40 & 101.09 & 85.5 \\
\hline TU1 & \begin{tabular}{|l}
$\mathrm{SS} 02$ \\
\end{tabular} & 12.8 & 69.4 & 69.9 & 69.65 & 87.61 & 90.5 \\
\hline TU1 & \begin{tabular}{|l|} 
SS01 \\
\end{tabular} & 13 & 35.3 & 35 & 35.15 & 43.13 & 95.5 \\
\hline TU2 & SS19 & 12.9 & 73.8 & 73.8 & 73.80 & 91.68 & 10.5 \\
\hline TU2 & SS18 & 13.1 & 82.2 & 83.4 & 82.80 & 100.36 & 15.5 \\
\hline TU2 & \begin{tabular}{|l} 
SS17 \\
\end{tabular} & 12.9 & 84.2 & 84.3 & 84.25 & 104.66 & 20.5 \\
\hline TU2 & SS16 & 13.1 & 92.1 & 92.3 & 92.20 & 111.76 & 25.5 \\
\hline TU2 & SS15 & 13.1 & 87 & 88.2 & 87.60 & 106.18 & 30.5 \\
\hline TU2 & SS14 & 13.1 & 81.9 & 82.4 & 82.15 & 99.58 & 35.5 \\
\hline TU2 & SS13 & 13 & 87.3 & 87.6 & 87.45 & 107.30 & 40.5 \\
\hline TU2 & SS12 & 13.1 & 117.8 & 117.9 & 117.85 & 142.85 & 45.5 \\
\hline TU2 & \begin{tabular}{|l} 
SS11 \\
\end{tabular} & 12.9 & 73.2 & 74.2 & 73.70 & 91.55 & 50.5 \\
\hline TU2 & \begin{tabular}{|l|l} 
SS 10 \\
\end{tabular} & 12.8 & 85.9 & 86.1 & 86.00 & 108.18 & 55.5 \\
\hline TU2 & \begin{tabular}{|l} 
SSO9 \\
\end{tabular} & 13 & 72.6 & 71.6 & 72.10 & 88.47 & 60.5 \\
\hline TU2 & \begin{tabular}{|l} 
SS08 \\
\end{tabular} & 13.1 & 82.7 & 83.2 & 82.95 & 100.55 & 65.5 \\
\hline TU2 & \begin{tabular}{|l} 
SS07 \\
\end{tabular} & 13 & 92.4 & 92.2 & 92.30 & 113.25 & 70.5 \\
\hline TU2 & \begin{tabular}{|l|} 
SS06 \\
\end{tabular} & 13.1 & 79.4 & 80.2 & 79.80 & 96.73 & 75.5 \\
\hline TU2 & $\begin{array}{l}\text { SS05 } \\
\end{array}$ & 12.9 & 109.1 & 111.3 & 110.20 & 136.89 & 80.5 \\
\hline TU2 & \begin{tabular}{|l} 
SS04 \\
\end{tabular} & 12.9 & 53.7 & 52.4 & 53.05 & 65.90 & 85.5 \\
\hline TU2 & \begin{tabular}{|l}
$\mathrm{SS} 03$ \\
\end{tabular} & 13 & 27.7 & 28 & 27.85 & 34.17 & 90.5 \\
\hline TU2 & \begin{tabular}{|l|} 
SS02 \\
\end{tabular} & 12.8 & 27.1 & 27.1 & 27.10 & 34.09 & 95.5 \\
\hline TU2 & SS01 & 12.9 & 24.4 & 24.9 & 24.65 & 30.62 & 100.5 \\
\hline
\end{tabular}


Table C-3. continued...

\begin{tabular}{|c|c|c|c|c|c|c|c|}
\hline Provenience & Sample \# & Weight (gr.) & Reading 1 & Reading 2 & Average & MS Value & cmbd \\
\hline TU3 & SS19 & 13 & 85 & 86 & 85.50 & 104.91 & 8.5 \\
\hline TU3 & SS18 & 12.9 & 154.1 & 157.1 & 155.60 & 193.29 & 13.5 \\
\hline TU3 & SS17 & 13.1 & 90.9 & 91.4 & 91.15 & 110.48 & 18.5 \\
\hline TU3 & SS16 & 13.1 & 89.4 & 90.1 & 89.75 & 108.79 & 23.5 \\
\hline TU3 & SS15 & 12.7 & 72.3 & 72.2 & 72.25 & 92.04 & 28.5 \\
\hline TU3 & SS14 & 13.1 & 89.1 & 89.5 & 89.30 & 108.24 & 33.5 \\
\hline TU3 & SS13 & 13 & 82.3 & 82.8 & 82.55 & 101.29 & 38.5 \\
\hline TU3 & SS12 & 12.9 & 83.2 & 83.4 & 83.30 & 103.48 & 43.5 \\
\hline TU3 & SS11 & 12.9 & 107 & 107.1 & 107.05 & 132.98 & 48.5 \\
\hline TU3 & $\mathrm{SS} 10$ & 13 & 173 & 173.4 & 173.20 & 212.52 & 53.5 \\
\hline TU3 & SS09 & 12.9 & 66.8 & 67.9 & 67.35 & 83.66 & 58.5 \\
\hline TU3 & SS08 & 12.9 & 52.6 & 52.1 & 52.35 & 65.03 & 63.5 \\
\hline TU3 & SS07 & 13.1 & 44.8 & 45.4 & 45.10 & 54.67 & 68.5 \\
\hline TU3 & SS06 & 13 & 56.7 & 57.5 & 57.10 & 70.06 & 73.5 \\
\hline TU3 & $\mathrm{SS} 05$ & 12.9 & 29.8 & 30.8 & 30.30 & 37.64 & 78.5 \\
\hline TU3 & SS04 & 13 & 28.3 & 28.4 & 28.35 & 34.79 & 83.5 \\
\hline TU3 & $\mathrm{SS} 03$ & 10.1 & 17.4 & 17.8 & 17.60 & 33.52 & 88.5 \\
\hline TU3 & \begin{tabular}{|l|}
$\mathrm{SS} 02$ \\
\end{tabular} & 13 & 20.6 & 21.1 & 20.85 & 25.58 & 93.5 \\
\hline TU3 & SS01 & 13 & 31.5 & 32.2 & 31.85 & 39.08 & 98.5 \\
\hline TU4 & \begin{tabular}{|l} 
SS11 \\
\end{tabular} & 13 & 45.6 & 45.6 & 45.60 & 55.95 & 8.5 \\
\hline TU4 & SS10 & 13.1 & 43.4 & 43.6 & 43.50 & 52.73 & 13.5 \\
\hline TU4 & SS09 & 12.9 & 42.2 & 42.3 & 42.25 & 52.48 & 18.5 \\
\hline TU4 & SS08 & 13.1 & 47.2 & 48 & 47.60 & 57.70 & 23.5 \\
\hline TU4 & $\mathrm{SS} 07$ & 13.1 & 50.6 & 50.3 & 50.45 & 61.15 & 28.5 \\
\hline TU4 & SS06 & 13 & 42 & 42 & 42.00 & 51.53 & 33.5 \\
\hline TU4 & $\mathrm{SS} 05$ & 13.1 & 44 & 44.1 & 44.05 & 53.39 & 38.5 \\
\hline TU4 & $\mathrm{SS} 04$ & 13 & 41.1 & 40.2 & 40.65 & 49.88 & 43.5 \\
\hline TU4 & $\mathrm{SS} 03$ & 13.1 & 37 & 37.1 & 37.05 & 44.91 & 48.5 \\
\hline TU4 & $\mathrm{SS} 02$ & 12.9 & 34.1 & 34.1 & 34.10 & 42.36 & 53.5 \\
\hline TU4 & $\mathrm{SS} 01$ & 13 & 32.8 & 32.6 & 32.70 & 40.12 & 58.5 \\
\hline
\end{tabular}


Table C-4. Sediment Susceptibility Samples from 41BR500

\begin{tabular}{|c|c|c|c|c|c|c|c|}
\hline Provenience & Sample \# & Weight (gr.) & Reading 1 & Reading 2 & Average & MS Value & cmbs \\
\hline TU1 & SS05 & 13.1 & 33.8 & 33.4 & 33.60 & 40.73 & 5 \\
\hline TU1 & SS04 & 13 & 64.2 & 65.2 & 64.70 & 79.39 & 10 \\
\hline TU1 & $\mathrm{SS} 03$ & 13.1 & 81.1 & 80.4 & 80.75 & 97.88 & 15 \\
\hline TU1 & $\mathrm{SS} 02$ & 12.9 & 82.9 & 82 & 82.45 & 102.42 & 20 \\
\hline TU1 & SS01 & 13 & 86.2 & 86.6 & 86.40 & 106.01 & 25 \\
\hline TU2 & SS07 & 12.9 & 39.7 & 41.3 & 40.50 & 50.31 & 5 \\
\hline TU2 & SS06 & 13 & 51.5 & 51.6 & 51.55 & 63.25 & 10 \\
\hline TU2 & SS05 & 13 & 65.5 & 66.7 & 66.10 & 81.10 & 15 \\
\hline TU2 & SS04 & 13.1 & 72.7 & 74.1 & 73.40 & 88.97 & 20 \\
\hline TU2 & $\mathrm{SS} 03$ & 13 & 97.9 & 101.1 & 99.50 & 122.09 & 25 \\
\hline TU2 & SS02 & 13 & 78.4 & 77.9 & 78.15 & 95.89 & 30 \\
\hline TU2 & SS01 & 12.9 & 75.3 & 74 & 74.65 & 92.73 & 35 \\
\hline TU3 & SS07 & 13 & 40.7 & 40.8 & 40.75 & 50.00 & 5 \\
\hline TU3 & SS06 & 12.9 & 39 & 40.1 & 39.55 & 49.13 & 10 \\
\hline TU3 & SS05 & 13.1 & 35.6 & 34.5 & 35.05 & 42.48 & 15 \\
\hline TU3 & SS04 & 13 & 49.8 & 49.9 & 49.85 & 61.17 & 20 \\
\hline TU3 & $\mathrm{SS} 03$ & 12.9 & 105.9 & 108.3 & 107.10 & 133.04 & 25 \\
\hline TU3 & $\mathrm{SS} 02$ & 12.9 & 72.9 & 73.1 & 73.00 & 90.68 & 30 \\
\hline TU3 & SS01 & 13.1 & 89.6 & 90.5 & 90.05 & 109.15 & 35 \\
\hline TU4 & SS15 & 12.8 & 53.8 & 53.6 & 53.70 & 67.55 & 5 \\
\hline TU4 & SS14 & 12.9 & 60.1 & 60.6 & 60.35 & 74.97 & 10 \\
\hline TU4 & SS13 & 13 & 64.5 & 65 & 64.75 & 79.45 & 15 \\
\hline TU4 & SS12 & 12.9 & 69 & 67.7 & 68.35 & 84.91 & 20 \\
\hline TU4 & SS11 & 12.8 & 59.8 & 60.2 & 60.00 & 75.47 & 25 \\
\hline TU4 & $\mathrm{SS} 10$ & 13.1 & 57.6 & 58.3 & 57.95 & 70.24 & 30 \\
\hline TU4 & SS09 & 13 & 57.7 & 57.1 & 57.40 & 70.43 & 35 \\
\hline TU4 & SS08 & 13 & 53.2 & 52 & 52.60 & 64.54 & 40 \\
\hline TU4 & SS07 & 12.1 & 51.3 & 51 & 51.15 & 70.55 & 45 \\
\hline TU4 & SS06 & 11.4 & 41.1 & 40.7 & 40.90 & 62.44 & 50 \\
\hline TU4 & SS05 & 11.7 & 41.3 & 41.2 & 41.25 & 60.22 & 55 \\
\hline TU4 & $\mathrm{SS} 04$ & 12.1 & 41.4 & 41.4 & 41.40 & 57.10 & 60 \\
\hline TU4 & $\mathrm{SS} 03$ & 12.8 & 47 & 46.9 & 46.95 & 59.06 & 65 \\
\hline TU4 & $\mathrm{SS} 02$ & 13.1 & 46.7 & 46.1 & 46.40 & 56.24 & 70 \\
\hline TU4 & SS01 & 13 & 40.4 & 41.1 & 40.75 & 50.00 & 75 \\
\hline
\end{tabular}




\section{References Cited}

Collins, M. B., W. A. Gose, and S. Shaw

1994 Preliminary Geomorphological Findings at Dust and Nearby Caves. Journal of Alabama Archaeology 40:35-56.

Dearing, J.

1999 Environmental Magnetic Susceptibility. Chi Publishing, Kenilworth, England.

Gose, W. A., and D. L. Nickels

2001 Archaeomagnetic and Magnetic Susceptibility Analyses. In Test Excavations at the Culebra Creek Site, 41BX126, Bexar County, Texas, by D. L. Nickels, C. B. Bousman, J. D. Leach, and D. A. Cargill, pp. 204-214. Archaeological Survey Report, No. 265, Center for Archaeological Research, The University of Texas at San Antonio. Archeology Studies Program, Report 3, Environmental Affairs Division, Texas Department of Transportation, Austin.

McClean, R. G., and W. F. Kean

1993 Contributions of Wood Ash Magnetism to Archeomagnetic Properties of Fire Pits and Hearths. Earth and Planetary Science Letters 119:387-394.

Reynolds, R. L., and J. W. King

1995 Magnetic Records of Climate Change. U.S. National Report to I.U.G.G., 1991-1994. American Geophysical Union. $<$ http://www.agu.ong/revgeophys/reyno100/reyno100.html > Accessed April 2001.

Singer, M. J., and P. Fine

1989 Pedogenic Factors Affecting Magnetic Susceptibility of Northern California Soils. Soil Science of America Journal 53:1119-1127. 


\section{Appendix D}

\section{Geoarchaeological Investigations}




\title{
Appendix D: Geoarchaeological Investigations
}

\author{
Russell D. Greaves
}

\section{Introduction}

Geoarchaeological investigations were performed at three of the four sites investigated during this testing project at Camp Bowie. Prehistoric components of 41BR392, 41BR500, and 41BR522 were examined through profiling and soil descriptions of excavation units. Site 41BR471 was not evaluated because access to this portion of Camp Bowie was restricted during the period of geomorphic investigation. Preliminary observations were made on this site previously during initial testing at this location (Greaves 2002:26-30). Geoarchaeological examinations were performed to characterize the geomorphic setting, determine past site formation dynamics, and assess the potential depositional integrity of these archaeological deposits. This work was part of the effort to characterize these sites and determine their significance and potential eligibility as SAL or NRHP properties.

All of the sites examined are in the northern portion of Camp Bowie (see Figure 2-2). Sites 41BR392 and 41BR522 were selected for testing because of the presence of burned rock middens. Site 41BR500 was selected because of the possible presence of a burned rock hearth. All are situated on alluvial soils in relative proximity to bedrock outcrops. $41 \mathrm{BR} 471$ did not contain any identified feature and is much more distant from the Cretaceous ridge bedrock. This site was tested because of the relatively high density of materials encountered during testing. There is apparently little subsurface archaeological component (Greaves 2002) but it contained a surface assemblage that may represent a shortterm use location. All sites examined are prehistoric open lithic scatters with features. 41BR392 contains a historic component that was previously described (Wormser and Sullo-Prewitt 2001) but not evaluated during this work effort.

Sites 41BR392 and 41BR522 are located on the western margin of the floodplain of Pecan Bayou. Both of these sites are situated on deep alluvium directly adjacent to the Cretaceous upland ridge. This upland area is part of the Cretaceous plateau made of Travis Peak formation conglomerates, sandstone, and limestone. 41BR392 is approximately $250 \mathrm{~m}$ southeast of the bedrock ridge. $41 \mathrm{BR} 522$ is situated at the toe of alluvial fan deposits of coarse sandstone bedrock where it meets the level alluvial deposits. 41BR500 is in the terrace deposits of the Lewis Creek drainage basin, a third-fifth order tributary of Pecan
Bayou. It is situated approximately $50 \mathrm{~m}$ northeast of exposed Cretaceous bedrock. The area adjacent to 41BR392 and 41BR522 is currently used as a tank range. It has been impacted by road construction, heavy vehicular traffic, brush clearing, and firing range use. 41 BR500 is located at the margin of a former agricultural field and two-track road. Plowing has significantly disturbed deposits associated with this site and testing was limited to a narrow margin of floodplain adjacent to the uplands.

The soils of the Pecan Bayou floodplain in the portion of Camp Bowie where 41BR392, 41BR471, and 41BR522 are situated are primarily Frio-Surnev-Winters deep loamy alluvial soils. Sites 41BR392 and 41BR522 are in deep Nukrum silty clay valley soils (Clower 1980). This is the portion of the alluvial plain farthest from the modern channel, adjacent to uplands of Cretaceous formation mantled by thin Bolar series soils. The Lewis Creek floodplain, where 41BR500 is located, contains LeeraySagerton-Nukrum deep loamy soils. This site is at an interface between deep Abilene clay (Clower 1980) of the Lewis Creek valley alluvium and deep Leeray clay soils (Clower 1980) derived from the Cretaceous uplands. These areas of alluvial plain are subject to flooding and vertical sedimentary accretion. Most of the floodplain is between 1,290-1,300 ft (393-396 m) AMSL although these two sites are situated on slightly higher areas $(1,310-1,330 \mathrm{ft}$ [399$405 \mathrm{~m}$ ] AMSL) where there is interfingering of the floodplain deposits and alluvial fan materials from the Cretaceous upland (i.e., Waters 1992:Figure 2.14). The vegetation of this area is dominated by grassland with localized broken woodland of live oak (Quercus virginiana), mesquite (Prosopis sp.), and ashe juniper (Juniperus ashei). Localized impacts from mechanical brush clearing, road construction and maintenance, ranching, and past agricultural practices have initiated erosion of significant portions of this landscape. Road maintenance, brush clearing, cattle grazing, and military activities continue to impact these areas.

\section{Methods}

Geoarchaeological examination was made of test unit excavations on 41BR392, 41BR500, and 41BR522. No backhoe trenches or off-site control soil pits were excavated. A profile was drawn for one face of each test unit. Soil descriptions were completed for every identified 
sedimentary and soil horizon from each profile. Geoarchaeological investigation used standard soil profiling methods employed in soil science (Soil Survey Staff 1975: 459-481, 1993:117-168, 172-180, 184-193). Observations of the geomorphic setting were made during this investigation. Color slide photographs were taken of all profiles. Field soil observations included soil texture, consistence (wet and dry), presence and morphology of clay films, grain coatings, structure, abundance and size of roots, abundance and size of pores, $\mathrm{HCl}$ (hydrochloric acid) reaction, horizon boundaries, and Munsell colors (wet and dry). These attributes permit designation of the soil and sedimentary horizons in standard soil nomenclature (Soil Survey Staff 1993:117-135). The abundance and size of clasts was also recorded.

\section{Geoarchaeological Investigation Results}

\section{BR392}

41BR392 is located within the current floodplain of Pecan Bayou. It is situated on Nukrum silty clay at the western margin of the alluvial plain near an ephemeral drainage of the Cretaceous uplands. The uplands are Doudle-Real Association hilly soils, with alluvial fan sediments of Pedernales fine sandy loam and Throck Association materials. This site consists of a relatively large burned rock midden deposit and recent historic Euro-American architectural remains (see Figure 6-2). The midden is approximately $13 \mathrm{~m}$ north-south by $12 \mathrm{~m}$ east-west and is maximally $50 \mathrm{~cm}$ higher than the surrounding terrace tread surface. A single Bulverde point was recovered from the site surface near a historic period masonry wall on the northern side of the midden. This early Late Archaic diagnostic is not associated with other artifacts. The site was originally recorded only as a historic site (Wormser and Sullo-Prewitt 2001). The prehistoric component was recognized later during subsurface testing by Mauldin and Broehm (2001). A historic masonry wall was constructed on the northern side of the site and is contiguous with the northwestern margin of the midden feature. The midden feature on this site is not as well defined as that investigated at 41BR522. There is additional evidence of local mechanical disturbance from the construction of an artificial bermed ridge approximately $8 \mathrm{~m}$ west of TU 3 .

Three profiles were examined at this site. A complete description was performed on the western wall of TU 4, located away from the feature on the terrace surface.
Abbreviated descriptions were done for units within the burned rock midden feature. Because the midden fill is an anthropic epipedon with relatively minor differences throughout the disturbed fill sequence, only a single area of the feature fill was described. Undisturbed sediments or soils underlying the midden deposits were described stratigraphically. Within the burned rock midden on this site, the western walls of TUs 1 and 2 were profiled and the western wall of TU 3 also was described.

TU 4 was located approximately $10 \mathrm{~m}$ east of TUs 1 and 2 in the center of the burned rock midden feature. This unit is located on a lower, undisturbed terrace tread surface. TU 4 represents a complete profile of soils on this portion of the terrace deposits. This profile is $60 \mathrm{~cm}$ deep. The profile of this unit is presented in Figure D-1 and the soil description is given in Table D-1. There is a thick A horizon in this unit $(22-25 \mathrm{~cm})$ consisting of three distinguishable subdivisions. A concentration of clasts is present at the contact between the $\mathrm{A} 3$ and $\mathrm{AB}$ horizons. The $\mathrm{AB}$ horizon is $18-20 \mathrm{~cm}$ thick and is physically separated from the recent sedimentation forming the modern A horizons by these clasts. The highest density of lithics from this unit was recovered between 20 $30 \mathrm{cmbs}$, approximately where the clast concentration is in the profile. Rock at the top of the $\mathrm{AB}$ soil is probably derived from the burned rock midden to the west and marks the approximate prehistoric surface at the time of the occupation of this site. This horizon represents the A horizon at the time of the archaeological occupation that is now developing $\mathrm{B}$ horizon characteristics. There is a greater accumulation of clay in the AB than noted in the A3 soil. The A2, A3, and

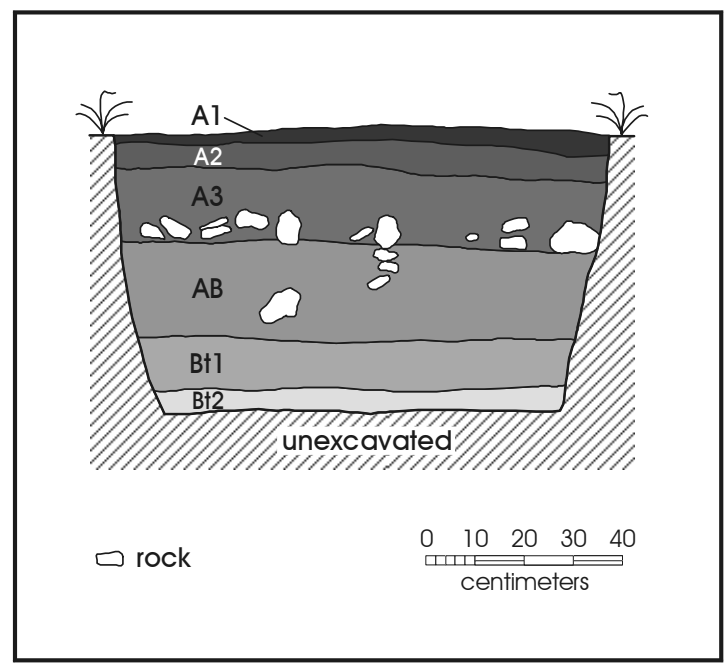

Figure D-1. Soil profile of Test Unit 4 (west wall) at $41 B R 392$. 


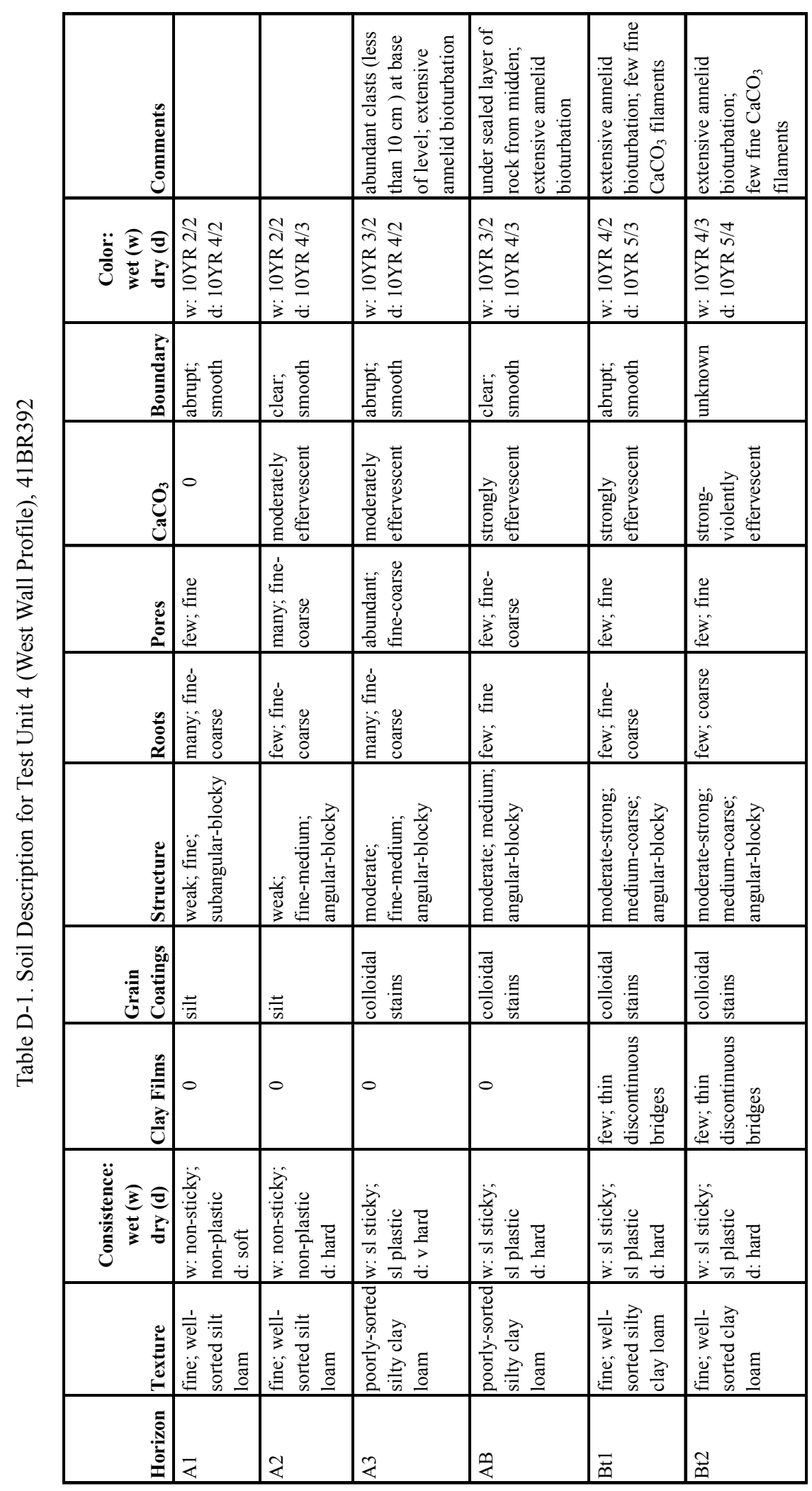


$\mathrm{AB}$ units are slightly calcareous. $\mathrm{A} 2$ and $\mathrm{A} 3$ exhibited moderate effervescence following application of $\mathrm{HCl}$. The $\mathrm{AB}$ is strongly effervescent as is the $\mathrm{Bt} 1$ horizon. Underneath the $\mathrm{AB}$ are two $\mathrm{Bt}$ horizons. These exhibit greater soil development, clay accumulation, and thin, discontinuous clay films. The $\mathrm{Bt}$ horizons contain few, fine $\mathrm{CaCO}_{3}$ filaments and have strong to violent effervescence. There is significant annelid bioturbation evident in the $\mathrm{A} 3, \mathrm{AB}$, $\mathrm{Bt} 1$, and Bt2 soils. TU 4 is situated on the same surface as TU 5 , located approximately $14 \mathrm{~m}$ south of TU 4 . The profile of TU 5 was briefly examined and was essentially identical to TU 4.

The other two profiles examined at this site are from excavations within the burned rock midden. TUs 1 and 2 are contiguous 1-x-1-m excavations in the center of this feature. Approximately $95 \mathrm{~cm}$ of deposits were exposed in these test units. The profile of the western wall is shown in Figure D-2 and the soil description is presented in Table D-2. The upper $80-93 \mathrm{~cm}$ represents midden fill that is black-very dark gray (7.5YR2.5/1, wet; 10YR3/1, dry) and contains abundant imbricated fire-cracked rock. A profile of this midden deposit is provided in Figure 6-4 (feature profile). No stratigraphic separations were defined within this massive unit of very poorly sorted silt loam. Some differences in the amount of rock visible in the profile are distinguished in Figure 6-4, but they are not associated with evidence for distinct depositional units. Gross sedimentary characteristics could not identify any cultural or natural taphonomic events in this feature. There is a very slight increase in carbonate from the top of the midden fill to the base. The lower boundary of the fill represents an unconformity with the underlying Bt soils. There are several flat-lying rocks at the southern end of this profile that are associated with the abrupt, smooth contact of the midden fill and the undisturbed argillic soil. TU 2 exhibits 15-17 $\mathrm{cm}$ of exposed Bt soil under the midden and TU 1 contains $2-11 \mathrm{~cm}$ of $2 \mathrm{Bt}$ horizon sediments. Although expressed at the same elevation, the $2 \mathrm{Bt}$ materials in TU 1 are different than the Bt soil in TU 2. There are abundant gravel clasts (5 $\mathrm{cm}$ or less in size) within the $2 \mathrm{Bt}$ horizon and none in the Bt. The source of these clasts is probably not alluvial deposition from Pecan Bayou but gravels weathered out of the Travis Peak conglomerates and transported downslope by alluvial and colluvial movement.

The profile of TU 3 (Figure D-3, Table D-3) sampled a portion of the midden approximately $5 \mathrm{~m}$ south of TU 2 , the southernmost of the 1-x-2-m excavation at the feature center. This unit was $100 \mathrm{~cm}$ deep. TU 3 samples the southern margin of the burned rock midden. Approximately $70 \mathrm{~cm}$ of midden material was present in this profile of the west wall. This poorly sorted silt loam with abundant fire-cracked rock and black, charcoal stained sediment (10YR2/1, wet; 7.5YR2.5/1, dry) rests unconformably on top of Bt horizons. Concentrations of fire-cracked rock are present within the

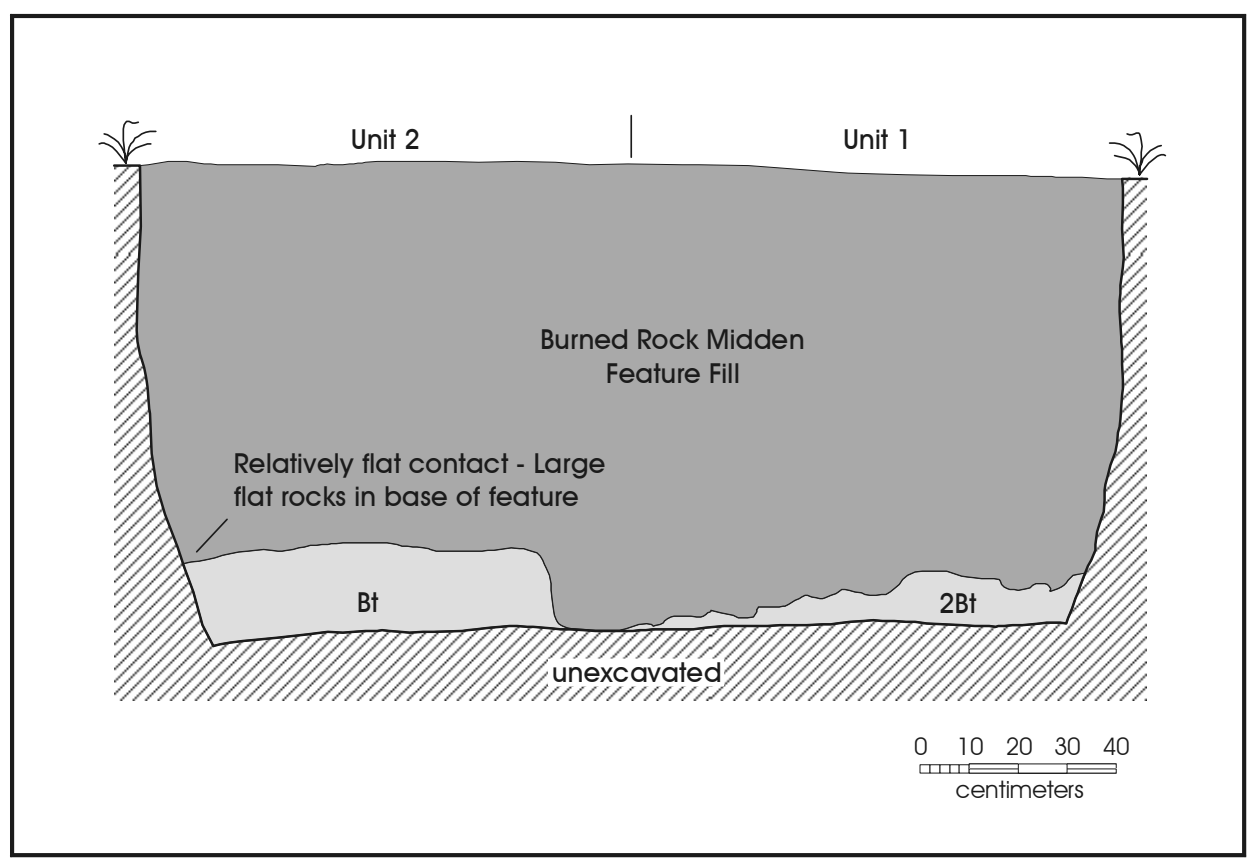

Figure D-2. Soil profile of Test Units 1 and 2 (west wall) at 41 BR392. 


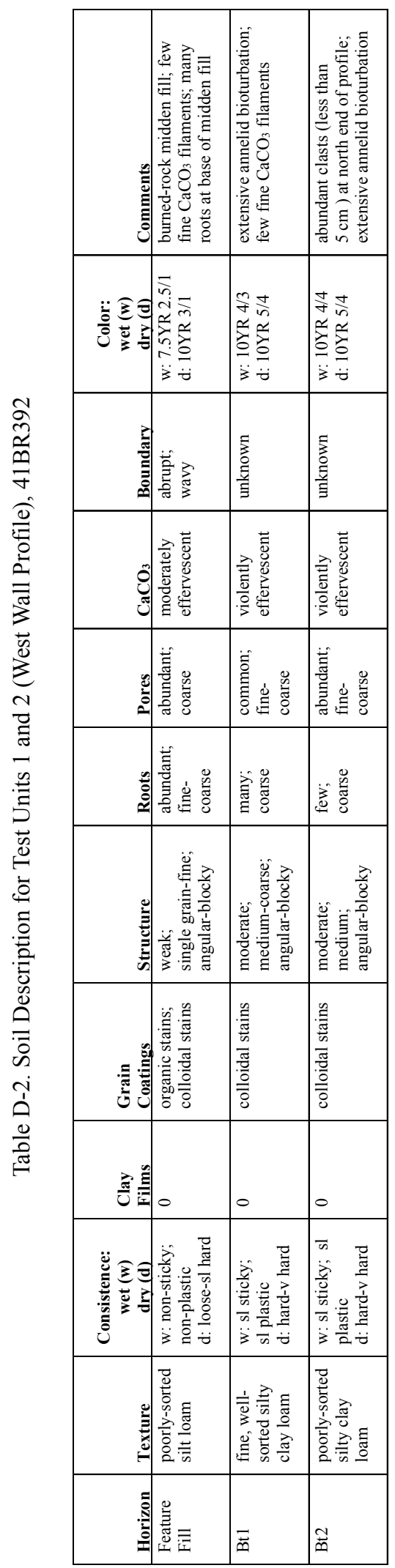


middle of this deposit (approximately 20-40 cmbs), but it is unclear whether they represent accumulations that can be associated with particular use events of this feature. A few larger rocks are present at the base of the midden deposit contact with the underlying Bt1 horizon. The midden fill is slightly calcareous but does not exhibit an increase in carbonate content from top to bottom. There is slightly less $\mathrm{CaCO}_{3}$ in the uppermost portion of the fill and a maximum presence in the middle. Both Bt horizons are calcareous. There is slightly more clay accumulation in the $\mathrm{Bt} 2$ horizon than in the Bt1 horizon.

\section{$41 B R 500$}

41BR500 is a moderately sized archaeological site on the level floodplain of Lewis Creek (see Figure 8-1) The channel of Lewis Creek is located approximately $400 \mathrm{~m}$ east of the site. This site is located at the western margin of the Lewis Creek alluvium. 41BR500 is situated on Abilene clay and Leeray clay soils. The immediately adjacent upland slope consists of Bonti-Throck Association soils and Doudle-Real Association soils that dominate the high Cretaceous surface. Alluvial fan deposits of an ephemeral drainage northwest of the site are Pedernales fine sandy loam and Throck Association soils. There is extensive plowing disturbance to the north and east of the area tested, showing pronounced berms and swales. The identified intact site area is restricted to a narrow margin west of the plowing disturbance approximately $160 \mathrm{~m}$ northwest-southeast and 16-24 m southwest-northeast. Debitage is visible in the plowed area between the tested portion of the site and the two-track road. Bedrock outcrops on a gentle slope mantled with colluvium approximately $20 \mathrm{~m}$ southwest of the test units. This site was initially identified through systematic shovel testing and analysis of sediment susceptibility samples (Mauldin and Broehm 2001:18-21). Two Darl points and one Pedernales point were recovered during the initial testing and suggest a Late Archaic date for this site. A rock accumulation that may be a feature was investigated with three contiguous 1-X-1-m test units (TUs 1-3). Two profiles were drawn and described on this site (Figures D-4 and D-5, Tables D-4 and D-5). The western wall of TUs 1 and 3 was profiled. This is a shallow profile. TU 3 is $30 \mathrm{~cm}$ deep and TU 1 is maximally $25 \mathrm{~cm}$ in depth. The west wall of these two units presented the greatest exposure of the soils within this possible feature. TU 2, on the east side of TU 1, was not profiled and provided only a very shallow exposure. These three contiguous 1-x-1-m units were excavated in an area representing a rock concentration that was suspected to be a cultural feature. Abundant rock within the upper soils suggested the

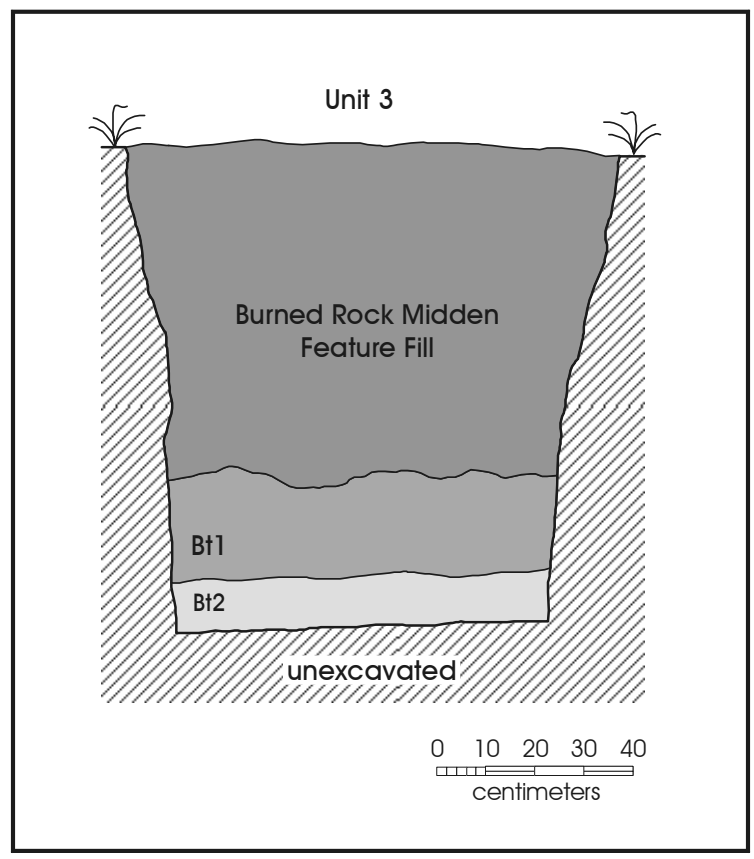

Figure D-3. Soil profile of Test Unit 3 (west wall) at $41 B R 392$.

possibility that a small, dispersed burned rock feature is present at this location. The eastern wall of TU 4 also was examined and described. TU 4 is maximally $64 \mathrm{~cm}$ deep and provides the most complete view of soils at this site.

The west wall of TUs 1 and 3 presents a shallow profile (Figure D-4) through a rock concentration that was interpreted in the field as a possible feature. Soil description (Table D-4) identified an A-Bt sequence on top of what may be an older $2 \mathrm{Bt}$ soil. The A horizons are $8-9 \mathrm{~cm}$ thick. Both $\mathrm{A} 1$ and $\mathrm{A} 2$ are silt loams. The A1 is a thin $(2 \mathrm{~cm})$, recent soil that is weakly developed. A2 contains some clasts and exhibits strong structure. The Bt horizon is a silty clay loam with abundant clasts (10 cm or less). Most of the clasts are present at the contact between the Bt and $2 \mathrm{Bt}$ soils. The $2 \mathrm{Bt}$ soil is clay and appears much more developed than the $\mathrm{Bt}$. None of the soils in this profile exhibited any $\mathrm{CaCO}_{3}$. The presence of numerous large clasts at the boundary between these two argillic units suggests these rocks have accumulated on an older soil surface represented by the top of the $2 \mathrm{Bt}$. Although this rock was recorded as a feature, the profile contained no evidence of charcoal or artifact concentrations that would suggest that this rock accumulation is associated with evidence of focused cultural activities. There is no evidence of rubification of the soil underneath the rock accumulation. The rocks are a mixture 


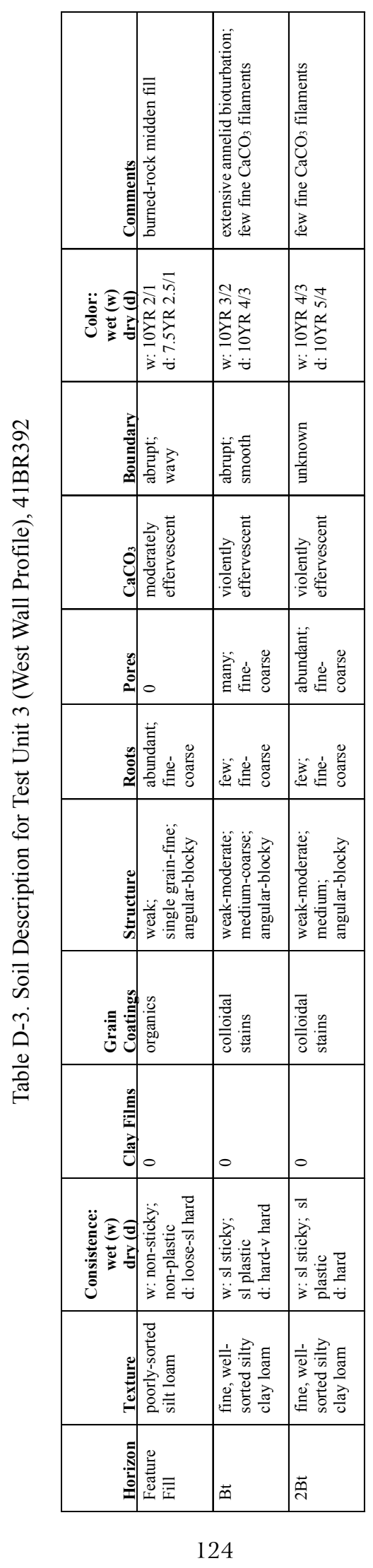




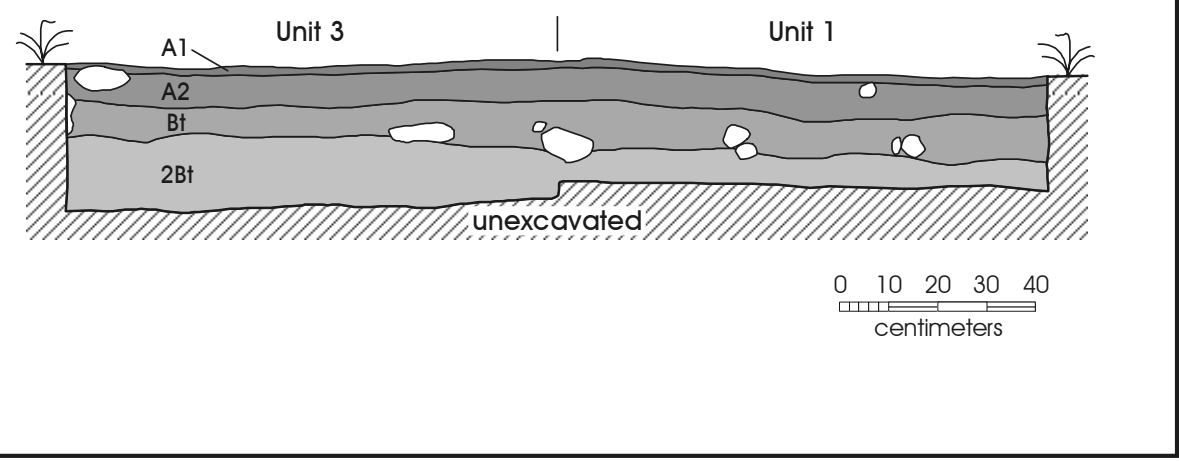

Figure D-4. Soil profile of Test Units 1 and 3 (west wall) at $41 B R 500$.

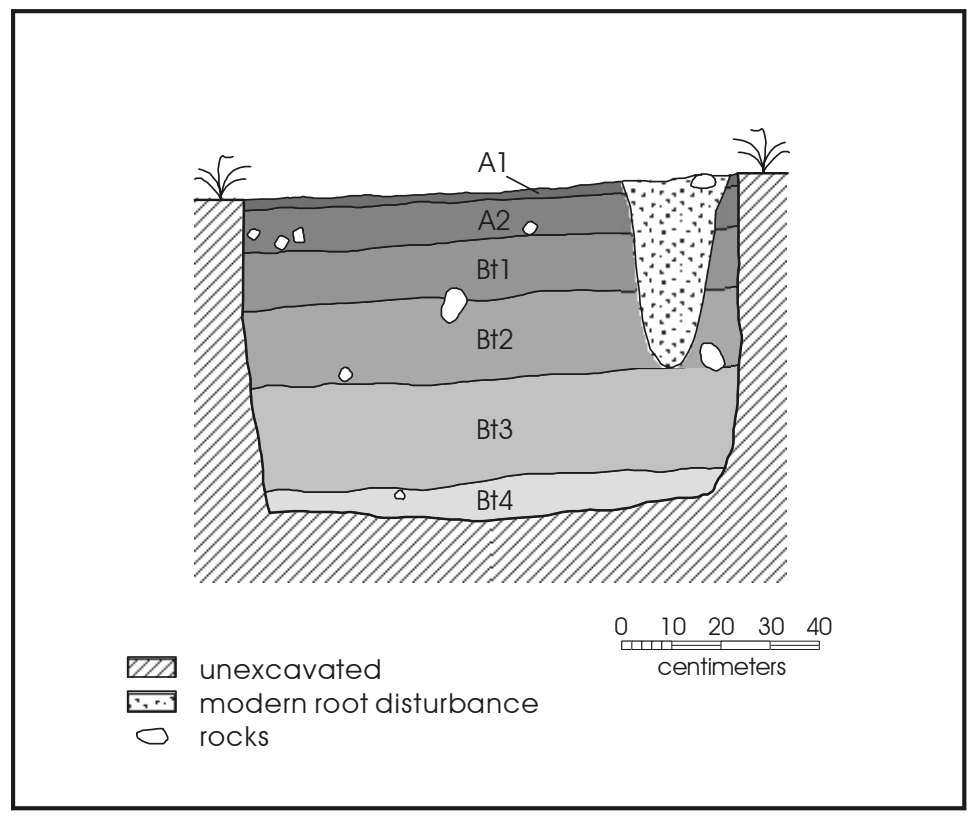

Figure D-5. Soil profile of Test Unit 4 (east wall) at 41 BR500.

of fire-altered rock and natural clasts. This may be an accumulation of clasts that include fire-cracked rock but does not indicate a feature location.

The eastern wall of TU 4 was profiled (Figure D-5) and described (Table D-5). TU 4 was located approximately 31 $\mathrm{m}$ southeast of TU 3. This unit was deeper than the excavation block of TUs 1-3 and provided a more complete view of the soils at this site. The soils are similar to those seen in TU 1 and TU 3. There is a thin A horizon $(11 \mathrm{~cm})$ overlying a sequence of Bt soils. The A2 horizon contains abundant clasts ( $4 \mathrm{~cm}$ or less in size). Several of the larger clasts are associated with the lowest portion of the A2 soil. The source of clasts may be from colluvial movement of sediments from the uplands to the south. One Nolan dart point was recovered within the $\mathrm{Bt} 1$ horizon or upper half of the Bt2. This point is considered a Middle Archaic diagnostic. Archaeological artifacts were most common in 

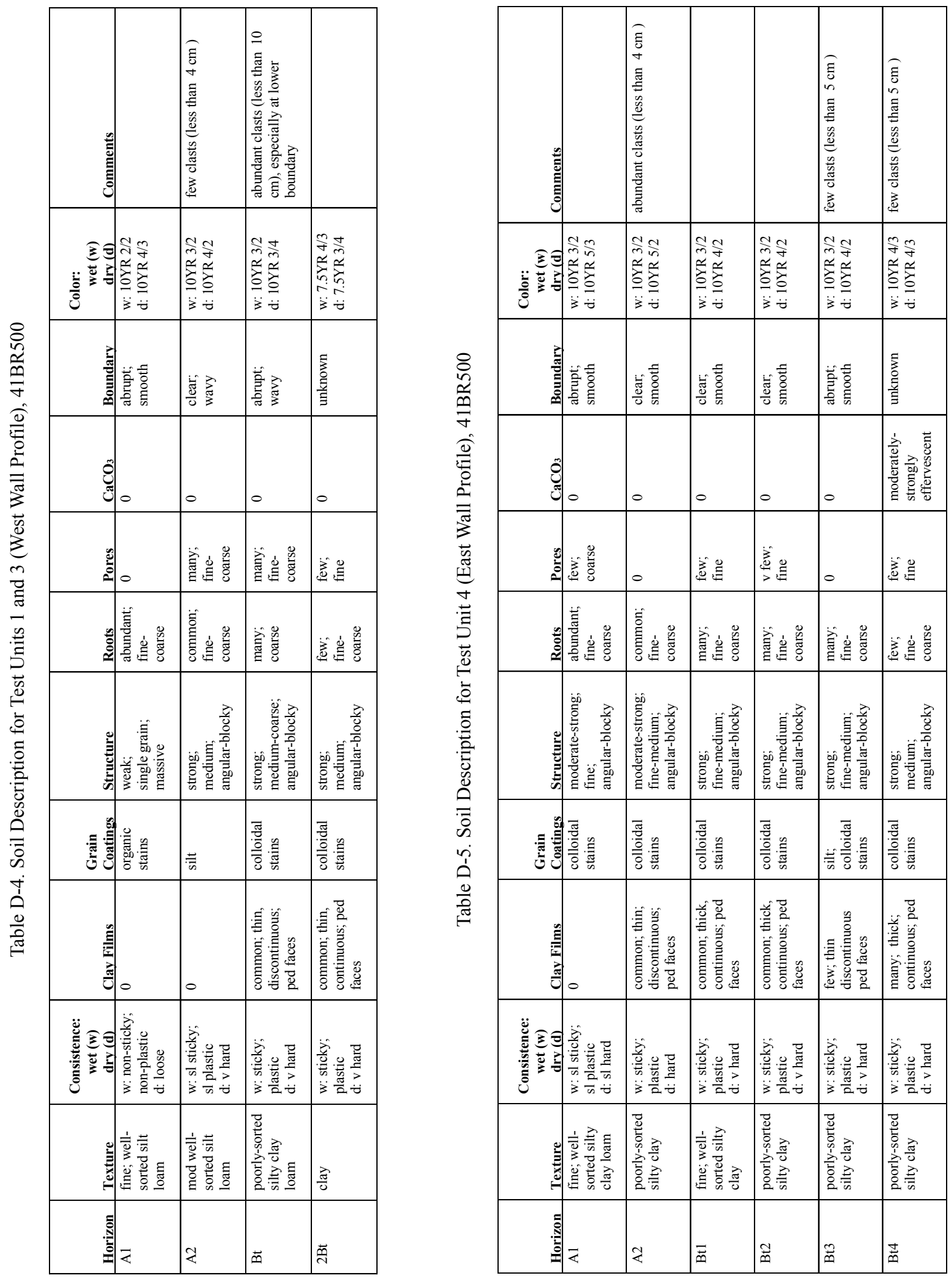
the upper $30 \mathrm{~cm}$ of this unit, especially from the base of the A2 to the base of the Bt1 horizon. There are no unconformities in this profile; however, the Bt4 horizon does appear to be older than the overlying soils. The Bt4 horizon produced moderate-strong effervescence when exposed to $\mathrm{HCl}$. There was no carbonate in any of the other horizons. This suggests that $\mathrm{Bt} 4$ is an older soil unit that may not be genetically related to the other Bt horizons. The depositional regime may be unrelated to the more recent alluvium from Lewis Creek, however, the parent material appears to be the same as the upper solum.

\section{BR522}

41BR522 is a small archaeological site (see Figure 9-2). It consists of one burned rock midden and a minimal association of lithic debris downslope of the feature. 41BR522 is located at the southeastern margin of alluvial fan deposits of colluvial material and the western boundary of the recent Pecan Bayou alluvial plain. This site is located at the margin of the Throck Association upland soils and the Nukrum soils of the alluvial plain. The site is mostly on Nukrum silty clay. The northwestern margin of the burned rock midden is on the toe of alluvial fan sediments of Throck Association soils from the higher Cretaceous surfaces. The upland area, adjacent alluvial fan, or colluvial slopes are the apparent source of rock used in this feature. There is a recent fence line, corral, and two-track road adjacent to the site. Despite this evidence of ranching activities, there do not appear to be significant impacts to the site. There is a shallow, incised drainage along the southwestern side of the midden, but few artifacts were visible in this ephemeral drainage and it has not significantly affected the midden feature.

Two profiles were examined and described at 41BR522. A complete soil description was recorded for the western wall of TU 6. This unit offers information about the terrace surface where the feature was constructed. Profiling of a segment of the burned rock midden on this site involved the western wall of TUs 3 and 4 . At the time of field recording, complete excavation through the midden fill to intact underlying soil had not yet been accomplished. This examination profiled only the southernmost portion of this feature where excavation had exposed soil below the midden fill. A complete profile drawing of the excavations into this burned rock feature was made following the geoarchaeological recording (Figure 9-4, TUs 1-5 profile). Because excavation terminated just below the contact of the midden fill with the underlying soil, there is only a minimal exposure of sediments underneath the anthropic disturbed feature deposits.

The profile and description of TU 6 (Figure D-6 and Table D-6) offers a controlled view of the local soils and sediments of the floodplain margin where the burned rock midden is located. This unit contained a very thin A horizon $(2-4 \mathrm{~cm})$ of sandy loam overlying two poorly sorted C horizon sandy loam sedimentary units. This A horizon is very recent. The two $\mathrm{C}$ horizons extend approximately $11-15 \mathrm{~cm}$ below the A horizon. These poorly sorted sandy loam units are probably colluvial deposition from the adjacent uplands approximately $22 \mathrm{~m}$ to the northwest. Both of these units are very sandy and show no soil development. The presence of a shallow, ephemeral drainage on the southwestern side of the feature is evidence of periodic alluvial flow and deposition affecting the area where TU 6 is located. The poor sorting indicates that colluvial and alluvial slopewash is the most likely source of these units. They do not appear well-sorted enough to represent stream deposits. At this portion of the floodplain, overbank deposits from Pecan Bayou or the ephemeral drainage east of this site would contain mostly fines. The mixed gravels and sands are consistent with colluvial material from the adjacent uplands. The $\mathrm{C} 2$ horizon is sandier than the $\mathrm{C} 1$ and also has more clasts than the $\mathrm{C} 1$. There is significant concentration of larger clasts $(2 \mathrm{~cm}$ or less in size) at the base of this level with smaller gravels at the upper boundary ( $1 \mathrm{~cm}$ or less in size). The clasts and sand in C2 suggest a fining upward depositional sequence. The highest density of artifacts from this unit were recovered from the $\mathrm{C} 2$ and upper $10 \mathrm{~cm}$ of the Bt1 horizon. These may be deposited as soil clasts, or they may indicate that this is the approximate land surface at the time of the prehistoric occupation. These recent

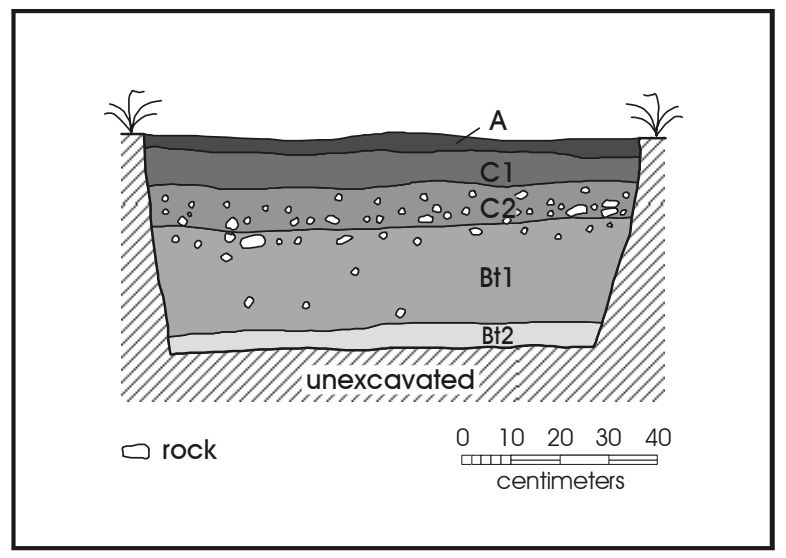

Figure D-6. Soil profile of Test Unit 6 (west wall) at 41BR522. 


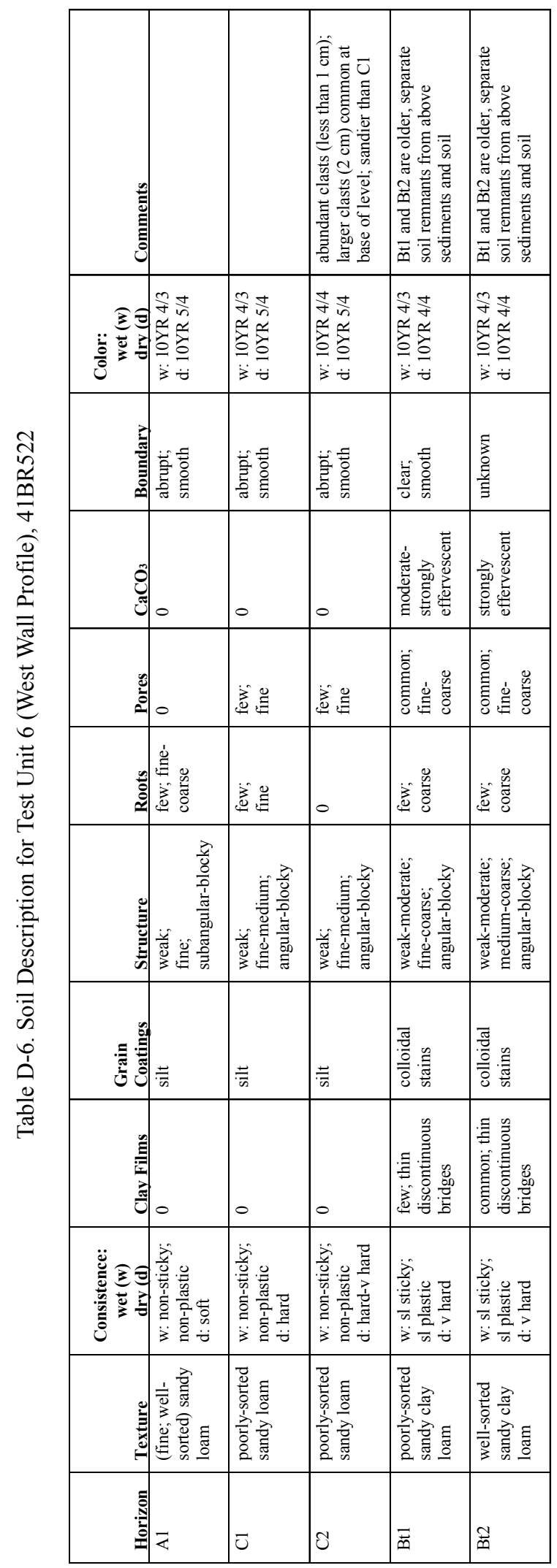


sedimentary deposits rest on top of two Bt horizons. There is no carbonate in the $\mathrm{C}$ and $\mathrm{A}$ horizons. Both $\mathrm{Bt}$ soils exhibit moderate-strong effervescence. These argillic soils have more robust clay films and contain more $\mathrm{CaCO}_{3}$ than the $\mathrm{Bt}$ horizon evident underneath the midden deposit. Bt1 contains more clasts than Bt2. Both Bt horizons are clearly older than the recent $\mathrm{C}-\mathrm{A}$ units above them. The lack of an unconformity between the $\mathrm{C}$ and $\mathrm{Bt}$ horizons suggest that there may be several small erosional episodes and depositional events that have removed portions of the upper $\mathrm{Bt}$ prior to the deposition of the $\mathrm{C}$ horizons. This is consistent with colluvial deposition (Waters 1992:155-156). The clay films and carbonate in these Bt soils contrast with the lack of clay films and carbonate in the soil underneath the midden fill. An unknown amount of paleosol has apparently been removed from this location and the remnant Bt horizons are not genetically related to the thin A horizon and unmodified $\mathrm{C}$ horizons that have experienced minimal pedogenesis. The profile of TU 3 and TU 4 (Figure D-7) represents the southern end of the midden. This portion was described (Table D-7) because it was the only portion of the excavations that had been excavated to underlying soil at the time of this geoarchaeological investigation. Unlike the feature on 41BR392, the burned rock midden at 41BR522 exhibits significant evidence of its use as a roasting pit feature. There is no $\mathrm{CaCO}_{3}$ evident in the midden fill or the exposed underlying $\mathrm{Bt}$ soil. The entire midden fill is black to very dark gray $(10 \mathrm{YR} 2 / 1$, wet; $10 \mathrm{YR} 3 / 1$, dry). A single Montell dart point fragment, temporally assigned to the Late Archaic, was recovered from $30-40 \mathrm{~cm}$ in the midden fill.
The burned rock midden on 41BR522 shows clear evidence of a central pit and surrounding spoil from excavation of the contents of the pit (Figure 9-4). It appears to have been only minimally disturbed following use. Both the surface and subsurface definition of this feature are excellent. There is a small amount of colluvial and alluvial redeposition of rock from the midden on the southwestern (maximally $5 \mathrm{~m})$, southern $(4 \mathrm{~m})$, and especially southeastern sides $(6 \mathrm{~m})$ of the midden. The area containing artifacts adjacent to the feature is not extensive. These qualities provide no suggestion of multiple occupations of this location or frequent re-use of the midden. The feature profile contains clear structural evidence for a central pit. The base of the feature is deepest within TU 1 and the southern half of TU 2. A clear layer of larger rock was identified in the lowest portion of TUs 1 and 2 that appears to indicate the base of a roasting feature. An intrusive pit above this may represent a second use of this thermal feature, but is more likely to be colluvial infilling following opening of the thermal feature to retrieve its contents. This disturbance may simply be a krotovina that is associated with the center of the midden. The mounded burned rock is clearly accumulated on the south side of the feature. The central pit and burned rock spoil is evident in both walls of the excavation (Figure 9-4). On the surface, this earth oven feature has a very welldefined central surface depression that is associated with the central pit. The surrounding ring of rock appears both at the surface and in profile to be the rock that has been dragged from the feature. There is no evidence of overprinting or reconfiguration that would suggest multiple uses of this

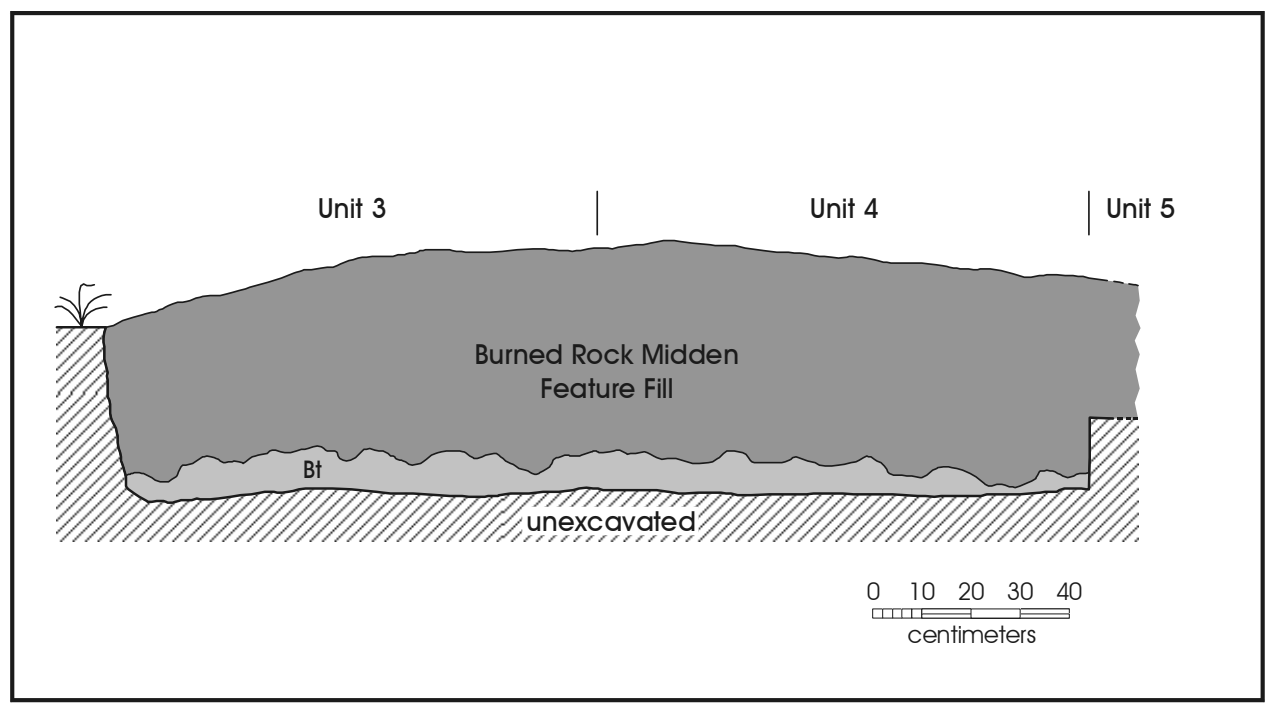

Figure D-7. Soil profile of Test Units 3 and 4 (west wall) at 41 BR522. 


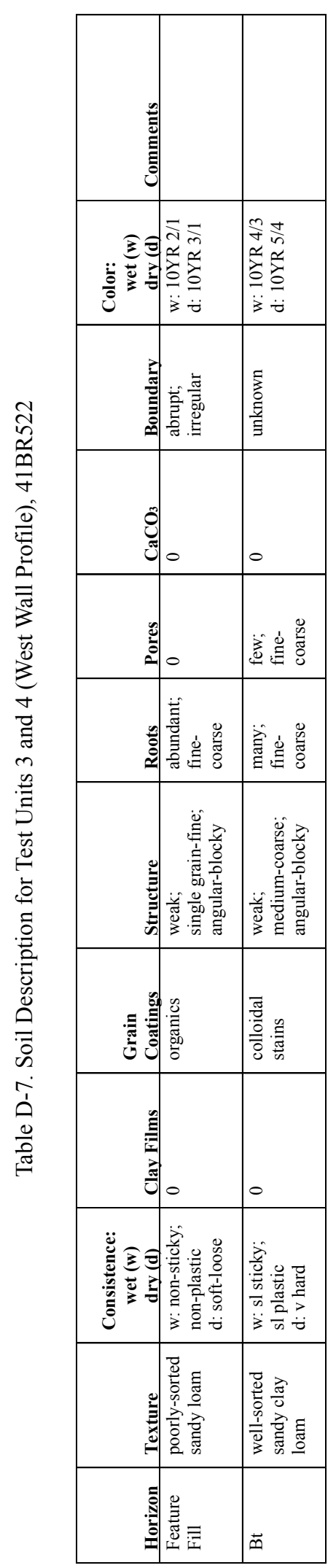


feature. The clear definition of the feature morphology is strong evidence for a single use episode. If this feature was used more than once, the absence of apparent secondary distinct pit and spoil structure in this profile indicates it could not have been used for more than a very small number of additional episodes. As noted previously, the feature on this site exhibits unambiguous morphology of a central depression and surrounding ring of fire-cracked rock (Figure 9-4). The central depression is maximally $70 \mathrm{~cm}$ thick, although the upper $10-15 \mathrm{~cm}$ is colluvial infilling of this area of the feature from the surrounding upslope margin. This portion of the feature is also thicker because it represents the pit with maximum subsurface excavation. The ring of rock exhibits higher surface relief but is thinner than the center. On the southern side of the midden, excavation exposed approximately $40-45 \mathrm{~cm}$ of rock and charcoal stained fill above the intact soil. This side has probably been subject to colluvial erosion of some of the feature. The feature on 41BR392 has a much thicker deposit of rock and charcoal stained sediment $(80-93 \mathrm{~cm})$. The surface morphology, profiles in the feature, and comparison with 41BR392 all suggest that this feature preserves excellent information about the construction and retrieval of contents from the final, and perhaps only use event.

The profile of TU 3 and TU 4 at the southern margin of the burned rock midden has only a very small amount of intact older soil exposed underneath the feature fill in the excavations. The Bt soil underlying the feature fill is a wellsorted sandy clay loam that is similar to Bt1 in TU 6 . However, this soil in TU 3 and TU 4 does not have as a high clay content or any effervescent reaction to $\mathrm{HCl}$ as does $\mathrm{Bt1}$ in TU 6. This Bt horizon is probably a higher portion of the ancient soil profile that has been eroded from the lower setting at TU 6. The Bt in TU 3 and TU 4 is approximately $75-95 \mathrm{~cm}$ higher than the top of the Bt1 in TU 6 .

\section{Conclusions}

\section{BR392}

Examination of the portion of this site containing the burned rock midden identified a relatively intact terrace surface in TU 4 that appears to be associated with the archaeological occupation. Concentrations of lithics and clasts that are probably derived from the feature were concentrated approximately $10-30 \mathrm{~cm}$ below the modern ground surface. This inference must be qualified by the fact that investigation was confined to the profile of a single 1-x-1-m unit excavated to a depth of $60 \mathrm{~cm}$. The burned rock midden does not appear to contain structural integrity that would make identification of its morphology unambiguous. The midden at this site may represent more than one use event. It is possible that there has been significant disturbance of the feature from the historic occupation. Investigations of other portions of this site away from the midden have the highest potential to offer productive information about the prehistoric occupation of 41BR392.

\section{BR500}

This is a small remnant of a site that has been significantly impacted by agricultural activities. The deposits are apparently quite shallow. Clasts at the base of the Bt1 horizon in TUs 1 and 3 suggest that an ancient land surface is only $15-20 \mathrm{~cm}$ below the modern surface. A comparable accumulation of clasts are present in the base of the A2 horizon in TU 4, approximately $10 \mathrm{~cm}$ below the modern ground surface. Archaeological artifacts were most common in the $\mathrm{A} 2$ and Bt1 horizons (approximately $0-25 \mathrm{cmbs}$ ) of TU 4. Examination of the possible feature in TUs 1-3 does not suggest it contains significant integrity. The association of fire-cracked rock and natural clasts indicates this is likely an accumulation of rock that is not cultural. This site had a very high density of recovered lithics. Although it may be possible to recover a large sample of lithics from 41BR500, this site has a low potential to address site structural questions. The demonstrated movement or degradation of the elements in the possible feature and extensive vertical dispersal of artifacts indicates significant post-depositional alterations of the archaeological deposit. This may be due to the destruction of much of the site on the flat floodplain and preservation only at the margin of the colluvial slope on the western side of 41BR500. This area is expected to have been subject to the greatest amount of complex taphonomic events through slopewash and erosion from upland runoff.

\section{BR522}

This site exhibited the most integrity of its subsurface deposits. This is especially apparent in the midden feature. Both its surface form and the profiles demonstrate a clear central pit and associated ring of spoil fire-cracked rock from emptying the roasting feature. It appears to have a strong likelihood to represent a single occupational event and use of the burned rock midden. This feature offers a significant opportunity for more detailed examination of feature use in the Camp Bowie area. Concerted sampling for charred macrobotanical remains, phytoliths, and starches 
could produce important information in combination with the structural integrity of this feature. Only one test unit, TU 6, was excavated away from the midden. TU 6 contained recent colluvial sediments and a very thin, young A horizon. The concentration of clasts and artifacts within the $\mathrm{C} 2$ and Bt1 soils may indicate a post-occupational association of artifacts related to the recent deposition of the $\mathrm{C}$ horizons. Evaluation of other portions of the level floodplain margin near the feature could identify areas that are more intact. If this site represents a short-term use focused on this one feature, there may be a minimal archaeological record of activities from such a short time investment. Additional excavation of areas surrounding the burned rock midden may encounter evidence of auxiliary activities performed while waiting for completion of roasting activities. Even negative results from examining the margins of this feature would be valuable information. 


\section{References Cited}

Clower, D. F.

1980 Soil Survey of Brown and Mills Counties, Texas. United States Department of Agriculture, Soil Conservation Service and the Texas Agricultural Experimental Station.

Greaves, R. D.

2002 Archaeological Survey of Three Land Parcels and Shovel Testing of Four Sites at Camp Bowie, Brown County, Texas. Archaeological Survey Report, No. 328. Center for Archaeological Research, The University of Texas at San Antonio.

Mauldin, R. P., and C. J. Broehm

2001 An Archaeological survey of Camp Bowie, Brown County, Texas. Archaeological Survey Report, No. 319. Center for Archaeological Research, The University of Texas at San Antonio.

Soil Survey Staff

1975 Soil Taxonomy: A Basic System of Classification for Making and Interpreting Soil Surveys. Agricultural Handbook No. 436. Soil Conservation Service, U.S. Department of Agriculture. U.S. Government Printing Office, Washington, D.C.

1993 Soil Survey Manual. U.S. Department of Agriculture Handbook No. 18. U.S. Department of Agriculture. U.S. Government Printing Office, Washington, D.C.

Waters, M. R.

1992 Principles of Geoarchaeology: A North American Perspective. University of Arizona Press, Tucson.

Wormser, A. J., and S. Sullo-Prewitt.

2001 Cultural Resources Inventory of Camp Bowie, Brownwood, Texas. Archaeological Survey Report, No. 317. Center for Archaeological Research, The University of Texas at San Antonio. 